\title{
De Overijsselse arbeidsmarkt naar opleiding en beroep 2003-2008
}

Citation for published version (APA):

Borghans, L., Golsteyn, B. H. H., Heijke, J. A. M., \& Kriechel, B. (2005). De Overijsselse arbeidsmarkt naar opleiding en beroep 2003-2008. ROA. ROA Reports No. 1 https://doi.org/10.26481/umarep.2005001

Document status and date:

Published: 01/01/2005

DOI:

10.26481/umarep.2005001

Document Version:

Publisher's PDF, also known as Version of record

\section{Please check the document version of this publication:}

- A submitted manuscript is the version of the article upon submission and before peer-review. There can be important differences between the submitted version and the official published version of record.

People interested in the research are advised to contact the author for the final version of the publication, or visit the DOI to the publisher's website.

- The final author version and the galley proof are versions of the publication after peer review.

- The final published version features the final layout of the paper including the volume, issue and page numbers.

Link to publication

\footnotetext{
General rights rights.

- You may freely distribute the URL identifying the publication in the public portal. please follow below link for the End User Agreement:

www.umlib.nl/taverne-license

Take down policy

If you believe that this document breaches copyright please contact us at:

repository@maastrichtuniversity.nl

providing details and we will investigate your claim.
}

Copyright and moral rights for the publications made accessible in the public portal are retained by the authors and/or other copyright owners and it is a condition of accessing publications that users recognise and abide by the legal requirements associated with these

- Users may download and print one copy of any publication from the public portal for the purpose of private study or research.

- You may not further distribute the material or use it for any profit-making activity or commercial gain

If the publication is distributed under the terms of Article $25 \mathrm{fa}$ of the Dutch Copyright Act, indicated by the "Taverne" license above, 


\section{BATS-II

De Overijsselse arbeidsmarkt

naar opleiding en beroep 2003-2008
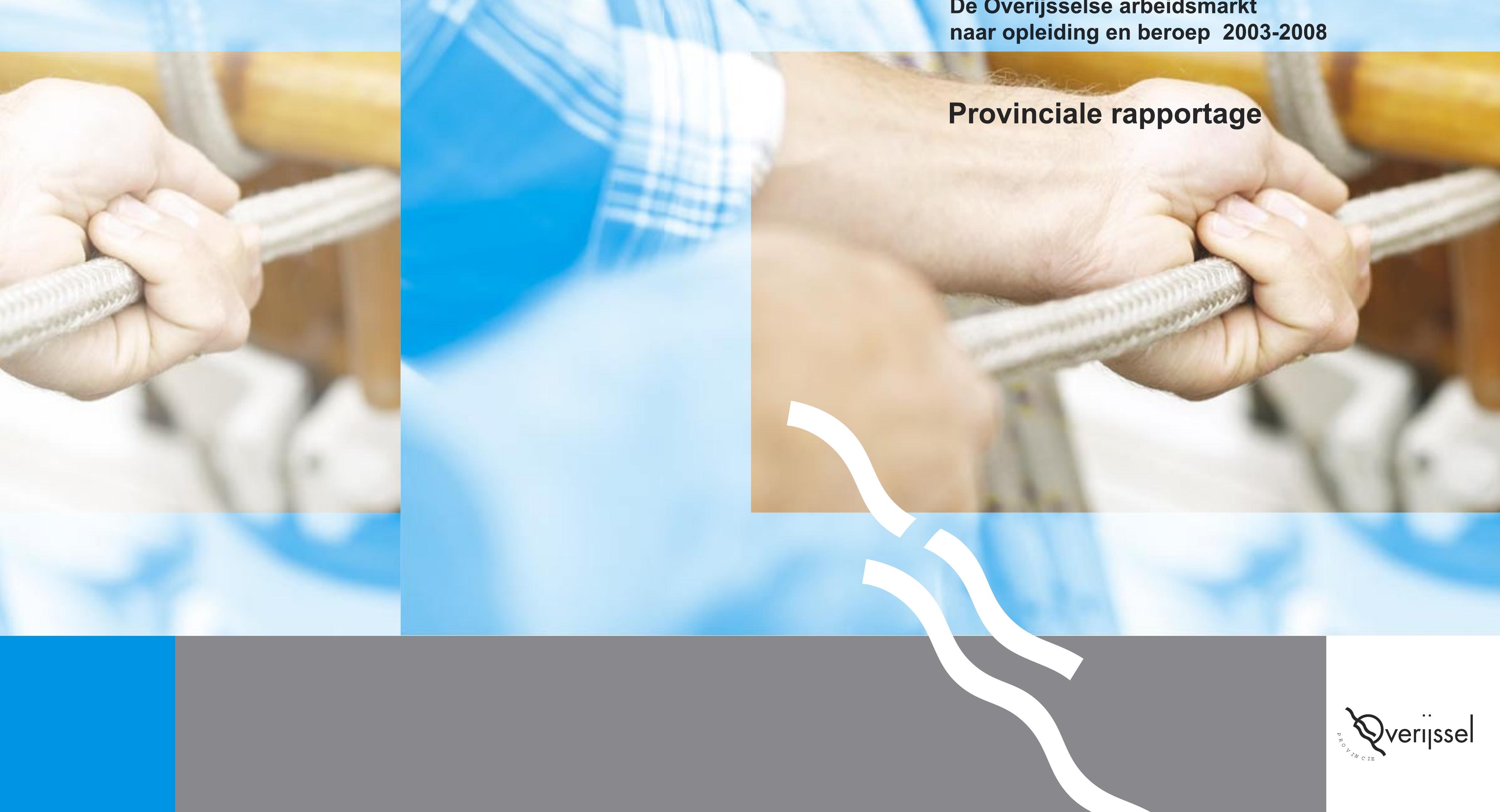


\title{
Ratio II
}

De Overijsselse arbeidsmarkt naar opleiding en beroep 2003-2008

\author{
ROA-R-2005/1
}
L. Borghans
B. Golsteyn
H. Heijke
M. Hensen
B. Kriechel

\section{Researchcentrum voor Onderwijs en Arbeidsmarkt \\ Faculteit der Economische Wetenschappen en Bedrijfskunde Universiteit Maastricht}

Maastricht, februari 2005 
Niets uit deze uitgave mag worden verveelvoudigd en/of openbaar gemaakt door middel van druk, fotokopie, microfilm, of op welke wijze ook, zonder voorafgaande schriftelijke toestemming van de directeur van het Researchcentrum voor Onderwijs en Arbeidsmarkt. In geval van overname van het datamateriaal moet telkens als bron worden vermeld: "Researchcentrum voor Onderwijs en Arbeidsmarkt" of "ROA". Van publicaties waarin gebruik wordt gemaakt van gegevens uit dit rapport ontvangen wij gaarne een exemplaar.

Hoewel de grootst mogelijke zorg is besteed aan de inhoud van dit rapport, kan het ROA in generlei opzicht verantwoordelijkheid op zich nemen voor eventuele onvolledigheden of onjuistheden.

ISBN 90-5321-000-8

Sec05.009.doc 


\section{Inhoud}

Bladzijde

Voorwoord

Samenvatting van de resultaten iii

1 Werkgelegenheid en vervangingsvraag 1

1.1 Inleiding 1

1.2 De opbouw van de werkgelegenheid naar sector, beroep en
opleiding

1.3 Uitbreidingsvraag: Trends in de werkgelegenheid in sectoren 5

1.4 Vervangingsvraag: Demografische ontwikkeling en $\begin{array}{ll}\text { arbeidsmarktparticipatie } & 8\end{array}$

$\begin{array}{ll}1.5 \text { Conclusie } & 10\end{array}$

2 Deelname aan onderwijs en arbeidsmarktinstroom 11

2.1 Inleiding 11

2.2 Het aantal gediplomeerden 12

$\begin{array}{ll}2.3 \text { Het aantal leerlingen } & 14\end{array}$

$\begin{array}{ll}2.4 & \text { Aanbod van schoolverlaters } \\ 2.5 & 17\end{array}$

$\begin{array}{ll}2.5 \text { Conclusie } & 18\end{array}$

3 De Overijsselse arbeidsmarkt op middellange termijn 21

$\begin{array}{ll}3.1 & \text { Inleiding } \\ 3.2 & 22\end{array}$

$\begin{array}{ll}3.2 \text { Vacatures } & 22\end{array}$

$\begin{array}{ll}3.3 & \text { Uitbreidingsvraag } \\ 3.4 & 23\end{array}$

$\begin{array}{ll}3.4 & \text { Vervangingsvraag } \\ 3.5 & 29\end{array}$

$\begin{array}{lll}3.5 & \text { Baanopeningen } & 32\end{array}$

4 Verwachte knelpunten en perspectieven op de arbeidsmarkt voor $\begin{array}{ll}\text { schoolverlaters } & 39\end{array}$

$\begin{array}{ll}4.1 & \text { Inleiding } \\ 4.2 & \end{array}$

4.2 De arbeidsmarktperspectieven voor schoolverlaters 41

4.3 Knelpunten in de personeelsvoorziening voor werkgevers 43

4.4 Uitwijk- en substitutiemogelijkheden op de arbeidsmarkt 46

$\begin{array}{lll}4.5 & \text { Conclusie } & 50\end{array}$

5 De invloed van de conjunctuur op de prognose 51

5.1 Inleiding 51

5.2 Sectorale trends 51

5.3 Sectorale ontwikkeling van de beroepsbevolking in Overijssel 53

5.4 Vier Scenario's $\quad 55$

5.5 Conclusie 57 
6 De onderkant van de arbeidsmarkt 61

$\begin{array}{ll}6.1 \text { Inleiding } & 61\end{array}$

6.2 Afbakening van de onderkant 62

$\begin{array}{ll}6.3 \text { Het economische probleem } & 62\end{array}$

6.4 Probleemgroepen in Overijssel en Nederland 67

6.5 Invloed conjunctuur op de werkgelegenheid aan de onderkant 72

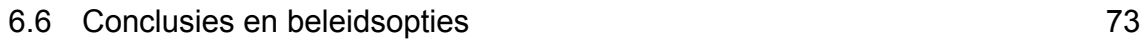

7 Geografische mobiliteit en werkgelegenheid $\quad 75$

$\begin{array}{ll}7.1 & \text { Inleiding } \\ 75\end{array}$

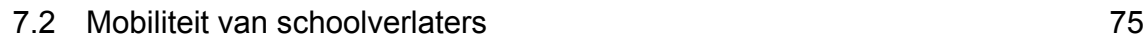

$\begin{array}{ll}7.3 \text { Ontwikkeling in de mobiliteit 1991-2001 } & 79\end{array}$

7.4 Geografische mobiliteit en knelpunten in de personeelsvoorziening 86

$\begin{array}{lll}7.5 \text { Conclusies } & 87\end{array}$

$\begin{array}{lr}\text { Verklarende woordenlijst } & 89\end{array}$ 


\section{Voorwoord}

De economie in Nederland is continu in beweging. Dit heeft directe gevolgen voor de ontwikkeling van de werkgelegenheid in de regio. Voldoende reden om de vinger aan de pols te houden en de nieuwe RATIO-gegevens als basis te gebruiken voor de ontwikkeling en uitvoering van het regionaal arbeidsmarktbeleid.

Als verantwoordelijk bestuurder voor het provinciaal arbeidsmarktbeleid presenteer ik hierbij het nieuwe rapport "De Overijsselse arbeidsmarkt 2003-2008, naar opleiding en beroep", uitgevoerd door het Researchcentrum voor Onderwijs en Arbeidsmarkt (ROA) van de Universiteit Maastricht. Het rapport biedt een geactualiseerde verkenning van de aansluiting onderwijs en arbeidsmarkt in Overijssel en geeft een gedifferentieerd beeld van de toekomstige Overijsselse arbeidsmarkt naar opleiding en beroep. Daarnaast geeft het inzicht in de verwachte ontwikkelingen binnen bedrijfssectoren en de daarvoor nodige kwalificaties van de (potentiële) beroepsbevolking. Extra aandacht wordt in het rapport besteed aan de onderkant van de arbeidsmarkt.

Het provinciebrede rapport geeft in samenhang met de regiorapportages van de Regionale Platforms Arbeidsmarktbeleid (RPA's) Twente en IJssel-Vecht een compleet en goed inzicht in de regionale arbeidsmarkten van Overijssel.

Ik nodig de samenwerkingspartners van harte uit aan de slag te gaan met deze schat aan informatie. In het bijzonder biedt dit rapport een stevige uitdaging voor het verbeteren van de aansluiting tussen vraag en aanbod op de Overijsselse arbeidsmarkt. Het is zaak kansen en mogelijkheden te benutten en samen te werken aan een goed functionerende regionale arbeidsmarkt, die bestaande werkgelegenheid behoudt en nieuwe creëert.

Graag wil ik met de betrokken partners optrekken om samen onze regionale arbeidsmarkt aantrekkelijk te maken voor alle Overijsselse burgers.

Carry Abbenhues

Gedeputeerde voor Economie en Innovatie van de Provincie Overijssel 



\title{
Samenvatting van de resultaten
}

\author{
Ontwikkeling van de werkgelegenheid gematigd positief
}

- De toekomstige ontwikkeling van de werkgelegenheid is gematigd positief. Over de periode van 2003 - 2008 wordt een groei van $4 \%$ voor de totale werkgelegenheid voorspeld (zie hoofdstuk 3.3).

- De groei van de werkgelegenheid zal vooral ten goede komen aan de hoger opgeleide werknemers. Ook werknemers met een MBO opleiding kunnen van de groei profiteren. Lager geschoolde werknemers zullen echter een krimp in de werkgelegenheid ervaren (zie hoofdstuk 1.3).

- Over alle sectoren is een ontwikkeling te zien naar hoger opgeleide werknemers (tabel 1.4), terwijl voor sommige sectoren tevens een uitbreiding van de elementaire en lagere beroepen voorspeld wordt (tabel 1.3). Dit wijst enerzijds op een opwaardering van tot nog toe als lager beschouwde beroepen en anderzijds op een algemene vraag naar meer scholing (zie hoofdstuk 1.3).

- Grote bedrijfssectoren met veel werkgelegenheid zijn in Overijssel: Industrie, Handel en reparatie, Horeca en zakelijke dienstverlening, Kwartaire diensten en de sector Overheid en onderwijs. Grote beroepsgroepen zijn de Technische, ambachts- en industrieberoepen, de Economisch-administratieve beroepen, en de Verzorgende en dienstverlenende beroepen (zie hoofdstuk 1.2).

- Van de grote sectoren vertoond de industrie een daling van de werkgelegenheid, terwijl de andere grote sectoren groeien. Door het krimpen van de werkgelegenheid in de industrie wordt ook een daling onder de Technische, ambachts- en industrieberoepen verwacht, terwijl in samenhang met de groei van de andere sectoren de Economisch-administratieve beroepen licht, en de Verzorgende en dienstverlenende beroepen sterk groeien. Het meeste profiteren de Informatica beroepen, de Pedagogische beroepen en de (Para-)medische beroepen van de positieve ontwikkeling van de werkgelegenheid (zie hoofdstuk 3.3).

Vervangingsvraag voor Overijssel lager dan voor Nederland

- Dat bepaalde opleidingen met een stagnerende of krimpende werkgelegenheidsontwikkeling te maken hebben betekent niet automatisch dat de schoolverlaters van deze opleidingen geen werk zullen kunnen vinden. Hiervoor moet naar de baanopeningen gekeken worden, d.w.z de som van werkgelegenheidsgroei en ontstane vervangingsbehoefte doordat mensen 
stoppen met werken of met pensioen gaan, of een andere baan aannemen. Als men naar de toekomstige baanopeningen kijkt is te zien dat de nieuwe banen voor lager opgeleiden vooral hier vandaan komen, dus vooral de vervangingsvraag als bron hebben (zie hoofdstuk 3.4).

- De vervangingsvraag hangt in belangrijke mate samen met de participatie op de arbeidsmarkt en de leeftijdsopbouw van de beroepsbevolking. In Overijssel is de participatie iets lager dan in Nederland, maar de beroepsbevolking is wel jonger. Hierdoor komt het tot een licht lagere vervangingsvraag als percentage van de werkenden dan landelijk (zie hoofdstuk 3.4).

- De toekomstige baanopeningen, de som dus van uitbreidingsvraag en vervangingsvraag, zijn als percentage van de werkenden hoger dan landelijk is voorspeld. Dit komt door de hogere uitbreidingsvraag (zie hoofdstuk 3.5).

\section{Schoolverlaters hebben redelijk goed perspectief}

- De instroom van schoolverlaters is vooral met betrekking tot het lager en middelbaar onderwijs een belangrijke bron van nieuwe werknemers in de provincie. In Overijssel zal het aantal VMBO'ers licht dalen, terwijl het aantal MBO'ers redelijk stabiel blijft. Bij de toekomstige instroom vanuit het beroepsonderwijs valt een stijging van VMBO Economie en MBO Dienstverlening en gezondheidszorg te verwachten, terwijl MBO Natuur en techniek achter blijft (zie hoofdstuk 2).

- Confrontatie van de baanopeningen met de instroom vanuit het onderwijs geeft een inschatting van de perspectieven voor het vinden van een baan door schoolverlaters (met als tegenhanger: knelpunten voor werkgevers om personeel aan te trekken). Uit de gemaakte confrontaties blijkt dat bijvoorbeeld MBO Natuur en techniek goede arbeidsmarktperspectieven heeft en dat deze voor MBO Economie slechts redelijk zijn. MBO Economie heeft namelijk een tamelijk grote instroom vanuit de scholen (zie hoofdstuk 4.2).

- Op het niveau van beroepen kunnen werkgevers knelpunten verwachten onder de Pedagogische, Culturele, Informatica, en de Openbare orde en veiligheidsberoepen (zie hoofdstuk 4.3).

- Knelpunten voor werkgevers maar ook slechte vooruitzichten voor schoolverlaters kunnen ertoe leiden dat schoolverlaters alternatieve, meer of minder verwante, beroepen kiezen. Naarmate de opleiding meer uitwijkmogelijkheden toelaat kunnen zo de knelpunten opgelost worden. Ook werkgevers kunnen bij bepaalde beroepen, die algemenere competenties vereisen, in geval van knelpunten personeel met alternatieve opleidingen aantrekken (zie figuur 4.1 en 4.2 in hoofdstuk 4.4). 
Scenario analyse toont kwetsbaarheid van laag opgeleiden

- De lagere beroepen en vooral ook de middelbare beroepen worden getroffen door tegenvallende groei. Terwijl zij flink groeien in een voorspoedige economische omgeving, krimpen zij ook net zo hard bij tegenvallende economische groei. De vervulling van beroepen door nieuwe arbeidskrachten gaat bij tegenvallende groei ten koste van de laagst opgeleiden. Hoe slechter de economische situatie hoe sterker de krimp onder de werknemers met Basisonderwijs of VMBO. Werkgevers proberen vooral bij tegenvallende economische ontwikkeling hoger en middelbaar opgeleide werknemers in dienst te houden, ook al zitten zij op functies die ook door lager opgeleiden vervuld kunnen worden (zie hoofdstuk 5 en 6.5).

- Uit de uitgevoerde scenario-analyse blijkt dat bij sterke economische groei en bijbehorende werkgelegenheidsgroei het met name tot knelpunten bij het aantrekken van hoger opgeleiden zal komen (zie hoofdstuk 5, tabel 5.3).

- $\quad$ Groepen die problemen hebben op de arbeidsmarkt betreffen vooral laag opgeleide ouderen die geen langdurige arbeidsverhouding hebben, of laag opgeleide jongeren en voortijdig schoolverlaters. Gezien de trend op de arbeidsmarkt naar middelbaar of hoger opgeleiden moet het belang van scholing voor deze groepen worden benadrukt. Hierdoor worden zij ook minder kwetsbaar voor conjuncturele invloeden op de arbeidsmarkt (zie hoofdstuk 6).

\section{Pendel biedt geen oplossing voor knelpunten}

- $\quad$ Bewoners uit Overijssel blijken steeds verder te reizen naar hun werk, maar omgekeerd komen de mensen die in de provincie werken ook van steeds verder. Veelal wordt gedacht dat ook de toegenomen congestie een grote invloed heeft op de reistijden. Het effect hiervan op de reistijden in Overijssel blijkt echter zeer gering te zijn (zie hoofdstuk 7.1).

- Knelpunten in de personeelsvoorziening kunnen slechts in zeer beperkte mate verlicht worden door pendel of verhuizing (zie hoofdstuk 7.3). 



\section{Werkgelegenheid en vervangingsvraag}

RATIO I stond in het teken van een veranderende arbeidsmarkt. Er was sprake van tegenvallende werkgelegenheidsgroei en oplopende werkloosheid. Om de vinger aan de pols te kunnen houden, was het wenselijk een update te maken van RATIO I. Dit zou tevens de gelegenheid scheppen om enkele onderwerpen te belichten die eerder niet aan bod kwamen. Voor de samenstelling van deze update, RATIO II, kan gebruik worden gemaakt van nieuwe landelijke prognoses van de arbeidsmarktontwikkeling op de middellange termijn van ROA en van nieuwe prognoses van de sectorale werkgelegenheidsontwikkeling op landelijk niveau van CPB en voor Overijssel van Etil.

De rapportage RATIO I omvatte tevens een statistische bijlage. Deze bijlage is voor RATIO II tevens omgezet naar een gedigitaliseerd Arbeidsmarkt Informatie Systeem (AiS). Dit maakt het makkelijker om met behulp van RATIO doelgericht en interactief vragen te beantwoorden. Het AiS laat immers toe dat de gebruiker zelf de gewenste tabellen voor beroepsgroepen, beroepssectoren, onderwijssectoren of -klassen aanmaakt. Men kan zich richten op het detail niveau van specifieke beroepen of men kan een aanpak op een hoger niveau volgen door bepaalde sectoren of beroepsgroepen als invalshoek te kiezen. Het AiS heeft dus een duidelijk toegevoegde waarde.

Dit hoofdstuk heeft betrekking op de vraagzijde van de Overijsselse arbeidsmarkt. De ontwikkelingen worden geschetst die de achtergrond vormen van de prognoses van de vraag naar arbeid, die meer in detail worden besproken in hoofdstuk 3. In het bijzonder wordt in dit hoofdstuk ingegaan op de structuur en ontwikkeling van de uitbreidingsvraag (de werkgelegenheid) en van de vervangingsvraag. Met deze achtergrondgegevens wordt beoogd een indruk te geven van de factoren die bepalend zijn voor de ontwikkeling van beide bestanddelen van de arbeidsvraag en welke gevolgen een alternatief verloop van deze factoren hiervoor zouden kunnen hebben. In hoofdstuk 2 komen de ontwikkelingen aan de orde die de achtergrond vormen voor de prognoses van het aanbod van arbeid.

\subsection{Inleiding}

In dit hoofdstuk worden de ontwikkelingen geschetst die de achtergrond vormen voor de prognoses van de vraag naar arbeid in Overijssel, die meer in detail zullen worden belicht in hoofdstuk 3. In paragraaf 1.2 wordt een beschrijving gegeven van de voor de uitbreidingsvraag belangrijke sectorale samenstelling van de werkgelegenheid en de opbouw van de werkgelegenheid naar beroepen en opleidingen. Ook wordt ingegaan op de conjuncturele gevoeligheid van de sectorale werkgelegenheid. In paragraaf 1.3 worden de trends geanalyseerd van de werkgelegenheid binnen sectoren. Een prognose van deze trends ligt ten grondslag aan de uitbreidingsvraagprognose. Tenslotte wordt in paragraaf 1.4 de belangrijke achterliggende 
factoren van de vervangingsvraag belicht. Het gaat hier om de ontwikkeling van de arbeidsmarktparticipatie en de demografische opbouw van de beroepsbevolking.

\subsection{De opbouw van de werkgelegenheid naar sector, beroep en opleiding}

De sectorale werkgelegenheidsdynamiek vormt een belangrijke factor voor de ontwikkeling van de werkgelegenheid in beroepen en opleidingen. In figuur 1.1 worden de aandelen weergegeven van de sectoren in de totale Overijsselse werkgelegenheid. Hierin is duidelijk te zien dat het gros van de werkgelegenheid te vinden is in de Kwartaire Diensten, Horeca en zakelijke dienstverlening, Overheid en onderwijs, en Handel en reparatie. Kleinere sectoren in Overijssel zijn Energie, Banken verzekeringswezen, Chemie en de Voedingsindustrie.

Figuur 1.1

Sectorale verdeling van de werkgelegenheid

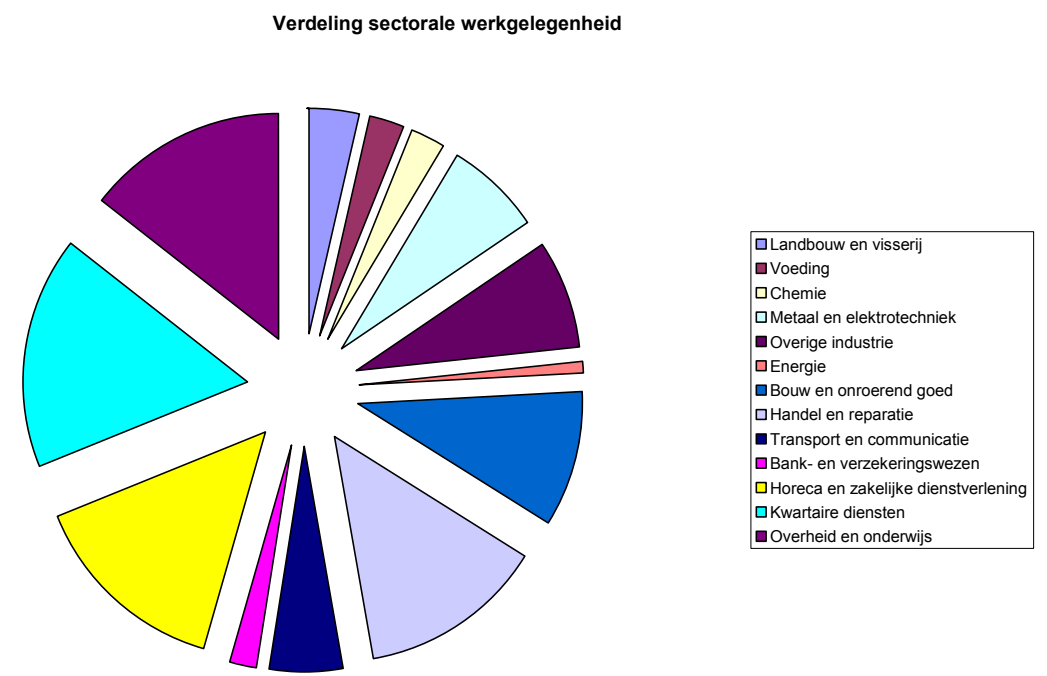

Bron: CBS (EBB 2002)

Ten opzichte van Nederland is de werkgelegenheid hoger in Metaal en elektrotechniek, Overige industrie, Energie en Landbouw. De aandelen van de sectoren Transport en communicatie, Bank- en verzekeringswezen en Horeca en zakelijke dienstverlening zijn daarentegen in Overijssel kleiner dan hun aandeel in Nederland.

Binnen de sectoren zijn de werknemers in beroepen in te delen. De beroepensamenstelling van de sectorale werkgelegenheid vormt een belangrijke achterliggende factor voor de prognoses van de uitbreidingsvraag, met name naar opleiding. Veel beroepen zijn in meer dan één sector terug te vinden. Zo kan een accountant, een beroep uit de grote beroepsgroep Economisch-administratieve be- 
roepen, bijvoorbeeld werkzaam zijn in de sector Bank- en verzekeringswezen maar ook in bijvoorbeeld de sector Overheid en onderwijs. Grote beroepscategorieën zijn in Overijssel de Technische, ambachts- en industrieberoepen, de Economischadministratieve beroepen en de Verzorgende en dienstverlenende beroepen. Middelgrote beroepscategorieën omvatten in Overijssel de Pedagogische beroepen, de Transportberoepen zoals de Medische en paramedische beroepen. Culturele beroepen, Agrarische beroepen, Informatica beroepen, Sociaal-culturele beroepen en Openbare orde- en veiligheidsberoepen zijn getalsmatig kleinere beroepscategorieën in Overijssel. ${ }^{1}$

Figuur 1.2

Verdeling van de werkgelegenheid over beroepen

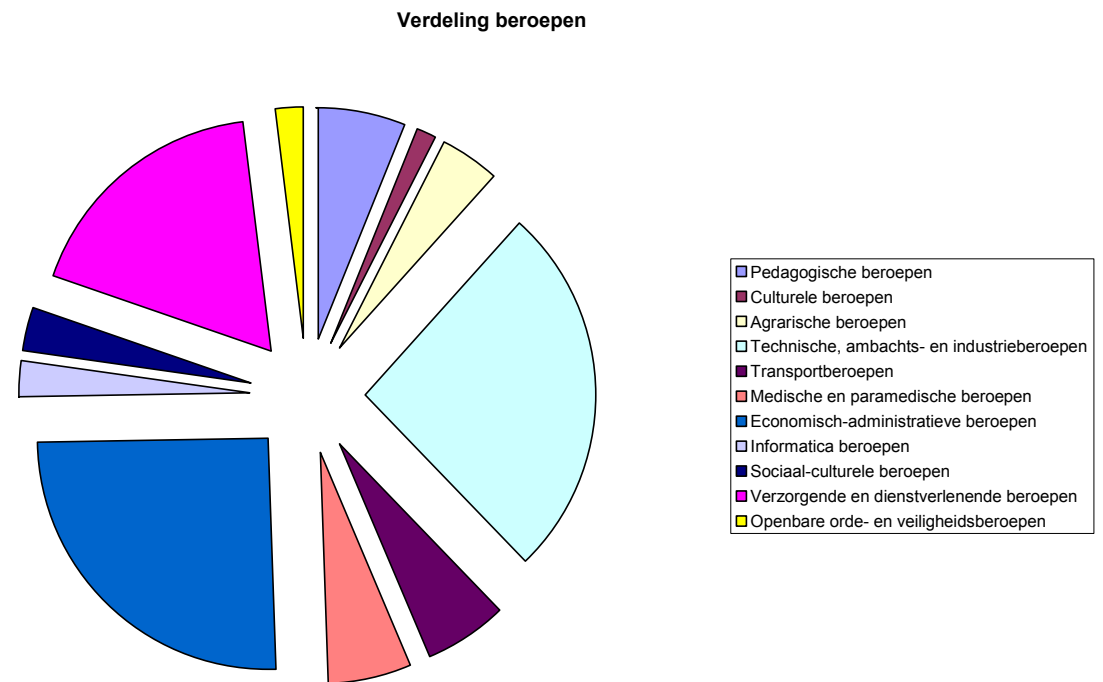

Bron: CBS (EBB 2002)

Vergelijkbaar met de beroepenindeling kunnen werknemers ook naar hun behaalde opleiding ingedeeld worden. Dit is het andere basiselement van de uitbreidingsvraagprognoses, waarbij er overigens mee wordt rekening gehouden dat. werknemers met een bepaalde opleiding in verschillende beroepen terecht kunnen komen (zie ook hoofdstuk 4 waar de uitwijkmogelijkheden van beroepen en opleidingen beschreven worden). Grote opleidingscategorieën zijn bij het MBO te vinden: MBO Natuur- en techniek, MBO Dienstverlening en gezondheidszorg en MBO Economie. Middelgrote categorieën zijn Basisonderwijs, VMBO Theorie, VMBO Natuur- en Techniek en $\mathrm{HBO}$ Onderwijs en sociaal-cultureel.

1. Culturele beroepen omvatten onder meer de beroepen Tolken, vertalers en schrijvers, Grafische ontwerpers, Kunstenaars, en Journalisten, terwijl Sociaal-culturele beroepen vooral beroepen omvat uit de richting sociaal-wetenschappelijk en maatschappelijk werk. In de ROA-classificatiegids 2002, ROA-R-2002/3, zijn de onderliggende beroepen of opleidingen voor de beroeps- of opleidingscategorieën te vinden. 
Figuur 1.3

Verdeling van de werkgelegenheid over opleidingen

Verdeling opleidingen

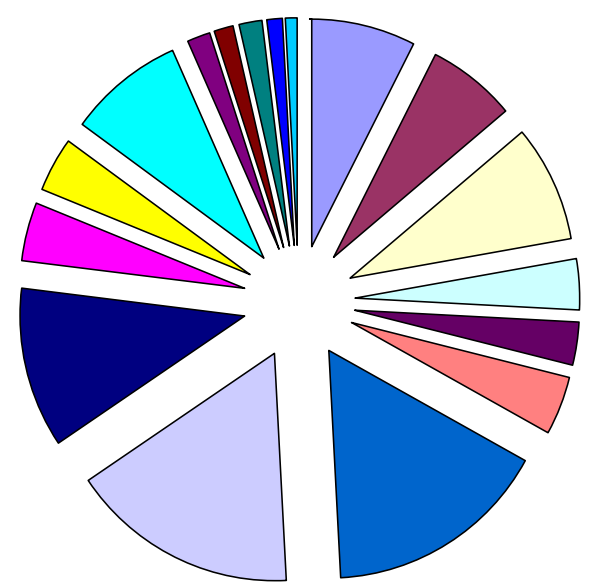

口Basisonderwijs

aVMBO Theorie

口VMBO Natuur en techniek

口VMBO Economie

- VMBO Verzorging

口HAVO/NWO

aBBO Natuur en techniek

口MBO Economie

MBO Dienstverlening en gezondheidszorg

HBO Natuur en techniek

DHBO Economie

DHBO Onderwijs en sociaal-cultureel

HBO Paramedisch

-WO Natuur en techniek

घWO Economie

wO Letteren en sociaal-culturee

口WO Medisch

Bron: CBS (EBB 2002)

De sectorale werkgelegenheid is over langere tijdsperioden gezien aan structurele veranderingen onderhevig. Zo neemt bijvoorbeeld het belang van de Landbouwsector gestaag af. Het aandeel van de Handel daarentegen groeit (zie ook 5.2 van dit rapport). Deze structurele veranderingen in de sectorale werkgelegenheid gaat gepaard met een cyclische werkgelegenheidsverandering, afhankelijk van de economische situatie op de kortte termijn. Dit wordt weergegeven in figuur 1.4 waar de economische groei in termen van de economische toegevoegde waarde in Overijssel (dikke zwarte lijn) is afgezet tegen de werkgelegenheidsontwikkeling in de onderscheiden sectoren. Opvallend is dat de Energiesector over vier van de zes beschouwde jaren een krimp vertoont. Landbouw groeit slechts in één jaar, namelijk in 2000, het jaar waarin Overijssel de sterkste economische groei vertoonde. Banken verzekeringswezen groeit duidelijk in tijden van hoogconjunctuur en krimpt in tijden van lage economische groei. Deze sectorale effecten werken door in de ontwikkeling van beroepen en opleidingen. Bij de arbeidsmarktprognoses voor Overijssel die in hoofdstuk 3 worden besproken, wordt als uitgangspunt genomen de landelijke sectorprognose die van een zich herstellende economie uitgaat. In hoofdstuk 5 onderzoeken wij de gevoeligheid van de Overijsselse arbeidsmarkt voor deze economische dynamiek op de korte termijn door een drietal scenario's toe te voegen met verschillende onderliggende groeicijfers. 
Figuur 1.4

Economische groei en procentuele verandering van de werkgelegenheid in Overijssel 19972002.

Overijssel groei en werkgelegenheidsverandering

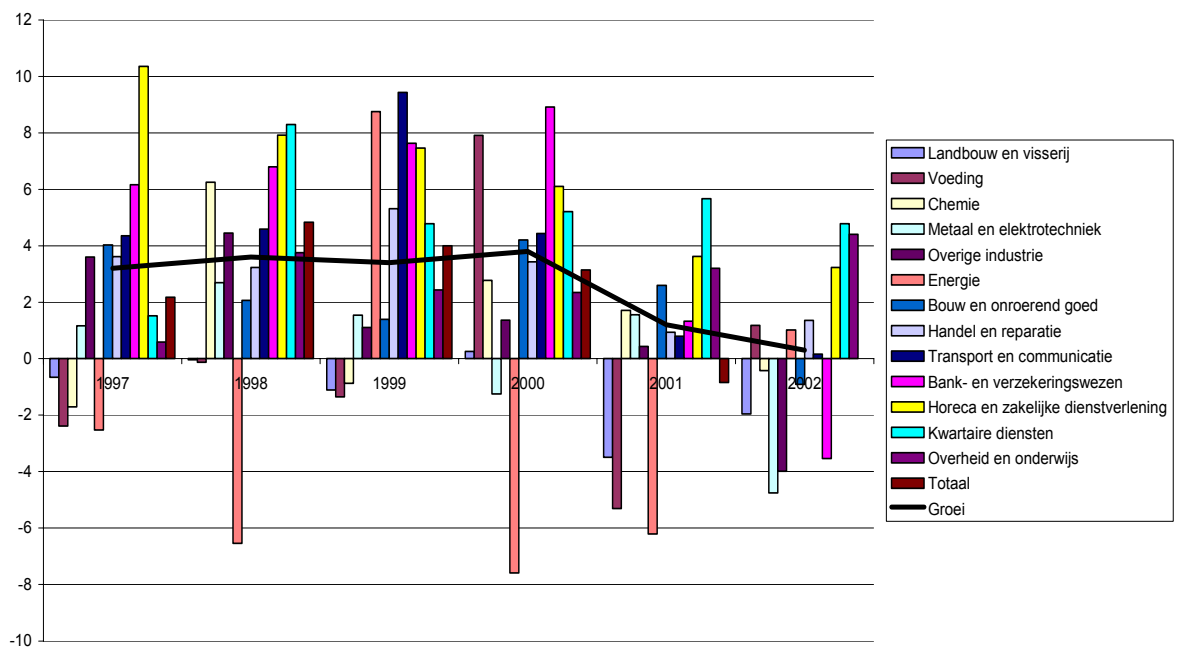

Bron: CBS, Etil

\subsection{Uitbreidingsvraag: Trends in de werkgelegenheid in sectoren}

Meer dan tweederde van de Overijsselse beroepsbevolking heeft een lagere of middelbare beroepsopleiding afgesloten. Deze groepen vormen de 'motor van de economie'. Wel is deze groep minder bereid om voor een baan te verhuizen, of ver te pendelen. Zij zijn dus regionaal gebonden. De hoger opgeleide groepen met HBO of wetenschappelijke opleiding daarentegen zien geheel Nederland als hun arbeidsmarkt (zie ook hoofdstuk 7). Daarom wordt bij de regionale prognoses meer aandacht aan de lagere en middelbaar opgeleide beroepsbevolking gegeven. Omdat zij minder gebruikmaken van regionale uitwijkmogelijkheden, worden zij meer beïnvloed door regionale werkgelegenheidsontwikkelingen en zal het regionaal werkgelegenheidsbeleid zich ook met name op deze groepen moeten richten.

In het gebruikte prognosemodel van de uitbreidingsvraag wordt de sectorale groei of krimp vertaald naar beroepen en vervolgens naar opleidingen. Hierdoor kan nagegaan worden hoe de algemene economische ontwikkeling uitpakt voor specifieke beroepsgroepen en opleidingen. Tabel 1.1 geeft voor de onderscheiden vijf opleidingsniveaus het aandeel weer in de Overijsselse werkgelegenheid en hun groeiprognose over de komende vijfjarenperiode. Meer dan tweederde van de werkgelegenheid wordt door VMBO of MBO opgeleide krachten vervuld. Hoger opgeleide werknemers met $\mathrm{HBO}$ nemen $18 \%$ en met WO slechts $5 \%$ van de werkgelegenheid voor hun rekening. Interessant is wel dat op de middellange termijn een duidelijke 
verschuiving naar hoger opgeleide arbeidskrachten wordt voorspeld. ${ }^{2}$ Terwijl Basisonderwijs en in mindere mate VMBO duidelijk krimpen, groeit de werkgelegenheid van de middelbare en hoger opgeleide beroepsbevolking.

Tabel 1.1

Werkgelegenheid onderwijscategorieën, aandeel 2003 en groeiprognose 2003-2008, in procenten

Aandeel Groeiprognose

$\begin{array}{lrr}\text { Basisonderwijs } & 7 & -20 \\ \text { VMBO } & 22 & -2 \\ \text { MBO } & 47 & 9 \\ \text { HBO } & 18 & 10 \\ \text { WO } & 5 & 14\end{array}$

Bron: ROA, CBS (EBB 2002)

Net als bij de opleidingen zijn de beroepen ook in categorieën van lager, middelbaar en hoger in te delen. Deze niveau-indeling sluit enigszins aan bij de driedeling in opleidingsniveaus. Zoals tabel 1.2 laat zien dragen de lagere en middelbare beroepen dragen bij aan meer dan driekwart van de werkgelegenheid in de provincie. Uit de weergegeven groeiprognose blijkt echter dat de relatie tussen opleidingsniveau en beroepenniveau niet als te direct gezien moet worden. Terwijl bij de opleidingen de groei hoger was bij de hogere niveaus is dit bij de beroepen niet het geval. Daarnaast is de werkgelegenheidsgroei van de lagere beroepen duidelijk hoger dan die van de middelbare beroepen. Hieruit kan men concluderen dat een deel van de middelbaar opgeleide werknemers in de lagere beroepen terecht komt. De bijzondere problematiek van de onderkant van de arbeidsmarkt wordt nader uitgewerkt in hoofdstuk 6 van dit rapport.

Tabel 1.2

Werkgelegenheid in beroepen, aandeel 2003 en groeiprognose 2003-2008, in procenten

Aandeel Groeiprognose

Elementaire en lagere beroepen

$34 \quad 6$

Middelbare beroepen

$42 \quad 1$

Hogere en wetenschappelijke beroepen

Bron: ROA, CBS (EBB 2002)

Tabel 1.3 geeft een beeld van de sectorale werkgelegenheidsdynamiek van beroepen. De tabel geeft de op middellange termijn voorspelde verschuiving weer

2. De groeiprognose is een aggregaat dat is afgeleid van de verwachte uitbreidingsvraag uit hoofdstuk 3.

6 
van de werkgelegenheidsaandelen van de drie beroepsniveaus binnen de onderscheiden dertien sectoren. Binnen elke sector kan iedere beroep zich verschillend ontwikkelen. Zo kan er bijvoorbeeld in een sector een verschuiving optreden van lagere naar hogere beroepen. Dit tezamen met de totale ontwikkeling van een sector vertaald zich naar een bepaalde ontwikkeling van een specifieke beroep binnen de sector. Voor het maken van de prognose van de uitbreidingsvraag in beroepen worden voor elke beroep de ontwikkelingen over alle sectoren samengevoegd. Zo zien wij dat binnen de sector Landbouw de toename van het aandeel van de elementaire en lagere beroepen ten koste gaat van de middelbare beroepen. Het aandeel van de hogere beroepen blijft hierbij gelijk. De tabel geeft slechts een verschuiving van het aandeel binnen de sector weer, niet of de elementaire beroepen in de landbouw daadwerkelijk groeien of krimpen. Dit is namelijk ook nog afhankelijk van de ontwikkeling van de absolute werkgelegenheidsomvang van de sector (zie ook hoofdstuk 3.).

Tabel 1.3

Verandering aandelen van beroepsniveaus binnen sectoren, 2003-2008

\begin{tabular}{|c|c|c|c|}
\hline & $\begin{array}{l}\text { Elementaire en } \\
\text { lagere } \\
\text { beroepen }\end{array}$ & $\begin{array}{l}\text { Middelbare } \\
\text { beroepen }\end{array}$ & $\begin{array}{l}\text { Hogere en } \\
\text { wetenschappelijke } \\
\text { beroepen }\end{array}$ \\
\hline Landbouw en visserij & + & - & $=$ \\
\hline Voeding & $=$ & - & $=$ \\
\hline Chemie & - & ++ & - \\
\hline Metaal en elektrotechniek & -- & + & ++ \\
\hline Overige industrie & ++ & -- & - \\
\hline Energie & $=$ & - & + \\
\hline Bouw en onroerend goed & ++ & -- & - \\
\hline Handel en reparatie & - & + & + \\
\hline Transport en communicatie & + & $=$ & - \\
\hline Bank- en verzekeringswezen & $=$ & + & - \\
\hline Horeca en zakelijke dienstverlening & - & - & + \\
\hline Kwartaire diensten & + & - & $=$ \\
\hline Overheid en onderwijs & + & - & $=$ \\
\hline \multicolumn{4}{|c|}{$\begin{array}{l}\text { Verschuiving van aandelen binnen sectoren: }++ \text { duidt op een grote positieve, }+ \text { een positieve, }= \\
\text { gelijkblijvend, - een negatieve, en - op een grote negatieve verschuiving binnen de sector. } \\
\text { Bron: ROA }\end{array}$} \\
\hline \multicolumn{4}{|c|}{$\begin{array}{l}\text { Opvallend is de diversiteit van de ontwikkeling over de sectoren. Een eenduidige } \\
\text { trend zoals deze in tabel } 1.2 \text { uit de prognoses was af te leiden, is hier moeilijker te } \\
\text { identificeren. Een verschuiving naar hogere beroepen is slechts waar te nemen voor } \\
\text { de Metaal en elektrotechniek, Energie, Handel en reparatie en Horeca en zakelijke } \\
\text { dienstverlening. Voor de Landbouw, Overige industrie, Bouw en ontroerend goed, } \\
\text { maar ook voor de Kwartaire diensten en Overheid en onderwijs is een verschuiving } \\
\text { richting elementaire beroepen vast te stellen. Het resultaat voor de hogere beroepen } \\
\text { in tabel } 1.2 \text { is kennelijk voornamelijk het gevolg van een gemiddeld sterkere groei } \\
\text { van de sectoren die relatief veel hogere beroepen hebben. }\end{array}$} \\
\hline
\end{tabular}


Tabel 1.4

Verandering van aandelen van opleidingscategorieën binnen sectoren, 2003-2008

\begin{tabular}{|c|c|c|c|c|c|}
\hline & $\begin{array}{l}\text { Basis- } \\
\text { onderwijs }\end{array}$ & VMBO & $\mathrm{MBO}$ & $\mathrm{HBO}$ & WO \\
\hline Landbouw en visserij & - & -- & ++ & $=$ & $=$ \\
\hline Voeding & -- & - & ++ & $=$ & $=$ \\
\hline Chemie & - & -- & ++ & - & $=$ \\
\hline Metaal en elektrotechniek & -- & - & ++ & + & + \\
\hline Overige industrie & - & $=$ & + & - & $=$ \\
\hline Energie & - & - & ++ & + & + \\
\hline Bouw en onroerend goed & - & - & ++ & - & $=$ \\
\hline Handel en reparatie & - & - & + & $=$ & $=$ \\
\hline Transport en communicatie & - & - & ++ & $=$ & $=$ \\
\hline Bank- en verzekeringswezen & - & $=$ & + & + & - \\
\hline Horeca en zakelijke dienstverlening & - & - & + & + & + \\
\hline Kwartaire diensten & $=$ & $=$ & + & + & - \\
\hline Overheid en onderwijs & - & $=$ & + & + & $=$ \\
\hline
\end{tabular}

Als we dit beeld vergelijken met de verandering van het opleidingsaandeel binnen de sectoren, kan een duidelijke trend richting MBO opleidingen gevonden worden. Deze hadden al het grootste werkgelegenheidsaandeel, maar blijken ook nog in alle sectoren aan belang toe te nemen. Dit lijkt op gespannen voet te staan met de verschuiving naar lagere beroepen in een aantal sectoren. Zoals al eerder vastgesteld, verdringen kennelijk veel MBO'ers de lager opgeleiden in de lagere beroepen.

\subsection{Vervangingsvraag: Demografische ontwikkeling en arbeidsmarkt- participatie}

De vervangingsvraag is de vraag naar nieuwe arbeidskrachten die ontstaat doordat de arbeidsplaatsen van werkenden die met pensioen gaan, arbeidsongeschikt worden of zich (tijdelijk) terugtrekken van de arbeidsmarkt, opnieuw moeten worden opgevuld. Een vervangingsvraag in beroepen kan bovendien ontstaan door de beroepsmobiliteit. Wij concentreren ons hier op de netto vervangingsvraag. Deze heeft alleen betrekking op de vervangingsbehoefte voorzover deze opgevuld zou moeten worden door schoolverlaters die op de arbeidsmarkt instromen.

Voor de vervangingsvraag zijn twee elementen van belang: de leeftijdsopbouw binnen sectoren, beroepen of opleidingen en de participatiegraad van de verschillende leeftijdsgroepen. Uit figuur 1.5 blijkt dat Overijssel een licht jongere leeftijdsopbouw heeft dan landelijk in de groep van 15-64 jarigen die voor de arbeidsmarkt van belang is. Voor de bepaling van de vervangingsvraag, die in hoofdstuk 3 en 4 wordt besproken, is inzicht in de leeftijdsopbouw per beroep of opleiding van belang.

8 
Figuur 1.5

Prognose leeftijdsopbouw Nederland en Overijssel 2004

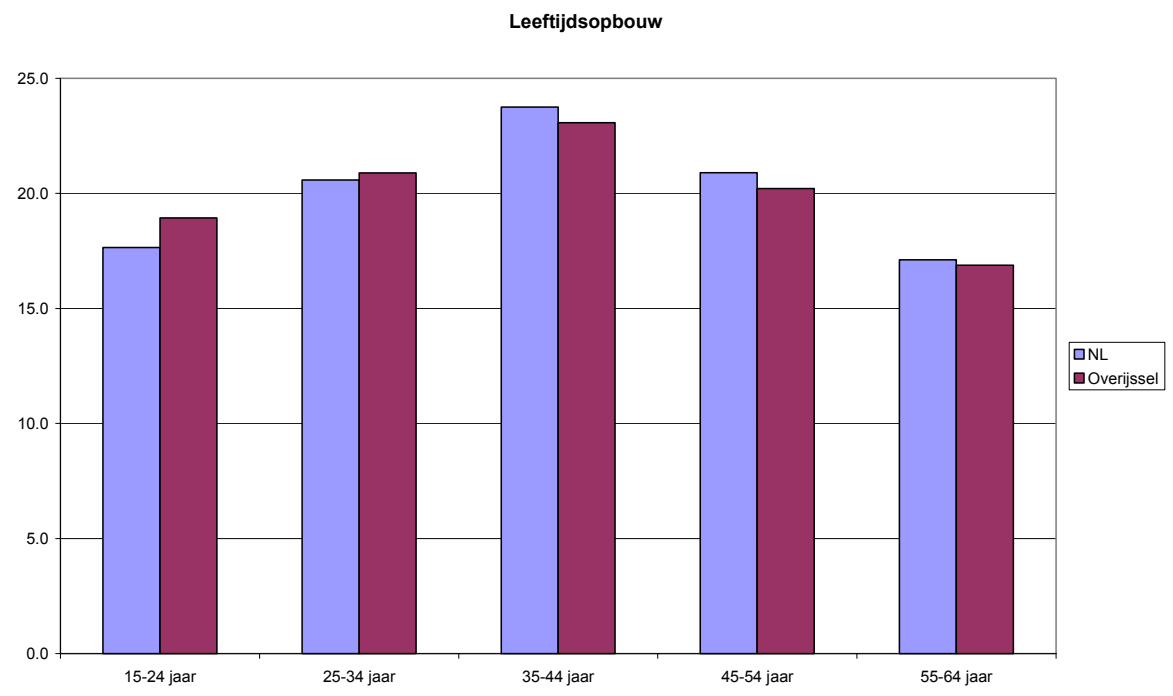

Bron: Etil

Figuur 1.6

Arbeidsmarktparticipatie Overijssel mannen en vrouwen

Arbeidsmarktparticipatie

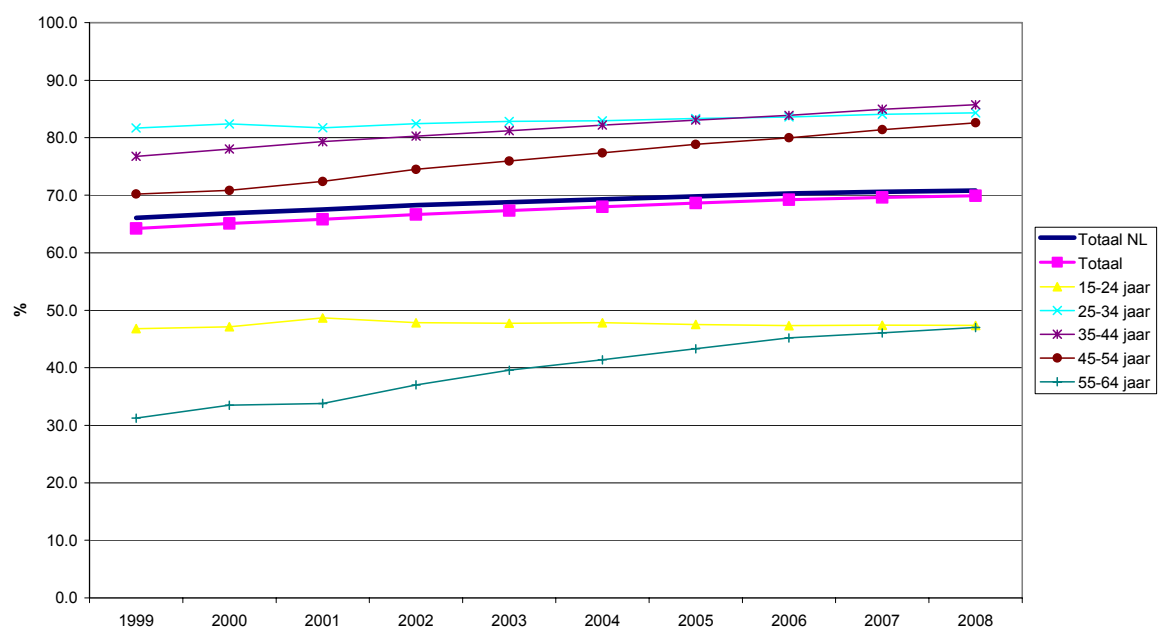

Bron: Etil 
De arbeidsmarktparticipatie is het tweede element dat een belangrijke invloed op de vervangingsvraag uitoefent. In figuur 1.6 is duidelijk te zien dat de participatie in de afgelopen jaren gestegen is. De landelijke prognoses voor de komende jaren - die ten grondslag ligt aan de prognoses voor Overijssel - laat een verdere stijging zien van de arbeidsmarktparticipatie, met name onder oudere werknemers. Dit is conform het beleid dat in de laatste jaren van de regering gevoerd werd om de arbeidsmarktparticipatie onder ouderen te verhogen. Ook speelt hier mee dat het gebruik van vervroegde pensioensregelingen in de toekomst wellicht moeilijker of duurder zal zijn en daardoor minder vaak zal voorkomen.

De tegenhanger van de vervangingsvraag is de arbeidsmarktinstroom van schoolverlaters en gediplomeerden. Deze wordt in hoofdstuk 2 nader beschreven. De confrontatie van instroom, vervangings- en uitbreidingsvraag, zal in hoofdstuk 4 aan de orde komen.

\subsection{Conclusie}

De sectorale werkgelegenheidsstructuur van de Overijsselse arbeidsmarkt is zodanig dat hiervan een gunstig effect uitgaat op de groei van de werkgelegenheid. De sectorale ontwikkeling wordt bij de prognoses vertaald naar beroepen en opleidingen. De voor de komende jaren voorspelde werkgelegenheidsontwikkeling laat bij opleidingen een duidelijke verschuiving zien van laag naar middelbaar tot hoger opgeleiden. Bij de beroepen zit gemiddeld gesproken de werkgelegenheidsgroei vrijwel uitsluitend bij de lagere en de hogere beroepen, het middelbare niveau stagneert. Aannemende dat voor de hogere beroepen ruim voldoende aanbod van hoger opgeleiden beschikbaar komt op de arbeidsmarkt en het aanbod van middelbaar opgeleiden blijft toenemen, valt te verwachten dat relatief veel middelbaar opgeleiden zullen moeten uitwijken naar lagere beroepen. De demografische opbouw van Overijssel is zodanig dat de bevolking enigszins jonger is dan die voor Nederland als geheel. Ondanks de lagere verwachte arbeidsmarktparticipatie zal de vervangingsvraag toch per saldo lager liggen dan in Nederland. 


\section{Deelname aan onderwijs en arbeidsmarktinstroom}

Het beroepsonderwijs is een belangrijke toeleveraar aan de arbeidsmarkt. In Overijssel volgt driekwart van de leerlingen een opleiding in het VMBO of MBO en behaalt daar een diploma. Van de werkzame Overijsselse beroepsbevolking heeft het overgrote deel beroepsonderwijs op lager of middelbaar niveau gevolgd. In dit hoofdstuk zullen wij daarom in het bijzonder het beroepsonderwijs belichten. Hierbij worden zowel de deelname als de instroom op de arbeidsmarkt nader toegelicht. Voor de afgelopen jaren vinden wij een lichte daling van het totaal aantal VMBO'ers, terwijl het aantal MBO'ers redelijk stabiel bleef. De sterkste groeier in de toekomstige instroom vanuit het beroepsonderwijs naar de arbeidsmarkt zal naar verwachting binnen het $\mathrm{VMBO}$ de richting Economie en binnen het $\mathrm{MBO}$ de richting Dienstverlening en gezondheidszorg zijn. De instroom vanuit MBO Natuur en techniek zal hierbij sterk achter blijven.

\subsection{Inleiding}

In dit hoofdstuk staat het Overijssels beroepsonderwijs centraal. De nadruk ligt hierbij op het in kaart brengen van het huidige en toekomstige aanbod van lager en middelbaar opgeleiden op de Overijsselse arbeidsmarkt. De focus van dit hoofdstuk is op de $\mathrm{VMBO}$ en $\mathrm{MBO}$ leerlingen en gediplomeerden omdat afgestudeerden van het hoger onderwijs doorgaans een grote mobiliteit laten zien en hierdoor minder afhankelijk zijn van de regionale arbeidsmarkt. Het grootste gedeelte van de schoolverlaters wordt daarmee besproken. Gemiddeld over de afgelopen 6 jaar beslaat het VMBO en MBO samen ongeveer $79 \%$ van alle gediplomeerden en $75 \%$ van de leerlingen.

De opzet van dit hoofdstuk is als volgt. In paragraaf 2.2 wordt aandacht geschonken aan het aantal leerlingen dat recent een VMBO-opleiding of een opleiding aan een Overijssels Regionaal Opleidingscentrum (ROC) of Agrarisch Opleidingscentrum (AOC) succesvol heeft afgerond. In paragraaf 2.3 wordt het aantal leerlingen dat momenteel in Overijssel een opleiding op VMBO- of MBO-niveau volgt besproken. Zo kan een indicatie worden gegeven van de toekomstige instroom van schoolverlaters op de arbeidsmarkt. Uiteraard zal niet elke gediplomeerde ook daadwerkelijk de arbeidsmarkt betreden. Uit cijfers voor Nederland ${ }^{3}$ weten wij dat van de VBO gediplomeerden ongeveer $51 \%$ verder studeert en $24 \%$ de opleiding beroepsbegeleidend $(\mathrm{BBL})$ vervolgt. De schoolverlaters van het algemeen voortgezette onderwijs (AVO) kozen zoals te verwachten en masse voor vervolgonderwijs: $88 \%$ ging verder met studeren en $4 \%$ koos voor een combinatie van werken en leren. $\mathrm{Bij}$ de beroepsopleidende leerweg (BOL) niveau $1 / 2$ en niveau $3 / 4$ gaat ongeveer de helft van de gediplomeerden verder met leren en gaat de andere helft werken. Bij de BBL-gediplomeerden niveau $1 / 2$ betreedt ongeveer $75 \%$ de arbeidsmarkt en bij de BBL-gediplomeerden van niveau $3 / 4$ ongeveer $88 \%$. In paragraaf 2.4 zal de

3. ROA (2003), Schoolverlaters tussen Onderwijs en Arbeidsmarkt. 
verwachte arbeidsmarktinstroom op de middellange termijn worden besproken, waarbij voor doorstuderen gecorrigeerd wordt. Voor Nederland als geheel geldt dat de arbeidsmarktinstroom (incl. HBO en WO) vanuit het initiële en postinitiële onderwijs jaarlijks ongeveer $4 \%$ van de werkende beroepsbevolking kan vervangen. ${ }^{4}$

\subsection{Het aantal gediplomeerden}

In tabel 2.1 wordt een overzicht gegeven van het aantal gediplomeerden in Overijssel naar onderwijssector. Uit de tabel blijkt dat in 20038.890 VMBO'ers hun opleiding succesvol hebben afgerond. Dit is $7 \%$ minder dan in 2002. Hiermee lijkt een kentering te zijn gekomen in de stijgende lijn die van 1998 tot 2002 zichtbaar was. Ongeveer een derde deel van de VMBO'ers heeft een opleiding volgens de theoretische leerweg gevolgd. Dit aandeel was in 2002 en eerdere jaren nog ongeveer $40 \%$.

Verder laat tabel 2.1 zien dat er in Overijssel in 2003 ongeveer 11.430 MBO'ers hun diploma hebben gehaald. Daarmee is het aantal gediplomeerden met ongeveer 100 gedaald ten opzichte van 2002. De meeste Overijsselse MBO'ers hebben een opleiding in de sector MBO Economie gevolgd. Het aandeel gediplomeerden met een techniek diploma is over de laatste vier jaren bezien aan het afnemen. Ongeveer een derde deel van de gediplomeerden heeft een BBL-opleiding gevolgd. Het aandeel BBL'ers is het grootst onder de MBO gediplomeerden met een techniek diploma (66\%) en het kleinst in de sector MBO Economie (22\%).

Tabel 2.1

Aantal gediplomeerden van het VMBO en het MBO in Overijssel naar opleidingscategorie en leerweg, 1998 en 2003.

\begin{tabular}{lccr}
\hline & 1998 & 2003 & $\begin{array}{r}\% \text { BBL } \\
(2003)\end{array}$ \\
& & & - \\
\hline VMBO Theorie & 3.980 & 2.760 & - \\
VMBO Natuur en techniek & 2.350 & 2.300 & - \\
VMBO Verzorging & 1.350 & 1.690 & - \\
VMBO Economie & 1.230 & 1.960 & - \\
VMBO Totaal (incl. Overig) & 9.080 & 8.890 & - \\
HAVO/VWO & 4.890 & 4.580 & 46 \\
& & & 22 \\
MBO Natuur en techniek & 3.740 & 3.620 & 39 \\
MBO Dienstverlening en & 2.850 & 3.620 & \\
gezondheidszorg & 3.370 & 3.700 & \\
MBO Economie & 9.980 & 11.430 & \\
MBO Totaal (incl. Overig) & & &
\end{tabular}

Bron: ROC's Overijssel (Bekostigingstellingen 2003, CFI/STOAS)

4. ROA (2003), de Arbeidsmarkt naar Opleiding en Beroep tot 2008. 
In figuur 2.1 wordt het aandeel gediplomeerden per opleidingsrichting van het VMBO voor de afgelopen zes jaren getoond. De figuur laat zien dat er in 2003 relatief meer gediplomeerden van VMBO Economie en VMBO Verzorging waren terwijl het aandeel gediplomeerden van VMBO Natuur en Techniek ongeveer constant bleef.

Figuur 2.1

VMBO-gediplomeerden naar opleidingscategorie, 1998-2003, \%.

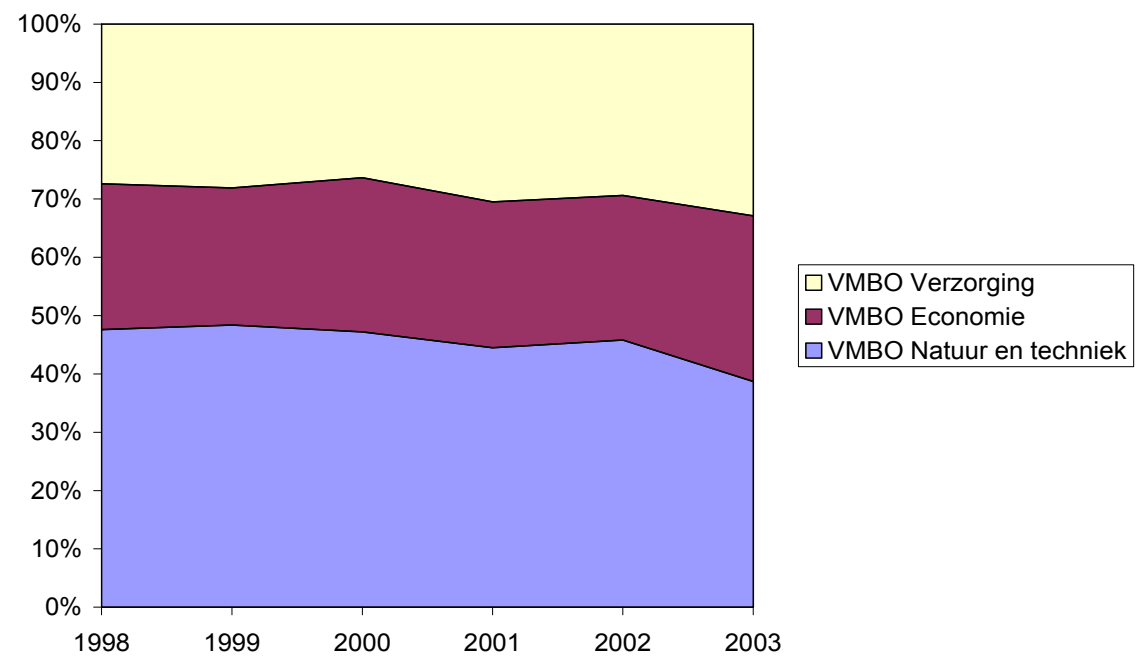

Bron: ROC's Overijssel (Bekostigingstellingen 2003, CFI/STOAS)

Figuur 2.2

MBO-gediplomeerden naar opleidingscategorie, 1998-2003, \%.

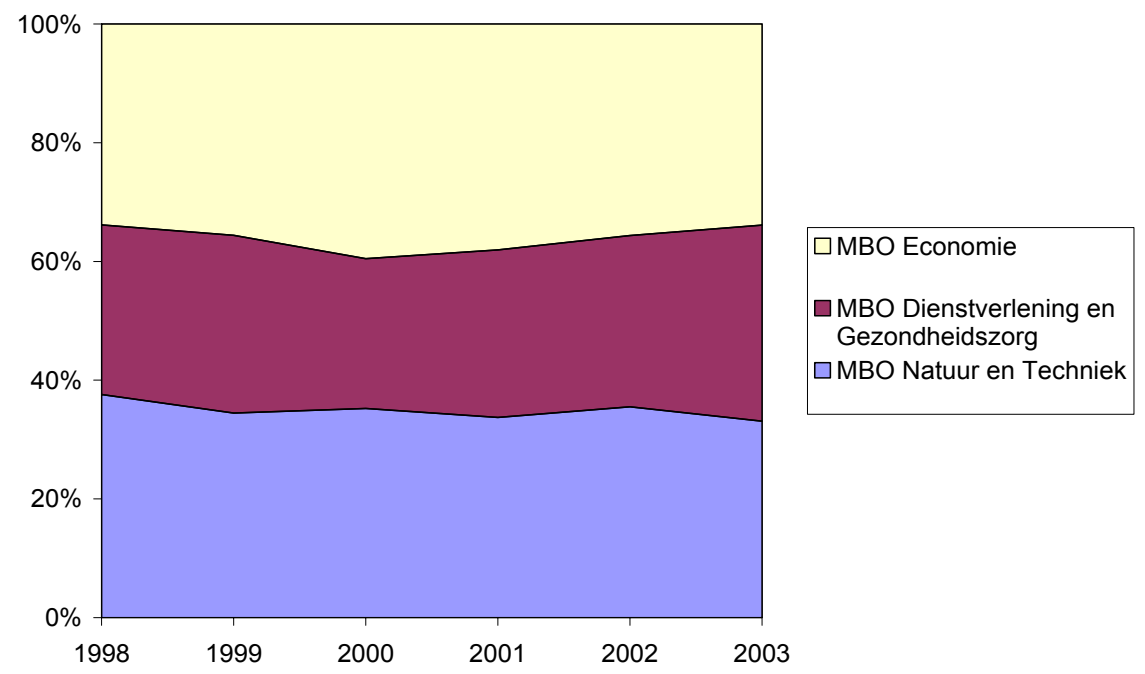

Bron: ROC's Overijssel (Bekostigingstellingen 2003, CFI/STOAS) 
Figuur 2.2 laat de gediplomeerden zien met een MBO opleiding. Het aandeel MBOafgestudeerden met een Economie diploma blijkt de laatste jaren kleiner te worden.

\subsection{Het aantal leerlingen}

Met behulp van het aantal leerlingen kan een eerste indicatie worden gegeven van het toekomstige arbeidsaanbod. Het overgrote deel van de VMBO-leerlingen in Overijssel (35.770 leerlingen van in totaal 49.990 VMBO-leerlingen) volgt de theoretische leerweg of zit in de eerste twee jaar van deze opleiding (de zogenaamde basisvorming). Dit aandeel is met ongeveer $5 \%$ gedaald ten opzichte van 1997. Met name VMBO Economie en VMBO Verzorging zijn populairder geworden. Populaire richtingen binnen het $\mathrm{VMBO}$ zijn bouwtechniek en voertuigentechniek. Het aantal leerlingen in het $\mathrm{MBO}$ blijft, in vergelijking met eerdere jaren redelijk constant op 41.500. De sector MBO Economie is het grootst. Er gaan steeds minder MBOleerlingen een techniek opleiding volgen. ${ }^{5}$

Tabel 2.2

Aantal (bekostigde) leerlingen in het VMBO en het MBO in Overijssel naar opleidingscategorie en leerweg, kalenderjaar 1997 en 2003

\begin{tabular}{|c|c|c|c|}
\hline & 1997 & 2003 & $\begin{array}{l}\% \text { BBL } \\
(2003)\end{array}$ \\
\hline VMBO Theorie & 35.140 & 35.770 & - \\
\hline VMBO Natuur en techniek & 5.460 & 5.500 & - \\
\hline VMBO Verzorging & 2.900 & 4.440 & - \\
\hline VMBO Economie & 2.850 & 4.200 & - \\
\hline VMBO Totaal (incl. Overig) & 46.610 & 49.990 & - \\
\hline HAVO/VWO & 21.930 & 21.690 & - \\
\hline MBO Natuur en techniek & 16.160 & 12.350 & 52 \\
\hline MBO Dienstverlening en gezondheidszorg & 11.010 & 12.830 & 31 \\
\hline MBO Economie & 12.620 & 14.900 & 23 \\
\hline MBO Totaal (incl. Overig) & 39.810 & 40.620 & 34 \\
\hline
\end{tabular}

Bron: AOC en ROC's Overijssel (Bekostigingstellingen 2003, CFI/STOAS)

Eenderde deel van de Overijsselse MBO'ers volgt een opleiding volgens de meer praktisch georiënteerde beroepsbegeleidende leerweg. Dit percentage is lager dan het percentage BBL-gediplomeerden, zoals dat in tabel 2.1 werd gepresenteerd. Dit kan erop wijzen dat de populariteit van de BBL bij de studiekiezer of bij de werkgever die een leerlingplaats moet creëren aan het afnemen is. Dit is ook op temaken uit de cijfers van 2002 ten opzichte van 2003 (tabel 2.1 in de statistische bijlage) die voor

5. Voor een overzicht van de onderliggende richtingen binnen de opleidingen zie tabel 2.1 in de statistische bijlage. 
de meeste opleidingstypes een daling van het percentage BBL laten zien. Het kan er daarnaast ook op wijzen dat de uitval in de BBL lager is dan in de BOL.

\section{Figuur 2.3}

VMBO-leerlingen naar opleidingscategorie, 1997-2003, \%.

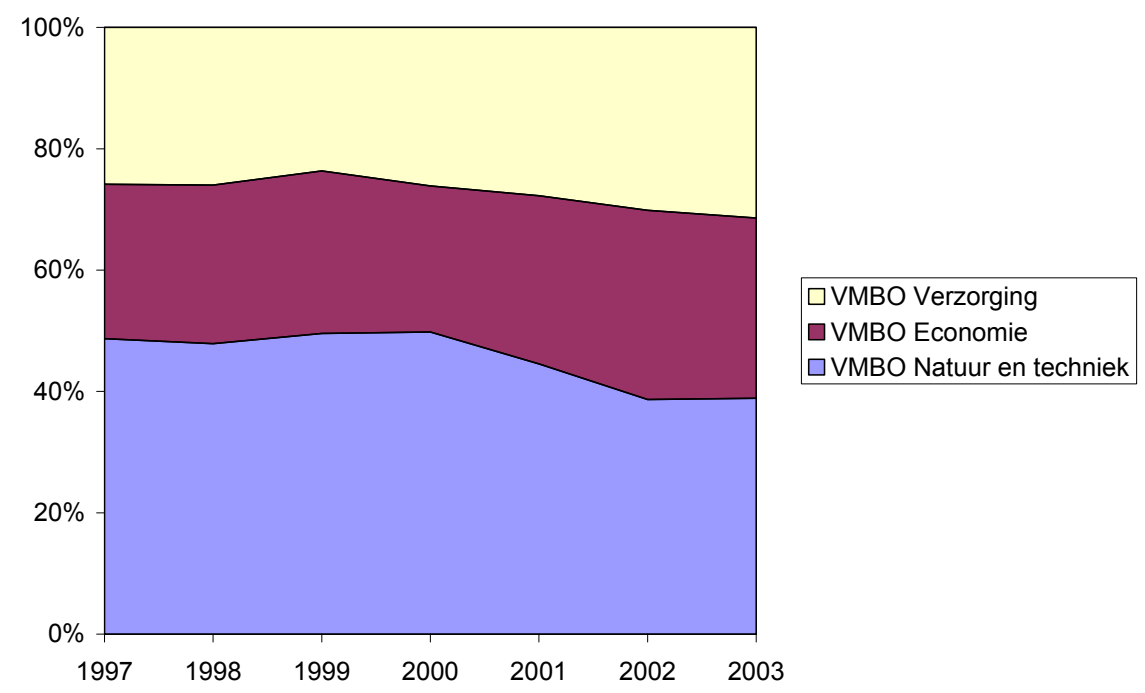

Bron: AOC en ROC's Overijssel (Bekostigingstellingen 2003, CFI/STOAS)

Figuur 2.4

MBO-leerlingen naar opleidingscategorie, 1997-2003, \%

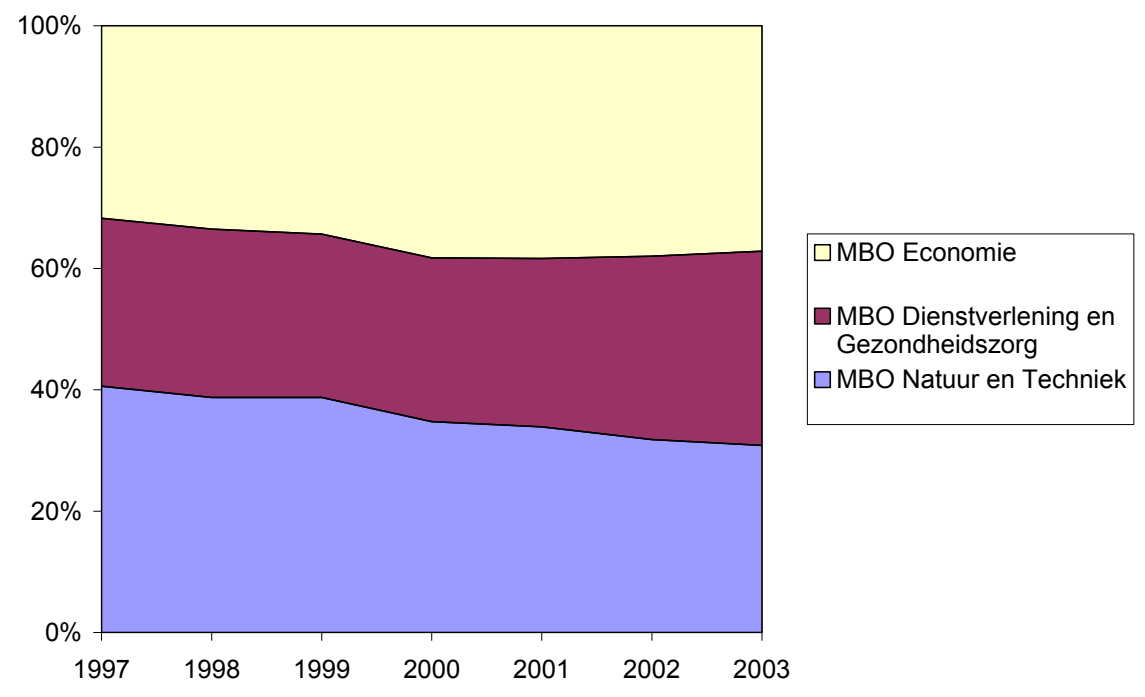

Bron: AOC en ROC's Overijssel (Bekostigingstellingen 2003, CFI/STOAS) 
Opvallend is dat in de sector MBO Dienstverlening en gezondheidszorg ongeveer $69 \%$ van de leerlingen een BOL-opleiding volgt, terwijl van de gediplomeerden ongeveer $56 \%$ een BOL-diploma heeft. Het aandeel leerlingen dat een opleiding in de sector MBO Dienstverlening en gezondheidszorg volgens de BOL volgt is dus groter dan het aandeel dat zij hebben in het aantal gediplomeerden van deze sector. Zoals al gezegd, kan dit erop wijzen dat in deze sector de uitval uit de BOLopleidingen relatief groot is. Hetzelfde geldt voor de techniek opleidingen waar ongeveer $48 \%$ van de leerlingen een BOL-opleiding volgt ten opzichte van $34 \%$ van de gediplomeerden. Wellicht is het raadzaam leerlingen meer op de mogelijkheden in de BBL te wijzen, die door het meer praktische en daarmee laagdrempelige karakter een belangrijke rol kan vervullen in het streven iedereen een startkwalificatie te laten behalen. In de overige sectoren is het aantal leerlingen in de verschillende leerwegen meer in balans met het aantal gediplomeerden.

Daarnaast valt op dat er binnen het VMBO relatief veel minder gediplomeerden dan leerlingen van VMBO Theorie zijn. De overige richtingen binnen het VMBO hebben relatief meer gediplomeerden dan leerlingen. Een belangrijke reden hiervoor is van statistische aard. Het leerlingenaantal van VMBO Theorie omvat namelijk ook de leerlingen van de eerste twee jaar basisvorming die nog naar beroepsvoorbereidende richtingen zullen doorstromen.

Figuur 2.3 laat zien dat het aandeel VMBO-leerlingen met een Natuur en techniek diploma sinds 2000 met ongeveer $12 \%$ is afgenomen. Het aandeel leerlingen binnen VMBO Verzorging en VMBO Economie is toegenomen. Figuur 2.4 toont dat MBO Natuur en techniek ook steeds minder populair wordt. Steeds meer leerlingen kiezen voor een opleiding binnen MBO Dienstverlening en gezondheidszorg.

Figuur 2.5

Leerlingen per opleidingsrichting naar geslacht, 2003

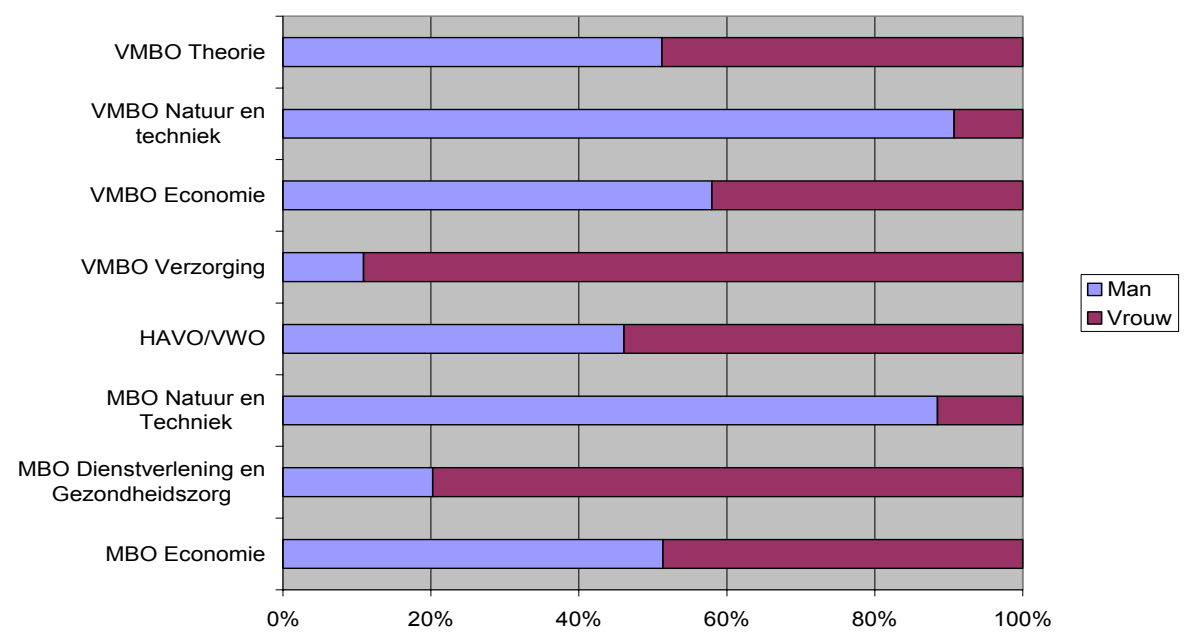

Bron: AOC en ROC's Overijssel (Bekostigingstellingen 2003, CFI/STOAS) 
Traditioneel zijn er grote verschillen in de opleidingskeuze van mannen en vrouwen. Uit figuur 2.5 blijkt dat de grootste verschillen zich voordoen bij de techniek opleidingen op VMBO en MBO niveau, VMBO Verzorging en MBO Dienstverlening en gezondheidszorg. Slechts $6 \%$ van de leerlingen die een opleiding op VMBO niveau in een technische richting volgt is vrouw. Op MBO niveau is dit ongeveer $8 \%$. In de zorg sector is daarentegen ongeveer $89 \%$ van de $\mathrm{VMBO}$ - en $80 \%$ van de $\mathrm{MBO}$ leerlingen vrouw.

\subsection{Aanbod van schoolverlaters}

In deze paragraaf wordt een overzicht gegeven van de verwachte arbeidsmarktinstroom in Overijssel op de middellange termijn. Hierbij worden alleen de lagere en middelbare opleidingssectoren besproken omdat, zoals al opgemerkt, afgestudeerden van het hoger onderwijs doorgaans een grote mobiliteit laten zien en hierdoor veel minder afhankelijk zijn van de perspectieven op de regionale arbeidsmarkt.

\section{Opleidingssectoren}

De verwachte arbeidsmarktinstroom van schoolverlaters ligt over de middellange termijn gezien voor de meeste lagere en middelbare opleidingssectoren rond de $20 \%$ à $30 \%$ van de in het basisjaar werkenden uit de desbetreffende opleidingssector. $\mathrm{Er}$ zijn hierbij twee belangrijke uitschieters, één omhoog, VMBO Economie (47\%), en één omlaag, MBO Natuur en techniek (18\%). De arbeidsmarktinstroom vanuit de verschillende VMBO-opleidingen en het HAVO/VWO is voor een belangrijk deel afkomstig van werkenden die postinitieel een dergelijke opleiding hebben gevolgd. Door het afronden van één van deze opleidingen ontstaat er aan de vraagzijde vervangingsvraag naar arbeidskrachten met de 'oude' opleidingsachtergrond (bijv. ongeschoolden).

Tabel 2.3

Verwachte arbeidsmarktinstroom van schoolverlaters naar opleidingssector in Overijssel, 20032008 , in procenten van de werkenden uit de sector in 2003

\begin{tabular}{lrr} 
& Overijssel 2003-2008 & Nederland 2003-2008 \\
$\%$ & $\%$ \\
\hline Basisonderwijs & 31 & 24 \\
VMBO Theorie & 22 & 23 \\
VMBO Natuur en techniek & 26 & 26 \\
VMBO Economie & 52 & 47 \\
VMBO Verzorging & 29 & 32 \\
HAVO/VWO & 29 & 37 \\
MBO Natuur en techniek & 17 & 18 \\
MBO Economie & 21 & 22 \\
MBO Dienstverlening en gezondheidszorg & 25 & 29 \\
Totaal (incl. HBO en WO) & 23 & 22 \\
\hline Bron: ROA & &
\end{tabular}




\section{Lagere en middelbare opleidingstypen met een relatief hoge}

arbeidsmarktinstroom van schoolverlaters in Overijssel:

- $\quad \mathrm{MBO}$ sociaal-pedagogisch en welzijn

- VMBO consumptief en levensmiddelentechniek

- MBO ICT

- VMBO administratie, handel en mode

- $\mathrm{MBO}$ facilitaire dienstverlening

- $\mathrm{MBO}$ horeca

Lagere en middelbare opleidingstypen met een relatief lage arbeidsmarktinstroom van schoolverlaters in Overijssel:

- MBO werktuigbouw en mechanische techniek

- MBO levensmiddelentechniek/vleesverwerking

- VMBO transport en logistiek

- MBO openbare orde en veiligheid

- $\mathrm{MBO}$ administratie en logistiek

- MBO elektrotechniek

De arbeidsmarktinstroom over de middellange termijn levert voor Overijssel en Nederland een vergelijkbaar beeld op. Op MBO-niveau ligt de arbeidsmarktinstroom in Overijssel over het algemeen even hoog als voor Nederland. Voor de lagere opleidingssectoren is de Overijsselse arbeidsmarktinstroom relatief lager dan de landelijke arbeidsmarktinstroom voor VMBO Theorie, VMBO Verzorging en HAVO/VWO. Daarentegen is voor Basisonderwijs en VMBO Economie de arbeidsmarktinstroom van schoolverlaters iets groter dan landelijk.

De arbeidsmarktinstroom per opleidingssector bestaat uit verschillende opleidingstypen. Dit houdt in dat de relatief lage gemiddelde instroom van de opleidingssector MBO Natuur en techniek niet bij alle onderliggende opleidingstypen te vinden is. Zo blijkt dat MBO Installatietechniek met 32\% relatief veel instroom heeft terwijl het opleidingstype MBO Werktuigbouw en mechanische techniek met $9 \%$ de laagste instroom heeft van alle opleidingstypen.

\subsection{Conclusie}

In 2003 hebben bijna 9.000 VMBO'ers hun opleiding succesvol afgerond. Dit is 7\% minder dan in 2002. Hiermee lijkt een kentering te zijn gekomen in de stijgende lijn die van 1998 tot 2002 zichtbaar was. Ongeveer een derde deel van de VMBO'ers heeft een opleiding volgens de theoretische leerweg gevolgd. Dit aandeel was in 2002 en eerdere jaren nog ongeveer 40\%. Er hebben ongeveer 11.500 MBO'ers hun diploma gehaald. Daarmee is het aantal gediplomeerden bijna gelijk gebleven ten opzichte van 2002. De meeste Overijsselse MBO'ers hebben een opleiding in de 
sector MBO Economie gevolgd. Het aandeel gediplomeerden met een techniek diploma is neemt over de laatste vier jaren bezien af. Ongeveer een derde deel van de gediplomeerden heeft een BBL-opleiding gevolgd. Het aandeel BBL'ers is het grootst onder de MBO gediplomeerden met een techniek diploma (66\%) en het kleinst in de sector MBO Economie (22\%).

Het overgrote deel van de 50.000 VMBO-leerlingen volgt de theoretische leerweg of zit in de eerste twee jaar van deze opleiding (de zogenaamde basisvorming). Dit aandeel is met ongeveer $5 \%$ gedaald ten opzichte van 1997. Met name VMBO Economie en VMBO Verzorging zijn populairder geworden. Het aantal leerlingen in het $\mathrm{MBO}$ blijft, in vergelijking met eerdere jaren, redelijk constant op 41.500 leerlingen. De sector MBO Economie is het grootst. Er gaan steeds minder MBOleerlingen een techniek opleiding volgen. Een derde deel van de Overijsselse MBO'ers volgt een opleiding volgens de meer praktisch georiënteerde beroepsbegeleidende leerweg.

De verwachte arbeidsmarktinstroom van schoolverlaters als percentage van de werkenden uit de desbetreffende opleidingssector ligt voor de meeste lagere en middelbare opleidingssectoren op de middellange termijn rondde $20 \%$ à $30 \%$, met twee belangrijke uitschieters: VMBO Economie (47\%) en MBO Natuur en techniek (18\%). De arbeidsmarktinstroom vanuit de verschillende VMBO-opleidingen en het HAVO/VWO is voor een belangrijk deel afkomstig van werkenden die postinitieel een dergelijke opleiding hebben gevolgd. 



\section{De Overijsselse arbeidsmarkt op middellange termijn}

De arbeidsmarktprognose 2003-2008 voor Overijssel is voor wat de uitbreidingsvraag betreft gebaseerd op een gematigde groeiverwachting voor de werkgelegenheid in bedrijfssectoren. De verwachte sectorale werkgelegenheidsontwikkeling wordt vertaald in een toekomstige uitbreidingsvraag voor beroepen en opleidingen. Het tweede element aan de vraagzijde van de arbeidsmarkt is de vervangingsvraag - het aantal werkenden dat vervangen moet worden omdat zij door hun leeftijd de arbeidsmarkt verlaten of om andere redenen niet meer in dezelfde baan blijven of van opleiding zijn veranderd. Tezamen vormen de uitbreidingsvraag, voorzover deze positief is, en de vervangingsvraag de baanopeningen die doorschoolverlaters en andere werkzoekenden vervuld moeten worden.

De voorspelde sectorale groei voor Overijssel is enigszins hoger dan de vijfjaarsprognose voor Nederland. De industriële sectoren zowel als de landbouw vertonen een krimpende werkgelegenheid. Dit komt overeen met de Nederlandse cijfers. De groei van de werkgelegenheid komt vanuit de sectoren Handel en reparatie, Horeca en zakelijke dienstverlening en de (semi-)overheidssectoren. Opvallend is de krimp van de werkgelegenheid in het Bank- en verzekeringswezen en de groei in Transport en communicatie, wat tegen de Nederlandse trend ingaat.

Deze sectorale werkgelegenheidsontwikkeling vertaalt zich in een positieve groei van de werkgelegenheid voor informatica- en culturele beroepen. Ook de pedagogische en medische beroepen profiteren van de vergroting van de werkgelegenheid, vooral in de Kwartaire diensten en bij de overheid en het onderwijs. Bij de werkgelegenheid voor opleidingen is het doorzetten van de trend naar hogere opleidingen te zien. Negatieve uitbreidingsvraag, d.w.z. een voorspelde krimp van de werkgelegenheid, is vooral onder ongeschoolden en laaggeschoolden te vinden.

Een belangrijke en tegelijk stabiliserende factor op de arbeidsmarkt is de vervangingsvraag. Door het invullen van vrijgekomen banen ontstaat het gros van de baanopeningen bij veel beroepsgroepen. De vervangingsvraag wordt beïnvloed door de participatiegraden en de demografische ontwikkeling binnen sectoren en beroepen. De vervangingsvraag in Overijssel ligt iets onder het Nederlandse niveau.

De baanopeningen zijn dankzij de positievere uitbreidingsvraag hoger in Overijssel dan voor Nederland voorspeld werd. Vooral de informatica- en culturele beroepen profiteren van de hoge uitbreidingsvraag, door het hoge aandeel van deze vraag in het totaal aan baanopeningen voor deze beroepen. Bij de opleidingen is een tweedeling zichtbaar: lagere opleidingen zijn vooral van de vervangingsvraag afhankelijk terwijl hogere opleidingen een groot deel van de baanopeningen door de uitbreidingsvraag gecreëerd zien. 


\subsection{Inleiding}

In dit hoofdstuk wordt nader ingegaan op de verwachte vraag- en aanbodontwikkelingen op de Overijsselse arbeidsmarkt op de middellange termijn (2003-2008). Dit hoofdstuk correspondeert direct met hoofdstuk 3 van het vorige rapport, 'Ratio De Overijsselse arbeidsmarkt naar opleiding en beroep 2001-2006'. Dit keer is er echter geen korte termijn prognose gemaakt. De opzet van het hoofdstuk is als volgt. In paragraaf 3.2 zal de actuele situatie van de vacaturemarkt naar beroep worden geschetst. Paragraaf 3.3 belicht de verwachte uitbreidingsvraag naar bedrijfssector, beroep en opleiding. In paragraaf 3.4 wordt de vervangingsvraag naar beroep en opleiding besproken. Bij zowel de uitbreidings- als de vervangingsvraag zullen de hoofdlijnen per beroepsklasse en opleidingssector worden weergegeven. Ook de onderliggende opleidingstypen met de grootste dan wel de kleinste verwachte groei (of krimp in het geval van negatieve groei) zullen apart worden besproken. De uitbreidings- en vervangingsvraag vormen tezamen de totale verwachte vraag (baanopeningen) naar nieuwe arbeidskrachten. De prognose van het aantal baanopeningen naar beroep wordt behandelt in paragraaf 3.5.

\subsection{Vacatures}

Vacatures geven een beeld van de huidige situatie aan de vraagzijde van de arbeidsmarkt. Zij geven een inschatting van de actuele tekorten aan werknemers in beroepen en in sectoren. Wij zullen deze inschatting maken op basis van de vacaturegegevens zoals deze door het CWI gepubliceerd worden. Deze kunnen echter nooit een volledig beeld geven van de openstaande vacatures, omdat slechts een deel van de beroepen via het CWI bemiddeld wordt, en ook omdat slechts een deel van de bedrijven gebruik maakt van het CWI om vacatures te melden. Wel kunnen ze een algemeen beeld geven van de mogelijke krapte op de arbeidsmarkt. In Tabel 3.1 geven wij de vacaturegraad per sector weer. De vacaturegraad is gedefinieerd als het aantal vacatures per 1.000 werknemers in de desbetreffende bedrijfssector.

Er is een hoge vacaturegraad in de voedingsindustrie en bij de Horeca en zakelijke dienstverlening. Opvallend is dat de hoge vacaturegraad in de voedingsindustrie gepaard gaat met een voorspelde werkgelegenheidskrimp in deze sector (vgl. tabel 3.2). Laag zijn de vacaturegraden bij Energie, Chemie, landbouw en de Overige industrie. Dit correspondeert ook enigszins met de negatieve uitbreidingsvraag in deze sectoren. Ook Bank- en verzekeringswezen, waarvoor een toekomstige krimp voorspeld wordt, blijkt nog een hoge vacaturegraad te kennen. Onder de beroepen hebben vooral de hogere beroepen zoals bijvoorbeeld managers en hogere pedagogische beroepen een erg lage vacaturegraad. Dit is het gevolg van de gebruikte databron. De vacatures worden verzameld door het CWI onder de bij hun ingeschreven banen. Slechts weinig managementfuncties of andere hogere beroepen worden via het CWI bezet. Vooral onder de hogere beroepen zal dus de vacaturegraad vertekend zijn. Onder de middelbare agrarische beroepen vinden wij bijvoorbeeld een erg lage vacaturegraad. Dit correspondeert wederom met de daling van de 
werkgelegenheid in de gehele landbouwsector. Verder is onder de transportberoepen - laag en middelbaar - een lage vacaturegraad te vinden. Aan het andere einde van het spectrum bevinden zich de verzorgende beroepen: laag en middelbaar kennen een hoge tot zelfs zeer hoge vacaturegraad. Technische beroepen vertonen op alle niveaus een hoge vacaturegraad, dit kan onder meer het gevolg zijn van mismatch. De vacatures hebben speciale competentie-eisen die niet makkelijk onder (lokale) werkzoekenden in te vullen is.

Tabel 3.1

Vacaturegraad per sector in Overijssel, 2004, promillages

\begin{tabular}{lr}
\hline Bedrijfssector & Vacaturegraad \\
\hline Landbouw en visserij & 5 \\
Voeding & 41 \\
Chemie & 4 \\
Metaal en elektrotechniek & 8 \\
Overige industrie & 6 \\
Energie & 2 \\
Bouw en onroerend goed & 15 \\
Handel en reparatie & 11 \\
Transport en communicatie & 11 \\
Bank- en verzekeringswezen & 28 \\
Horeca en zakelijke dienstverlening & 46 \\
Kwartaire diensten & 12 \\
Overheid en onderwijs & 10 \\
Totaal & 17 \\
\hline
\end{tabular}

Bron: CWI / Etil - April 2004

\subsection{Uitbreidingsvraag}

\section{Bedrijfssectoren}

De vraag naar schoolverlaters wordt door twee componenten bepaald: de uitbreidingsvraag ten gevolge van de verwachte werkgelegenheidsgroei en de vervangingsvraag veroorzaakt door (tijdelijke) uitstroom van reeds werkenden. In deze paragraaf bespreken we de uitkomsten voor de eerste vraagcomponent: de uitbreidingsvraag. Tabel 3.2 geeft voor de verschillende sectoren de uitbreidingsvraag op de middellange termijn (2003-2008) weer als percentage van de werkgelegenheid in het basisjaar (2003). ${ }^{6}$ Voor de middellange termijn worden deze cijfers tevens vergeleken met het landelijke beeld. ${ }^{7}$

6. Voor de middellange termijn is - conform de landelijke prognose - de periode 2003-2008 gekozen. Basisdata voor de prognose zijn de meest recente "Enquête Beroepsbevolking", EBB 2002.

7. ROA (2003), De arbeidsmarkt naar opleiding en beroep tot 2008, ROA-R-2003/11. 
Tabel 3.2

Verwachte uitbreidingsvraag naar bedrijfssector 2003-2008, Overijssel en Nederland, percen tage van werkenden 2003

Bedrijfssector

Overijssel 2003-2008 Nederland 2003-2008

\begin{tabular}{lrc} 
Landbouw en visserij & -11 & -12 \\
Voeding & -4 & -1 \\
Chemie & -3 & -6 \\
Metaal en elektrotechniek & -9 & -9 \\
Overige industrie & -3 & -6 \\
Energie & 0 & 2 \\
Bouw en onroerend goed & 0 & -3 \\
Handel en reparatie & 12 & 2 \\
Transport en communicatie & 2 & -5 \\
Bank- en verzekeringswezen & -10 & 6 \\
Horeca en zakelijke dienstverlening & 7 & 3 \\
Kwartaire diensten & 14 & 6 \\
Overheid en onderwijs & 7 & 5 \\
Totaal & & 1 \\
\hline Bron:
\end{tabular}

Bron: CPB/ETIL/ROA

De voorspelde totale groei van Overijssel is enigszins hoger dan de $1 \%$ die voor Nederland als geheel is voorspeld. In de tijd die sinds het opstellen van het landelijke rapport is verstreken zijn de prognoses op basis van de recente conjuncturele ontwikkeling positief bijgesteld. Drijvende krachten zijn met name de sectoren Handel en reparatie, Horeca en dienstverlening, maar ook de Kwartaire diensten en Overheid en onderwijs. Met name de laatste twee laten een bepaalde fragiliteit van de prognose zien. De uitwerking van de huidige bezuinigingsmaatregelen zijn voor de kwartaire en overheidssector echter nog niet te overzien, ten minstens wat betreft de werkgelegenheid. Juist deze twee sectoren zijn in Overijssel relatief groot (vgl. figuur 1.1 in Hoofdstuk 1 van dit rapport). De landelijke trend van afnemende werkgelegenheid in de industrie is ook in Overijssel terug te vinden. Opvallend is hier vooral de sterkere daling van de voedingsindustrie. Tegen de landelijke trend in gaat de al eerder genoemde sterke groei van de Handel en reparatie, maar ook de dalende werkgelegenheidsontwikkeling in het Bank- en verzekeringswezen. Het Bank- en verzekeringswezen is in Overijssel een tamelijk kleine sector. De krimp is daarom niet zo belangrijk voor het totaalcijfer. De voor Overijssel grote sectoren Kwartaire diensten, Overheid en onderwijs, Handel en reparatie, en Horeca en dienstverlening vertonen een beter of duidelijk beter beeld dan de prognose die aan het landelijke model ten grondslag ligt. Dit is te danken aan de positievere vooruitzichten sinds het opstellen van de landelijke rapportage. 


\section{Beroepsklassen}

De verwachte groei of krimp van de werkgelegenheid naar bedrijfssector heeft gevolgen voor de werkgelegenheid naar beroep. In tabel 3.3 wordt de uitbreidingsvraag naar beroepsklasse weergegeven. De twaalf beroepsklassen omvatten 128 beroepsgroepen. ${ }^{8}$ De onderliggend beroepsgroepen en hun uitbreidingsvraag zijn in tabel 4.2 van de statistische bijlage aan het einde van dit rapport terug te vinden. De verwachte uitbreidingsvraag verschilt nogal van het landelijke beeld zoals dit in de landelijke rapportage geschetst werd.

Hoewel de uitbreidingsvraag naar Agrarische, en ook Technische, ambachts- en industrieberoepen zowel landelijk als ook in Overijssel terugloopt, is deze terugloop minder sterk in de provincie. Dit komt door de over het algemeen positievere vooruitzichten voor Overijssel. Bij de Agrarische beroepen zijn vooral de middelbare beroepen die een lagere uitbreidingsvraag vertonen. Dit gaat voornamelijk ten koste van op VMBO niveau of lager geschoolde werknemers. Bij de technische beroepen is het beeld divers: terwijl bijvoorbeeld conciërges een hoge uitbreidingsvraag vertonen, zijn typische industrieberoepen zoals productiemedewerkers, bankwerkers en lassers, werktuigbouwkundige ontwerpers en elektromonteurs duidelijk de dupe van een tegenvallend uitbreidingsvraag. Ook de uitbreidingsvraag naar de Economisch-administratieve, de Transportberoepen en de Openbare orde beroepen is in Overijssel iets gunstiger dan bij de prognose voor Nederland. Veel gunstiger zijn vooral de Pedagogische beroepen, de Culturele beroepen, de (Para-)medische beroepen, de Informatica-, en de Verzorgende en dienstverlenende beroepen. De Pedagogische beroepen profiteren van een grote uitbreidingsvraag naar leraren in het basisonderwijs maar ook naar $1^{\mathrm{e}}, 2^{\mathrm{e}}$, en $3^{\mathrm{e}}$ graads lesbevoegde leraren van bijna alle vakrichtingen. Slechts de docenten voor landbouw en van sociale vakken hebben een lage uitbreidingsvraag. De kleine groep van Culturele beroepen profiteert van de uitbreidingsvraag naar bibliotheekmedewerkers en ook naar journalisten. Bij de Informaticaberoepen doet zich naar verwachting een duidelijke substitutie voor van programmeurs en systeemanalisten ten koste van informatici en technische systeemanalisten. De (Para)medische beroepen hebben vooral een hoge uitbreidingsvraag onder de grote groep van therapeuten en verpleegkundigen maar ook onder de meer bestuurlijke functies van Afdelingshoofden zorginstellingen. Overal correspondeert de beroepensamenstelling met de sectorale ontwikkeling. Beroepsklassen die in groeiende bedrijfssectoren zitten, hebben een grotere uitbreidingsvraag.

Aangezien de vooruitzichten voor een beroepsklasse niet noodzakelijkerwijs hoeven te gelden voor alle onderliggende beroepsgroepen, zijn in het kader de meest opvallende uitkomsten op beroepsgroepenniveau weergegeven. ${ }^{9}$ Het betreft de vier

8. Voor een indeling van beroepsgroepen in beroepsklassen zie bijvoorbeeld tabel 4.13 in de statistische bijlage.

9. Voor het complete overzicht van de middellangetermijnprognoses op dit lagere aggregatieniveau wordt verwezen naar het 'Arbeidsmarkt Informatiesysteem' (AIS) voor Overijssel. Dit en de volgende kaders geven de hoogste en laagste procentuele verandering van een bepaalde beroepsgroep ofwel opleidingsrichting weer. Vaak zijn dit kleinere groepen die sterkere schommelingen vertonen. 
Tabel 3.2

Verwachte uitbreidingsvraag naar beroepsklasse 2003-2008, Overijssel en Nederland, percentage van werkenden in 2003

\begin{tabular}{lcc}
\hline & & Overijssel \\
Beroepsklasse & $2003-2008$ & 2008 \\
& & 5 \\
Pedagogische beroepen & 10 & 5 \\
Culturele beroepen & 19 & -9 \\
Agrarische beroepen & -7 & -3 \\
Technische, ambachts- en industrieberoepen & -1 & 0 \\
Transportberoepen & 3 & 3 \\
Medische en paramedische beroepen & 11 & 1 \\
Economisch-administratieve beroepen & 3 & 11 \\
Informatica beroepen & 22 & 4 \\
Sociaal-culturele beroepen & 2 & 3 \\
Verzorgende en dienstverlenende beroepen & 9 & 2 \\
Openbare orde- en veiligheidsberoepen & 5 & 1 \\
Totaal & & 4 \\
\hline Bron: CPB/ETIL/ROA & & \\
\hline
\end{tabular}

Bron: CPB/ETIL/ROA

Beroepsgroepen met een relatief hoge uitbreidingsvraag in Overijssel:

- $\quad$ verpleeghulpen en leerling-verpleegkundigen

- afdelingshoofden zorginstelling

- journalisten

- weg- en waterbouwkundigen

Beroepsgroepen met een relatief lage uitbreidingsvraag in Overijssel:

- technisch systeemanalisten

- elektrotechnisch ontwerpers en bedrijfshoofden

- brandweerlieden

- werktuigbouwkundig ontwerpers en hoofden technische dienst 
beroepsgroepen met de relatief sterkste uitbreidingsvraag en de vier beroepsgroepen met de relatief geringste uitbreidingsvraag. Een bijzonder hoge uitbreidingsvraag is te vinden onder journalisten, weg- en waterbouwkundigen, afdelingshoofden zorginstelling maar ook onder de laag opgeleide verpleeghulpen en leerling-verpleegkundigen. Van een bijzonder lage uitbreidingsvraag is sprake bij werktuigbouwkundige ontwerpers, brandweerlieden, elektrotechnische ontwerpers en bedrijfshoofden, maar ook bij technische systeemanalisten. Het laatste strookt niet helemaal met de sterke uitbreidingsvraag onder IT beroepen en moet derhalve uit een verschuiving binnen de ICT beroepen verklaard worden.

\section{Opleidingssectoren}

De vraag naar werknemers in een bepaald beroep kan worden vertaald in een vraag naar mensen met een bepaalde opleidingsachtergrond. Tabel 3.3 geeft een overzicht van de verwachte uitbreidingsvraag naar opleidingssector voor Overijssel. Duidelijk is een voortgaande trend naar hoger opgeleide werknemers te zien. Negatieve uitbreidingsvraag is vooral bij lagere opleidingen te vinden, terwijl hogere opleidingen vaak een positieve uitbreidingsvraag tegemoet zien. Dit komt doordat binnen bedrijfssectoren een verschuiving plaatsvindt van laag opgeleide werknemers naar hoger opgeleide werknemers. Ook al is het hoger onderwijs sterk vertegenwoordigd in een bedrijfssector die krimpt, kan door de sterke groei van het aandeel in die sector toch een positieve uitbreidingsvraag voor het hoger onderwijs optreden. Deze algemene trend doet zich ook in Overijssel voor.

De negatieve uitbreidingsvraag voorde opleidingssector VMBO Natuur en techniek is vooral terug te vinden beide opleidingen VMBO Landbouw en VMBO Voertuigtechniek. Bij MBO Natuur en techniek vormen vooral MBO Werktuigbouw en MBO Grafische techniek negatieve uitschieters, terwijl de kleine opleiding MBO Laboratorium wel een hoge uitbreidingsvraag heeft. In het volgende kader zijn de opvallende uitkomsten per opleidingstype weergegeven. Genoemd worden de vijf sterkste en de zeven minst sterke groeiers. De hogere uitbreidingsvraag is bij opleidingen terug te vinden die een duidelijk verband met een van de groeiende bedrijfssectoren hebben. Afwijkend van de algemene trend die in de Nederlandse prognose zichtbaar is, valt de uitbreidingsvraag voor VMBO Verzorging duidelijk lager uit, evenals MBO en HBO Natuur en techniek. Voor HBO Paramedisch en WO Medisch voorspellen wij een duidelijk hogere uitbreidingsvraag. Ook de WO richtingen Economie en Letteren en Sociaal cultureel hebben een duidelijk sterkere uitbreidingsvraag ten opzichte van de landelijke ontwikkeling. Vooral de laatste groep profiteert hier van de verwachte uitbreiding van de kwartaire en overheidssector.

Zeer sterk groeiende opleidingsrichtingen zijn vooral onder de hoog opgeleiden te vinden: WO Economie, HBO Communicatie en journalistiek, Bibliotheek en documentatie zijn allemaal sterke groeiers. Deze opleidingen vertegenwoordigen slechts een zeer klein deel van de werkende Overijsselse bevolking. Grote krimp wordt voorspeld voor de lagere opleidingen VMBO Grafische techniek, Voertuigentechniek, Landbouw en natuurlijke omgeving, en Fijne mechanische techniek. Maar ook voor 
Tabel 3.3

Verwachte uitbreidingsvraag naar opleidingssector 2003-2008, Overijssel en Nederland, percentage van werkenden in 2003

\begin{tabular}{lrr}
\hline Opleidingssector & Overijssel 2003-2008 & Nederland 2003-2008 \\
\hline Basisonderwijs & -20 & -24 \\
VMBO Theorie & 5 & -1 \\
VMBO Natuur en techniek & -12 & -15 \\
VMBO Economie & 5 & 0 \\
VMBO Verzorging & 3 & 7 \\
HAVO/VWO & 15 & 9 \\
MBO Natuur en techniek & 1 & 6 \\
MBO Economie & 1 & 0 \\
MBO Dienstverlening en gezondheidszorg & 7 & 5 \\
HBO Natuur en techniek & 0 & 5 \\
HBO Economie & 4 & 5 \\
HBO Onderwijs en sociaal-cultureel & 9 & 6 \\
HBO Paramedisch & 22 & 18 \\
WO Natuur en techniek & 8 & 4 \\
WO Economie & 16 & 11 \\
WO Letteren en sociaal-cultureel & 18 & 9 \\
WO Medisch & 11 & 1 \\
Totaal & 4 & 5 \\
\hline BrOn: CPB/ETI ROA & & 5 \\
\hline
\end{tabular}

Bron: CPB/ETIL/ROA

Opleidingstypen met een relatief hoge uitbreidingsvraag in Overijssel:

- $\quad$ MBO horeca

- $\quad \mathrm{HBO}$ communicatie en journalistiek

- $\quad$ HBO bibliotheek en documentatie

- WO informatica en bestuurlijke informatiekunde

- WO econom(etr)ie

Opleidingstypen met een relatief lage uitbreidingsvraag in Overijssel:

- $\quad \mathrm{VMBO}$ grafische techniek

- $\quad \mathrm{VMBO}$ voertuigentechniek

- VMBO landbouw en natuurlijke omgeving

- VMBO fijnemechanische techniek

- $\mathrm{VMBO}$ brood en banket

- MBO verzekeringswezen

- $\quad \mathrm{HBO}$ vervoer en logistiek 
het MBO Verzekeringswezen en HBO Vervoer en logistiek verwachten wij een krimpende uitbreidingsvraag.

\subsection{Vervangingsvraag}

In deze paragraaf behandelen we de tweede vraagcomponent: de vervangingsvraag. Dit is de vraag naar arbeidskrachten welke voortvloeit uit het vertrek van werkenden. Deze werkenden kunnen om een breed scala aan redenen besluiten al dan niet tijdelijk de arbeidsmarkt te verlaten. Hierbij kan gedacht worden aan pensioen, VUT, arbeidsongeschiktheid en bijvoorbeeld zorgtaken. Andere oorzaken van vervangingsvraag zijn baan-baan mobiliteit van werkenden tussen beroepsgroepen en het volgen van cursussen of opleidingstrajecten die leiden tot verandering van de opleidingsachtergrond van werkenden. Een werkgever moet deze vertrekkende werknemers vervangen, tenzij er sprake is van een reductie van het aantal banen. Hiermee genereert een vertrekkende werknemer dus vraag naar een vervanger.

\section{Beroepsklassen}

Tabel 3.4 geeft voor Overijssel een overzicht van de verwachte vervangingsvraag per beroepsklasse op de middellange termijn. De resultaten voor Overijssel worden vergeleken met de middellange termijn prognose voor Nederland.

De vervangingsvraag wordt voor een belangrijk deel bepaald door de samenstelling van de werkende beroepsbevolking. De leeftijd- en geslachtsopbouw van de werkenden binnen een beroepsklasse zijn voor een belangrijk deel verantwoordelijk voor de verwachte uittrede uit de arbeidsmarkt. Wanneer een beroepsklasse getypeerd wordt door een groot aandeel ouderen tegen de VUT- en pensioengerechtigde leeftijd, ligt het in de lijn der verwachting dat deze beroepsklasse binnenkort veel vervangingsvraag tegemoet zal zien.

Tabel 3.4 laat de middellange termijn vervangingsvraag voor de verschillende beroepsklassen zien. Overijssel is wat de vervangingsvraag betreft redelijk vergelijkbaar met de Nederlandse situatie. Slechts de Openbare orde- en veiligheidsberoepen vertonen een duidelijk hogere vervangingsvraag. Dit is vooral aan Agenten, onderofficieren en beveiligingsemployés te danken, die ook getalsmatig een grote groep vormen. Aan der andere kant vertonen Transportberoepen en Economischadministratieve beroepen gemiddeld genomen een iets lagere vervangingsvraag. $\mathrm{Bij}$ de Transportberoepen is de lage vervangingsvraag bij de twee grootste groepen daarbinnen terug te vinden: zowel de laders en lossers als de chauffeurs hebben een lage vervangingsvraag. De economisch-administratieve beroepen hebben vooral een lage vervangingsvraag bij de grote groep van de productieplanners, boekhouders en secretaresses, en de commerciële medewerkers. 
Tabel 3.4

Verwachte vervangingsvraag naar beroepsklasse 2003-2008, Overijssel en Nederland, percentage van de werkenden in 2003

\begin{tabular}{lcc}
\hline & Overijssel & Nederland \\
& $2003-2008$ & $2003-2008$ \\
\hline Pedagogische beroepen & 22 & 22 \\
Culturele beroepen & 17 & 18 \\
Agrarische beroepen & 19 & 18 \\
Technische, ambachts- en industrieberoepen & 18 & 17 \\
Transportberoepen & 12 & 15 \\
Medische en paramedische beroepen & 17 & 18 \\
Economisch-administratieve beroepen & 14 & 16 \\
Informatica beroepen & 9 & 17 \\
Sociaal-culturele beroepen & 14 & 16 \\
Verzorgende en dienstverlenende beroepen & 16 & 16 \\
Openbare orde- en veiligheidsberoepen & 23 & 16 \\
\hline Totaal & & 16 \\
\hline Bron: ROA & & 9 \\
\hline
\end{tabular}

Bron: ROA

Beroepsgroepen met een relatief hoge vervangingsvraag in Overijssel:

- leidinggevenden

- conciërges

- politieagenten, onderofficieren en beveiligingsemployés

- docenten landbouw en techniek (2e graads)

- docenten $2 \mathrm{e}$ graads zonder specialisatie

- docenten economisch-administratieve vakken (2e graads)

Beroepsgroepen met een relatief lage vervangingsvraag in Overijssel:

- vakkenvullers

- informatici

- activiteitenbegeleiders en medewerkers arbeidsbemiddeling

- boekhouders en secretaresses

- commercieel medewerkers

- $\quad$ programmeurs 
Het kader geeft zes beroepsgroepen weer die op middellange termijn een erg hoge vervangingsvraag te verwachten hebben en zes beroepen met een te verwachten erg lage vervangingsvraag.

\section{Opleidingssector}

Vertaald naar opleidingssector is voor Overijssel een enigszins hogere vervangingsvraag te verwachten dan voor Nederland als geheel. Deze ten opzichte van de vervangingsvraag naar beroepen hogere vraag komt doordat een opscholen van werknemers automatisch als vervangingsvraag meegeteld wordt, ook al blijft deze in dezelfde beroep.

Tabel 3.5

Verwachte vervangingsvraag naar opleidingssector 2003-2008, Overijssel en Nederland, percentage van werkenden in 2003

\begin{tabular}{lcc}
\hline & Overijssel & Nederland \\
& $2003-2008$ & $2003-2008$ \\
\hline Basisonderwijs & 20 & 24 \\
VMBO Theorie & 13 & 21 \\
VMBO Natuur en techniek & 20 & 19 \\
VMBO Economie & 17 & 22 \\
VMBO Verzorging & 14 & 24 \\
HAVO/VWO & 9 & 15 \\
MBO Natuur en techniek & 18 & 19 \\
MBO Economie & 16 & 21 \\
MBO Dienstverlening en gezondheidszorg & 11 & 19 \\
HBO Natuur en techniek & 19 & 18 \\
HBO Economie & 13 & 13 \\
HBO Onderwijs en sociaal-cultureel & 20 & 22 \\
HBO Paramedisch & 18 & 17 \\
WO Natuur en techniek & 17 & 18 \\
WO Economie & 13 & 15 \\
WO Letteren en sociaal-cultureel & 19 & 20 \\
WO Medisch & 27 & 19 \\
& & \\
Totaal & 20 & 19 \\
\hline Bro: ROA & & \\
\hline
\end{tabular}

Bron: ROA

In het volgende kader is een aantal opleidingstypen weergegeven met relatief veel (zes) of weinig (drie) vervangingsvraag in Overijssel. Hier zijn onder de opleidingen met lage vervangingsvraag vooral opleidingen te vinden die een jonge leeftijdsopbouw hebben. WO Bedrijfskunde en HBO Verpleegkunde zijn studies die vooral in de laatste jaren veel afstudeerders op de arbeidsmarkt afgeleverd hebben. Derhalve is hun participatie hoog. Aan de andere kant van het spectrum zijn de VMBO opleidingen voor Mechanische techniek, Elektrotechniek en Voertuigentechniek te 
vinden die allen een lagere participatie vertonen, onder meer door de leeftijdsopbouw maar ook door de algemeen lagere participatiegraden onder lager opgeleiden. Ook de HBO Lerarenopleiding economie en maatschappij vertoont een hoge vervangingsvraag door de relatief oude werknemers met deze opleiding.

Opleidingstypen met een relatief hoge vervangingsvraag in Overijssel:

- $\quad \mathrm{HBO}$ lerarenopleiding economie en maatschappij

- HBO lerarenopleiding expressie

- VMBO consumptief en levensmiddelentechniek

- VMBO mechanische techniek

- VMBO elektrotechniek

- $\quad$ VMBO voertuigentechniek

Opleidingstypen met een relatief lage vervangingsvraag in Overijssel:

- WO bedrijfskunde

- $\quad \mathrm{HBO}$ verpleegkunde

- $\mathrm{MBO}$ procestechniek

\subsection{Baanopeningen}

Wanneer we de prognoses van de positieve uitbreidingsvraag en de vervangingsvraag optellen, dan geeft dit een indicatie van de totale verwachte vraag voor nieuwkomers op de arbeidsmarkt: de baanopeningen. Bij krimpende werkgelegenheid - dus negatieve uitbreidingsvraag - bestaan de baanopeningen alleen uit de vervangingsvraag. D.w.z. voorzover de uitstroom althans uitgaat boven de eventuele negatieve uitbreidingsvraag in het beroep. Het vertrek van werkenden draagt dan toch bij aan het aantal baanopeningen dat door nieuwkomers vervuld kan worden.

\section{Beroepsklassen}

Tabel 3.6 geeft een overzicht van de baanopeningen (als jaarlijks groeipercentage van de werkgelegenheid) naar beroepsklasse voor Overijssel. De combinatie van uitbreidingsvraag en vervangingsvraag leidt op de middellange termijn in Overijssel tot relatief meer baanopeningen dan in Nederland. Gezien de sterkere werkgelegenheidsgroei en de slechts weinig lagere vervangingsvraag is dit beeld ook te verwachten. 
Tabel 3.6

Verwachte baanopeningen naar beroepsklasse 2003-2008, Overijssel en Nederland, percentage van werkenden in 2003

Overijssel 2003-2008 Nederland 2003-2008

Pedagogische beroepen

27

Culturele beroepen

Agrarische beroepen

Technische, ambachts- en industrieberoepen

Transportberoepen

Medische en paramedische beroepen

Economisch-administratieve beroepen

Informatica beroepen

Sociaal-culturele beroepen

Verzorgende en dienstverlenende beroepen

Openbare orde- en veiligheidsberoepen

Totaal

\section{Bron: ROA}

\section{Figuur 3.7}

Aandeel positieve uitbreidingsvraag en vervangingsvraag in de totale vraag, 2003-2008, Overijssel

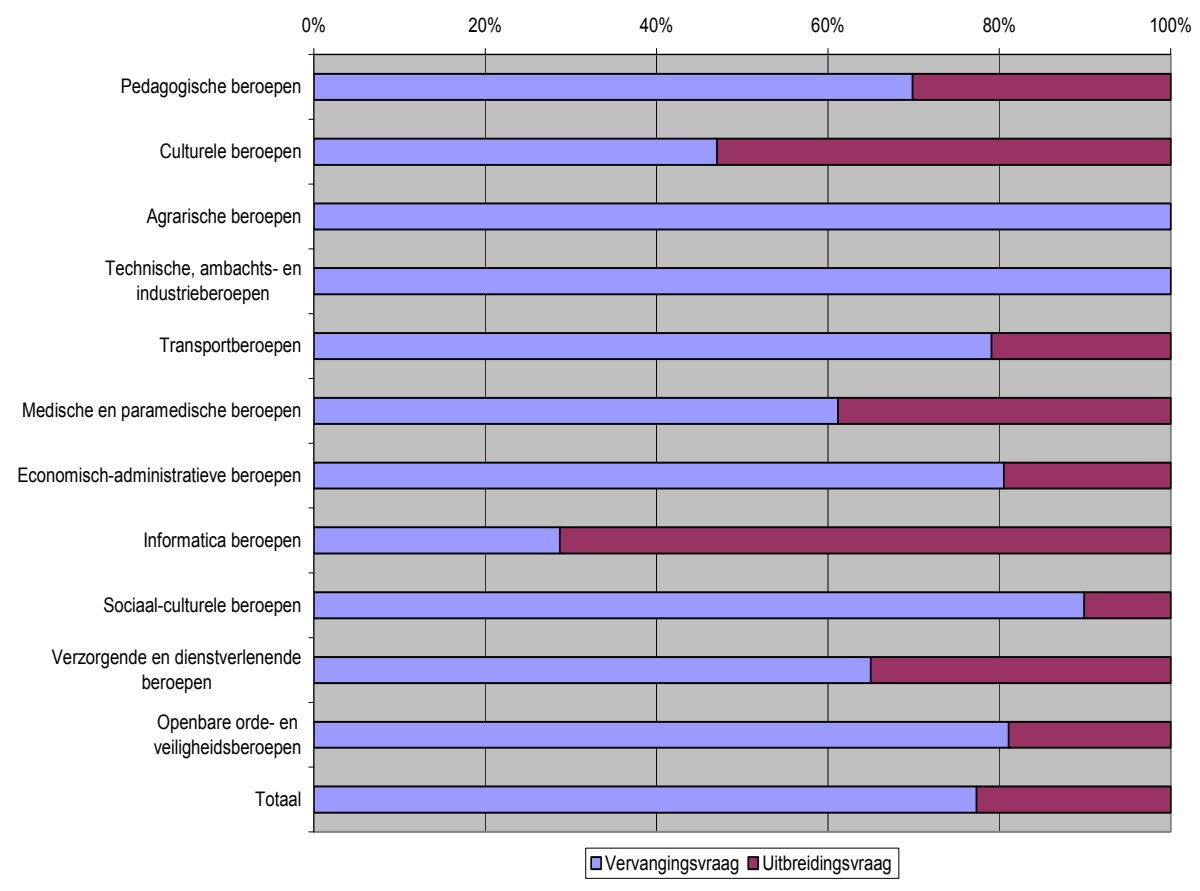

Bron: ROA 
Voor sommige beroepsklassen vormt de uitbreidingsvraag de voornaamste bron van vraag naar nieuwe arbeidskrachten, voor andere is juist de vervangingsvraag meer van belang. Figuur 3.7 geeft voor Overijssel per beroepsklasse het aandeel in de verwachte baanopeningen weer van de uitbreidingsvraag en de vervangingsvraag.

Gemiddeld genomen is de vervangingsvraag de belangrijkste component van de vraag naar nieuwe arbeidskrachten per beroep. Over alle beroepsklassen gezien is het aandeel van de vervangingsvraag meer dan driekwart van de baanopeningen. In sommige beroepen zijn de baanopeningen volledig terug te voeren op de vervangingsvraag, omdat de uitbreidingsvraag negatief is. Maar er zijn ook beroepsklassen waarvan de baanopeningen sterk beïnvloed worden door de uitbreidingsvraag. De informaticaberoepen - die een hoge uitbreidingsvraag hebben - ontlenen meer dan tweederde van hun baanopeningen aan de uitbreidingsvraag. Dit komt ook doordat de vervangingsvraag voor deze beroepen tamelijk laag is: jongere werknemers zijn in de IT beroepen ingestroomd en hebben een hogere participatiegraad dan in beroepsklassen waar een redelijk oud werknemerbestand te vinden is.

In het volgende kader staan voor Overijssel de zes beroepsgroepen met de relatief hoogste en de drie beroepsgroepen met de laagste percentages baanopeningen op middellange termijn.

Beroepsgroepen met relatief hoog percentage baanopeningen in Overijssel:

- onderwijskundig medewerkers

- kunstenaars

- $\quad$ verpleeghulpen en leerling-verpleegkundigen

- journalisten

- organisatiedeskundigen

- afdelingshoofden zorginstelling

- weg- en waterbouwkundigen

Beroepsgroepen met relatief laag percentage baanopeningen in Overijssel:

- economen

- $\quad$ activiteitenbegeleiders en medewerkers arbeidsbemiddeling

- ondersteunende administratieve hulpkrachten 


\section{Opleidingssectoren}

Ook naar opleidingsniveau zien de toekomstige baanopeningen in Overijssel er qua omvang tamelijk goed uit. Zij zijn redelijk vergelijkbaar met de situatie in Nederland. De verwachtingen voor Overijssel zijn zelfs enigszins gunstiger dan voor Nederland als geheel. Mede dankzij de positievere uitbreidingsvraag wordt de iets geringere vervangingsvraag in Overijssel ruimschoots gecompenseerd. In tabel 3.7 staan de verwachte baanopeningen naar opleidingssector voor Overijssel op de middellange termijn weergegeven als percentage van de werkgelegenheid.

In figuur 3.9 staat het relatieve aandeel van de (positieve) uitbreidingsvraag en de vervangingsvraag in de uiteindelijke baanopeningen weergegeven. Voor de meeste opleidingssectoren geldt hetzelfde als voor de totale arbeidsmarkt: de vervangingsvraag vormt de voornaamste bron van de vraag naar nieuwe arbeidskrachten. Zoals te verwachten was, is - met uitzondering van VMBO Verzorging - voor de laagste (VMBO) opleidingen de toekomstige uitbreidingsvraag minder belangrijk voor het aantal baanopeningen. Vooral onder de hoger opgeleiden is sprake van een groot aandeel van de uitbreidingsvraag, zodat vooral deze component bijdraagt aan de toekomstige baanopeningen.

Tabel 3.7

Verwachte baanopeningen naar opleidingssector 2003-2008, Overijssel en Nederland, percentage van de werkenden in 2003

Overijssel 2003-2008 Nederland 2003-2008

\begin{tabular}{lll}
\hline Basisonderwijs & 27 & 26 \\
VMBO Theorie & 31 & 21 \\
VMBO Natuur en techniek & 27 & 19 \\
VMBO Economie & 36 & 30 \\
VMBO Verzorging & 24 & 24 \\
HAVO/VWO & 32 & 24 \\
MBO Natuur en techniek & 24 & 26 \\
MBO Economie & 23 & 23 \\
MBO Dienstverlening en gezondheidszorg & 25 & 26 \\
HBO Natuur en techniek & 21 & 24 \\
HBO Economie & 18 & 17 \\
HBO Onderwijs en sociaal-cultureel & 29 & 29 \\
HBO Paramedisch & 36 & 34 \\
WO Natuur en techniek & 21 & 22 \\
WO Economie & 28 & 25 \\
WO Letteren en sociaal-cultureel & 38 & 29 \\
WO Medisch & 34 & 19 \\
Totaal & 26 & 24 \\
\hline B
\end{tabular}


Figuur 3.9

Aandeel uitbreidingsvraag en vervangingsvraag in de totale vraag, 2003-2008, Overijssel

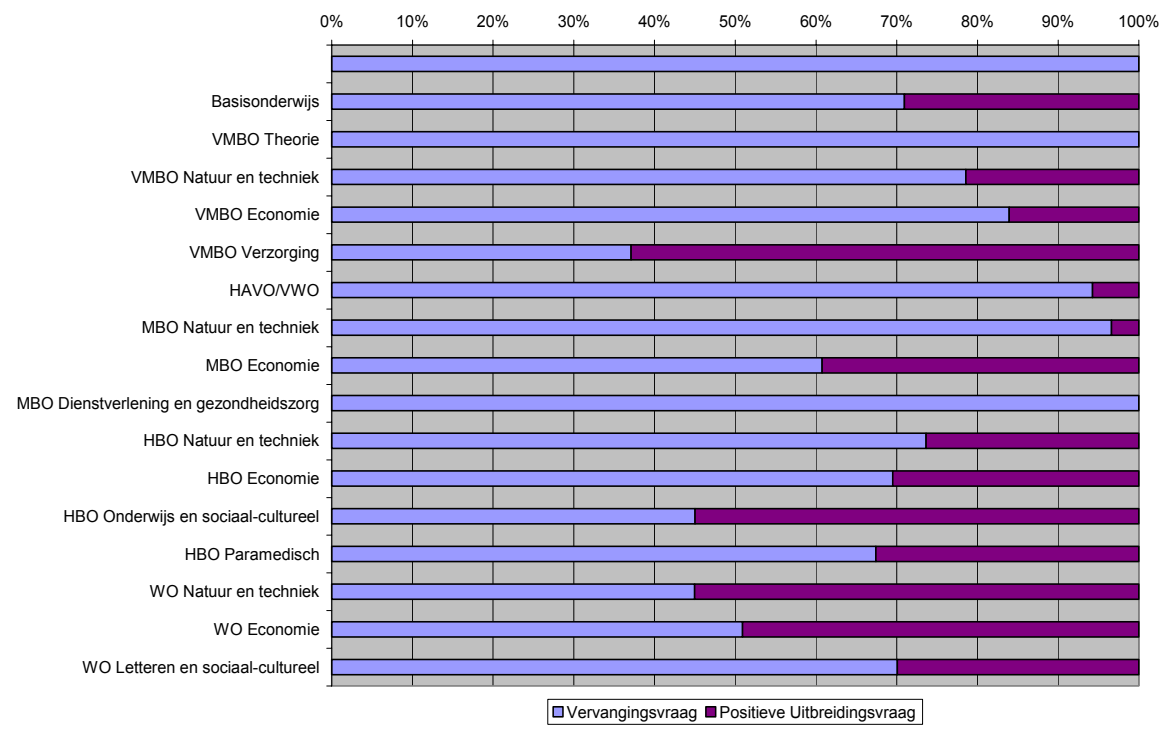

Bron: ROA

Opleidingstypen met een relatief hoog percentage baanopeningen in Overijssel:

- WO tandheelkunde

- WO econom(etr)ie

- $\mathrm{HBO}$ bibliotheek en documentatie

- $\quad$ MBO horeca

Opleidingstypen met een relatief laag percentage baanopeningen in Overijssel:

- WO werktuigbouwkunde

- WO theologie

- WO elektrotechniek

- WO bedrijfskunde

- $\mathrm{HBO}$ vervoer en logistiek

- HBO milieukunde en levensmiddelentechnologie

- HBO commerciële economie

- $\mathrm{MBO}$ fijnmechanische techniek 
In het kader staan beroepen en opleidingen met relatief hoge of relatief lage percentages baanopeningen voor Overijssel. De verzameling opleidingstypen in dit kader is redelijk divers. Interessant onder deze opleidingen met hoge of juist lage percentages aan baanopeningen is de universitaire economieopleiding. Deze wordt met een hoog percentage baanopeningen aangegeven, terwijl in het voorgaande kader ten aanzien van het beroep economen schijnbaar het tegendeel beweerd werd. Zij werden immers als beroep met een lage baanopening gekarakteriseerd. Maar werknemers met een economisch wetenschappelijke opleiding hoeven niet als econoom te werken. Zij zijn in een groot aantal beroepen werkzaam waarvan er velen een hoge baanopening hebben. $E r$ is dus vaak geen directe één-op-één relatie tussen beroep en opleiding. 



\section{$4 \quad$ Verwachte knelpunten en perspectieven op de arbeidsmarkt voor schoolverlaters}

Ten aanzien van de aansluiting tussen onderwijs en arbeidsmarkt vormen de arbeidsmarktperspectieven voor schoolverlaters en de knelpunten in de personeelsvoorziening voor werkgevers elkaars tegenhanger. ${ }^{10}$ Zijn de arbeidsmarktvooruitzichten voor schoolverlaters bijvoorbeeld goed dan zullen werkgevers grote knelpunten ondervinden bij de werving van jongeren. Uit de prognoses tot 2008 blijkt dat de perspectieven voor schoolverlaters alleen goed zijn voor de opleidingssectoren VMBO Theorie en MBO Natuur en techniek. De keerzijde van de gunstige perspectieven voor deze opleidingssectoren is bijgevolg dat werkgevers op de middellange termijn knelpunten zullen ondervinden bij het aantrekken van schoolverlaters uit deze sectoren.

Bij het bepalen van de arbeidsmarktvooruitzichten voor schoolverlaters worden de vraagcomponenten (uitbreidingsvraag en vervangingsvraag) en de aanbodcomponenten (uitstroom uit opleidingen en kortdurend werklozen) met elkaar geconfronteerd. De totale vraag naar schoolverlaters blijkt voor de VMBO-opleidingssectoren vooral bepaald te worden door het hoge aandeel van de vervangingsvraag in de baanopeningen, terwijl voor de MBO-opleidingssectoren ook de uitbreidingsvraag bijdraagt aan de totale vraag. Als men de prognoses van beide vraagcomponenten confronteert met het aanbod van schoolverlaters dat verwacht wordt, blijkt dat voor de sectoren economie en verzorging op zowel VMBO als MBO niveau het aanbod van schoolverlaters de verwachte baanopeningen overstijgt. Hierdoor zullen schoolverlaters met een dergelijke opleidingsachtergrond in de toekomst problemen ondervinden bij het vinden van een geschikte baan.

Werkgevers kunnen tot 2008, door de lage instroom van schoolverlaters, grote knelpunten in de personeelsvoorziening verwachten bij onder andere de Pedagogische beroepen. Bij deze beroepen zijn bovendien de mogelijkheden voor werkgevers beperkt om schoolverlaters aan te trekken met een andere dan de meest geëigende opleidingsachtergrond. Bij de Culturele beroepen, de Technische en industrieberoepen, Medische en paramedische beroepen, de Informaticaberoepen en de Openbare orde en veiligheidsberoepen worden ook grote knelpunten in de personeelsvoorziening verwacht.

Vrijwel geen knelpunten in de personeelsvoorziening worden verwacht bij de Agrarische beroepen en de Verzorgende en dienstverlenende beroepen. Deze voor

10. De opleidingen van het HBO en het WO blijven hier buiten beschouwing, omdat de arbeidsmarktperspectieven voor deze opleidingen vooral bepaald worden door het landelijke beeld (zie ook hoofdstuk 3). Dit hangt samen met het gegeven dat de instroom van afgestudeerden van het hoger onderwijs op de arbeidsmarkt een grote geografische mobiliteit vertoont. Zie voor de landelijke arbeidsmarktperspectieven voor HBO- en WOopleidingen (ROA, 2003), De arbeidsmarkt naar opleiding en beroep tot 2008, ROA-R2003/11, Maastricht. 
werkgevers gunstige situatie wordt veroorzaakt door het krimpen van de werkgelegenheid voor de Agrarische beroepen, tezamen met een relatief lage vervangingsvraag vergeleken met de instroom van schoolverlaters.

\subsection{Inleiding}

In dit hoofdstuk wordt ingegaan op de middellangetermijnprognoses van de perspectieven en knelpunten op de Overijsselse arbeidsmarkt tot 2008. De verwachte ontwikkelingen met betrekking tot de uitbreidingsvraag, vervangingsvraag, baanopeningen en instroom van schoolverlaters zijn al besproken in het voorgaande hoofdstuk. In dit hoofdstuk zal de nadruk liggen op de arbeidsmarktvooruitzichten voor schoolverlaters en de verwachte knelpunten in de personeelsvoorziening voor werkgevers. Dit houdt in dat de vraag- en aanbodcomponenten met elkaar worden geconfronteerd.

De toekomstige arbeidsmarktperspectieven voor schoolverlaters worden besproken aan de hand van de Indicator Toekomstperspectieven op de Arbeidsmarkt (ITA). De ITA geeft aan wat voor schoolverlaters en andere werkzoekenden de kansen zijn op de arbeidsmarkt. Een ITA die groter is dan één geeft een ongunstige arbeidsmarkt weer voor schoolverlaters en werkzoekenden. Indien de ITA namelijk groter is dan één, is er meer aanbod van arbeid dan vraag en is er dus sprake van een overschot aan arbeidskrachten. Bij een ITA kleiner dan één is er sprake van een gunstige arbeidsmarkt voor schoolverlaters en werkzoekenden. Het aanbod van werkenden is dan kleiner dan de vraag.

Voor werkgevers is het van belang een indicatie te krijgen van de toekomstige knelpunten in de personeelsvoorziening in de beroepssector waarvoor ze personeel werven. Als er voor bepaalde sectoren tekorten aan personeel worden verwacht kunnen zij tijdig besluiten hun personeel elders te werven of door preventief arbeidsmarktbeleid de instroom van schoolverlaters te vergroten. De knelpunten in de personeelsvoorziening zullen worden besproken aan de hand van de Indicator Toekomstige Knelpunten op de arbeidsmarkt naar Beroep (ITKB). Deze geeft aan in welke mate het voor werkgevers mogelijk is om binnen een beroepsgroep de gewenste personeelssamenstelling naar opleidingsachtergrond te realiseren. Hierbij wordt rekening gehouden met de vraag- aanbod verhoudingen voor de verschillende opleidingstypen. De ITKB heeft een waarde tussen nul en één. Naarmate de indicator lager is, zijn de knelpunten groter voor de opleidingstypen die voor de betreffende beroepsgroep relevant zijn. De werkgevers zullen dan problemen ondervinden bij het aantrekken van dit type personeel. Wanneer de ITKB echter dicht bij één ligt, zullen werkgevers weinig moeite hebben de gewenste personeelssamenstelling te realiseren.

$\mathrm{Bij}$ een aanbodoverschot is het niet vanzelfsprekend dat schoolverlaters werkloos worden, evenals dat het bij een vraagoverschot niet vanzelfsprekend is dat er onvervulde vacatures zijn. Het is namelijk ook mogelijk dat werkgevers hun eisen aanpassen aan de arbeidsmarktsituatie op dat moment. Bij een vraagoverschot op 
specifieke opleidingssegmenten kunnen werkgevers ook personeel werven dat niet volledig beschikt over de benodigde kwalificaties. Deze mensen moeten dan wel omof bijgeschoold worden om aan de kwalificatievereisten voor deze banen te voldoen.

De opzet van dit hoofdstuk is als volgt: In paragraaf 4.2 worden de middellangetermijnperspectieven naar opleidingssector gepresenteerd. Vervolgens worden in paragraaf 4.3 de toekomstige knelpunten in de personeelsvoorziening besproken. In paragraaf 4.4 wordt ingegaan op de uitwijkmogelijkheden voor schoolverlaters in combinatie met hun arbeidsmarktperspectieven. Daarna komen de substitutiemogelijkheden voor werkgevers aan de orde, welke in verband worden gebracht met de toekomstige knelpunten in de personeelsvoorziening.

\subsection{De arbeidsmarktperspectieven voor schoolverlaters}

In tabel 4.1 wordt voor Overijssel de Indicator Toekomstig Arbeidsmarktperspectief (ITA) gepresenteerd voor de lagere en middelbare opleidingssectoren. De aangegeven typeringen hebben de volgende betekenis. Als het arbeidsaanbod kleiner is dan de vraag en rekeninghoudend met de aanwezigheid van fricties (ITA kleiner of gelijk aan 1,04) wordt het arbeidsmarktperspectief als redelijk, goed of zeer goed getypeerd. Als daarentegen het aanbod de vraag overtreft (ITA groter dan 1,04), wordt het arbeidsmarktperspectief als matig, slecht of zeer slecht getypeerd. Als de arbeidsmarktperspectieven voor schoolverlaters en werkzoekenden gunstig zijn, zullen zij relatief gemakkelijk een baan vinden in de beroepsgroep waarvoor hun opleidingsachtergrond vereist is. Voor werkgevers daarentegen zal het dan juist moeilijk zijn om schoolverlaters met deze opleidingsachtergrond aan te trekken. Een bijvoorbeeld als 'goed' getypeerd arbeidsmarktperspectief voor schoolverlaters en werkzoekenden zal dus doorgaans samenvallen met grote knelpunten in de personeelsvoorziening voor werkgevers.

Tabel 4.1 laat zien dat in Overijssel op de middellange termijn de arbeidsmarktperspectieven voor de schoolverlaters van de lagere opleidingen over het algemeen wisselend zijn. Met name schoolverlaters van de opleidingsrichtingen VMBO Economie, VMBO Verzorging, MBO Dienstverlening en gezondheidszorg en HAVO/ VWO kunnen problemen verwachten bij het vinden van een geschikte baan. De matige middellangetermijnperspectieven voor deze opleidingssectoren worden veroorzaakt door de hoge instroom van schoolverlaters. Het aantal baanopeningen weegt onvoldoende op tegen de arbeidsmarktinstroom van schoolverlaters.

Alleen de schoolverlaters met een opleiding binnen VMBO Theorie en MBO Natuur en techniek hebben gunstige arbeidsmarktvooruitzichten. De keerzijde van de matige toekomstperspectieven voor meerdere opleidingssectoren is dat werkgevers voor deze sectoren minder knelpunten in de personeelsvoorziening zullen ondervinden.

De Overijsselse arbeidsmarktvooruitzichten voor schoolverlaters verschillen nogal van de vooruitzichten voor de Nederlandse arbeidsmarkt. Vergeleken met Nederland zijn de arbeidsmarktperspectieven voor Overijsselse schoolverlaters meestal gun- 
stiger. Met name schoolverlaters met VMBO Theorie en VMBO Natuur en techniek hebben in Overijssel een grotere kans om een baan te vinden dan elders in Nederland. Schoolverlaters in Overijssel met MBO Dienstverlening en gezondheidszorg kunnen misschien beter ook buiten de provincie een baan zoeken omdat de arbeidsmarktperspectieven elders in Nederland gunstiger zijn.

Tabel 4.1

Indicator Toekomstige Arbeidsmarktperspectieven (ITA) per opleidingssector tot 2008, Overijssel en Nederland

\begin{tabular}{lrrrrr}
\hline & \multicolumn{2}{c}{ Overijssel } & \multicolumn{2}{c}{ Nederland } \\
Opleidingssector & ITA & Typering & ITA & typering \\
& & & & & \\
\hline Basisonderwijs & 1,02 & Redelijk & 1,11 & Matig \\
VMBO Theorie & 0,97 & Goed & 1,13 & Matig \\
VMBO Natuur en techniek & 1,01 & Redelijk & 1,16 & Slecht \\
VMBO Economie & 1,10 & Matig & 1,29 & Slecht \\
VMBO Verzorging & 1,08 & Matig & 1,19 & Slecht \\
HAVO/VWO & 1,06 & Matig & 1,14 & Matig \\
MBO Natur en techniek & 0,98 & Goed & 1,00 & Goed \\
MBO Economie & 1,01 & Redelijk & 1,06 & Matig \\
MBO Dienstverlening en gezondheidszorg & 1,05 & Matig & 1,05 & Redelijk \\
& & & & & \\
\hline
\end{tabular}

Bron: ROA

\section{De opleidingen met de beste en slechtste arbeidsmarktvooruitzichten}

De arbeidsmarktperspectieven van opleidingssectoren op de middellange termijn zoals beschreven in tabel 4.1, worden in onderstaand kader verbijzonderd naar opleidingstype. Het kader beperkt zich tot de zes opleidingstypen met de meest gunstige arbeidsmarktvooruitzichten en de zes opleidingstypen met de meest ongunstige vooruitzichten. Zo blijkt dat de goede arbeidsmarktperspectieven voor de opleidingssectoren MBO Natuur en techniek betrekking hebben op de onderliggende opleidingstypen MBO bouw, MBO installatietechniek, MBO operationele techniek en MBO laboratorium. De goede arbeidsmarktperspectieven voor deze opleidingstypen worden met name veroorzaakt door de qua omvang gemiddelde instroom van schoolverlaters vergeleken met het grote aantal baanopeningen.

Matige arbeidsmarktperspectieven worden verwacht voor de VMBO opleidingssectoren VMBO Economie, VMBO Verzorging en HAVO/VWO. Voor VMBO Economie zijn deze ongunstige arbeidsmarktperspectieven terug te vinden bij het onderliggende opleidingstype VMBO administratie, handel en mode. Voor MBO Dienstverlening en gezondheidszorg zijn de ongunstige arbeidsmarktperspectieven te vinden bij MBO gezondheidstechniek en MBO facilitaire dienstverlening. Ondanks het hoge aantal baanopeningen worden voor deze opleidingstypen matige perspectieven verwacht door de nog hogere instroom van schoolverlaters. 
Opleidingstypen met gunstige arbeidsmarktperspectieven voor schoolverlaters en werkzoekenden in Overijssel tot 2008:

- $\quad \mathrm{VMBO}$ brood en banket

- $\mathrm{MBO}$ apothekersassistent

- MBO installatietechniek

- $\mathrm{MBO}$ operationele techniek

- MBO bouw

- $\mathrm{MBO}$ laboratorium

Opleidingstypen met ongunstige arbeidsmarktperspectieven voor schoolverlaters en werkzoekenden in Overijssel tot 2008:

- VMBO fijnmechanische techniek

- VMBO administratie, handel en mode

- $\mathrm{MBO}$ gezondheidstechniek

- MBO grond-, weg- en waterbouw

- $\mathrm{MBO}$ facilitaire dienstverlening

- $\mathrm{MBO}$ fijnmechanische techniek

Voorts blijkt dat ook al zijn de arbeidsmarktperspectieven voor de opleidingssector MBO Dienstverlening en gezondheidszorg matig, er toch nog onderliggende opleidingstypen zijn die gunstige perspectieven kunnen verwachten. Met name schoolverlaters van het opleidingstype MBO apothekersassistent kunnen in Overijssel op de middellange termijn gunstige arbeidsmarktperspectieven verwachten. Het omgekeerde geldt voor de opleidingssector MBO Natuur en techniek waarvoor gunstige arbeidsmarktperspectieven voor schoolverlaters voorspeld worden. Twee onderliggende opleidingstypen van de sector MBO Natuur en techniek, te weten MBO grond-, weg- en waterbouw en MBO fijnmechanische techniek hebben arbeidsmarktperspectieven die aanmerkelijk minder gunstig zijn dan voor de andere opleidingstypen binnen deze sector.

\subsection{Knelpunten in de personeelsvoorziening voor werkgevers}

Werkgevers zullen om het personeelsbeleid voor hun organisatie nader te kunnen invullen, willen weten waar de baanopeningen in de toekomst zullen gaan optreden. In eerste instantie zullen zij grotere of kleinere knelpunten ondervinden voor het vervullen van bepaalde functies. Op deze functies kunnen echter vaak schoolverlaters en werkzoekenden met een uiteenlopende opleidingsachtergrond worden ingezet. De Indicator Toekomstige Knelpunten in de personeelsvoorziening naar 
Beroep (ITKB) houdt rekening met de verwachte schaarste op de arbeidsmarkt van de verschillende relevante opleidingstypen voor een beroep. Indien er een sterke één-op-één relatie is tussen opleiding en beroep, zoals in de zorg en het onderwijs, komt de verwachte vraag-aanbod verhouding voor deze opleidingen uiteraard grotendeels overeen met die voor de desbetreffende beroepen. De strategieën voor werkgevers om de tekorten op te vangen zijn beperkt als de substitutiemogelijkheden tussen schoolverlaters met een uiteenlopende opleidingsachtergrond gering zijn. De opleidingsvereisten in met name de zorg en het onderwijs liggen in belangrijke mate vast, waardoor werkgevers op dit punt weinig flexibel kunnen zijn in hun aannamebeleid.

Tabel 4.2 geeft de ITKB per beroepsklasse met bijbehorende typeringen weer voor zowel Overijssel als Nederland. Hieruit blijkt dat in Overijssel de knelpunten in de personeelsvoorziening op de middellange termijn groot zullen zijn bij de Pedagogische beroepen, Culturele beroepen, Technische en industrieberoepen, Informaticaberoepen en de Openbare orde en veiligheidsberoepen. Vergeleken met Nederland zullen de knelpunten in Overijssel over het algemeen groter zijn. Met name voor werkgevers in de Culturele beroepen, Technische en industrieberoepen en Informaticaberoepen zal het vinden van geschikt personeel in Overijssel moeizamer gaan dan in de rest van Nederland. In de Sociaal-culturele beroepen zullen de knelpunten voor Overijsselse werkgevers echter kleiner zijn dan landelijk gezien.

Tabel 4.2

Indicator Toekomstige Knelpunten in de personeelsvoorziening naar Beroep (ITKB) per beroepsklasse tot 2008, Overijssel en Nederland

Beroepsklasse $\quad$ ITKB $r$ typering $\quad \begin{gathered}\text { Nederland } \\ \text { typering }\end{gathered}$

$\begin{array}{lccc}\text { Pedagogische beroepen } & 0,89 & \text { Groot } & \text { Groot } \\ \text { Culturele beroepen } & 0,89 & \text { Groot } & \text { Enige } \\ \text { Agrarische beroepen } & 0,97 & \text { Vrijwel geen } & \text { Geen } \\ \text { Technische en industrie beroepen } & 0,90 & \text { Groot } & \text { Vrijwel geen } \\ \text { Transportberoepen } & 0,95 & \text { Vrijwel geen } & \text { Geen } \\ \text { Medische en paramedische beroepen } & 0,90 & \text { Groot } & \text { Groot } \\ \text { Economisch-administratieve beroepen } & 0,94 & \text { Enige } & \text { Enige } \\ \text { Informaticaberoepen } & 0,91 & \text { Groot } & \text { Enige } \\ \text { Sociaal-culturele beroepen } & 0,93 & \text { Enige } & \text { Groot } \\ \text { Verzorgende en dienstverlenende beroepen } & 0,96 & \text { Vrijwel geen } & \text { Geen } \\ \text { Openbare orde- en veiligheidsberoepen } & 0,90 & \text { Groot } & \text { Groot }\end{array}$

Note: Omdat de ITKB voor Nederland op een andere manier berekend wordt dan voor Overijssel, zijn de getallen niet direct vergelijkbaar. Daarom worden voor Nederland Bron: ROA geen ITKB's weergegeven.

De knelpunten bij de Pedagogische beroepen in Overijssel worden veroorzaakt door de zeer lage instroom van schoolverlaters. Met name de relatief oude beroepsbevolking leidt bij de Pedagogische beroepen tot veel vervangingsvraag. Doordat de verwachte instroom van schoolverlaters deze vervangingsvraag niet kan bijbenen, 
ontstaan er grote knelpunten. Bij de Pedagogische beroepen speelt bovendien een rol dat de substitutiemogelijkheden voor werkgevers beperkt zijn. Bij de Culturele beroepen, Technische en industrieberoepen, Informaticaberoepen en de Openbare orde en veiligheidsberoepen worden ook grote knelpunten verwacht.

Vrijwel geen knelpunten in de personeelsvoorziening worden met name verwacht bij de Agrarische beroepen, Transportberoepen en Verzorgende en dienstverlenende beroepen. Deze gunstige situatie voor de werkgevers wordt veroorzaakt door het krimpen van de werkgelegenheid voor de Agrarische beroepen, tezamen met een relatief lage vervangingsvraag vergeleken met de instroom van schoolverlaters. Voor de Transportberoepen en de Verzorgende en dienstverlenende beroepen geldt dat de werkgelegenheid over het algemeen niet daalt, maar dat het aantal baanopeningen toch niet toereikend is voor de relatief grote instroom van schoolverlaters.

\section{De kleinste en grootste knelpunten naar beroep}

Aan de hand van de scores op de indicator voor te verwachten knelpunten in de personeelsvoorziening binnen de verschillende beroepsklassen kunnen de knelpunten voor de onderliggende beroepsgroepen bekeken worden. Uit tabel 4.2 is bijvoorbeeld gebleken dat op de middellange termijn grote knelpunten verwacht kunnen worden bij de Pedagogische beroepen. Echter, niet alle werkgevers die een vacature open hebben staan in deze beroepsklasse zullen geconfronteerd worden met knelpunten in de personeelsvoorziening. Aangezien de vooruitzichten voor een beroepsklasse niet identiek zijn voor alle onderliggende beroepsgroepen wordt in onderstaand schema een overzicht gegeven van de zes beroepsgroepen waarvoor Overijsselse werkgevers relatief veel knelpunten in de personeelsvoorziening kunnen verwachten en de zes beroepsgroepen waarvoor zij relatief weinig knelpunten kunnen verwachten.

Binnen de Pedagogische beroepen worden de grote rekruteringsproblemen niet door één of meer onderliggende beroepsgroepen veroorzaakt, maar zijn voor alle onderliggende beroepsgroepen grote tot zeer grote rekruteringsproblemen te verwachten. $\mathrm{Bij}$ de Technische en industrieberoepen worden de grote rekruteringsproblemen met name veroorzaakt door de onderliggende beroepsgroepen aannemers en installateurs, architecten en bouwkundige projectleiders, weg- en waterbouwkundige vakkrachten en door de monteurs. Ondanks de daling van de werkgelegenheid die verwacht wordt bij deze beroepsgroepen zorgt de hoge vervangingsvraag voor problemen bij de rekrutering. Rekruteringsproblemen zullen optreden bij de leraren Basisonderwijs. Dit wordt veroorzaakt door de relatief hoge uitbreidingsvraag. Voor werkgevers die op zoek zijn naar leraren Basisonderwijs geldt dat de toename van de werkgelegenheid te groot is om alle baanopeningen te kunnen vervullen. 
Beroepsgroepen met relatief veel rekruteringsproblemen voor werkgevers in Overijssel tot 2008:

- hoofden technische dienst

- docenten economisch-administratieve vakken (1e graads)

- bibliothecarissen

- weg- en waterbouwkundigen

- docenten sociale vakken (1e graads)

Beroepsgroepen met relatief weinig rekruteringsproblemen voor werkgevers in Overijssel tot 2008:

- confectie-arbeiders

- verpleeghulpen en leerling-verpleegkundigen

- interieurverzorgers

- $\quad$ agrarische hulparbeiders

- landbouwmachinebestuurders en vissers

- $\quad$ vakkenvullers

Op de middellange termijn worden geen rekruteringsproblemen verwacht voor de beroepsgroep vakkenvullers, welke gekenmerkt wordt door een (zeer) lage vervangingsvraag. Werkgevers die mensen zoeken voor een baan als verpleeghulpen en leerling-verpleegkundigen zullen naast een stijging van de werkgelegenheid ook te maken krijgen met een gemiddelde vervangingsvraag. Toch zijn er relatief weinig rekruteringsproblemen te verwachten doordat de instroom van schoolverlaters en werkzoekenden deze vraag teniet zullen doen.

Weinig rekruteringsproblemen worden onder andere ook verwacht voor de beroepsgroepen interieurverzorgers, landbouwmachinebestuurders, agrarische hulparbeiders en confectiearbeiders. Dit wordt veroorzaakt door de combinatie van krimp in de werkgelegenheid en gemiddelde instroom van schoolverlaters bij deze beroepsgroepen. De gemiddelde instroom van schoolverlaters is hier groter dan het aantal baanopeningen waardoor werkgevers weinig moeite hoeven te doen om een geschikte kandidaat te vinden.

\subsection{Uitwijk- en substitutiemogelijkheden op de arbeidsmarkt}

De uitwijkmogelijkheden die schoolverlaters kunnen benutten om in slechte tijden te switchen van baan houden verband met de structurele positie van opleidingen. Opleidingen beschikken namelijk over een bepaald curriculum dat kan variëren van een smal en specialistisch vakgebied tot een breed en algemeen gericht studie- 
programma. Verandering van deze 'arbeidsmarktscope' van het curriculum, bijvoorbeeld een verbreding van de opleiding, geeft toegang tot een breder beroependomein. Door deze verbreding wordt de kwetsbaarheid voor specifieke beroepsontwikkelingen verminderd en daarmee de conjunctuurgevoeligheid van de desbetreffende opleiding. Een nadeel van verbreding van een opleiding is het mogelijk verlies aan productiviteit in het beroep ten opzichte van een smalle gespecialiseerde opleiding. Het kan vanuit arbeidsmarktoogpunt overigens efficiënt zijn om voor een beroependomein een kern van specialisten te hebben naast een periferie van breed opgeleiden die door hun grote uitwijkmogelijkheden als conjunctuurbuffer kunnen fungeren. Er kan dus wel degelijk behoefte zijn aan specifiek opgeleid personeel, zodat het wenselijk is dat onderwijsinstellingen tevens specialistische opleidingen aanbieden.

In deze paragraaf wordt voor de Overijsselse arbeidsmarkt een overzicht gegeven van de arbeidsmarktkansen voor schoolverlaters van de onderscheiden opleidingstypen op VMBO- en MBO-niveau. Dit gebeurt door te kijken naar zowel de toekomstige arbeidsmarktperspectieven als de uitwijkmogelijkheden op de arbeidsmarkt. ${ }^{11}$ Daarnaast zullen de substitutiemogelijkheden voor werkgevers in verband gebracht worden met de verwachte knelpunten in de personeelsvoorziening. De substitutiemogelijkheden geven aan in hoeverre werkgevers voor een beroep arbeidskrachten kunnen aantrekken met uiteenlopende opleidingsachtergronden. Indien werkgevers afhankelijk zijn van het arbeidsaanbod van een bepaald opleidingstype zullen de substitutiemogelijkheden beperkt zijn.

\section{Uitwijkmogelijkheden voor schoolverlaters}

De mate waarin schoolverlaters en werkzoekenden afhankelijk zijn van de werkgelegenheidperspectieven van een bepaalde beroepsgroep vormt een risicoelement op de arbeidsmarkt. Dit risico is vooral groot bij opleidingen die specifiek gericht zijn op functies in één bepaalde vakdeelmarkt. Een voorbeeld van een zeer specialistische vakdeelmarkt is de arbeidsmarkt voor apothekersassistenten. Gediplomeerde apothekersassistenten zijn namelijk specifiek opgeleid en hun expertise is in vrijwel geen enkele andere beroepsgroep bruikbaar. Derhalve zal deze groep schoolverlaters, wanneer het werkgelegenheidsperspectief minder gunstig is, betrekkelijk moeilijk kunnen uitwijken naar beroepen waarvoor de werkgelegenheidsontwikkeling gunstiger is. Degenen die daarentegen een opleiding hebben gevolgd waarmee men in diverse beroepsgroepen aan de slag kan, kunnen gemakkelijker uitwijken naar beroepen waarvoor de werkgelegenheidsontwikkeling gunstiger is. In dit geval is er sprake van risicospreiding. Het volgen van een brede opleiding is overigens vanuit het oogpunt van de arbeidsmarkt gezien niet in alle gevallen als gunstig te beschouwen. Indien er sprake is van veel uitwijkmogelijkheden impliceert dit immers ook dat de schoolverlaters meer concurrentie ondervinden van andere opleidingstypen. Tevens kan een verbreding van de

11. In het kader van de betrouwbaarheid en de beschikbaarheid van de vereiste regionale data zijn de indicatoren voor de uitwijkmogelijkheden van schoolverlaters gebaseerd op landelijke cijfers. 
opleiding ten koste gaan van de specialisatie waardoor de productiviteit, c.q. de directe inzetbaarheid van de schoolverlaters, geringer wordt. Figuur 4.1 laat zien hoe groot in Overijssel de uitwijkmogelijkheden naar de verschillende beroepen zijn in combinatie met de toekomstige arbeidsmarkt-perspectieven voor schoolverlaters.

Het blijkt dat een aantal opleidingscategorieën zowel slechte arbeidsmarktperspectieven kunnen verwachten als te maken hebben met lage uitwijkmogelijkheden. Zij bevinden zich in het kwadrant linksonder in de figuur. Het betreft met name de opleidingssectoren VMBO Verzorging en MBO Dienstverlening en gezondheidszorg. Schoolverlaters met een dergelijke opleidingsachtergrond zullen geconfronteerd worden met relatief ongunstige arbeidsmarktperspectieven. Omdat het domein van opleidingen in deze richting vrij smal is, hebben schoolverlaters niet veel mogelijkheden om uit te wijken naar andere beroepsgroepen voor het vinden van een baan.

Figuur 4.1

De uitwijkmogelijkheden naar beroepsgroepen voor schoolverlaters in combinatie met de ITA voor Overijssel

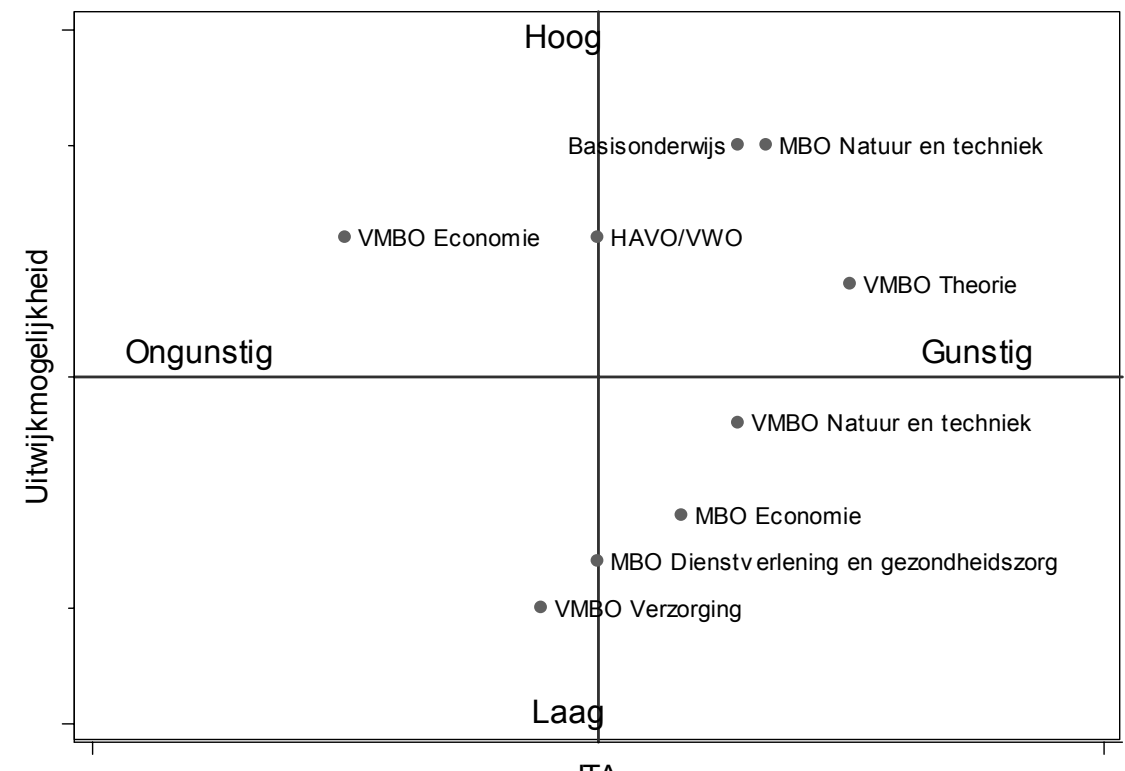

TA

\section{Substitutiemogelijkheden voor werkgevers}

De uitwijkmogelijkheden zullen hun weerslag hebben op de rekrutering van personeel voor verschillende beroepsgroepen. Wanneer voor een bepaald beroep kennis en vaardigheden vereist zijn die met name aanwezig zijn bij schoolverlaters met opleidingen waarvoor er tekorten zijn, zullen werkgevers problemen ondervinden bij het vinden van geschikt personeel. Indien tevens geldt dat voor dit beroep zeer beroepsspecifieke kennis en vaardigheden vereist zijn, zullen de knelpunten extra groot zijn. Men kan dan immers geen beroep doen op schoolverlaters met een 
opleiding die weliswaar niet direct aansluit op het beroep maar die met behulp van enige bijscholing de vereiste kennis en vaardigheden op kunnen doen. Als daarentegen een werkgever personeel nodig heeft voor beroepen waarvoor algemene competenties vereist zijn, kan de werkgever alternatieve opleidingen gebruiken om de knelpunten in de personeelsvoorziening op te lossen.

De aanwezigheid van substitutiemogelijkheden van personeel met verschillende opleidingsachtergrond kan dus van belang zijn afhankelijk van de verwachte knelpunten in de personeelsvoorziening, zoals deze gepresenteerd werden in paragraaf 4.3. De substitutiemogelijkheden geven aan in hoeverre werkgevers arbeidskrachten kunnen aantrekken met uiteenlopende opleidingsachtergronden. Indien werkgevers afhankelijk zijn van het arbeidsaanbod van maar één bepaald opleidingstype zullen de substitutiemogelijkheden beperkt zijn. De substitutiemogelijkheden voor de werkgevers kunnen bepaald worden aan de hand van een spreidingsindex van opleidingen over beroepsgroepen.

Figuur 4.2

De substitutiemogelijkheden voor werkgevers in combinatie met de ITKB voor Overijssel

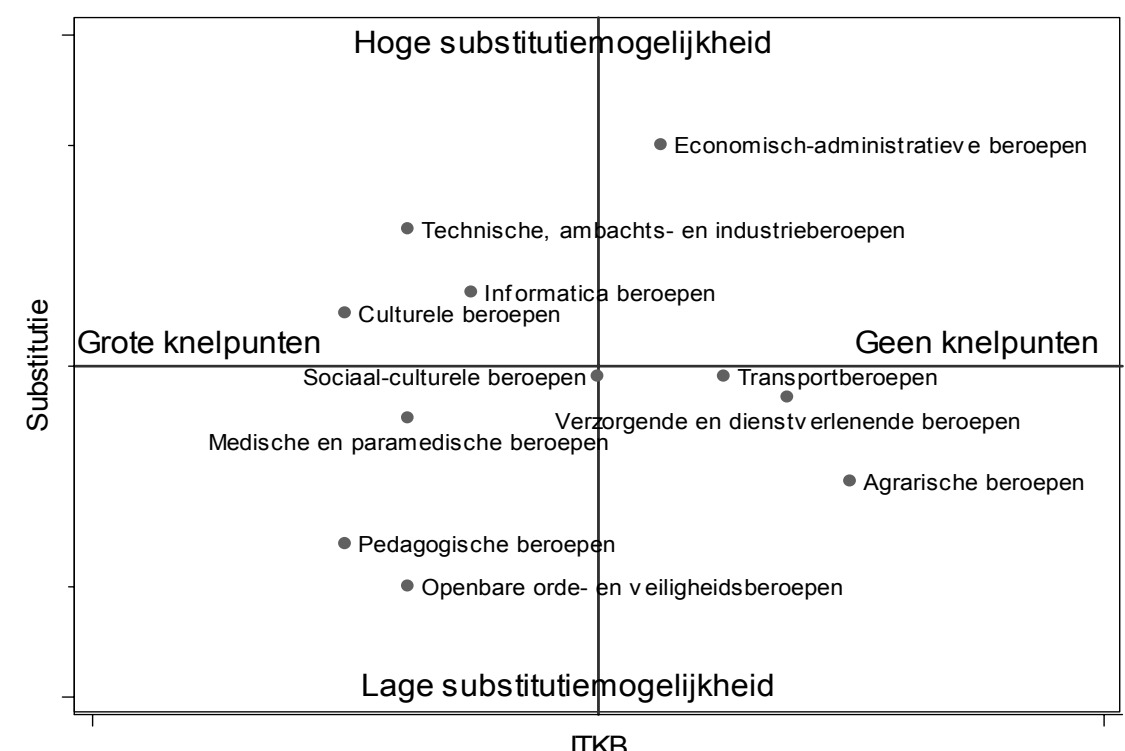

Figuur 4.2 laat zien dat er drie beroepsklassen zijn waarvoor de knelpunten in de personeelsvoorziening naar verwachting groot zullen zijn, terwijl de substitutiemogelijkheden gering zijn. Het betreft de Pedagogische beroepen, de Openbare orde en veiligheidsberoepen en de Medische en paramedische beroepen. Werkgevers die op zoek zijn naar personeel voor de openstaande vacatures zullen hier niet veel mogelijkheden hebben mensen aan te trekken uit andere beroepsklassen om de knelpunten te reduceren. Daarnaast blijken er vrijwel geen knelpunten in de personeelsvoorziening te worden verwacht bij de Agrarische beroepen, die wel lage substitutiemogelijkheden hebben. Voor de Technische en industrieberoepen daaren- 
tegen geldt dat er grote knelpunten verwacht worden, terwijl ook de substitutiemogelijkheden er groot zijn. Hetzelfde geldt voor Informatica beroepen en Culturele beroepen, zij het dat hier enigszins hogere substitutiemogelijkheden bestaan.

\subsection{Conclusie}

De arbeidsmarktvooruitzichten zijn goed voor schoolverlaters van de opleidingssectoren VMBO Theorie en MBO Natuur en techniek, en redelijk voor MBO Economie. Dit betekent voor werkgevers, dat werknemers uit deze opleidingssectoren op de middellange termijn moeilijker te vinden zijn. Voor de sector VMBO Economie en de sector verzorging op zowel VMBO als MBO niveau blijkt het aanbod van schoolverlaters op de middellange termijn de verwachte baanopeningen te overstijgen. Hierdoor zullen schoolverlaters met een dergelijke opleidingsachtergrond problemen ondervinden bij het vinden van een geschikte baan.

Werkgevers kunnen tot 2008 grote knelpunten in de personeelsvoorziening verwachten bij onder andere de Pedagogische beroepen door de zeer lage instroom van schoolverlaters. Bij deze beroepen zijn bovendien de substitutiemogelijkheden voor werkgevers beperkt. Bij de Culturele beroepen, de Technische en industrieberoepen, Medische en paramedische beroepen, de Informaticaberoepen en de Openbare orde en veiligheidsberoepen worden ook grote knelpunten in de personeelsvoorziening verwacht. Vrijwel geen knelpunten in de personeelsvoorziening worden verwacht bij de Agrarische beroepen en Verzorgende en dienstverlenende beroepen. De Transportberoepen evenals de Economisch-administratieve beroepen zullen geringe knelpunten vertonen. 


\section{De invloed van de conjunctuur op de prognose}

\subsection{Inleiding}

De arbeidsmarktprognose die in de hoofdstukken 3 en 4 is besproken is gebaseerd op de CPB prognose van de sectorale ontwikkeling voor Nederland. Deze prognose is door Etil vertaald naar Overijssel. Hierbij is rekening gehouden met de meest actuele cijfers op het moment van de prognose. Onverwachte ontwikkelingen kunnen immers tot een verandering in de inschatting van de eerder gemaakte prognose leiden. In dit hoofdstuk gaan wij in op de invloed van de - moeilijk voorspelbare conjuncturele ontwikkeling op de prognose. Hierbij gaat het met name om de mogelijke gevolgen voor de uitbreidingsvraag van bedrijven. De vervangingsvraag is namelijk minder conjunctuurgevoelig. Hier gaat het immers voornamelijk om de demografische ontwikkeling en de participatie op de arbeidsmarkt. De participatie wordt wel enigszins beïnvloed door de conjuncturele ontwikkeling, maar zal in dit hoofdstuk toch niet meegenomen worden. De invloed van de moeilijk voorspelbare conjuncturele ontwikkelingen op de prognose van de uitbreidingsvraag zal worden afgetast door een viertal groeiscenario's op te stellen van de sectorale werkgelegenheid. Voor elk scenario zullen vervolgens de gevolgen voor de uitbreidingsvraag naar beroepen en naar opleidingen worden nagegaan. De gevonden resultaten indiceren de bandbreedte voor de onzekerheden die verbonden zijn aan de officiële prognose van Etil.

\subsection{Sectorale trends}

Figuur 5.1

Lange termijn sectorale ontwikkeling van de werkgelegenheid in Nederland

Ontwikkeling sectorale werkgelegenheid in Nederland

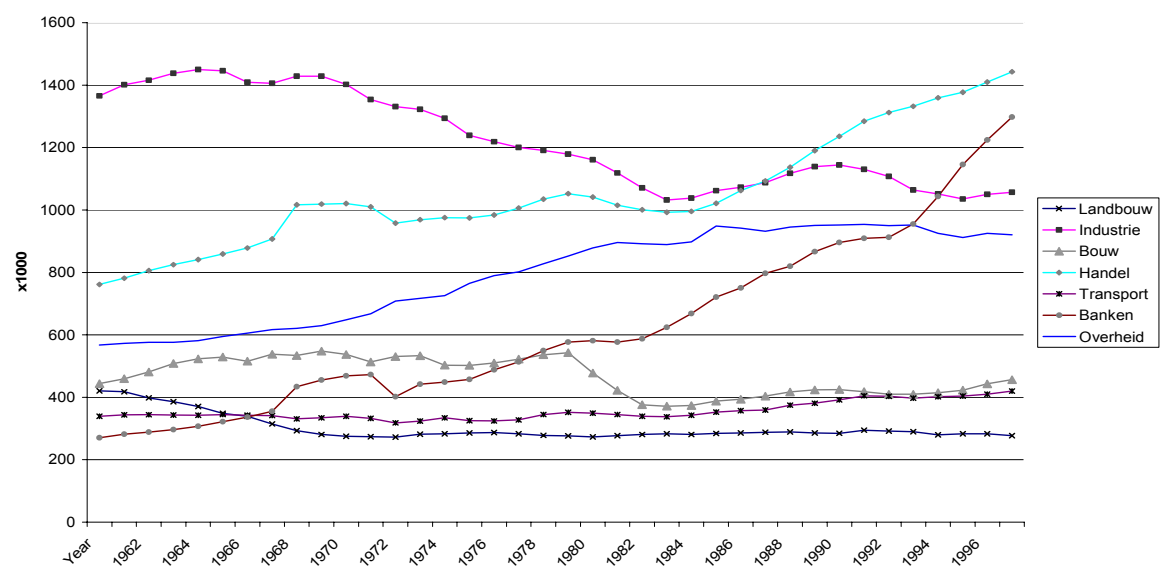

Bron: Groningen Long Data Series 
De sectorale werkgelegenheid in Nederland verandert over de jaren heen. Wij kunnen hier een onderscheid maken tussen structurele veranderingen en conjuncturele variaties.

\section{Figuur 5.2}

Ontwikkeling van de sectorale werkgelegenheid in Nederland en Overijssel op de middellange termijn

Sectorale Werkgelegenheid Nederland

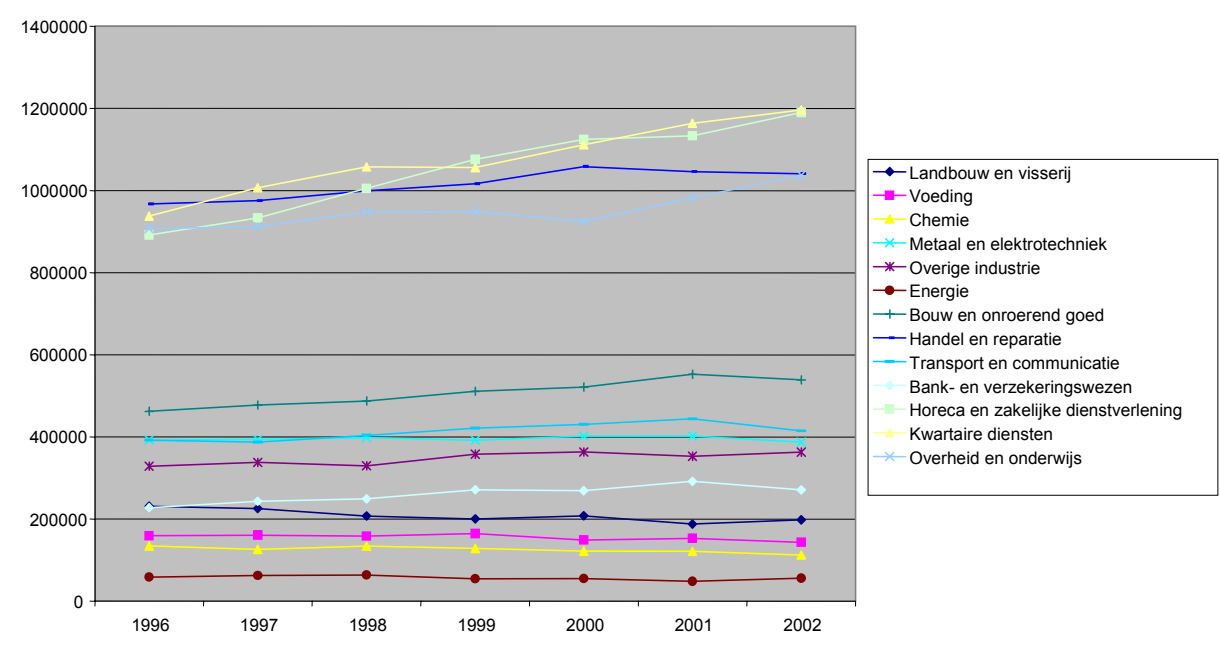

Sectorale Werkgelgenheid Overijssel

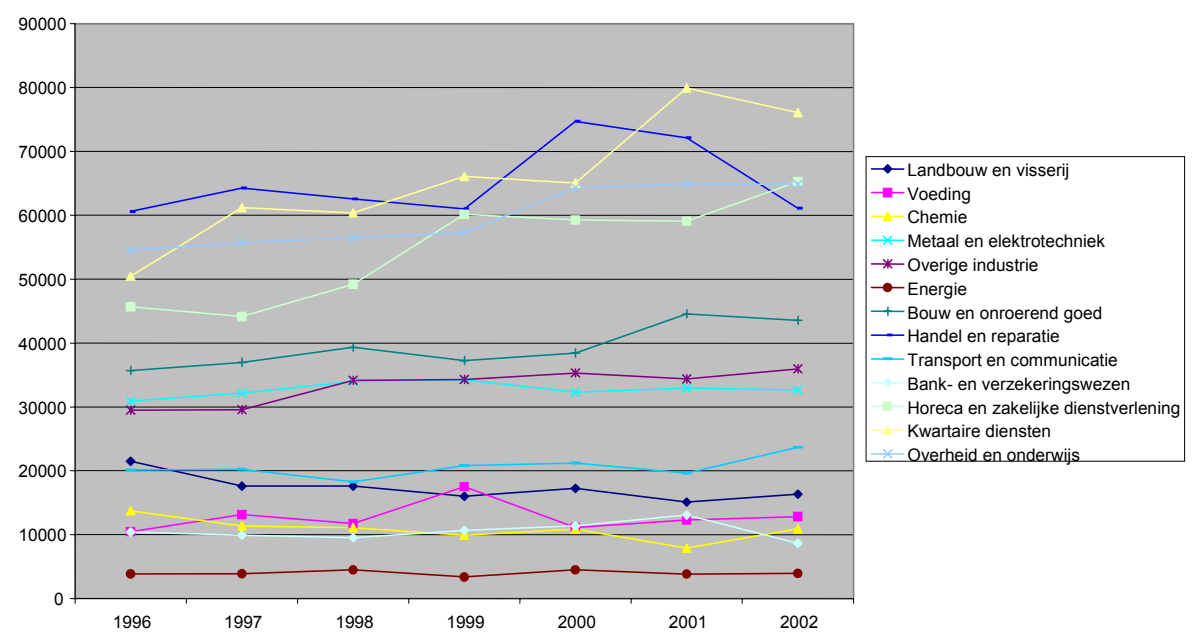

Bron: EBB (CBS), Etil 
De structurele veranderingen zijn alleen over de lange termijn te identificeren. Helaas zijn geen databronnen voor de lange termijn ontwikkeling van de sectorale werkgelegenheid in Overijssel beschikbaar. In de Nederlandse data vanaf 1960 zijn de algemene trends, die ook voor Overijssel zullen gelden, toch duidelijk te zien (zie figuur 5.1). De landbouw boet duidelijk in qua werkgelegenheid, vooral in de jaren zestig en zeventig. De werkgelegenheid in de industrie krimpt eveneens vanaf 1960 maar blijft sinds 1980 stabiel. De bouw verliest werkgelegenheid in de late jaren 70 en begin jaren 80 , om vervolgens op dat niveau te stabiliseren. De groei van de werkgelegenheid zit vooral in de dienstensectoren: financiële diensten, overheid, en ook tot op zekere hoogte, transport. Dit zijn de lange termijn trends die in Nederland speelden, maar die ook typisch zijn voor ontwikkelde economieën in de westelijke wereld. Deze lange termijn ontwikkeling heeft ook invloed op de prognose, zoals deze is weergegeven in de hoofdstukken 3 en 4 . Ook met betrekking tot de beroepenstructuur van sectoren treden veranderingen op van structurele aard. Het gebruikte prognosemodel houdt rekening met deze structurele veranderingen in zowel de sector als ook de beroepen (en opleidingen). Conjuncturele invloeden daarentegen worden in eerste instantie zoveel mogelijk buiten het model gehouden. Zij komen slechts indirect, via de gemaakte sectorprognose - dus de verwachte ontwikkeling van de sectorale werkgelegenheid - terug in de prognose voor de vraag naar beroepen en opleidingen.

\subsection{Sectorale ontwikkeling van de beroepsbevolking in Overijssel}

De sectorale ontwikkeling van de beroepsbevolking van 1996-2002 wordt geschetst in figuur 5.2. Hier kunnen ook enkele trends waargenomen worden. Er moet echter rekening worden gehouden met de aanwezigheid van conjuncturele invloeden. Voor de groei van de werkgelegenheid is met name de economische groei (groei van de toegevoegde waarde) belangrijk. Figuur 5.3 schetst de economische groei van Overijssel in vergelijking met de economische groei voor heel Nederland. Van 19961999 loopt Overijssel achter op de Nederlandse groei, om in 2000 aan het einde van een periode van economische groei te versnellen en een iets hogere groei te realiseren dan Nederland. In dit jaar bereikt Overijssel ook de hoogste groei voor de periode van 1996-2003. In de daaropvolgende jaren 2001-2003 doet Overijssel het weer slechter dan Nederland. De groei zakt in en er is zelfs sprake van werkgelegenheidskrimp volgens de (voorlopige) cijfers van de regionaal economische statistieken van het CBS.

Wat betekent economische groei in Overijssel voor de sectorale werkgelegenheid? Om dit goed voor ogen te krijgen gebruiken wij een figuur waarin de economische groei en de procentuele verandering van de sectorale werkgelegenheid naast elkaar weergegeven worden (figuur 5.4). Over deze korte periode is het moeilijk om structurele trends en conjuncturele variaties uit elkaar te halen. De structurele daling van de werkgelegenheid in de sector Landbouw is weliswaar terug te vinden in de grafiek, maar of de relatieve veranderingen het gevolg zijn van de conjunctuurcyclus is niet gemakkelijk af te leiden. Wel kunnen wij vaststellen dat sommige sectoren redelijk onafhankelijk van de economische groei blijken te zijn. De sectoren Kwartaire 
Figuur 5.3

Economische groei in Nederland en Overijssel 1996-2003, percentages

Economische Groei

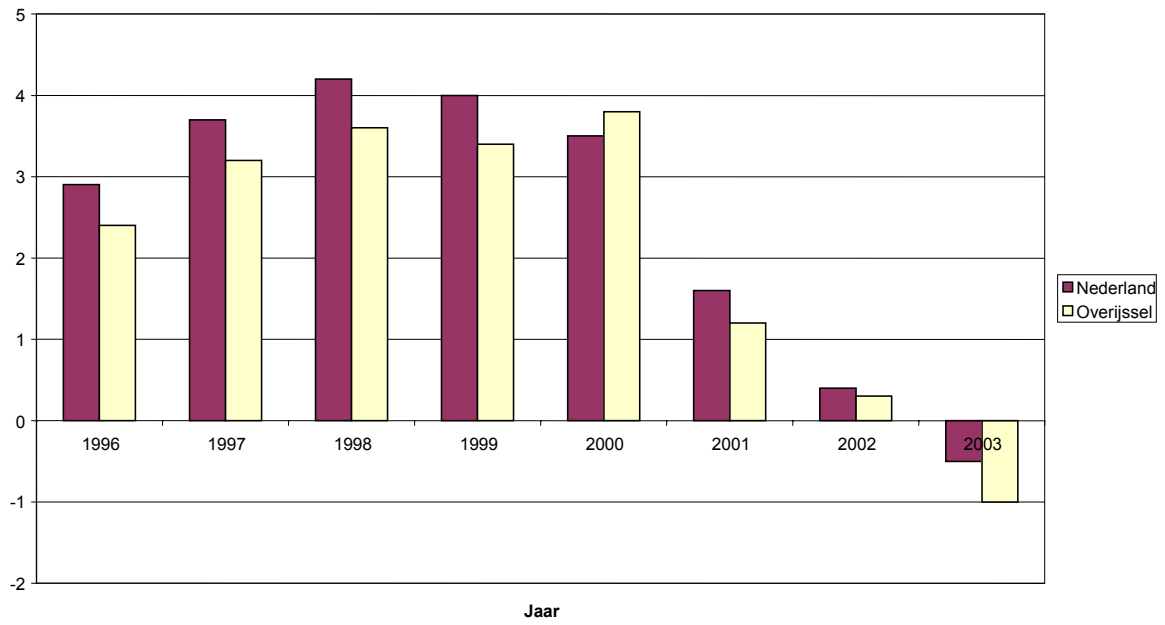

Bron: CBS Regionale Statistieken

Figuur 5.4

Economische groei en sectorale werkgelegenheidsgroei in Overijssel 1996-2003, percentages

Overijssel groei en werkgelegenheidsverandering

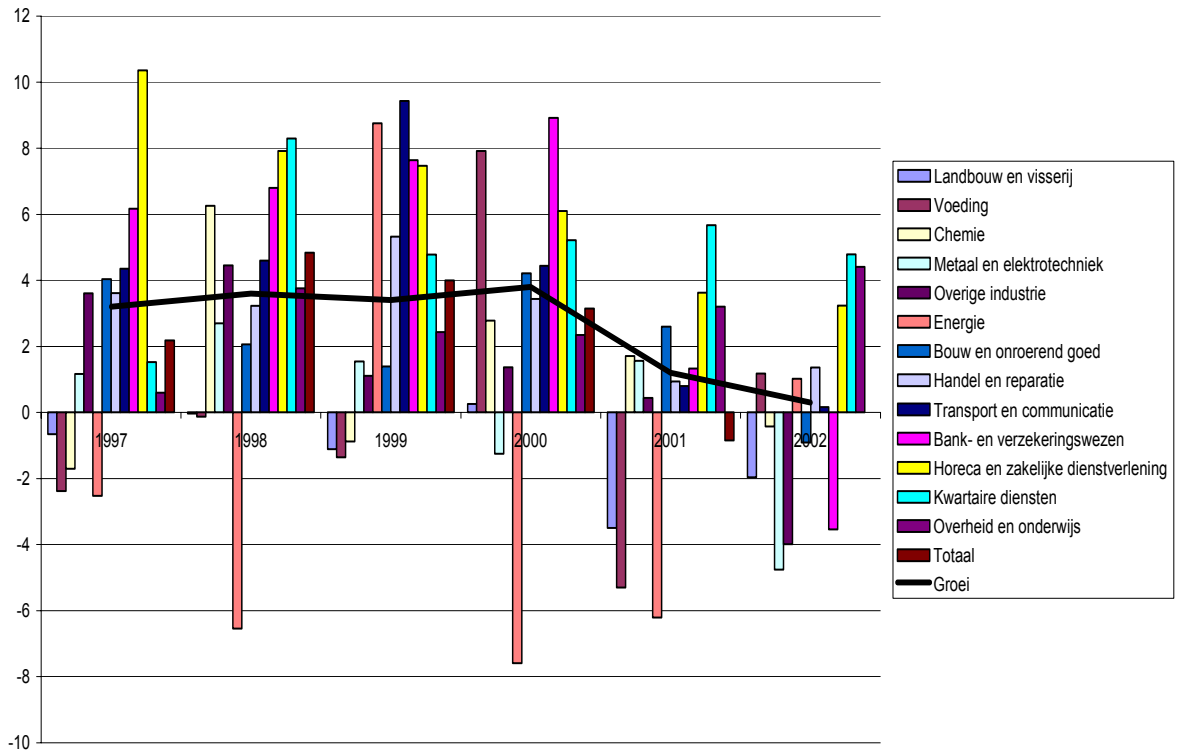

Bron: CBS Regionale Statistieken 
diensten en Overheid en onderwijs lijken niet bijzonder beïnvloed door de conjunctuur. Maar Horeca en zakelijke dienstverlening groeit duidelijk minder in periodes van lage economische groei. Er is dus een positief verband tussen economische groei en groei van de werkgelegenheid in sectoren, maar wanneer een sector precies de conjuncturele ontwikkeling volgt is onduidelijk. Dit hangt mede samen met de aanpassingskosten van personeel, hoe lang bedrijven werknemers in dienst houden bij tegenvallende opdrachten en de verwachtingen die ondernemers hebben.

\subsection{Vier Scenario's}

De vier scenario's van de uitbreidingsvraag naar arbeid die wij hier presenteren schetsen een situatie waarin de groei van de werkgelegenheid afwijkt van de officiële prognose van het Etil. De gekozen scenario's geven situaties weer die ten opzichte van de originele prognose te betitelen zijn als 'zeer pessimistisch' (scenario 1), 'pessimistisch' (scenario 2), een 'gematigd middenscenario' (scenario 3) en 'zeer optimistisch' (scenario 4) (zie tabel 5.1). De zeer pessimistische prognose gaat uit van een langdurige krimp van de werkgelegenheid, waardoor slechts in enkele sectoren baangroei te verwachten is. Dit komt overeen met een langdurige recessie. Het pessimistische scenario (scenario 2) schetst een gematigde tot slechte economische situatie. Enkele sectoren vertonen hier een krimpende werkgelegenheid, terwijl andere sectoren matig groeien. Dit scenario weerspiegelt een situatie van een aanhoudende lichte tot afwezige economische groei: een kwakkelende economie. De matige groei van scenario 3 geeft een licht optimistischer beeld weer dan de prognose die in de hoofdstukken 3 en 4 is gebruikt. Scenario 4 ten slotte moet gezien worden als een exercitie van wat in een periode van bijzonder hoge werkgelegenheidsgroei zal gebeuren. In de volgende tabellen zijn prognoses en scenario's aangegeven met een donkerder getinte ondergrond naarmate zij aannemelijker zijn. Uiteraard houden wij de prognose het meest aannemelijk terwijl de twee scenario's met licht hogere of lagere groei iets minder aannemelijk geacht worden. De twee scenario's met bijzonder lage of bijzonder hoge werkgelegenheidsgroei zijn niet grijs ingekleurd: wij achten deze het minst aannemelijk en ze moeten gezien worden als een analyse wat onder zulke - extreme - omstandigheden zou gebeuren.

In de scenario's is duidelijk te zien dat de uitbreidingsvraag conjunctuurafhankelijk is. Slechts in het zeer optimistische groeiscenario 4 is een positieve uitbreidingsvraag van alle beroepsgroepen te zien. Zelfs de Agrarische beroepen vertonen hier een lichte groei. Het licht positieve Scenario 3 laat een positieve uitbreidingsvraag zien voor alle beroepsgroepen met uitzondering van de Agrarische beroepen. De groei pakt dus positief uit voor alle beroepsgroepen of zij direct conjunctuurafhankelijk zijn of niet. Het tegenovergestelde beeld, namelijk een langere periode van krimp, is het duidelijkst in scenario 1 te zien. Interessant is dat enkele beroepsgroepen zich aan de economische malaise kunnen onttrekken. Dit zijn de Pedagogische beroepen, de Culturele beroepen, de (Para-)medische beroepen, de Informatica beroepen en in mindere mate de Verzorgende en dienstverlenende beroepen. Deze beroepsgroepen blijken uit de scenario-analyse ook bij tegenvallende economische groei nog 
uitbreidingsvraag te vertonen, en duidelijk, althans qua groeirichting, conjunctuuronafhankelijk te zijn.

Tabel 5.1

Vier Scenario's, 2003-2008, percentages

\begin{tabular}{lcc}
\hline & 5-jaars groei & jaarlijkse groei \\
\hline Scenario 1: extreem lage werkgelegenheidsgroei & -5 & -1.0 \\
Scenario 2: lage werkgelegenheidsgroei & 3 & 0.5 \\
Prognose & 4 & 0.8 \\
Scenario 3: matige werkgelegenheidsgroei & 8 & 1.5 \\
scenario 4: hoge werkgelegenheidsgroei & 13 & 2.5 \\
\hline Bron: ROA & &
\end{tabular}

Tabel 5.2

Uitbreidingsvraag beroepen volgens de Scenario's, 2003-2008, percentages

\begin{tabular}{|c|c|c|c|c|c|c|}
\hline & $\begin{array}{c}\text { Scenario } \\
1\end{array}$ & $\begin{array}{c}\text { Scenario } \\
2\end{array}$ & Prognose & $\begin{array}{c}\text { Scenario } \\
3\end{array}$ & $\begin{array}{c}\text { Scenario } \\
4\end{array}$ & Variatie \\
\hline $\begin{array}{l}\text { Pedagogische } \\
\text { beroepen }\end{array}$ & 1 & 8 & 10 & 13 & 18 & 17 \\
\hline $\begin{array}{l}\text { Culturele beroepen } \\
\text { Agrarische }\end{array}$ & 7 & 17 & 19 & 24 & 31 & 24 \\
\hline $\begin{array}{l}\text { beroepen } \\
\text { Technische, } \\
\text { ambachts- en } \\
\text { industrieberoepen }\end{array}$ & -14 & -2 & -1 & -4 & 8 & 17 \\
\hline $\begin{array}{l}\text { Transportberoepen } \\
\text { Medische en } \\
\text { paramedische }\end{array}$ & -5 & 2 & 3 & 7 & 12 & 17 \\
\hline $\begin{array}{l}\text { beroepen } \\
\text { Economisch- } \\
\text { administratieve }\end{array}$ & 1 & 9 & 11 & 15 & 21 & 20 \\
\hline $\begin{array}{l}\text { beroepen } \\
\text { Informatica }\end{array}$ & -6 & 2 & 3 & 7 & 13 & 19 \\
\hline $\begin{array}{l}\text { beroepen } \\
\text { Sociaal-culturele }\end{array}$ & 7 & 19 & 22 & 28 & 37 & 30 \\
\hline $\begin{array}{l}\text { beroepen } \\
\text { Verzorgende en } \\
\text { dienstverlenende }\end{array}$ & -8 & 0 & 2 & 5 & 11 & 19 \\
\hline $\begin{array}{l}\text { beroepen } \\
\text { Openbare orde- en }\end{array}$ & 0 & 7 & 9 & 12 & 17 & 17 \\
\hline veiligheidsberoepen & -2 & 4 & 5 & 8 & 13 & 15 \\
\hline Totaal & -5 & 3 & 4 & 8 & 13 & 18 \\
\hline
\end{tabular}

Bron: ROA 
De stabiele onderlinge verhouding tussen de beroepen is niet verassend omdat de conjuncturele ontwikkeling via de werkgelegenheidgroei van sectoren aan het bestaande model opgelegd is. Er is dus geen rekening gehouden met de wisselwerking tussen vraag en aanbod. Ook is het interessant om naar de absolute verandering te kijken van scenario 1 naar scenario 4, dus van het meest pessimistische naar het meest optimistische scenario (zie laatste kolom 'Variatie' in tabel 5.2).

Grote veranderingen zijn te zien bij de Informaticaberoepen, de Culturele beroepen en enigermate bij de Medische en paramedische beroepen. De laagste volatiliteit is bij de Openbare orde- en veiligheidsberoepen en de Agrarische beroepen. Toch is het belangrijk om een onderscheid te maken tussen beroepen die een hoge variabiliteit over de scenario's hebben terwijl zij altijd groei blijven vertonen (bijvoorbeeld Informaticaberoepen) en beroepen die van krimp overgaan op groei (bijvoorbeeld Agrarische beroepen). Bij de laatste categorie is het duidelijk afhankelijker van de conjuncturele situatie om daar werk te vinden. Aan de andere kant is het bij beroepen die extreme variabiliteit in groei vertonen voor werkgevers een probleem omdat voor deze beroepen in tijden van sterke economische groei moeilijker voldoende werknemers te vinden zijn.

Ook bij de opleidingen zijn duidelijke verschillen in conjuncturele afhankelijkheid vast te stellen (zie tabel 5.3). Lager opgeleide werknemers lijken meer last te hebben van conjunctuurgevoeligheid. Opvallend is dat twee opleidingen - Basisonderwijs en VMBO Natuur en techniek - ook bij sterk positieve groei een negatieve uitbreidingsvraag vertonen. Dit blijkt het gevolg te zijn van veranderingen van de werkgelegenheidsstructuur van sectoren en beroepen waarin veel mensen met deze opleidingsachtergrond werken. Interessant is dat de beroepen en opleidingen die minder conjunctuurgevoelig zijn redelijk met elkaar overeenkomen. De medische en verzorgende opleidingen lijken bijvoorbeeld minder conjunctuurgevoelig te zijn.

Als wij wederoom naar de variatie over de scenario's kijken dan is de grootste variatie bij HAVO/VWO, WO Economie, en WO Letteren en sociaal-cultureel te vinden. Maar dit zijn wederom categorieën die in alle scenario's een positieve uitbreidingsvraag vertonen. Opvallend is dat WO Medisch een redelijk lage variatie vertoont, zodat de gevonden hoge werkgelegenheidsvariatie van de medische en verzorgende beroepen vooral in de lagere en middelbaar opgeleide beroepen zal zitten.

\subsection{Conclusie}

Uit de scenario-analyse blijkt dat de lagere beroepen en vooral ook de middelbare beroepen door tegenvallende groei kunnen worden getroffen. Terwijl zij flink zullen groeien in een voorspoedige economische omgeving, krimpen zij ook net zo hard in bij tegenvallende economische groei. De vervulling van beroepen gaat bij tegenvallende groei ten koste van de laagst opgeleiden. Hoe slechter de economische situatie hoe groter de krimp onder werknemers met 'Basisonderwijs' of 'VMBO'. 


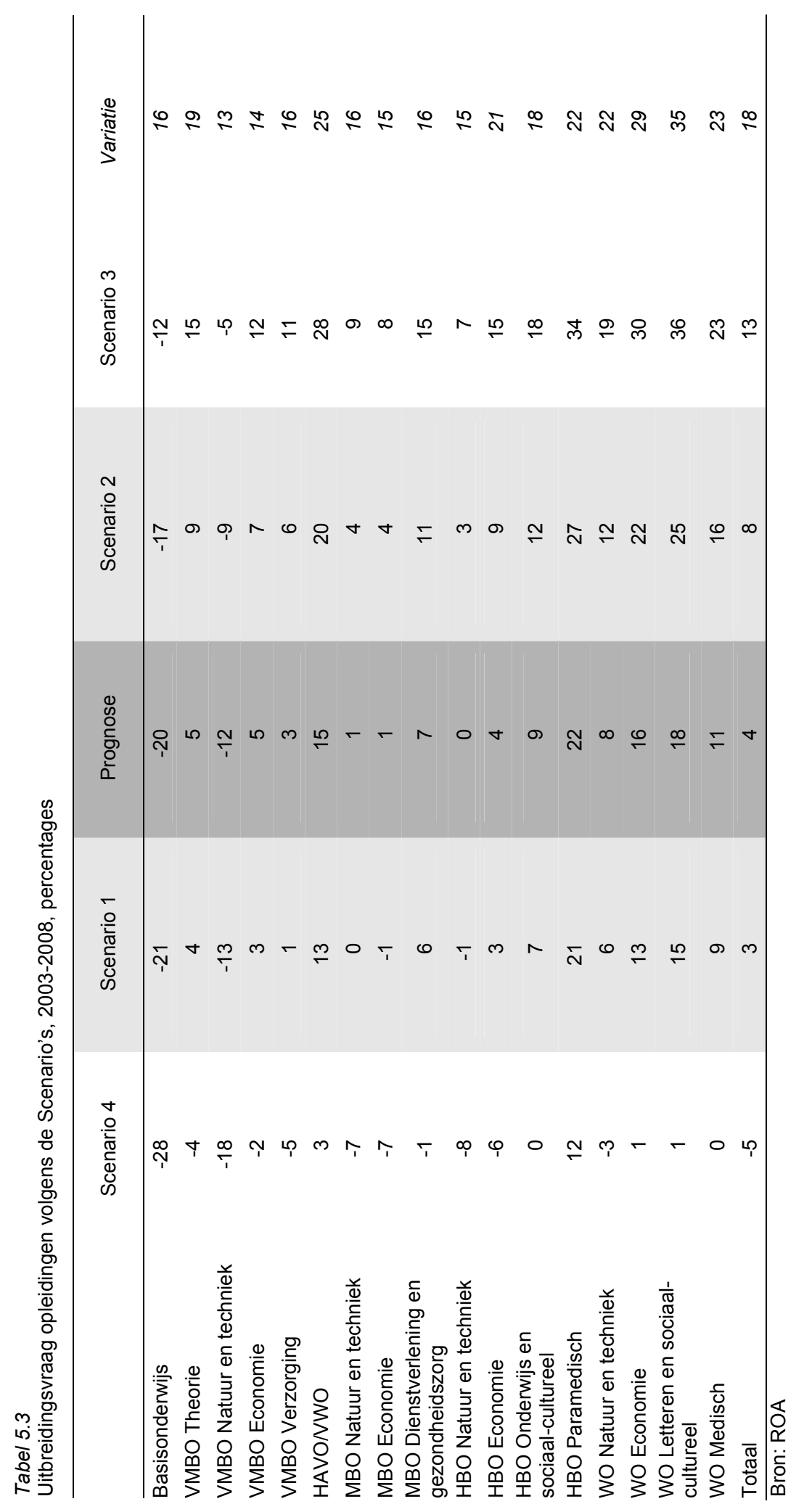


Hieruit valt te concluderen dat werkgevers proberen om vooral hoger en middelbaar opgeleide werknemers in dienst te houden, ook al zitten zij op functies die ook door lager opgeleiden vervuld kunnen worden.

Aan de andere kant van het spectrum kunnen bij positieve economische omstandigheden vooral bij hoger opgeleiden personele knelpunten ontstaan voor werkgevers. Hierdoor zal ruimte ontstaan voor het aantrekken van iets lager opgeleiden, zodat via een 'schoorsteeneffect' alle opleidingsniveaus van het gunstige economische tij profiteren. Door werkgevers zou in een dergelijke situatie van goede economische vooruitzichten vroegtijdig gereageerd moeten worden om het benodigde personeel te kunnen aantrekken. 



\section{De onderkant van de arbeidsmarkt}

\subsection{Inleiding}

De aantrekkelijkheid van een baan hangt van een aantal factoren af. Van belang zijn bij voorbeeld de inhoud en het niveau van de baan en hoe deze aansluiten bij de gevolgde opleiding. Daarnaast zijn de arbeidsvoorwaarden van belang, zoals het salaris en de baanzekerheid. Ook de doorgroeimogelijkheden en de arbeidsomstandigheden vormen factoren die de aantrekkelijkheid van een baan bepalen. Een slechte arbeidsmarktpositie valt dan te typeren door een weinig aantrekkelijke inhoud en niveau van werkzaamheden die slecht bij de gevolgde opleiding aansluiten, ongunstige arbeidsvoorwaarden, beperkte doorgroeimogelijkheden en arbeidsomstandigheden die te wensen overlaten. Aan de 'onderkant van de arbeidsmarkt', waar zich de banen bevinden voor ongeschoolden en laagopgeleiden, is vaak sprake van een cumulatie van de genoemde ongunstige factoren.. Een belangrijke aanwijzing voor de slechte arbeidsmarktpositie van ongeschoolden en laagopgeleiden is hun lage arbeidsparticipatie. Over het algemeen neemt de participatie toe naarmate het opleidingsniveau hoger is. Van de ongeschoolden is bijna $50 \%$ niet beschikbaar voor de arbeidsmarkt, tegenover nog geen $10 \%$ van de universitair opgeleiden. Dit wijst erop dat velen die ongeschoold of laagopgeleid zijn vroeg of laat de arbeidsmarkt de rug toekeren.

In dit hoofdstuk zullen wij ons bezighouden met de economische achtergronden voor de geschetste problemen aan de onderkant van arbeidsmarkt. Deze problemen betreffen vooral laag opgeleiden die ouder zijn en geen langdurige arbeidsverhouding hebben, of jong zijn en hun school niet hebben afgemaakt. Met name de laatste groep, de jongeren, zijn beleidsmatig van belang omdat zij nog een heel arbeidsleven voor de boeg hebben. Vroegtijdig ingrijpen kan hier wellicht veel leed besparen. Problemen aan de onderkant houden vaak verband met de aanwezigheid van bepaalde instituties. Het aannemen van personeel is bijvoorbeeld duur in verband met de te maken kosten voor werving en selectie en voor het opvangen van het afbreukrisico van een verkeerde keuze. Ook kunnen minimumlonen werknemers te duur maken voor bepaalde werkzaamheden. Het gebrek aan competenties die voor een goed functioneren nodig zijn en een te lage productiviteit zijn de andere kant van het verhaal. Hier speelt bovendien dat competenties en productiviteit door leereffecten verbeteren waardoor werkloze jongeren zonder ervaring die de benodigde competenties en ervaring niet kunnen opbouwen, minder kansen hebben op een baan. Sterker nog, een deel van de aanwezige kennis en vaardigheden kan verloren gaan, waardoor zij nog onaantrekkelijker worden voor de arbeidsmarkt. Hier dreigt dus een vicieuze cirkel die vroegtijdig doorbroken moet worden.

In paragraaf 6.2 zullen wij de onderkant van de arbeidsmarkt afbakenen. In paragraaf 6.3 geven wij een economische analyse van het probleem van de onderkant van de arbeidsmarkt. In paragraaf 6.4 wordt een vergelijking gemaakt van de situatie aan de 
onderkant tussen Nederland en Overijssel. Door deze vergelijking te maken kunnen mogelijke probleemgroepen geïdentificeerd worden en kan een inschatting gemaakt worden van de grootte van het probleem. Dit is ook het doel van paragraaf 6.5 waar wordt teruggekeken op de in hoofdstuk 5 gemaakte conjunctuur scenario's. Deze scenario's worden nu vooral belicht vanuit het de implicaties die zij hebben voor de onderkant van de arbeidsmarkt. In paragraaf 6.6 worden de conclusies van het hoofdstuk samengevat en worden enkele mogelijke beleidsopties aangegeven,

\subsection{Afbakening van de onderkant}

Voor de afbakening van de onderkant van de arbeidsmarkt moet een keuze voor een bepaald criterium worden gemaakt. Men kan deze afbakening op basis van het inkomen maken en derhalve iedereen van de beroepsbevolking tot de onderkant van de arbeidsmarkt rekenen die laag in de (nationale) inkomensverdeling zit. Een andere mogelijkheid is om mensen die herhaaldelijk werkloos worden tot de onderkant te rekenen. In het vervolg zullen wij de 'onderkant van de arbeidsmarkt' definiëren aan de hand van de hoogst behaalde opleiding omdat het opleidingsniveau samenhangt met een veelheid van andere factoren die relevant zijn voor de arbeidsmarktpositie. Personen die geen afgesloten VMBO- of vergelijkbare opleiding hebben, zullen - als ongeschoolden - tot de 'onderkant' gerekend worden. Maar ook werkenden met een VMBO-opleiding kampen vaak met de typische problemen van de 'onderkant': baanonzekerheid, tijdelijke contracten en opeenvolgende werkloosheid. Daarom zullen de analyses in dit hoofdstuk meestal worden uitgevoerd aan de hand van een indeling in vijf opleidingsniveaus: Basisonderwijs, VMBO (incl. theorie), MBO/HAVO/VWO, HBO, en WO.

\subsection{Het economische probleem}

In deze paragraaf zal een aantal theoretische noties worden gegeven met betrekking tot de onderkant van de arbeidsmarkt. Hierbij wordt een economische invalshoek gevolgd waarbij het met name zal gaan om de productiviteit en het loon van ongeschoolden en laagopgeleiden gedurende hun levensloop. Er zal worden ingegaan op de implicaties van de theorie van de duale arbeidsmarkt voor ongeschoolden en laagopgeleiden.

De traditionele economische theorie gaat ervan uit dat werknemers naar hun productiviteit betaald worden. Dit is gebaseerd op een veronderstelde wereld waar geen informatieproblemen zijn. Werknemers worden geacht mobiel en flexibel genoeg te zijn om elke baan aan te kunnen nemen. Ook lonen zijn flexibel en kunnen aan de productiviteit aangepast worden. Werknemers kunnen zonder kosten in dienst genomen worden, en ook net zo makkelijk weer ontslagen. Dit geeft vanzelfsprekend niet de actuele situatie voor de laag opgeleide werknemer weer. De arbeidsmarkten kenmerken zich door fricties. Institutionele belemmeringen zorgen ervoor dat arbeidsmarkten geen volledige markten zijn. Zo zorgt bijvoorbeeld het 
minimum(jeugd)loon ervoor dat werknemers met een productiviteit die lager is dan het minimumloon niet aantrekkelijk zijn voor werkgevers.

Een institutionele factor die invloed heeft op het functioneren van de arbeidsmarkt is de wettelijke bescherming van werknemers bij ontslag. Het ontslaan van een werknemer brengt een 'opzegtermijn' en bepaalde kosten voor de werkgever met zich mee. Anticiperend op deze kosten die bij een tegenvallende productie moeten worden gemaakt, is een werkgever daarom minder gauw geneigd om werknemers in dienst te nemen dan in het geval werknemers minder beschermd zijn. Deze aanpassingskosten bij ontslag komen nog bovenop de kosten die gemaakt moeten worden bij het in dienst nemen van nieuwe krachten. Ook hier zijn vaak hoge kosten aan verbonden. Dit is ook de verklaring waarom in tijden van aantrekkende vraag in eerste instantie met overwerk en met tijdelijke uitzendkrachten gewerkt wordt, ook al zijn de directe kosten hiervan hoger. Kennelijk wegen de hogere flexibiliteit ondanks de hieraan verbonden hoge aanpassingskosten op tegen het risico om een nieuwe werknemer in dienst te nemen.

Werknemers hebben in hun baan te maken met een inwerktijd en met leereffecten. De productiviteit van de werknemer stijgt met zijn ervaring. In economische termen gezien, bouwt hij ook na het onderwijs verlaten te hebben menselijk kapitaal op door bij de werkgever ervaring op te doen en verdere scholing te volgen. Hoe hoger het menselijk kapitaal hoe hoger de productiviteit. Het is belangrijk onderscheid te maken tussen algemeen menselijk kapitaal en specifiek menselijk kapitaal. Het algemeen menselijk kapitaal is bij verschillende werkgevers in verschillende bedrijfssectoren te gebruiken terwijl specifiek menselijk kapitaal slechts nuttig is bij de huidige werkgever, in de huidige functie of wellicht in de huidige bedrijfssector. Hierdoor is de initiële productiviteit laag, immers alleen het dan bij de nieuwe werknemer aanwezige algemeen kapitaal wordt beloond. In figuur 6.1 wordt een hypothetisch geval weergegeven van een werknemer die op zijn 18e begint te werken en vervolgens bij zijn werkgever verder bouwt aan zijn menselijk kapitaal. De stijgende lijn in de figuur geeft het verloop van zijn productiviteit weer. Problematisch is echter indien de werknemer naar een andere baan of werkgever zou willen overstappen waar de door hem bij zijn werkgever opgebouwde kennis niet van belang is. Hierdoor zou zijn productiviteit omlaag vallen. Indien een aanpassing van het salaris niet mogelijk of acceptabel is, zal een dergelijke werknemer geen nieuwe baan vinden.

Een ander probleem is dat menselijk kapitaal, met name kennis, veelal veroudert. Door onvoldoende benutting van zijn vaardigheden verleert men hoe bepaalde handelingen verricht moeten worden. Of bepaalde beroepen vergen juist een continue aanpassing aan nieuwe technieken die men eerst moet leren onder de knie te krijgen. Werkloosheid of inactiviteit van mensen kan daarom tot een dramatische daling van de marktwaarde van hun kennis leiden. Zij worden door niet te werken minder productief en daarom onaantrekkelijk voor potentiële werkgevers. Het is moeilijk om deze vicieuze cirkel te doorbreken. 
Figuur 6.1

Productiviteit en menselijk kapitaal naar leeftijd

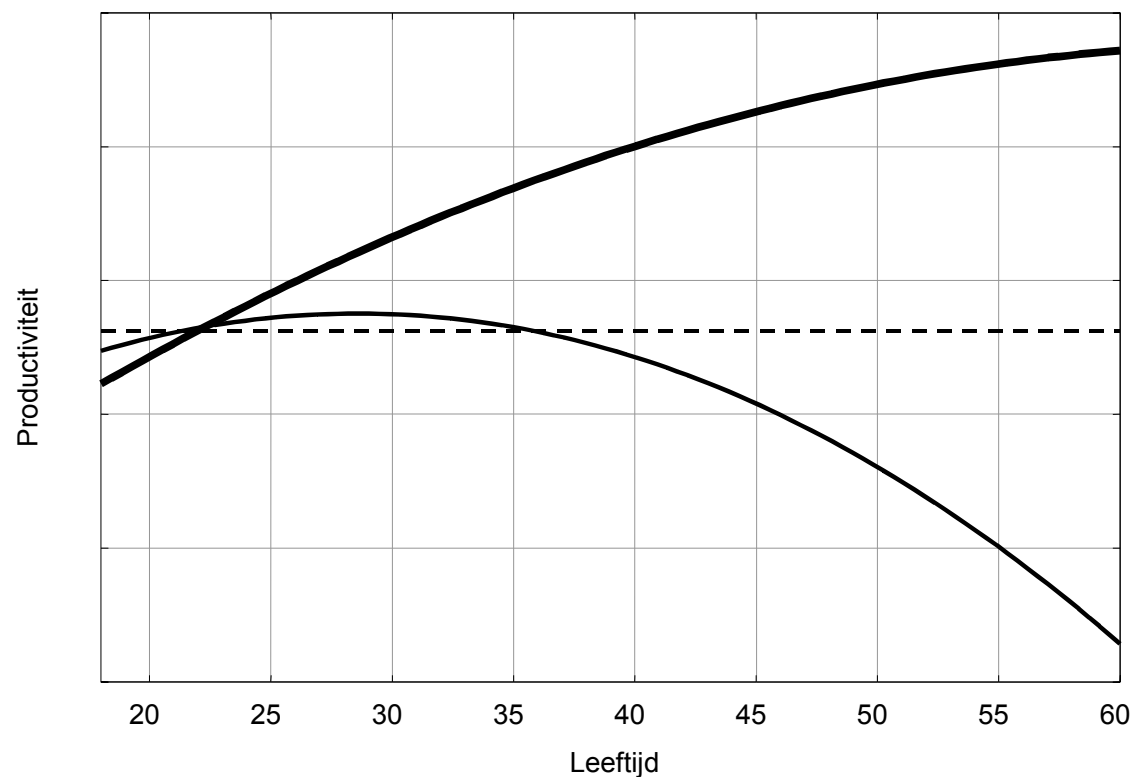

In veel Nederlandse bedrijven en CAO's zijn ook zogenoemde 'age-tenure-profiles' afgesproken. Dit betekent dat jongere werknemers lager ingeschaald en beloond worden dan oudere werknemers. Oudere mensen, zo is de redenering, hebben meer ervaring en verdienen daarom een hoger loon. Economisch gezien zou een stijgend 'age-tenure-profile' slechts nuttig zijn indien dit de met de leeftijd stijgende productiviteit weerspiegeld. Dus als oudere mensen door hun grotere ervaring ook beter functioneren. Verder zou zulk een aan leeftijd gebonden loonprofiel ook voor carrières binnen bedrijven nuttig zijn als men werknemers aan zich wil binden. In dat geval wordt de werknemer initieel onderbetaald, om later meer dan zijn productiviteit betaald te krijgen. ${ }^{12}$ Dit is dan een impliciete afspraak tussen bedrijf en werknemer, maar het is moeilijk een economisch reden te vinden om het bestaan van een dergelijke afspraak over de hele economie vol te kunnen houden.

Voor de onderkant van de arbeidsmarkt betekent dit dat oudere werknemers die onvoldoende kennis of ervaring hebben geen baan aangeboden krijgen. Zij Zijn relatief te duur voor een werkgever, die liever een jonge kracht wil hebben die nog kan worden ingeschaald aan het begin van het loongebouw. Dit wordt nog verergerd als functies een langere (interne) opleiding of inwerktijd vergen. Deze opleiding leidt wel tot hogere productiviteit in de functie, maar de kosten ervan moeten normaal gesproken over het arbeidsleven terugverdient worden. Als de verwachte duur van

12. Dit is uitgewerkt in een inmiddels klassiek economisch artikel: E. Lazear (1979), The Journal of Political Economy. 
de resterende terugverdientijd kort is, zal een werkgever niet graag in een oudere werknemer investeren.

Aan andere kant staat het probleem van de jeugdwerkloosheid. Hier spelen andere factoren een rol. Ten eerste is jeugdwerkloosheid vooral een probleem onder laag opgeleide jongeren. Als zij nog geen werk ervaring hebben, zou hun (minimum-)loon hoger kunnen zijn dan de productiviteit die zij voor een bedrijf opleveren. Slechts nadat zij enkele jaren gewerkt hebben, zou dit probleem verholpen zijn. Dit is een reden om in beginsel een jeugdminimumloon in te voeren dat lager is dan voor werknemers die ouder zijn. Hier komt nog vaak bij dat de werkgever onzeker is over de betrouwbaarheid van de (jonge) werknemer. Hoe lang zal deze in het bedrijf blijven? Is het de moeite waard om in hem of haar te investeren? Pas als iemand ook met weinig opleiding - een langer arbeidsverleden heeft, lijkt hij of zij betrouwbaar te zijn. Deze vicieuze cirkel moet doorbroken worden. Jongeren moeten in staat zijn om zichzelf te bewijzen en door enkele jaren te werken hun betrouwbaarheid aan te tonen en de werkervaring op te bouwen die hun waarde op de arbeidsmarkt vergroot.

Juist onder jongeren is het erg om langere tijd niet te werken. Zij krijgen zo gemakkelijk het stigma onbetrouwbaar te zijn. Zij kunnen dan ook niet leren om een regelmatig dagritme aan te houden. Het solliciteren en vervolgens afzeggingen ontvangen motiveert niet om het te blijven proberen, zodat op een gegeven moment de hoop op een baan wordt opgegeven en de werkloosheidssituatie duurzaam dreigt te worden. Zo kan een potentieel goed functionerende werknemer over de tijd heen in een probleemgeval veranderen. Dit is funest, te meer als het om een jong persoon gaat, dat eigenlijk nog de komende veertig jaar in de arbeidsmarkt zou moeten participeren.

Een bijzondere groep vormen de voortijdig schoolverlaters. Zij sluiten hun opleiding niet af en stromen zonder afgeronde opleiding de arbeidsmarkt op. In tijden van hoogconjunctuur kunnen zij vaak ongeschoold werk verrichten en 'direct geld verdienen'. Zij bouwen dan echter nauwelijks enige kennis op. Zodra zij ontslagen worden, staan zij zonder enige certificering van hun eventueel opgedane kennis op straat. Indien de opgedane ervaring op zich onvoldoende is om door te stromen naar een nieuwe functie komen zij in de werkloosheid terecht die zonder enige opleiding moeilijk te verlaten is.

\section{Duale arbeidsmarkten}

Een aan het bovenstaande gerelateerde opvatting is de theorie van de duale arbeidsmarkten. Hierbij vormt het bestaan van een primaire, goede sector naast een secundaire, slechte sector een gegeven.

De primaire arbeidsmarkt wordt gekenmerkt door te nemen carrièrestappen, het doen van investeringen in al dan niet bedrijfsspecifiek menselijk kapitaal en stijgende 
Ionen over de duur van de baan. ${ }^{13}$ Ook de baanzekerheid is hier groter, omdat zowel de onderneming als de werknemer investeren in specifieke kennis of het opdoen van productieve ervaring in het beroep. Op de primaire arbeidsmarkt heeft men met langdurige contracten, carrières en productiviteitsverhogende leereffecten (ervaring) te maken. Terwijl de secundaire sector slechts 'fysieke productiviteit' betaalt, er geen leereffecten zijn of promotiemogelijkheden, geen opbouw van ervaring en korte termijn contracten. De levensloop of loon-tenure verhouding kan geschetst worden aan de hand van in figuur 6.1. De dikkere lijn geeft het leeftijdsverloop van het loon (de productiviteit) weer van een hypothetische werknemer in de primaire arbeidsmarkt. Duidelijk is te zien dat de primaire arbeidsmarkt een met de leeftijd stijgend loonverloop vertoont. Deze effecten zijn (voornamelijk) het gevolg van de geboden mogelijkheid tot leereffecten in de primaire sector.

De dunnere lijn geeft het loonverloop weer op de secundaire arbeidsmarkt. Hier is geen leereffect te zien. Weliswaar geeft de lijn een lichte stijging rond de middelbare leeftijd aan - maar dit is het resultaat van de op deze leeftijd fysieke productiviteit. De productiviteit wordt duidelijk minder met het bereiken van een hogere leeftijd. Dit is het gevolg van het type banen op de secundaire arbeidsmarkt, die slechts de bij werknemers aanwezige fysieke productiviteit benutten, en geen gelegenheid bieden om (structurele) leerervaring op te bouwen. De grafiek geeft weer dat de fysieke krachten en de gezondheid van de werknemers afneemt bij stijgende leeftijd. Zeker als de werknemers in beroepen werken die fysiek zwaar of gevaarlijk zijn.

Op de secundaire arbeidsmarkt is het niet belangrijk om bij dezelfde werkgever in dienst te blijven, aangezien de productiviteit onafhankelijk is van de opgedane ervaring, dus onafhankelijk is van opgebouwd specifiek menselijk kapitaal. Let wel dat wij tot nog toe niet geïmpliceerd hebben dat hoger opgeleide werknemers noodzakelijkerwijs in de primaire arbeidsmarkt terechtkomen, terwijl voor laag opgeleide werknemers slechts de secundaire arbeidsmarkt voorbehouden blijft. In Brunello (1996) wordt een verband gelegd tussen scholingsniveau en duale arbeidsmarkten en met interne carrières binnen bedrijven. Werknemers kunnen volgens zijn argumentatie in beide, de primaire of secundaire arbeidsmarkt, of (hoger) geschoold zijn of ongeschoold. Bedrijven hebben voor de primaire arbeidsmarkt getraind personeel nodig. De trainingkosten zijn lager voor geschoolde werknemers dan voor ongeschoolde, en de ontvangen training is specifiek voor het bedrijf.

Brunello laat zien dat laag opgeleide werknemers aan het begin van hun carrière ook kans maken op een carrière, maar indien zij er niet in slagen om in de primaire, goede, arbeidsmarkt terecht te komen of eruit ontslagen worden, vallen zij terug naar de secundaire arbeidsmarkt, of in de werkloosheid. Voor (hoger) opgeleide werknemers bestaat ook na ontslag uit de primaire arbeidsmarkt de kans om een nieuwe baan in de primaire arbeidsmarkt te vinden.

13. Een vergelijkbaar beeld wordt door Bewley (1999) geschetst. In zijn op interviews gebaseerde, empirische studie over de loonrigiditeit is de secundaire sector gekenmerkt door kortdurende en deeltijd banen. Hij vindt een hoger verloop van personeel, die volgens de interviews ook door de personeelsfunctionarissen gewenst zijn. 


\subsection{Probleemgroepen in Overijssel en Nederland}

Nadat de bevindingen uit de economische literatuur over de problemen aan de onderkant van de arbeidsmarkt geschetst zijn, is het tijd om enig empirisch inzicht te verwerven in de voor Overijssel relevante situatie. In figuur 6.2 geven wij de leeftijdsopbouw weer van de werkloze beroepsbevolking in Overijssel van 1996 tot 2002. De eerste probleemgroep aan de onderkant zouden de jongere werklozen zijn. Dat zijn de leeftijdsgroepen van 15-19, maar ook van 20-29. Schoolverlaters zouden - zoals eerder gezegd - zo snel mogelijk geïntegreerd moeten worden in de werkende bevolking om zo de nodige praktische vaardigheden te verwerven en het geleerde te gebruiken. De tweede probleemgroep wordt gevormd door de oudere werklozen in de leeftijdsgroepen 50-59 en 60-65. Hun inzetbaarheid kan beperkt zijn door slijtage en veroudering van kennis die bovendien vaak een specifiek karakter heeft. Scholing van deze groep is duur door de korte periode waarover de baten terugverdiend moeten worden.

Figuur 6.2

Leeftijdsverdeling van werklozen in Overijssel, 1996-2002

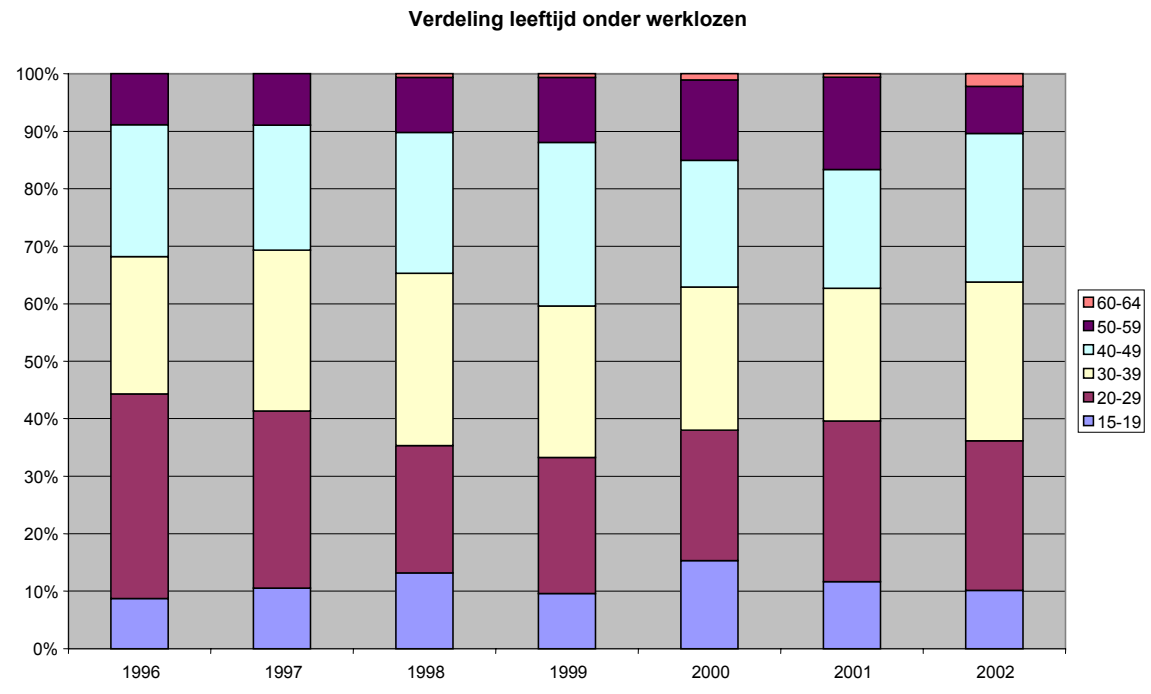

Bron: EBB

Voor de twee jongste leeftijdsgroepen samen is over de periode 1996-1999 een duidelijke vermindering van hun aandeel in de werkloze bevolking van Overijssel vast te stellen. In economisch goede tijden blijkt het makkelijker om als jongere te starten, en is de kans in de werkloosheid te belanden kleiner. Dit verandert echter in 2000 en 
Figuur 6.3

Opleidingsverdeling van werkenden, werklozen en niet participerenden in Overijssel

Werkenden Overijssel

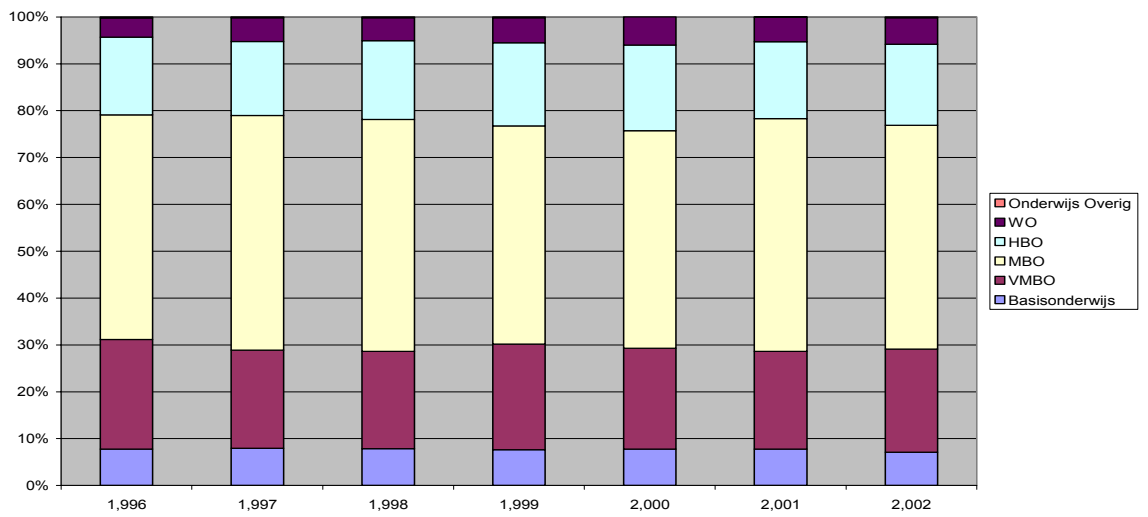

Werklozen Overijssel

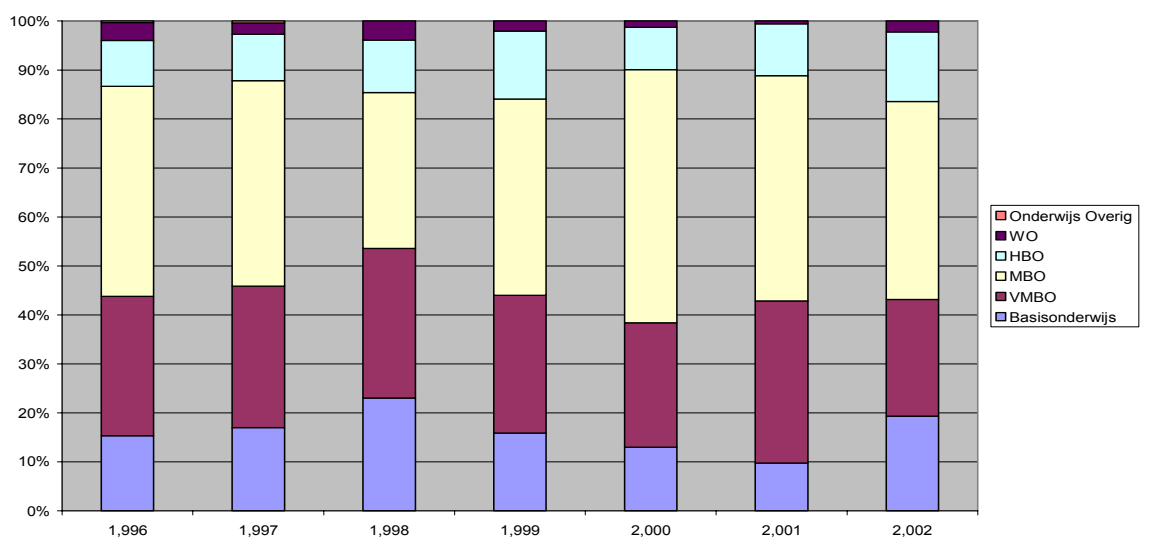

Niet participerend

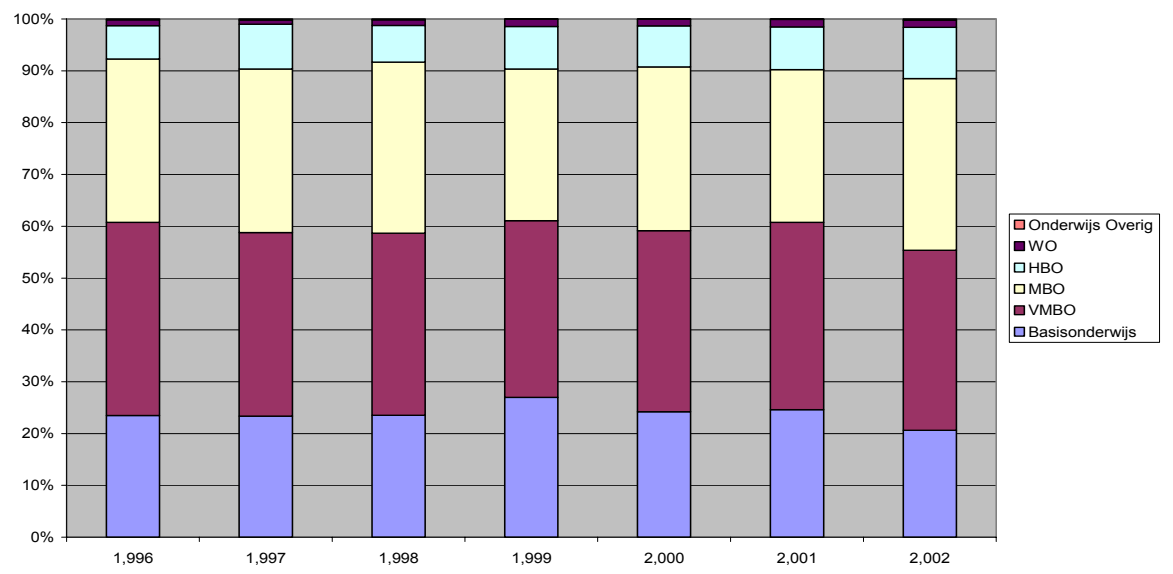

Bron: EBB 
2001 als het aandeel van de werkloze beroepsbevolking onder de 29 jaar duidelijk toeneemt, en tot 2002 stabiliseert. Dit is het gevolg van de slechtere economische situatie. Een conclusie is dan ook dat de zwakke groepen onder de jongeren waarschijnlijk, afhankelijk van de economische situatie, vaak in de werkloosheid terechtkomen. Ook de andere probleemgroep - de oudere laag opgeleide werknemer - lijkt in economisch moeilijke tijden vaker in de werkloosheid terecht te komen: Terwijl het werkloosheidsaandeel 50+'ers van 1996-1998 redelijk stabiel blijkt te zijn, groeit hun aandeel vanaf 1999. Of het terugdringen van hun aandeel in 2002 structureel is, of het gevolg van een algemeen grote instroom in de werkloosheid blijft afwachten.

Figuur 6.3 geeft de verdeling van opleidingen weer voor werkenden, werklozen, en niet-participerenden in Overijssel. Interessant is dat de verhouding van werkenden redelijk stabiel blijft over de periode van 1996 - 2002, terwijl er onder werkzoekenden en niet-participerenden iets meer dynamiek is. Hier is geen eenduidig beeld voor de probleemgroepen terug te vinden. Bij de werklozen is er namelijk in de periode 19961998 weliswaar een toenemend aandeel van laag opgeleiden te vinden, maar dit neemt weer af in de daarop volgende periode. Dit komt waarschijnlijk door de toestroom van middelbaar opgeleide werklozen in de periode 1999-2002.

Figuur 6.4

Duur van werkkring naar opleiding, Overijssel

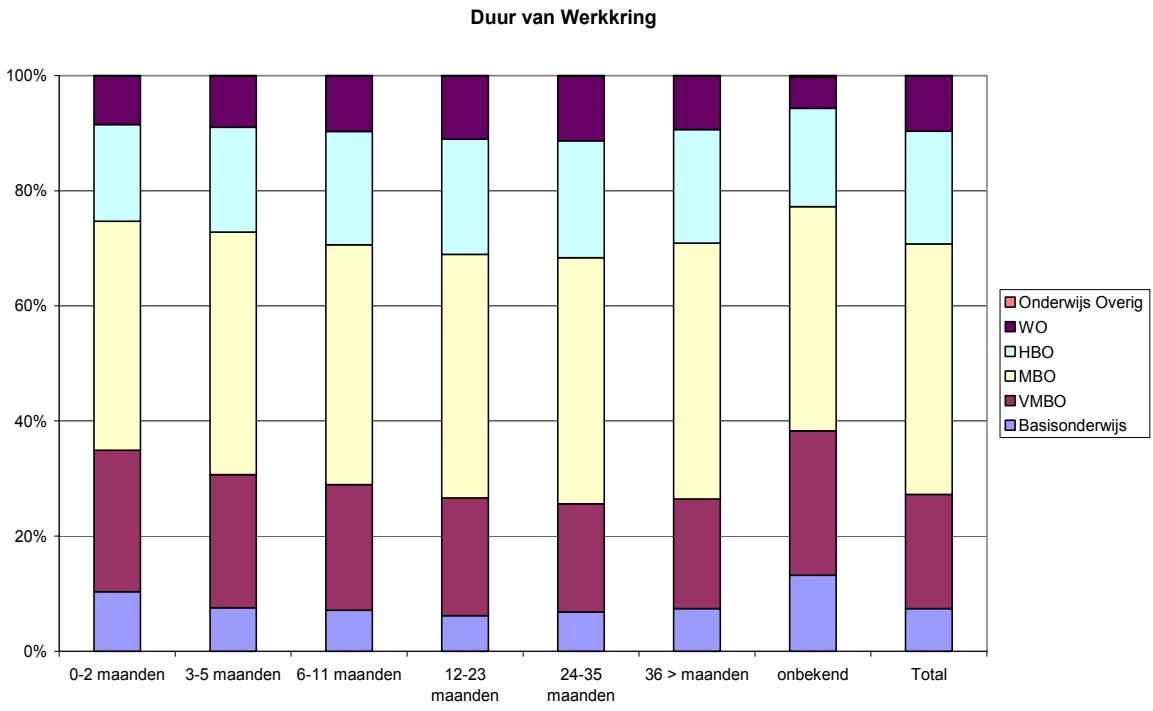

Bron: EBB 2002

Van belang is dat werkloosheid op zich geen probleem hoeft te zijn als er daarna weer een langdurige, goede werkkring gevonden kan worden. In termen van de duale arbeidsmarkt is dat dus een baan in de primaire sector. Dit is makkelijker te realiseren voor middelbaar en hoger opgeleide werknemers, zoals in figuur 6.3 te 
zien is. Lager opgeleiden of mensen zonder opleiding hebben vaker kortdurende werkrelaties en kunnen daarom geen specifieke kennis in hun baan of beroep opbouwen. Dit, terwijl zij juist de grootste behoefte aan een dergelijke opbouw van hun kennis hebben.

De relatief hoge werkloosheid en non-participatie van ongeschoolden en laag opgeleiden kan enerzijds verklaard worden uit een gebrek aan bepaalde competenties en te weinig scholing en anderzijds door de grote dynamiek aan de onderkant van de arbeidsmarkt, waardoor laag opgeleiden voortdurend het hebben van een baan afwisselen met periodes van werkloosheid. Omdat er geen Overijsselse cijfers over de werkloosheidsdynamiek beschikbaar zijn, zullen wij dit aan de hand van Nederlandse cijfers verduidelijken. Wij gebruiken hiervoor het sociaal economisch panel (SEP) van het CBS. Het fenomeen van 'draaideur-werklozen' wordt geïllustreerd in tabel 6.1. Uit de tabel blijkt dat de kans op werkloosheid onder werkenden samenhangt met het opleidingsniveau. Hoe hoger het opleidingsniveau, hoe kleiner de kans om werkloos te worden. Met name onder ongeschoolden komt herhaalde werkloosheid vaak voor. Zo is het percentage werkzoekenden met als hoogst behaald opleidingsniveau basisonderwijs of VMBO dat in de afgelopen vijf jaar drie keer of vaker werkloos is geweest, $17 \%$ van het totaal aantal werkenden op het betreffende opleidingsniveau. Voor werkzoekende MBO'ers, HBO'ers en WO'ers zijn deze percentages respectievelijk $13 \%, 12 \%$ en $9 \%$. Het opleidingsniveau heeft derhalve een grote invloed op de frequentie van werkloosheid.

Tabel 6.1

De kans om meervoudig werkloos te worden, naar opleidingsniveau, Nederland 1997-2001

\begin{tabular}{lccccc}
\hline & \multicolumn{5}{c}{ Hoe vaak werkloos in de afgelopen 5 jaar? } \\
& $\begin{array}{c}1 \text { keer } \\
\%\end{array}$ & $\begin{array}{c}2 \text { keer } \\
\%\end{array}$ & $\begin{array}{c}3 \text { keer } \\
\%\end{array}$ & $\begin{array}{c}3 \text { keer } \\
\%\end{array}$ & $\begin{array}{c}\text { totaal } \\
\%\end{array}$ \\
\hline Basisonderwijs & 74 & 9,1 & 2,6 & 14,3 & 100 \\
VMBO & 68,6 & 14,3 & 5,7 & 11,4 & 100 \\
MBO & 71,8 & 15,8 & 3,8 & 8,6 & 100 \\
HBO & 72,5 & 15 & 5,3 & 7,2 & 100 \\
WO & 71,2 & 20,3 & 2,6 & 5,9 & 100 \\
Totaal & 71,4 & 15,4 & 4,2 & 9 & 100 \\
\hline
\end{tabular}

Bron: CBS(SEP)

Een andere dimensie van de werkloosheid betreft de duur ervan. In tabel 6.2 is de werkloosheidsduur weergegeven van werkenden gedurende de afgelopen vijf jaar naar opleidingsniveau. Uit de tabel blijkt dat met name ongeschoold werkenden (basisonderwijs) die gedurende de afgelopen vijf jaar werkloos zijn geweest, significant langer werkloos waren dan de werkenden van een hoger opleidingsniveau (die eveneens werkloos zijn geweest). Bovendien blijkt dat de kans op langdurige werkloosheid daalt naarmate het opleidingsniveau stijgt. Uit de tabellen 6.1 en 6.2 blijkt derhalve dat zowel de frequentie als de duur van de werkloosheid toenemen 
naarmate werklozen lager opgeleid zijn. Dit kan erop wijzen dat bij een deel van de laag opgeleiden periodes van werkloosheid en het hebben van werk elkaar snel opvolgen en dat een ander deel van de laag opgeleide werklozen juist periodes van langdurige werkloosheid kent.

Tabel 6.2

Kans van werkenden op langdurige werkloosheid, naar opleidingsniveau, Nederland 1997-2001

\begin{tabular}{lccc} 
& \multicolumn{3}{c}{ Langer dan 1 jaar werkloos in de afgelopen } \\
& Ja & $\begin{array}{c}\text { Naren? } \\
\%\end{array}$ & $\begin{array}{c}\text { Totaal } \\
\%\end{array}$ \\
& & & \\
\hline Basisonderwijs & 60 & 40 & 100 \\
VMBO & 39 & 61 & 100 \\
MBO & 34 & 66 & 100 \\
HBO & 34 & 66 & 100 \\
WO & 29 & 71 & 100 \\
Totaal & 36 & 64 & 100 \\
\hline
\end{tabular}

Bron: CBS(SEP)

Die groepen onder de werknemers die een verhoogde kans hebben op werkloosheid, laten ook een hogere kans zien om herhaaldelijk in de werkloosheid terecht te komen (tabel 6.1). Deze groep van werknemers zorgt ervoor dat het aantal werkzoekenden en vacatures in de lagere opleidingscategorie hoog blijft. De langdurige werkloosheid is ten dele te wijten aan het niet meer actief zoeken van de werkloze. Dit 'opgeven' komt op de arbeidsmarkt vaker voor onder de laag opgeleiden. Dit verklaart waarom deze groep vaker en langer werkloos is. Hoe hoger de opleiding, hoe actiever naar een nieuwe baan gezocht wordt. Tabel 6.3 geeft een overzicht waaruit duidelijk wordt, dat - om verschillende redenen - lager opgeleide werklozen voor bijna $50 \%$ niet actief naar een nieuwe baan zoekt. Daarentegen geeft slechts $27,4 \%$ van de universitair opgeleiden aan niet actief naar nieuw werk te zoeken.

Het zoekgedrag kan natuurlijk het resultaat zijn van eerder opgedane ervaringen. In ieder geval is het niet bevorderlijk voor de transitiekansen uit de werkloosheid om niet actief te zoeken. Zo is het ook niet verbazingwekend dat de transitiekansen verschillen per opleidingsniveau. Tabel 6.4 geeft aan dat gemiddeld genomen 16,5\% van de werklozen in de laatste vier weken een baan heeft aangeboden gekregen. Het percentage werklozen, dat aangeeft banen aangeboden gekregen te hebben, is vooral onder werklozen met een minimaal opleidingsniveau van MBO te vinden. Zowel het laagste opleidingsniveau als ook het VMBO blijven hierbij duidelijk achter. Dit terwijl er voor laag opgeleiden (VMBO en lager) relatief meer vacatures waren dan voor de hogere opleidingsniveaus. 
Tabel 6.3

Zoekgedrag werklozen, Nederland 1997-2001

\begin{tabular}{lcc}
\hline & & Actief zoeken \\
& Ja & Neen \\
\hline Basis & 50,6 & 49,4 \\
VMBO & 51,1 & 48,9 \\
MBO & 67,0 & 33,0 \\
HBO & 70,4 & 29,6 \\
WO & 72,6 & 27,4 \\
Totaal & & 35,2 \\
\hline Bron:
\end{tabular}

Bron: CBS(SEP)

Tabel 6.4

Transitiekansen werklozen, Nederland 1997-2001, percentage

\begin{tabular}{lcc}
\hline & $\begin{array}{c}\text { Baan aangeboden in laatste } \\
\text { Ja }\end{array}$ & $\begin{array}{c}\text { weken } \\
\text { Neen }\end{array}$ \\
\hline Basis & 6,6 & 93,4 \\
VMBO & 13,5 & 86,5 \\
MBO & 17,2 & 82,8 \\
HBO & 19,7 & 80,3 \\
WO & 17,1 & 82,9 \\
\hline Totaal & 16,5 & 83,5 \\
\hline Bron: SEP 1997-2001 & &
\end{tabular}

\subsection{Invloed conjunctuur op de werkgelegenheid aan de onderkant}

In de scenario's van hoofdstuk 5 konden wij zien dat de onderliggende economische groei van groot belang is voor de uitbreidingsvraag in de verschillende sectoren en beroepen. In dit hoofdstuk is het vooral belangrijk om na te gaan hoe de omvang van de werkgelegenheid in een beroep of opleiding door de verschillende scenario's beïnvloed wordt. 
Tabel 6.5

Scenario-analyse voor beroepen, verandering werkgelegenheid 2003-2008, percentage van werkenden in 2002

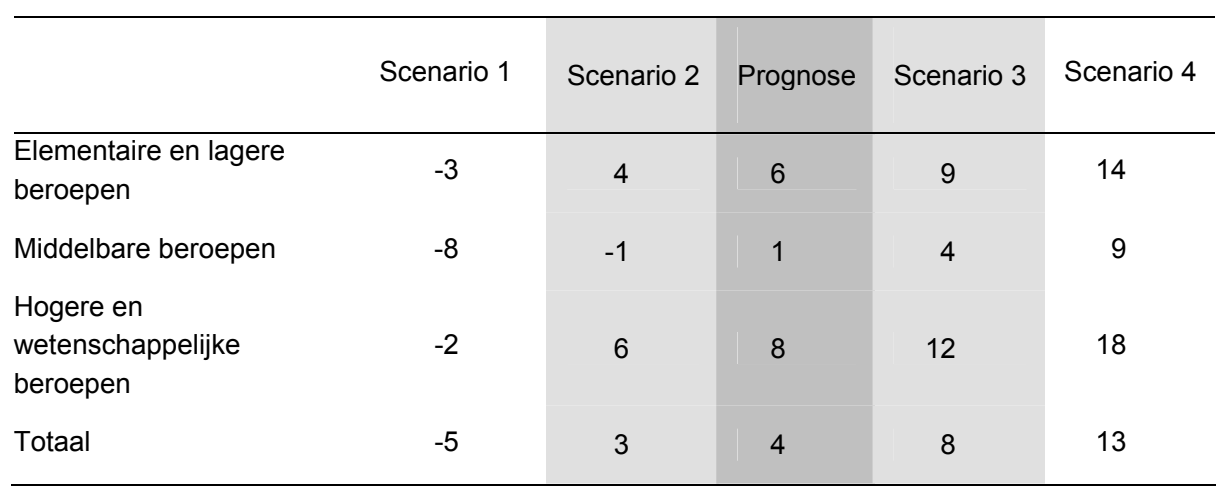

In tabel 6.5 is duidelijk te zien dat de lagere beroepen, maar vooral ook de middelbare beroepen getroffen worden door de economische situatie. Terwijl zij qua werkgelegenheid flink groeien bij een voorspoedige economische ontwikkeling, krimpen zij ook net zo hard als de economische groei tegenvalt. In tabel 6.6 is te zien dat de werving voor de verschillende beroepscategorieën ten koste gaat van de laagst opgeleiden. Hoe slechter de economische situatie hoe groter de krimp onder de werknemers met Basisonderwijs of VMBO. Hieruit valt te concluderen dat werkgevers proberen om vooral hoger en middelbaar opgeleide werknemers in dienst te houden, ook al zitten zij op functies die ook door lager opgeleiden vervuld kunnen worden.

Tabel 6.6

Scenario-analyse voor opleidingen, verrandering werkgelegenheid 2003-2008, percentage van werkenden in 2002

\begin{tabular}{lrrrrr}
\hline & Scenario 1 & Scenario 2 & Prognose & Scenario 3 & Scenario 4 \\
\hline Basisonderwijs & -28 & -21 & -20 & -17 & -12 \\
VMBO & -10 & -4 & -2 & 1 & 6 \\
MBO & 0 & 8 & 9 & 13 & 18 \\
HBO & 1 & 9 & 10 & 14 & 20 \\
WO & 1 & 12 & 14 & 20 & 28 \\
Totaal & -5 & 3 & 4 & 8 & 13 \\
\hline
\end{tabular}

\subsection{Conclusies en beleidsopties}

In voorgaande discussie werd erop gewezen dat laag opgeleiden - de door ons gedefinieerde onderkant - slechts dan goed kunnen functioneren op de arbeidsmarkt als zij langdurige arbeidsrelaties kunnen aangaan. Bedreigend voor laag opgeleiden is als zij een combinatie van 'probleemkenmerken' met zich meebrengen. Zo zijn jonge voortijdig schoolverlaters niet alleen laag opgeleid, maar zij hebben ook nog geen ervaring en kennis opgebouwd op de arbeidsmarkt. Indien deze probleem- 
groepen in de werkloosheid terecht komen, is het van belang om deze daar zo kort mogelijk te houden, om een draaideur- of langdurige werkloosheid te voorkomen.

Bij een duale arbeidsmarkt waarbij slechts op de primaire arbeidsmarkt ervaring opgebouwd kan worden, is het duidelijk dat er tijdens het arbeidsleven van een werknemer op den duur problemen kunnen ontstaan. Werknemers in de secundaire sector zullen namelijk op hogere leeftijd door slijtage een lagere productiviteit hebben (zie figuur 6.1), die mogelijk onder het minimumloon komt te liggen of waarbij het herstel van verloren capaciteiten niet meer loont. ${ }^{14}$ Hierdoor kunnen werknemers op een hogere leeftijd in de werkloosheid terecht komen, en zich mogelijk volledig uit de arbeidsmarkt terugtrekken.

Conceptueel zouden leerplekken voor laaggeschoolde (jonge) werknemers en de kosten voor het deelnemende bedrijf gesubsidieerd moeten worden, zodat laaggeschoolde werknemers zich naar een hogere of andersoortige opleiding kunnen opscholen of omscholen. De trend op middellange termijn is naar een afnemende vraag naar ongeschoolden bij bedrijven, als ook een afname van de vraag naar laag opgeleiden (VMBO). In tabel 1.1 van hoofdstuk 1 was duidelijk te zien dat de uitbreidingsvraag negatief was voor beide groepen. Werknemers met een middelbare beroepsopleiding daarentegen kunnen in veel gevallen wel een positieve uitbreidingsvraag tegemoet zien. Hier is dus een duidelijke behoefte om ongeschoolden en met name laag opgeleiden te helpen op MBO niveau te komen. Maar ook binnen de MBO opleidingen zijn er duidelijke verschillen in arbeidsmarktperspectief (zie bijvoorbeeld figuur 4.1 in hoofdstuk 4). Zo biedt MBO Natuur en techniek betere vooruitzichten en tevens hogere substitutiemogelijkheden tussen beroepen dan MBO Dienstverlening en gezondheidszorg. Het opscholen van VMBO Economie naar MBO Economie verbetert ook duidelijk de vooruitzichten van lager opgeleiden. Een verbetering van perspectief wordt ook bereikt bij het opscholen van VMBO Natuur en techniek naar MBO Natuur en techniek. Indien men naar specifiekere opleidingen kijkt zijn deze verschillen in arbeidsmarktvooruitzichten en perspectieven voor op- of omscholing nog duidelijker te zien. Leerlingen of jongeren die werkloos zijn en gezien hun opleidingsachtergrond ongunstige arbeidsmarktperspectieven hebben, zouden dan ook geadviseerd moeten worden om zich om te scholen of nog beter op te scholen naar perspectiefvolle opleidingen.

14. CAO lonen op lage salarisschalen zijn vaak gebaseerd op een opslag op de wettelijke minimumloon 


\section{Geografische mobiliteit en werkgelegenheid}

\subsection{Inleiding}

In dit hoofdstuk komen drie verschillende invalshoeken aan de orde voor de geografische mobiliteit van werkenden op de Overijsselse arbeidsmarkt. In paragraaf 7.2 wordt gekeken naar de regio waar schoolverlaters en afgestudeerden van een Overijsselse onderwijsinstelling terechtkomen als ze een baan gevonden hebben. Dit wordt bezien in samenhang met de aansluiting tussen onderwijs en arbeidsmarkt. In paragraaf 7.3 wordt ingegaan op de mobiliteitsontwikkeling van 1991 tot 2001. In paragraaf 7.4 wordt nagegaan of en in welke mate aanpassingen in regionale mobiliteitsstromen een oplossing kunnen zijn voor tekorten en overschotten op de Overijsselse arbeidsmarkt. In deze paragraaf worden twee soorten stromen onderscheiden. De ene stroom betreft de schoolverlaters die na hun afstuderen een baan vinden in Overijssel of daar buiten. De andere stroom betreft de inkomende pendelaars die buiten Overijssel wonen, maar in Overijssel werkzaam zijn.

\subsection{Mobiliteit van schoolverlaters}

Mobiliteit en passende baan?

Verschillen tussen vraag en aanbod van arbeid kunnen leiden tot werkloosheid of onvervulde vacatures. Om werkloosheid te voorkomen kunnen werkzoekenden hun zoekgedrag aanpassen door een baan te accepteren die minder goed aansluit bij de verworven kennis en vaardigheden. Er bestaat veel literatuur over deze aanpassing van werkzoekenden. Hierbij ligt de nadruk op overscholing: het hebben van een baan beneden het behaalde opleidingsniveau. Overscholing is in de belangstelling van onderzoekers komen te staan vanwege het feit dat in de afgelopen decennia het gemiddelde opleidingsniveau van de Nederlandse beroepsbevolking is gestegen, terwijl het niveau van de beschikbare banen niet in gelijke mate is toegenomen. ${ }^{15}$ Hierdoor zijn steeds meer personen in Nederland werkzaam in banen onder het behaalde opleidingsniveau. Naast acceptatie van een baan onder het behaalde opleidingsniveau, kunnen werkzoekenden om werkloosheid te voorkomen hun zoekgedrag ook aanpassen door een baan buiten de opleidingsrichting te accepteren. ${ }^{16}$ De mate waarin een baan aansluit bij het behaalde opleidingsniveau, de gevolgde opleidingsrichting, de beloning of de zekerheid die een baan biedt, zoals

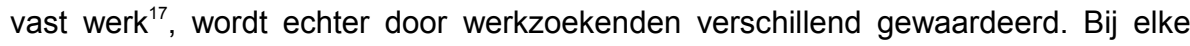
vacature die werkzoekenden tegenkomen wordt dan ook een afweging gemaakt, waarbij de verschillende aanpassingen tegen elkaar worden afgezet.

15. Asselberghs et al, 1998; Wolbers, de Graaf \& Ultee, 2001.

16. Wolbers, 2003.

17. Kalleberg, Reskin \& Hudson, 2000. 
Volgens Büchel \& van Ham (2003) wordt in onderzoek naar overscholing van werknemers de rol van de geografische mobiliteit over het hoofd gezien. De kans op overscholing kan worden verminderd wanneer werkzoekenden bereid zijn een grotere afstand af te leggen om de werklocatie te bereiken. Deze grotere afstand kan afgelegd worden door te pendelen of te verhuizen. Doordat regio's in Nederland worden gekenmerkt door lokale arbeidsmarkten die verschillen in vraag en aanbod van arbeid, hebben werkzoekenden een grotere kans een baan te vinden die aansluit bij de door hen gevolgde opleiding (qua niveau en/of -richting) als hun zoekgebied meerdere lokale arbeidsmarkten omvat. Over het algemeen geldt dan ook dat degenen die zoeken naar vacatures op de landelijke arbeidsmarkt vaker een passende baan vinden dan degenen die alleen op de lokale arbeidsmarkt zoeken. Aangezien niet iedereen bereid is voor het werk over een grote afstand te pendelen of te verhuizen, kan geografische mobiliteit worden beschouwd als één van de aanpassingen die werkzoekenden meewegen bij de keuze voor een baan.

In deze paragraaf wordt gekeken naar de rol die geografische mobiliteit speelt bij de inpassing van schoolverlaters in het arbeidsproces. Dit wordt gedaan voor schoolverlaters van het $\mathrm{VMBO}$, de $\mathrm{BOL}$, de $\mathrm{BBL}$ en het $\mathrm{HBO}^{18}$. Per provincie wordt de geografische mobiliteit van schoolverlaters in beeld gebracht en wordt aangegeven welk deel van de schoolverlaters een (bij de opleiding) passende baan heeft gevonden. Hiertoe worden vier kenmerken van de banen van schoolverlaters bekeken: (1) een baan die past bij het behaalde opleidingsniveau (baan op niveau); (2) een baan die past bij de gevolgde opleidingsrichting (baan in de richting); (3) een vaste baan en (4) een voltijdbaan. Deze kenmerken geven een indicatie van de mate van inpassing in het arbeidsproces.

Voor de analyse zijn zes uitstroomcohorten samengenomen. Deze hebben betrekking op de meetjaren 1996 tot en met 2001 van de RUBS-enquête en de HBOMonitor. In de analyse is geselecteerd op gediplomeerde schoolverlaters tussen 16 en 30 jaar, die een voltijdse opleiding hebben gevolgd en na het verlaten van het onderwijs betaald werk hebben gevonden.

\section{Geografische mobiliteit en inpassing in het arbeidsproces}

Verschillen tussen vraag en aanbod van arbeid op lokale arbeidsmarkten leiden ertoe dat werkzoekenden worden geconfronteerd met discrepanties op lokale arbeidsmarkten. Een deel van de schoolverlaters zal worden geconfronteerd met werkloosheid of een baan die minder goed aansluit bij de gevolgde opleiding.

18. Schoolverlaters van het HAVO, VWO en het WO worden buiten beschouwing gelaten in dit hoofdstuk. Voor het HAVO en VWO geldt dat zeer weinig schoolverlaters doorstromen naar de arbeidsmarkt. Hierdoor bevinden zich relatief weinig HAVO- en VWOschoolverlaters in onze onderzoekspopulatie. De resultaten van de analyse voor deze groep schoolverlaters worden daarom niet voldoende betrouwbaar geacht. Voor het WO geldt dat universiteiten niet gelijk zijn verdeeld over Nederland. WO'ers zijn daarom niet meegenomen in de analyse. 
Figuur 7.1

Geografische mobiliteit van schoolverlaters per RPA(34)-gebied

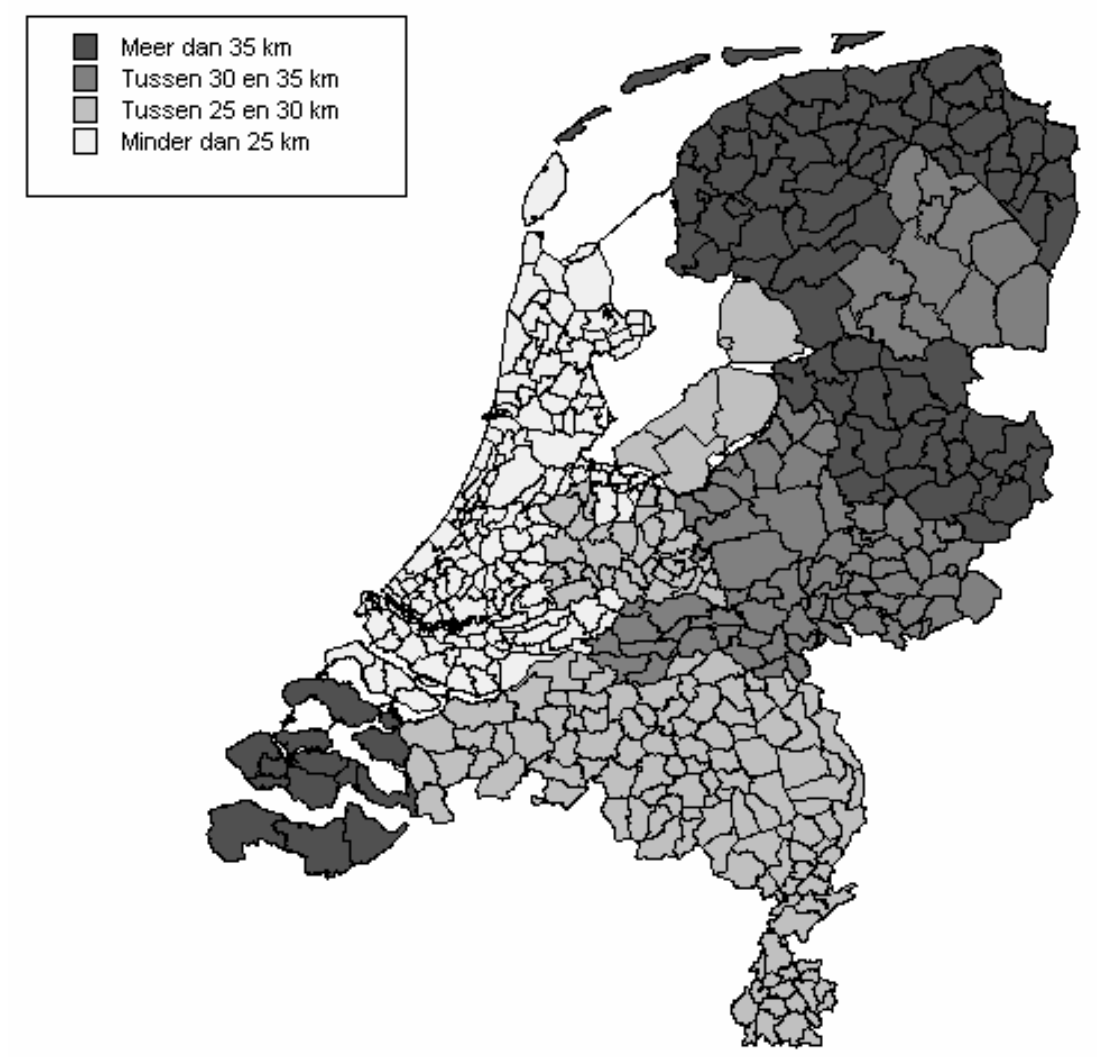

Bron: ROA(SIS)

Figuur 7.1 geeft een overzicht van de regionale verschillen in geografische mobiliteit voor schoolverlaters in Nederland. Hiervoor is per provincie de gemiddelde geografische mobiliteit van schoolverlaters bepaald. In tabel 7.1 is de geografische mobiliteit van schoolverlaters cijfermatig weergegeven. De geografische mobiliteit van schoolverlaters is bepaald aan de hand van de afstand ${ }^{19}$ (in kilometers) tussen de gemeente waar de schoolverlater de opleiding heeft gevolgd en de gemeente waar de schoolverlater een baan heeft gevonden. ${ }^{20}$ Het algemene beeld dat uit figuur 7.1 naar voren komt is dat de gemiddelde afstand tussen de gemeente waar men de opleiding heeft gevolgd en de gemeente waar men gaat werken het grootst is voor schoolverlaters in het noorden van Nederland en Zeeland. Daarna volgen schoolverlaters uit het oosten en zuiden van Nederland. Schoolverlaters uit het westen van

19. Hierbij wordt de afstand tussen twee gemeenten bepaald als de kortste goniometrische afstand.

20. De afstand tussen de gemeente waar de opleiding is gevolgd en de huidige werkgemeente verschilt van de afstand tussen woon- en werkgemeente. Het betreft dus de mobiliteit ten opzichte van de schoollocatie. 
Nederland zijn geografisch gezien het minst mobiel. Een mogelijke verklaring hiervoor zou kunnen zijn dat de lokale arbeidsmarkt voor schoolverlaters in het Westen doorgaans groter is dan de lokale arbeidsmarkt voor schoolverlaters in het Noorden.

Tabel 7.1 laat zien dat de gemiddelde afstand tussen de gemeente waar de opleiding gevolgd is en de gemeente waar gewerkt wordt voor schoolverlaters in Friesland maar liefst 48 kilometer bedraagt. Dit betekent dat veel schoolverlaters die in Friesland een opleiding gevolgd hebben buiten Friesland werkzaam zijn. Daarnaast zijn ook schoolverlaters uit de provincie Groningen relatief mobiel (44 kilometer). Dit geldt niet voor schoolverlaters afkomstig uit de provincies Noord-Holland en ZuidHolland. De gemiddelde afstand tussen de gemeente waar de opleiding gevolgd is en de gemeente waar gewerkt wordt, is voor schoolverlaters in deze provincies minder dan 20 kilometer.

Daarnaast worden in tabel 7.1 de regionale verschillen vermeld in de kans op een baan op niveau, een baan in de richting, vast werk en een voltijd baan. Vast werk betekent hier dat schoolverlaters geen flexibele arbeidsrelatie hebben, dat wil zeggen niet werkzaam zijn als uitzendkracht, oproepkracht e.d. of werkzaam zijn in een tijdelijke aanstelling. Hieruit blijkt dat de kans op het vinden van een bij de opleiding passende baan duidelijk verschilt per provincie.

Tabel 7.1

Geografische mobiliteit en vier kenmerken van de inpassing van schoolverlaters in het arbeidsproces, naar provincie

\begin{tabular}{lccccc}
\hline Provincie & Mobiliteit & $\begin{array}{c}\text { Baan op } \\
\text { niveau } \\
\%\end{array}$ & $\begin{array}{c}\text { Baan in } \\
\text { richting } \\
\%\end{array}$ & Vast werk & Voltijdbaan \\
& Km. & & & $\%$ & $\%$ \\
\hline Groningen & 45 & 72 & 70 & 73 & 65 \\
Friesland & 48 & 68 & 64 & 72 & 70 \\
Drenthe & 32 & 64 & 57 & 81 & 69 \\
Overijssel & 39 & 71 & 74 & 85 & 74 \\
Gelderland & 31 & 74 & 74 & 80 & 69 \\
Flevoland & 29 & 67 & 62 & 71 & 51 \\
Utrecht & 26 & 74 & 73 & 83 & 75 \\
Noord Holland & 17 & 70 & 65 & 83 & 76 \\
Zuid Holland & 20 & 75 & 69 & 85 & 76 \\
Zeeland & 37 & 64 & 72 & 86 & 72 \\
Noord Brabant & 26 & 72 & 74 & 86 & 79 \\
Limburg & 29 & 69 & 69 & 81 & 75 \\
Totaal & & & & & \\
Bron: ROA/SIS & 28 & 71 & 70 & 83 & 75 \\
\hline
\end{tabular}

De inpassing van Overijsselse schoolverlaters in het arbeidsproces is doorgaans redelijk gunstig. Overijsselse schoolverlaters leggen gemiddeld een afstand van 39 
kilometer af om een baan te vinden en zijn daarmee relatief veel mobieler dan de gemiddelde schoolverlater (28 kilometer). De inpassing in het arbeidsproces verloopt voor de Overijsselse schoolverlaters doorgaans beter dan gemiddeld ten aanzien van de richting van de baan en het soort arbeidscontract. Zo heeft $74 \%$ van de schoolverlaters een baan in de richting van de gevolgde opleiding gevonden. Tevens blijkt dat $85 \%$ van de schoolverlaters die in Overijssel een opleiding gevolgd hebben, een vaste baan hebben. Overijsselse schoolverlaters hebben echter een relatief lagere kans op het vinden van een baan op het niveau van de gevolgde opleiding of een voltijdbaan

\subsection{Ontwikkeling in de mobiliteit 1991-2001}

De gemiddelde afstand tussen woning en werk neemt de laatste tijd gestaag toe. Omdat mensen steeds vaker verder weg van hun werk wonen, komt het ook steeds vaker voor dat mensen in een andere provincie wonen dan ze werken. Werkgelegenheid in Overijssel betekent daarom niet alleen werk voor mensen die in de provincie wonen, maar trekt ook werkenden aan uit naburige provincies. Omgekeerd profiteren mensen die in Overijssel wonen ook van de werkgelegenheidsontwikkelingen in naburige provincies.

Figuur 7.2

Ontwikkeling reisafstand 1991-2001

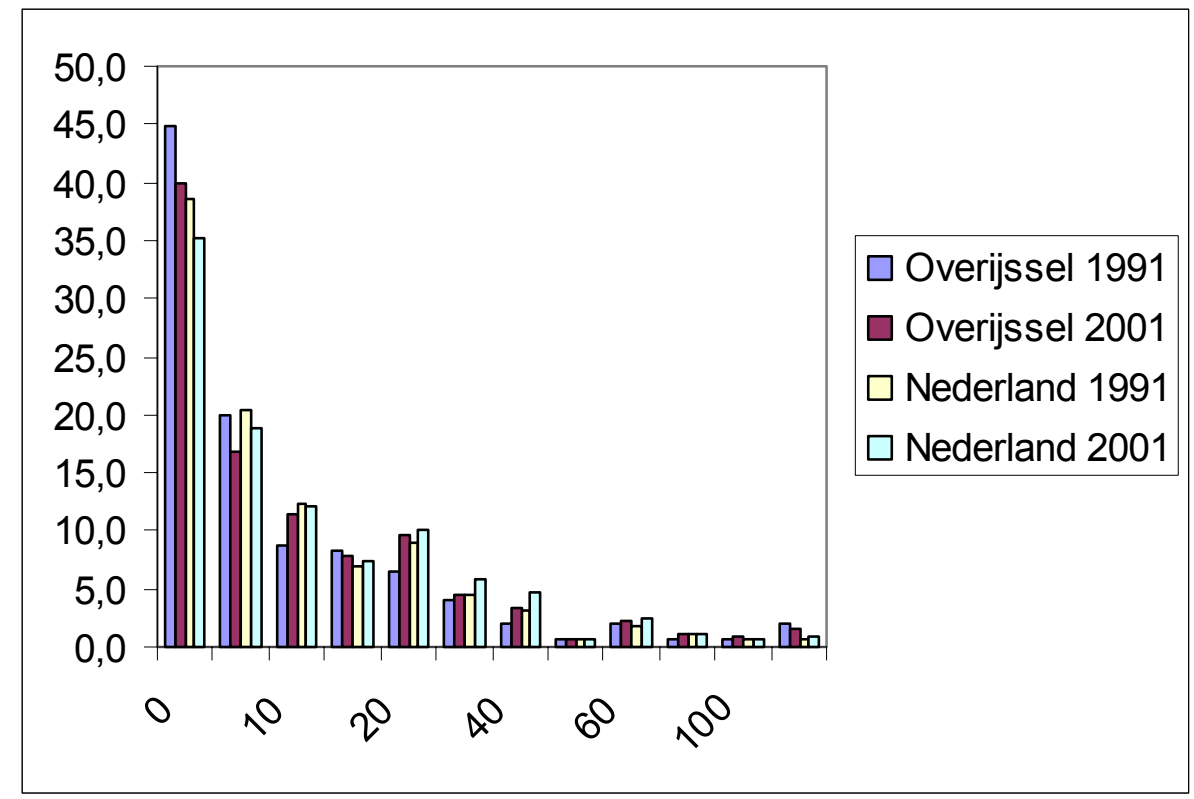

Bron: CBS

In figuur 7.2 wordt getoond hoe de reisafstand van werkenden in de provincie zich tussen 1991 en 2001 heeft ontwikkeld. De grafiek geeft de frequentie weer van de verschillende reisafstanden van werkenden in Overijssel en de rest van Nederland. In vergelijking met de rest van Nederland blijken mensen in Overijssel dichter bij hun 
werk te wonen. In 1991 woonde $45 \%$ van de werkenden in Overijssel minder dan 5 kilometer van het werk. Landelijk lag dit percentage op $38 \%$. Inmiddels is dit gedaald tot $35 \%$. Conform de landelijke ontwikkelingen is het percentage werkenden in Overijssel dat minder dan 5 kilometer van het werk woont afgenomen van 45 naar $40 \%$. Ook het aantal mensen dat op hoogstens 10 kilometer van het werk woont neemt gestaag af. In Overijssel is het percentage mensen dat 10-25 of 20-30 kilometer van het werk woont flink gestegen.

Tabel 7.2

Gemiddelde reisafstand Overijssel, 1991 en 2001

\begin{tabular}{llcll}
\hline & $\begin{array}{l}\text { Afstand } \\
1991\end{array}$ & 2001 & $\begin{array}{l}\text { Reistijd } \\
1991\end{array}$ & 2001 \\
\hline Noord-Overijssel & 14,4 & 16,9 & 19,0 & 22,8 \\
Zuidwest-Overijssel & 13,4 & 13,8 & 18,5 & 20,7 \\
Twente & 10,7 & 11,8 & 18,7 & 19,8 \\
Totaal & 12,2 & 13,8 & 18,8 & 20,9 \\
\hline
\end{tabular}

Bron: CBS

Tabel 7.2 geeft een overzicht van de gemiddelde reisafstanden in 1991 en 2001. De gemiddelde reisafstand in Overijssel is gestegen van 12,2 naar 13,8 kilometer. Met name in Noord-Overijssel is de gemiddelde reisafstand fors gestegen. In 1991 woonden de werkenden in Noord-Overijssel gemiddeld 14,4 kilometer van hun werk. In 2001 is dat 16,9 kilometer. Met het toenemen van de reisafstanden zijn ook de reistijden toegenomen. In 1991 deden werkenden uit Overijssel er gemiddeld 18,8 minuten over om op hun werk te komen. In 2001 is dit gestegen tot 20.9. Ook in reistijden is de grootste toename te vinden in Noord-Overijssel.

Veelal wordt gedacht dat ook de toegenomen congestie een grote invloed heeft op de reistijden. Het effect hiervan op de reistijden in Overijssel blijkt echter zeer gering te zijn. Figuur 7.3 laat voor verschillende afstanden de gemiddelde snelheid in kilometer per uur zien waarmee mensen de reis van huis naar werk afleggen. Korte afstanden gaan vaak per voet of met de fiets, waardoor hier de snelheid nog geen 20 kilometer per uur is. Naarmate de afstand groter wordt, wordt uiteraard ook de snelheid hoger. Doorgaans ligt de gemiddelde snelheid bij reizen in een bepaalde afstandcategorie in Overijssel iets hoger dan in de rest van Nederland, maar het verschil is maar klein. In de vergelijking tussen 1991 en 2001 blijken de snelheden vrijwel onveranderd te zijn. De toegenomen reistijd is dus vrijwel geheel het gevolg van het feit dat mensen gemiddeld steeds verder van hun werk wonen. 
Figuur 7.3

Relatie afstand en snelheid woon-werk verkeer, Overijssel en Nederland, 1991 en 2001

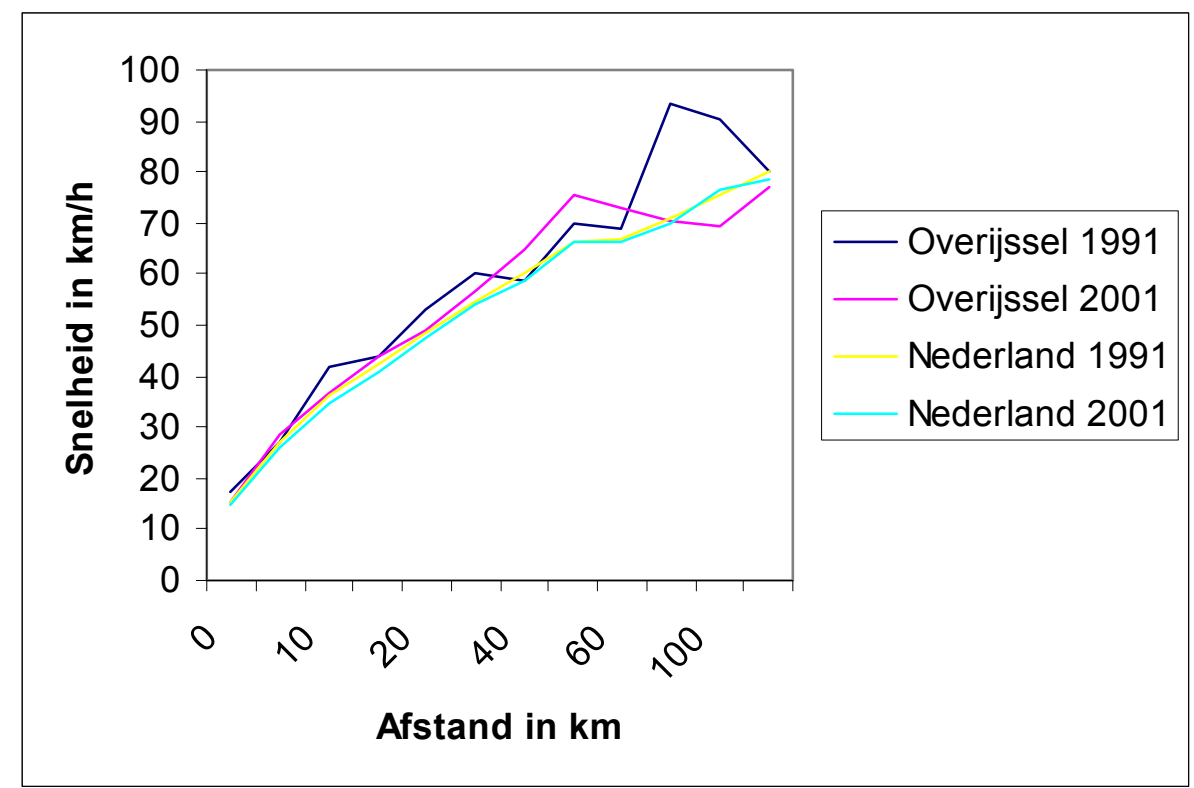

Bron: CBS

Figuur 7.4

Vertrektijd en afstand woon-werkverkeer, Overijssel en Nederland, 1991 en 2001

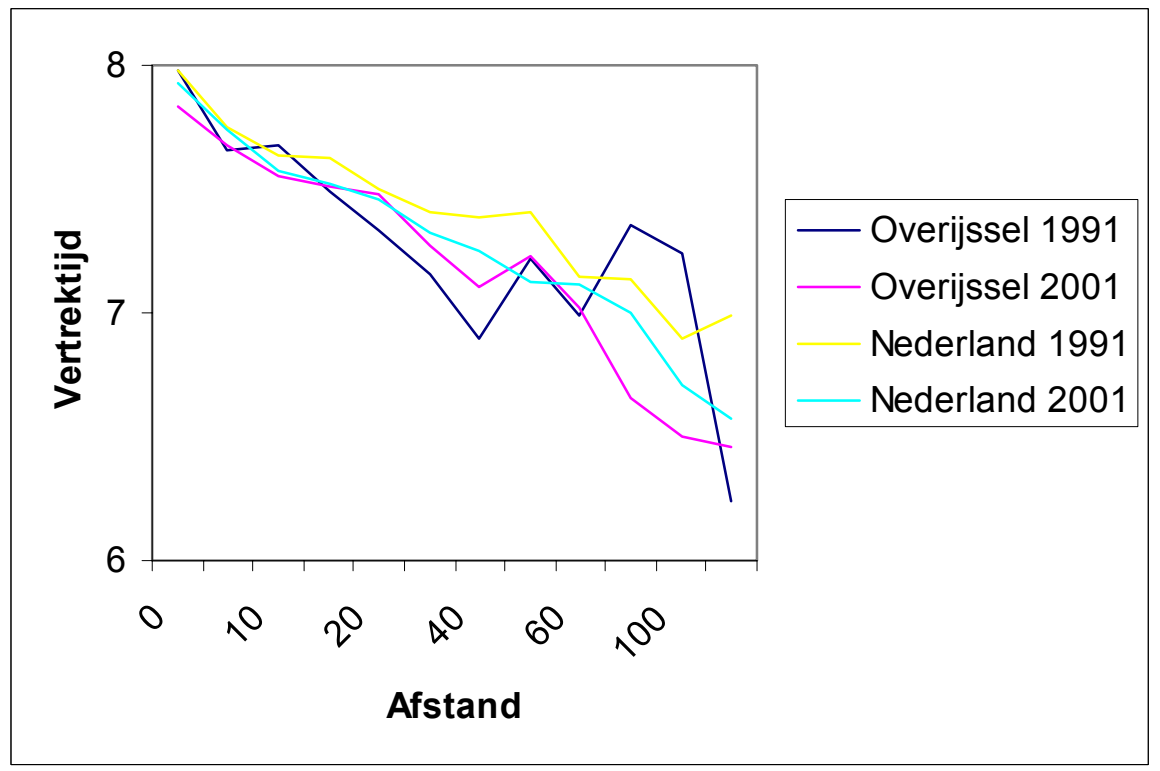

Bron: CBS 
Een consequentie hiervan is dat werkenden in de provincie steeds vroeger op pad gaan. Figuur 7.4 geeft een beeld van de gemiddelde vertrektijd, opnieuw verdeeld naar afstandscategorie. Mensen die heel dicht bij hun werk wonen, gaan gemiddeld rond 8 uur van huis. $\mathrm{Bij}$ afstanden boven de 50 kilometer vertrekt men gemiddeld rond 7 uur of eerder. In Overijssel blijken werkenden die lange afstanden moeten overbruggen gemiddeld iets eerder te vertrekken dan in de rest van het land. In 1991 vertrok 25,9\% van de werkenden voor 7 uur. In 2001 is dat percentage gestegen tot $27,7 \%$. Landelijk is deze toename sterker geweest. In 1991 vertrok 22,6\% van de werkenden voor 7 uur. In 2001 is dat $28,3 \%$.

Tabel 7.3

Pendel vanuit Overijssel, 1991 en 2001, percentage werkenden

\begin{tabular}{|c|c|c|c|c|c|c|c|c|}
\hline & \multicolumn{2}{|c|}{ N-Overijssel } & \multicolumn{2}{|c|}{ ZW-Overijssel } & \multicolumn{2}{|c|}{ Twente } & \multicolumn{2}{|c|}{ Totaal } \\
\hline & 1991 & 2001 & 1991 & 2001 & 1991 & 2001 & 1991 & 2001 \\
\hline Groningen & 0,6 & 0,4 & & & & 0,0 & 0,2 & 0,1 \\
\hline Friesland & 0,2 & 1,1 & & 0,3 & & 0,1 & 0,1 & 0,4 \\
\hline Drenthe & 6,0 & 3,7 & & 0,6 & 0,3 & 0,3 & 2,1 & 1,4 \\
\hline Overijssel & 82,4 & 83,5 & 74,6 & 74,1 & 95,3 & 93,0 & 88,1 & 87,6 \\
\hline Flevoland & 1,5 & 2,9 & & & 0,5 & 0,2 & 0,8 & 1,0 \\
\hline Gelderland & 4,8 & 5,1 & 14,0 & 19,9 & 2,1 & 4,5 & 4,7 & 6,7 \\
\hline Utrecht & 1,8 & 1,9 & 2,2 & 1,3 & 0,2 & 0,8 & 1,0 & 1,2 \\
\hline Noord-Holland & 0,9 & 0,8 & & 2,2 & 0,9 & 0,3 & 0,8 & 0,7 \\
\hline Zuid-Holland & 1,7 & 0,6 & 9,3 & & 0,1 & 0,5 & 2,0 & 0,5 \\
\hline \multicolumn{9}{|l|}{ Zeeland } \\
\hline Noord-Brabant & & & & 1,2 & 0,5 & 0,3 & 0,3 & 0,3 \\
\hline Limburg & & & & 0,3 & & & & 0,0 \\
\hline Totaal & 100 & 100 & 100 & 100 & 100 & 100 & 100 & 100 \\
\hline \multicolumn{9}{|c|}{ Uitsplitsing Overijssel } \\
\hline Noord-Overijssel & 79,9 & 79,3 & 5,8 & 10,9 & 3,1 & 2,0 & 27,8 & 26,5 \\
\hline Zuidwest-Overijssel & 0,7 & 1,9 & 61,0 & 60,2 & 0,7 & 1,3 & 9,8 & 9,3 \\
\hline Twente & 2,7 & 2,3 & 7,8 & 3,0 & 91,9 & 89,7 & 50,9 & 51,7 \\
\hline
\end{tabular}

Bewoners uit Overijssel blijken dus steeds verder te reizen naar hun werk, maar omgekeerd komen de mensen die in de provincie werken ook steeds van verder. Figuur 7.5 laat dit zien. Ook hier zien we dat steeds minder werkenden in de provincie binnen een straal van 10 kilometer wonen, terwijl steeds meer werkenden in een straal van 10-50 kilometer van het werk wonen. Een gevolg van deze landelijke trend is dat steeds meer mensen in een andere provincie wonen dan dat ze werken. Tabel 7.3 geeft voor Overijssel een beeld van de mobiliteit tussen de provincies. De tabel laat zien in welke provincies (en COROP-gebieden binnen de provincie) de bewoners van Overijssel werken. De afname van het aantal mensen dat buiten Overijssel werkt, blijkt maar betrekkelijk gering te zijn. Voor Overijssel als 
geheel is dit gedaald van 88,1 naar $87,6 \%$. In 1991 werkte dus $11,9 \%$ van de werkenden uit Overijssel buiten de provincie. In 2001 was dat 12,4 \%. Er zijn twee belangrijke oorzaken waarom ondanks de stijging van de reisafstanden toch maar zo'n kleine toename heeft plaatsgevonden van het percentage werkenden uit Overijssel dat buiten de provincie werkt.

Figuur 7.5

Verdeling van afstanden in woon-werkverkeer, Overijssel en Nederland, 1991 en 2001

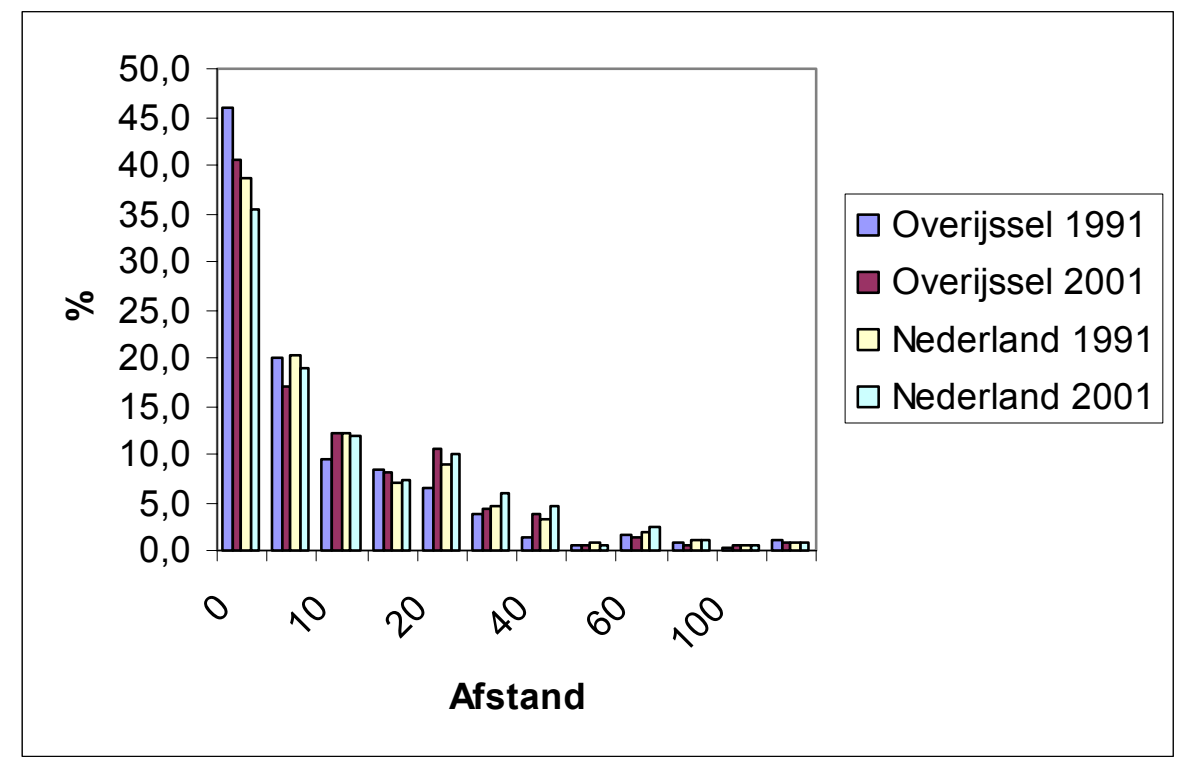

Bron: CBS

In de eerste plaats blijkt er een landelijke trend te zijn, waarbij mensen gemiddeld genomen steeds dichter bij de Randstad gaan werken en omgekeerd mensen die in de Randstad of de ringen daar omheen werken steeds verder van de Randstad af gaan wonen. De reden hiervoor is dat de Randstad nog steeds een sterkere economische ontwikkeling doormaakt dan de rest van Nederland. Met name hoger opgeleiden vinden daardoor steeds vaker werk in de Randstad. Werken in de Randstad wordt ook beter beloond dan elders. De consequentie is echter dat met de toenemende werkgelegenheid en hogere lonen ook de huizenprijzen stijgen. Mensen gaan daarom op zoek naar goedkopere huisvesting buiten de Randstad. Als gevolg daarvan stijgen de huizenprijzen in de randen rondom de Randstad, waardoor de mensen die daar werken weer de neiging krijgen nog iets verder weg te gaan wonen.

Voor Overijssel betekent dit dat mensen steeds minder vaak in Drenthe gaan werken en juist steeds vaker werk vinden in Gelderland en Utrecht. Doordat deze twee ontwikkelingen tegen elkaar in gaan is de totale groei in de grensoverschrijdende mobiliteit betrekkelijk gering.

Daarnaast blijkt ook Zwolle de afgelopen tien jaar een sterke aantrekkingskracht te hebben gehad. Bewoners uit Noord-Overijssel zijn per saldo vaker in de eigen regio 
blijven werken. Er is weliswaar een lichte groei van het aantal werkenden uit deze regio dat in Flevoland of Gelderland gaat werken, maar de afname van het aantal werkenden dat naar Drenthe gaat is veel groter. Ook blijkt er een sterke toename te zijn geweest van het aantal werkenden dat van Zuidwest-Overijssel naar NoordOverijssel gaat. Het gaat hierbij vrijwel altijd om werk in Zwolle.

Tabel 7.4

Herkomst van werkenden in Overijssel, 1991 en 2001, percentage van werkenden in Overijssel

\begin{tabular}{|c|c|c|c|c|c|c|c|c|}
\hline & \multicolumn{2}{|c|}{$\begin{array}{l}\text { Noord- } \\
\text { Overijssel }\end{array}$} & \multicolumn{2}{|c|}{$\begin{array}{l}\text { Zuidwest- } \\
\text { Overijssel }\end{array}$} & \multicolumn{2}{|c|}{ Twente } & \multicolumn{2}{|c|}{$\begin{array}{l}\text { Overijssel } \\
\text { totaal }\end{array}$} \\
\hline & 1991 & 2001 & 1991 & 2001 & 1991 & 2001 & 1991 & 2001 \\
\hline Groningen & 0,4 & 0,9 & & & & 0,1 & 0,1 & 0,3 \\
\hline Friesland & 1,9 & 2,2 & 0,5 & 0,5 & & 0,1 & 0,7 & 0,9 \\
\hline Drenthe & 4,0 & 6,9 & 1,4 & & 0,3 & 0,1 & 1,6 & 2,4 \\
\hline Overijssel & 87,0 & 79,1 & 78,2 & 80,6 & 95,0 & 96,0 & 90,1 & 88,5 \\
\hline Flevoland & 1,2 & 2,4 & 1,8 & 0,2 & & 0,1 & 0,6 & 0,9 \\
\hline Gelderland & 4,2 & 6,8 & 15,9 & 17,0 & 2,6 & 2,8 & 4,9 & 5,8 \\
\hline Utrecht & 0,6 & 0,3 & 1,2 & 0,2 & 0,5 & 0,1 & 0,6 & 0,2 \\
\hline Noord-Holland & 0,2 & 0,1 & & 1,1 & 0,8 & 0,2 & 0,5 & 0,3 \\
\hline Zuid-Holland & 0,5 & 0,8 & 0,9 & & 0,6 & 0,3 & 0,6 & 0,4 \\
\hline \multicolumn{9}{|l|}{ Zeeland } \\
\hline Noord-Brabant & & 0,3 & & 0,4 & 0,3 & 0,1 & 0,1 & 0,2 \\
\hline \multicolumn{9}{|l|}{ Limburg } \\
\hline Totaal & 100 & 100 & 100 & 100 & 100 & 100 & 100 & 100 \\
\hline \multicolumn{9}{|c|}{ Uitsplitsing Overijssel } \\
\hline Noord-Overijssel & 79,2 & 71,4 & 1,7 & 4,9 & 1,6 & 1,3 & 26,9 & 25,5 \\
\hline Zuidwest-Overijssel & 2,7 & 4,4 & 72,5 & 69,5 & 2,2 & 0,7 & 11,5 & 10,0 \\
\hline Twente & 5,1 & 3,4 & 2,8 & 6,1 & 91,6 & 94,0 & 51,8 & 53,0 \\
\hline
\end{tabular}

Bron: CBS

Tabel 7.4 geeft het spiegelbeeld van deze ontwikkeling, namelijk de herkomst van werkenden die in de provincie werken. Hier valt met name op de sterke daling van het percentage werkenden in Noord-Overijssel dat in Overijssel woont. In 1991 kwam nog $87 \%$ van de werkenden in deze regio uit de eigen provincie. In 2001 was dit nog maar $79,1 \%$.

Tabel 7.5 splitst de groep bewoners uit Overijssel die buiten de provincie werkt uit naar geslacht en opleidingsniveau. Over het algemeen is de provinciegrensoverschrijdende mobiliteit groter bij mannen dan bij vrouwen en neemt deze toe met het opleidingsniveau. De tabel laat zien dat in Overijssel inderdaad meer mannen dan vrouwen buiten de provincie werken. In 1991 blijkt het percentage mannen met alleen basisschool of met een MBO-diploma dat buiten de provincie werkt echter opmerkelijk hoog te zijn. 
Tabel 7.5

Pendelaars vanuit Overijssel, naar opleidingsniveau, 1991 en 2001, percentage van werkenden, wonend in Overijssel en werkend elders

\begin{tabular}{lcr}
\hline Mannen & 1991 & 2001 \\
\hline Basisschool & 21,8 & 9,2 \\
VMBO & 15,6 & 15,5 \\
MBO & 20,2 & 14,3 \\
HBO of WO & 11,6 & 19,7 \\
Totaal & 16,7 & 15,5 \\
\hline & & \\
\hline Vrouwen & 1991 & 2001 \\
\hline Basisschool & & 5,8 \\
VMBO & & 4,4 \\
MBO & 2,1 & 7,6 \\
HBO of WO & 4,4 & 11,0 \\
Totaal & 7,1 & 7,4 \\
\hline Bron: CBS & 3,9 &
\end{tabular}

Tabel 7.6

Pendelaars naar Overijssel, naar opleidingsniveau, 1991 en 2001, percentage van werkenden in Overijssel, wonend elders

\begin{tabular}{lrr}
\hline Mannen & 1991 & 2001 \\
\hline Basisschool & 12,2 & 15,9 \\
VMBO & 11,6 & 12,8 \\
MBO & 13,0 & 10,6 \\
HBO of WO & 7,3 & 19,3 \\
Totaal & 12,1 & 13,5 \\
\hline & & 2001 \\
\hline Vrouwen & 1991 & 6,6 \\
\hline Basisschool & & 5,3 \\
VMBO & 15,9 & 7,5 \\
MBO & 2,4 & 12,7 \\
HBO of WO & 7,9 & 8,3 \\
Totaal & 9,0 & 6,2 \\
\hline Bron: CBS & & \\
\hline
\end{tabular}

Maar liefst 21,8 \% van alle ongediplomeerden en 20,2 \% van de MBO'ers werkte in 1991 buiten Overijssel. Het ging hierbij met name om mannen uit ZuidwestOverijssel die in Gelderland werkten. In 2001 blijken deze percentages behoorlijk te 
zijn afgenomen en is daarentegen het percentage hoog opgeleiden mannen dat buiten de provincie werkt van 11,6 naar 19,7 \% behoorlijk gestegen. Bij de vrouwen blijkt op alle opleidingsniveaus het percentage werkenden dat buiten de provincie werkt te zijn gestegen.

Tabel 7.6 geeft een beeld van de verdeling naar geslacht en opleidingniveau van de werkenden in de provincie die buiten Overijssel wonen. De enige omvangrijke verschuiving die zich hier heeft voorgedaan is dat steeds meer hoger opgeleiden die in de provincie werken, buiten de provincie wonen. Bij mannen is dit percentage gestegen van 12,1 naar $13,5 \%$; bij vrouwen van 9,0 naar $12,7 \%$.

\subsection{Geografische mobiliteit en knelpunten in de personeelsvoorziening}

Naast het effect van geografische mobiliteit op de aanpassingen die schoolverlaters bereid zijn te accepteren om een baan te vinden, heeft geografische mobiliteit een effect op de verwachte arbeidsmarktsituatie in Overijssel en Nederland. Hiervoor kan gekeken worden naar de vereiste verandering in de inkomende pendelstromen, of in de instroom van schoolverlaters, om toekomstige knelpunten in de personeelsvoorziening voor werkgevers op te lossen. Door mensen van buiten Overijssel aan te trekken voor specifieke functies kunnen de knelpunten in de personeelsvoorziening verkleind worden. Anderzijds kunnen eventuele overschotten voor bepaalde beroepen in Overijssel worden gereduceerd als de inkomende pendelstroom afneemt. Daarnaast kan een grotere instroom van schoolverlaters en afgestudeerden op de Overijsselse arbeidsmarkt de personeelsschaarste voor Overijsselse werkgevers verlichten ten koste van werkgevers in andere provincies, of kunnen schoolverlaters hun perspectief op de arbeidsmarkt verbeteren door zich aan te bieden in andere provincies waar de schaarste aan personeel groter is. Hieronder worden de verwachte toekomstige tekorten per beroepsklasse in verband gebracht met de inkomende pendelstroom en de instroom van schoolverlaters en afgestudeerden op de Overijsselse arbeidsmarkt.

Tabel 7.7 laat zien dat het aantal inkomende pendelaars voor de Pedagogische beroepen in totaliteit met $155 \%$ moet toenemen om de toekomstige knelpunten in de personeelsvoorziening in deze beroepsklasse op de Overijsselse arbeidsmarkt op te lossen. Hetzelfde wordt bereikt indien de instroom van schoolverlaters met $88 \%$ toeneemt. Hieruit kan geconcludeerd worden dat de knelpunten in de personeelsvoorziening slechts in zeer beperkte mate verlicht kunnen worden door veranderingen in het arbeidsaanbod te bewerkstelligen, temeer omdat voor de Pedagogische beroepen de knelpunten in de rest van Nederland nog groter zijn (zie paragraaf 4.3). Ook voor de Openbare orde- en veiligheidsberoepen zijn de knelpunten in de rest van Nederland groter dan in Overijssel, waardoor een eventuele toename van de mobiliteit juist in de andere (voor Overijssel ongunstige) richting zou kunnen werken. Hierdoor zouden de knelpunten in de personeelsvoorziening voor werkgevers op de Overijsselse arbeidsmarkt juist vergroot worden. 
Tabel 7.7

Vereiste verandering van pendelstromen en van arbeidsmarktinstroom schoolverlaters (in procenten van de prognose tot 2008)

\begin{tabular}{lcc}
\hline & \multicolumn{2}{c}{ Vereiste verandering } \\
Beroepsklassen & $\begin{array}{c}\text { Inkomende } \\
\text { pendelaars }\end{array}$ & $\begin{array}{c}\text { Instroom van } \\
\text { schoolverlaters }\end{array}$ \\
& $\%$ & $\%$ \\
\hline Pedagogische beroepen & 155 & 88 \\
Culturele beroepen & - & - \\
Agrarische beroepen & - & - \\
Technische en industrieberoepen & -9 & -36 \\
Transportberoepen & -96 & 38 \\
Medische en paramedische beroepen & 69 & -22 \\
Economisch-administratieve beroepen & -36 & 34 \\
Informaticaberoepen & 62 & -23 \\
Sociaal-culturele beroepen & -27 & -7 \\
Verzorgende en dienstverlenende beroepen & -30 & 33 \\
Openbare orde- en veiligheidsberoepen & 131 & \\
& & \\
\hline$-:$ geen betrouwbare gegevens beschikbaar & & \\
Bron: ROA/CBS & &
\end{tabular}

Uit tabel 7.7 blijkt dat de vereiste procentuele verandering van het aantal inkomende pendelaars aanmerkelijk groter is dan dezelfde verandering in de instroom van schoolverlaters. Dit komt doordat Overijssel gekenmerkt kan worden als een provincie met relatief weinig inkomende pendelaars ten opzichte van de instroom van schoolverlaters. Het verkleinen van de knelpunten in de personeelsvoorziening voor werkgevers vereist dan een relatief grote stijging of daling in het aantal pendelaars. Voor de Technische en industrieberoepen geldt dat een daling van het arbeidsaanbod van inkomende pendelaars of schoolverlaters van gemiddeld $6 \%$ leidt tot het oplossen van de knelpunten in de personeelsvoorziening in Overijssel. Dit is een aantrekkelijke optie omdat er slechts een relatief kleine verandering in het regionale arbeidsaanbod in Overijssel voor nodig is. Voor de Sociaal-culturele beroepen is ook een daling in het Overijsselse arbeidsaanbod vereist om op dit arbeidsmarktsegment evenwicht op de Overijsselse arbeidsmarkt te bereiken, namelijk van $27 \%$ voor de inkomende pendelaars en $23 \%$ voor de instroom van schoolverlaters op de arbeidsmarkt. Dit is eveneens een aantrekkelijke optie, omdat de knelpunten voor deze beroepen in de rest van Nederland groter zijn. Hetzelfde speelt, in mindere mate, ook voor de Economisch-administratieve beroepen.

\subsection{Conclusies}

Bewoners uit Overijssel blijken steeds verder te reizen naar hun werk. Ook in Overijssel werkenden die in andere provincies wonen leggen grotere afstanden af om op hun werkplek te komen. Veelal wordt gedacht dat de toegenomen congestie een grote invloed heeft op de reistijden. Het effect hiervan op de reistijden in 
Overijssel blijkt echter zeer gering te zijn. De reistijden nemen immers niet significant toe door de langere afstand of door een verhoogde congestie.

De inpassing van Overijsselse schoolverlaters in het arbeidsproces is doorgaans redelijk gunstig. Vanuit de plaats van de school gezien leggen Overijsselse schoolverlaters gemiddeld een afstand van 39 kilometer af om een baan te vinden en zijn daarmee relatief mobieler dan de gemiddelde schoolverlater (28 kilometer). Dit heeft natuurlijk ook met de regionale spreiding van het onderwijs te maken, en de grotere afstanden in de provincie. De inpassing in het arbeidsproces verloopt voor de Overijsselse schoolverlaters doorgaans beter dan gemiddeld. Een hoger percentage vindt een baan die past bij hun studie of opleidingsrichting. Ook hebben zij in hogere mate een vast contract vergeleken met het Nederlandse gemiddelde.

Knelpunten in de personeelsvoorziening kunnen slechts in zeer beperkte mate verlicht worden door pendel of verhuizing. Terwijl enige aanpassing langs deze weg zeker mogelijk is, moet evenwel het gros van de aanpassingen via substitutie vanuit andere opleidingen (of beroepen) komen of via een aanpassing in de opleidingskeuzes van leerlingen en studenten. 


\section{Verklarende woordenlijst ${ }^{21}$}

\section{Arbeidsmarktinstroom van schoolverlaters}

Het aanbod van nieuwe arbeidskrachten op de arbeidsmarkt, zoals deze is bepaald door de verwachte uitstroom van schoolverlaters uit het initiële dagonderwijs inclusief de schoolverlaters van de beroepsbegeleidende leerweg (het voormalige leerlingwezen) - , de schoolverlaters van het deeltijdonderwijs, het niet-reguliere voltijdonderwijs en de beroepsgerichte volwasseneneducatie. Voor deze groep nieuwe arbeidskrachten wordt in dit rapport soms ook de alternatieve term 'nieuwkomers op de arbeidsmarkt' gebruikt.

\section{Arbeidsmarktkrapte}

Het begrip arbeidsmarktkrapte dat in deze rapportage gehanteerd wordt, is gedefinieerd als de verhouding tussen het aantal openstaande vacatures en het aantal niet-werkende werkzoekenden in bemiddelingsfase 1 per arbeidsmarktsegment. Wanneer de indicator voor de arbeidsmarktkrapte kleiner is dan één, is er sprake van een aanbodoverschot op het betreffende segment. Wanneer de indicator voor de arbeidsmarktkrapte groter is dan één, is er sprake van een tekort aan nietwerkende werkzoekenden in het betreffende segment. Dit tekort kan twee oorzaken hebben: wanneer het aanbod getalsmatig tekortschiet is er sprake van een kwantitatief probleem. Wanneer het probleem vooral gelegen is in het feit dat het aantal niet-werkende werkzoekenden in fase 1 als percentage van het totaal aantal niet-werkende werkzoekenden laag is, is dit tekort vooral een kwalitatief aansluitingsprobleem.

\section{Baanopeningen}

De baanopeningen representeren de totale vraag naar nieuwkomers op de arbeidsmarkt, zoals deze is bepaald door de werkgelegenheidsgroei (positieve uitbreidingsvraag) en de (netto) vervangingsvraag. Bij het vaststellen van het aantal baanopeningen wordt ermee rekening gehouden dat het aannemen van schoolverlaters door bedrijven en instellingen ('de vraag naar schoolverlaters') op nagenoeg hetzelfde niveau blijft ondanks een eventuele werkgelegenheidskrimp vanwege de extra uitstroom van ouderen. Een werkgelegenheidskrimp voor een opleidingstype of beroepsgroep gaat derhalve nauwelijks ten koste van het aantal baanopeningen in een opleidingstype of beroepsgroep.

\section{Bedrijfssector}

Alle voorkomende bedrijven zijn ingedeeld in een aantal clusters. De in deze rapportage gepresenteerde informatie is - met uitzondering van de totale werkgelegenheid - verbijzonderd naar 13 bedrijfssectoren. Deze komen overeen met de

21. De definities van begrippen sluiten zoveel aan bij de definities die in de landelijke rapportage worden gebruikt. Zie voor een verdere toelichting op de gehanteerde definities F. Cörvers et al. (2004), Methodiek arbeidsmarktprognoses en -indicatoren 2003-2008, ROA-W-2004/2, Maastricht. 
door het CPB gehanteerde bedrijfssectorindeling (zie Bijlage B). Verder wordt er in RAMING Digitaal waar mogelijk onderscheid gemaakt tussen 34 bedrijfssectoren.

\section{Bemiddelingsfase}

Het begrip bemiddelingsfase dat in deze rapportage wordt gehanteerd, is gebaseerd op de indeling van werkzoekenden zoals die door het Centrum voor Werk en Inkomen (CWI) wordt gehanteerd. Een hogere bemiddelingsfase impliceert een grotere afstand tot de arbeidsmarkt:

- $\quad$ Fase 1: De werkzoekende voor wie arbeidsmarktinstrumenten beschikbaar zijn gericht op directe bemiddeling of terugkeer naar de arbeidsmarkt.

- $\quad$ Fase 2: De werkzoekende voor wie arbeidsmarktinstrumenten beschikbaar zijn gericht op een zodanige verbetering van de kans op werk, dat hij/zij binnen een tijdsbestek van maximaal een jaar als werkzoekende bemiddelbaar is op de arbeidsmarkt.

- $\quad$ Fase 3: De werkzoekende voor wie arbeidsmarktinstrumenten beschikbaar zijn gericht op een zodanige verbetering van de kans op werk, dat hij/zij binnen een tijdsbestek van meer dan een jaar als werkzoekende bemiddelbaar is op de arbeidsmarkt.

- Fase 4: De werkzoekende die tengevolge van zware persoonlijke werkbelemmeringen is aangewezen op hulp en zorg die gericht is op een zodanige verbetering van zijn/haar eigen positie dat eerst op termijn arbeidsmarktinstrumenten inzetbaar zijn gericht op de verbetering van zijn/haar kans op werk.

\section{Beroepsgroep, Beroepsklasse, Beroepssegment}

Alle voorkomende beroepen zijn ingedeeld in een aantal clusters. In deze rapportage en de bijbehorende RAMING Digitaal wordt afwisselend gebruik gemaakt van de indeling in 127 beroepsgroepen, 11 beroepsklassen en 43 beroepssegmenten (zie Bijlage B).

\section{Conjunctuurgevoeligheid}

De conjunctuurgevoeligheid van de werkgelegenheid heeft betrekking op de mate waarin de werkgelegenheid voor arbeidskrachten met een bepaalde opleidingsachtergrond of werkzaam in een bepaalde beroepsgroep gevoelig is voor veranderingen van de economische situatie. Deze indicator geeft daarmee de mate van werkzekerheid aan. De conjunctuurgevoeligheid wordt bepaald door de sectorale werkgelegenheidsfluctuaties in het verleden te relateren aan de mate waarin een opleidingstype of een beroepsgroep momenteel in de verschillende bedrijfssectoren is vertegenwoordigd. Hierbij wordt rekening gehouden met het feit dat niet ieder opleidingstype en elke beroepsgroep even sterk meefluctueren met de werkgelegenheidsschommelingen van de bedrijfssector.

\section{Deeltijdarbeid}

Deeltijdarbeid betreft personen die hoogstens 32 uur maar minstens 12 uur per week werkzaam zijn. 


\section{Eigen vakrichting}

Een indicatie van de mate waarin arbeidskrachten werkzaam zijn in een functie die niet goed aansluit bij de gevolge opleidingsrichting. De mate waarin schoolverlaters buiten de eigen vakrichting werkzaam zijn wordt in dit rapport vastgesteld door de schoolverlaters zelf te laten aangeven in hoeverre voor de door hen uitgeoefende functie de eigen of een verwante opleidingsrichting vereist is.

\section{Flexibel werk}

Van flexibel werk is sprake bij uitzendkrachten, oproepkrachten, invalkrachten, contracten zonder een vast aantal arbeidsuren en indien geen vast dienstverband is overeengekomen.

\section{Opleidingscategorie, Opleidingstype}

Alle voorkomende opleidingen zijn samengevoegd tot een aantal clusters. In de prognosemethodiek en in de bij dit rapport verschenen RAMING Digitaal wordt voornamelijk uitgegaan van 113 opleidingstypen. In het rapport wordt in de meeste gevallen een indeling naar 17 opleidingscategorieën gehanteerd (zie Bijlage B).

\section{Potentiële beroepsbevolking}

De potentiële beroepsbevolking omvat de werkenden, de werklozen en de nietparticiperenden. ledereen die tussen de 15 en de 64 jaar oud is en geen voltijdopleiding volgt, wordt tot de potentiële beroepsbevolking gerekend. Als men meer dan 12 uur per week werkt, wordt men tot de werkzame beroepsbevolking gerekend. Werkt men niet of minder dan 12 uur, maar wil men wel minstens 12 uur per week betaalde arbeid verrichten, dan behoort men tot de werkloze beroepsbevolking. Werkt men niet of minder dan 12 uur, en is men niet op zoek naar betaalde arbeid voor minstens 12 uur per week, dan behoort men tot de nietparticiperende beroepsbevolking (de zgn. 'stille reserve').

\section{Substitutiemogelijkheden}

Deze wordt bepaald met behulp van een spreidingsindex die te interpreteren is als het genormeerd aantal opleidingstypen waaruit werkenden in deze beroepsgroep afkomstig zijn. De spreidingsindex geeft de mate aan waarin werkgevers voor een bepaalde beroepsgroep arbeidskrachten kunnen aantrekken met een uiteenlopende opleidingsachtergrond, zodat ze niet afhankelijk zijn van het arbeidsaanbod van één bepaald opleidingstype.

\section{Toekomstig arbeidsmarktperspectief}

Het toekomstig arbeidsmarktperspectief geeft de verhouding tussen aanbod en vraag in de prognoseperiode voor een opleidingstype weer. Als het arbeidsmarktperspectief slecht is, betekent dit dat er in het (de) komende ja(a)r(en) veel meer aanbod van nieuwkomers is dan er baanopeningen zijn. Hierdoor zal de arbeidsmarktpositie gaan verslechteren. Deze verslechtering kan een hogere werkloosheid betekenen, maar door aanpassingsprocessen op de arbeidsmarkt kan dit ook leiden tot het moeten aanvaarden van banen op een lager niveau, een lagere beloning en meer tijdelijke contracten. Omgekeerd zal een goed perspectief tot een grotere kans op werk, maar ook tot een verbeterde positie op andere punten leiden. Het toekomstig arbeids- 
marktperspectief per opleidingstype wordt bepaald door middel van de Indicator Toekomstige Arbeidsmarktsituatie (ITA), die is gedefinieerd als de verhouding tussen enerzijds de verwachte instroom van schoolverlaters en het aantal kortdurig werklozen (i.e. korter dan 1 jaar werkloos) en anderzijds de verwachte baanopeningen. Naarmate de waarde van de indicator hoger is, is het perspectief slechter. Een waarde rond de 1 duidt op een evenwichtssituatie. Merk overigens op dat een hogere ITA een slechtere (toekomstige) arbeidsmarktsituatie impliceert, terwijl een hogere arbeidsmarktkrapte een indicatie is voor een betere (huidige) arbeidsmarktpositie van een opleidingstype.

\section{Toekomstige knelpunten in de Personeelsvoorziening}

Als de toekomstige vraag naar werkenden met een bepaalde opleidingsachtergrond groter is dan het aanbod, kunnen knelpunten in de personeelsvoorziening verwacht worden. Vergelijkbaar met de Indicator Toekomstige Arbeidsmarktsituatie (ITA, zie hierboven) geeft de Indicator Toekomstige Knelpunten in de Personeelsvoorziening (ITKP) deze vraag-aanbod-spanning aan. Het verschil met de ITA is dat bij de ITKP de uitstroom van werkenden als gevolg van een krimpende werkgelegenheid is meegerekend in de vraag, omdat verwacht mag worden dat bij knelpunten in de personeelsvoorziening deze (gedwongen) uitstroom kan worden afgeremd of elders werk zou kunnen vinden. Naarmate de waarde van de indicator lager is, zijn de verwachte knelpunten groter. Een waarde rond de 1 duidt op een evenwichtssituatie.

\section{Toekomstige Knelpunten in de personeelsvoorziening naar Beroep}

Om inzicht te verschaffen hoe de aansluitingsproblematiek tussen onderwijs en arbeidsmarkt zijn weerslag heeft op de wervingsproblematiek in de verschillende beroepsgroepen, wordt gebruik gemaakt van de Indicator Toekomstige Knelpunten in de Personeelsvoorziening naar Beroepsgroep (ITKB). De ITKB geeft aan in welke mate het voor werkgevers mogelijk is om de gewenste personeelssamenstelling naar opleidingsachtergrond binnen beroepen te realiseren bij de voorspelde vraagaanbod-verhoudingen voor de verschillende opleidingstypen. De ITKB heeft een waarde tussen 0 en 1 . Naarmate de waarde van de indicator lager is, zijn de knelpunten in de personeelsvoorziening voor de betreffende beroepsgroep groter. Werkgevers zullen dan relatief veel moeite hebben nieuw personeel met de door hen gewenste opleidingsachtergrond te vinden. Wanneer de ITKB daarentegen bijna gelijk is aan 1, zullen werkgevers weinig moeite hebben de gewenste personeelssamenstelling binnen het beroep te realiseren. Voor die opleidingen die aandacht schenken aan de in dat beroep relevante kennis en vaardigheden, worden dan geringe knelpunten verwacht.

\section{Uitbreidingsvraag}

De uitbreidingsvraag is de vraag naar nieuwe arbeidskrachten die ontstaat door groei van de werkgelegenheid. Als er sprake is van een werkgelegenheidsdaling, is de uitbreidingsvraag negatief.

\section{Uitwijkmogelijkheden}

Dit is de mate waarin arbeidskrachten met een bepaalde opleidingsachtergrond terecht kunnen komen in andere beroepsgroepen op een aansluitend of hoger 
functieniveau. Deze maatstaf geeft daarmee aan in hoeverre arbeidskrachten afhankelijk zijn van de arbeidsmarktsituatie in een bepaald beroep. De uitwijkmogelijkheden worden bepaald met behulp van een spreidingsindex. Deze index geeft een indicatie van het aantal beroepsgroepen waarnaar men kan uitwijken.

\section{Vacature}

Openstaande vacatures die geregistreerd worden bij het CWI, en vervolgens worden opgehoogd op basis van vacaturecijfers van het CBS. Het begrip vacature is in RAMING Digitaal gebaseerd op de door het CBS gehanteerde definitie van een openstaande vacature, zijnde een arbeidsplaats waarvoor personeel wordt gezocht dat onmiddellijk of zo spoedig mogelijk geplaatst kan worden.

\section{Vervangingsvraag}

Vervangingsvraag is de vraag naar nieuwe arbeidskrachten die ontstaat doordat de arbeidsplaatsen van werkenden die met pensioen gaan, arbeidsongeschikt worden of zich (tijdelijk) terugtrekken van de arbeidsmarkt, opnieuw moeten worden opgevuld. De vervangingsvraag per beroepsgroep kan bovendien ontstaan door de beroepsmobiliteit. Verder kan een onderscheid worden gemaakt tussen de netto en de bruto vervangingsvraag. De netto vervangingsvraag heeft alleen betrekking op de vervangingsbehoefte voor zover deze opgevuld zou moeten worden door schoolverlaters die op de arbeidsmarkt instromen. De bruto vervangingsvraag is de totale uitstroom van werkenden die vervangen moeten worden. De bruto vervangingsvraag omvat dus ook de vervangingsvraag die zou kunnen worden opgevuld door herintreders en baanwisselaars. In het huidige rapport wordt alleen de netto vervangingsvraag gebruikt en gepresenteerd.

\section{Werkende}

Het aantal werkenden heeft betrekking op iedereen die ouder is dan 15 jaar en jonger is dan 65 jaar en minstens 12 uur per week werkt.

\section{Werkloosheid}

Werkloosheid wordt gedefinieerd op basis van de CBS-definitie van de werkloze beroepsbevolking. Tot de werkloze beroepsbevolking worden gerekend de personen die niet of minder dan 12 uur werken en die:

- werk hebben aanvaard waardoor ze ten minste 12 uur per week gaan werken, of;

- verklaren ten minste 12 uur per week te willen werken, daarvoor beschikbaar zijn en activiteiten ontplooien om werk voor ten minste 12 uur per week te vinden.

Het werkloosheidspercentage wordt normaal gesproken bepaald door het aantal werklozen te relateren aan de beroepsbevolking. In RAMING Digitaal is het aantal werklozen echter gedeeld door de potentiële bevolking (zie definitie in deze bijlage). Bovendien hanteert het Etil in de regiorapportages een werkloosheidspercentage dat is gebaseerd op het aantal werkzoekenden van het CWI (zie definitie in deze bijlage en regiorapportages van het Etil). 


\section{Werkzoekende}

Het begrip werkzoekende is in deze rapportage gedefinieerd als de het Centrum voor Werk en Inkomen (CWI) ingeschreven niet-werkende werkzoekenden, inclusief de categorie 'geen beroep op dienstverlening'. De werkzoekenden kunnen worden naar bemiddelingsfase (zie definitie in deze bijlage). 


\section{Statistische Bijlage \\ De Overijsselse arbeidsmarkt naar opleiding en beroep \\ 2003-2008}

ROA-R-2005/1B

S. Dijksman

B. Kriechel

\section{Researchcentrum voor Onderwijs en Arbeidsmarkt}

Faculteit der Economische Wetenschappen en Bedrijfskunde Universiteit Maastricht

Maastricht, februari 2005 
Niets uit deze uitgave mag worden verveelvoudigd en/of openbaar gemaakt door middel van druk, fotokopie, microfilm, of op welke wijze ook, zonder voorafgaande schriftelijke toestemming van de directeur van het Researchcentrum voor Onderwijs en Arbeidsmarkt. In geval van overname van het datamateriaal moet telkens als bron worden vermeld: "Researchcentrum voor Onderwijs en Arbeidsmarkt" of "ROA". Van publicaties waarin gebruik wordt gemaakt van gegevens uit dit rapport ontvangen wij gaarne een exemplaar.

Hoewel de grootst mogelijke zorg is besteed aan de inhoud van dit rapport, kan het ROA in generlei opzicht verantwoordelijkheid op zich nemen voor eventuele onvolledigheden of onjuistheden. 


\section{Inhoud}

Pagina

Voorwoord

1 De werkgelegenheidstructuur in Overijssel

Tabel 1.1 Aantal werkenden per bedrijfssector, Overijssel, gemiddelde 2001-2002

Tabel 1.2 Belangrijkste opleidingsniveaus van de werkenden per bedrijfssector, Overijssel, gemiddelde 2001-2002

Tabel 1.3 Percentage jongeren (15-29 jaar) per bedrijfssector, Overijssel, gemiddelde 2001-2002

Tabel 1.4 Percentage ouderen (50-64 jaar) per bedrijfssector, Overijssel, gemiddelde 2001-2002

Tabel 1.5 Percentage vrouwen per bedrijfssector, Overijssel, gemiddelde 2001-2002

Tabel 1.6 Percentage flexibel werk per bedrijfssector, Overijssel, gemiddelde 2001-2002

Tabel 1.7 Percentage deeltijdwerk per bedrijfssector, Overijssel, gemiddelde 2001-2002

Tabel 1.8 Percentage zelfstandigen per bedrijfssector, Overijssel, gemiddelde 2001-2002

Tabel 1.9 Aantal werkenden per beroepssegment, Overijssel, gemiddelde 2001-2002

Tabel 1.10 Percentage jongeren (15-29 jaar) per beroepssegment, Overijssel, gemiddelde 2001-2002

Tabel 1.11 Percentage ouderen (50-64 jaar) per beroepssegment, Overijssel, gemiddelde 2001-2002

Tabel 1.12 Percentage vrouwen per beroepssegment, Overijssel, gemiddelde 2001-2002

Tabel 1.13 Percentage flexibel werk per beroepssegment, Overijssel, gemid-

delde 2001-2002

Tabel 1.14 Percentage deeltijdwerk per beroepssegment, Overijssel, gemid-
delde 2001-2002 Percentage zelfstandigen per beroepssegment, Overijssel,

Tabel 1.15 Percentage zelfstandigen per beroepssegment, Overijssel,
gemiddelde 2001-2002

Tabel 1.16 Aantal werkenden per opleidingstype, Overijssel, gemiddelde 2001-2002

Tabel 1.17 Arbeidsmarktpositie potentiële beroepsbevolking naar opleidingstype, Overijssel, gemiddelde 2001-2002

Tabel 1.18 Percentage jongeren (15-29 jaar) per opleidingssector, Overijssel, gemiddelde 2001-2002

Tabel 1.19 Percentage ouderen (50-64) per opleidingssector, Overijssel, gemiddelde 2001-2002

Tabel 1.20 Percentage vrouwen per opleidingssector, Overijssel, gemiddelde 2001-2002

Tabel 1.21 Percentage flexibel werk per opleidingssector, Overijssel, gemiddelde 2001-2002

Tabel 1.22 Percentage deeltijdwerk per opleidingssector, Overijssel, gemiddelde 2001-2002

Tabel 1.23 Percentage zelfstandigen per opleidingssector, Overijssel, gemiddelde 2001-2002 
Tabel 2.1 Aantal leerlingen in het VMBO en MBO per opleidingstype, Overijssel, 2002 en 2003

Tabel 2.2 Percentage leerlingen (BBL) in het MBO per opleidingstype, Overijssel, 2002 en 2003

Tabel 2.3 Percentage vrouwelijke leerlingen in het VMBO en MBO per opleidingstype, Overijssel, 2002 en 2003

Tabel 2.4 Aantal gediplomeerden in het VMBO en MBO per opleidingstype, Overijssel, 2002 en 2003

Tabel 2.5 Percentage gediplomeerden (BBL) in het MBO per opleidingstype, Overijssel 2002 en 2003

Tabel 2.6 Percentage vrouwelijke gediplomeerden in het VMBO en MBO per opleidingstype, Overijssel, 2002 en 2003

Tabel 3.1 Openstaande vacatures per bedrijfssector, Overijssel, april 2004

Tabel 3.2 Openstaande vacatures per beroepssegment, Overijssel, april 2004

Tabel 3.3 Niet-werkende werkzoekenden per beroepssegment, Overijssel,

Tabel 3.4 Niet-werkende werkzoekenden per beroepssegment en bemiddelingsfase, Overijssel, april 2004

Tabel 3.5 Kenmerken niet-werkende werkzoekenden per beroepssegment, Overijssel, april 2004

Tabel 3.6 Discrepanties per bedrijfssector, Overijssel, april 2004

Tabel 3.7 Discrepanties per beroepssegment, Overijssel, april 2004

\section{De Overijsselse arbeidsmarkt tot 2008}

Tabel 4.1 Verwachte uitbreidingsvraag per bedrijfssector (als percentage van de werkgelegenheid), Overijssel, 2003-2008

Tabel 4.2 Verwachte uitbreidingsvraag per beroepsgroep (als percentage van de werkgelegenheid), Overijssel, 2003-2008 60

Tabel 4.3 Verwachte vervangingsvraag per beroepsgroep (als percentage van de werkgelegenheid), Overijssel, 2003-2008

Tabel 4.4 Verwachte baanopeningen per beroepsgroep (als percentage van de werkgelegenheid), Overijssel, 2003-2008

Tabel 4.5 Indicator Toekomstige knelpunten in de personeelsvoorziening per Beroep (ITKB) per beroepsgroep, Overijssel, 2003-2008 (alleen elementaire, lagere en middelbare beroepen)

Tabel 4.6 Verwachte uitbreidingsvraag per opleidingstype (als percentage van de werkgelegenheid), Overijssel, 2003-2008

Tabel 4.7 Verwachte vervangingsvraag per opleidingstype (als percentage van de werkgelegenheid), Overijssel, 2003-2008 73

Tabel 4.8 Verwachte baanopeningen per opleidingstype (als percentage van de werkgelegenheid), Overijssel, 2003-2008

Tabel 4.9 Verwachte arbeidsmarktinstroom van schoolverlaters per opleidings-type (als percentage van de werkgelegenheid), Overijssel, 2003-2008 (alleen lagere en middelbare opleidingen) 
Tabel 4.10 Indicator Toekomstperspectieven op de arbeidsmarkt voor schoolverlaters (ITA) en Indicator Toekomstige Knelpunten in de Personeelsvoorziening (ITKP) per opleidingstype, Overijssel, 2003-2008 (alleen lagere en middelbare opleidingen)

Tabel 4.11 Conjunctuurgevoeligheid per opleidingstype

Tabel 4.12 Uitwijkmogelijkheden naar verschillende beroepsgroepen per opleidingstype, Overijssel, gemiddelde 2001-2002

Tabel 4.13 Substitutiemogelijkheden tussen mensen met uiteenlopende opleidingsachtergronden per beroepsgroep, Overijssel, gemiddelde 2001-2002

\section{$5 \quad$ Classificaties}

Overzicht van opleidingstypen

Beroepsgroepen, volgorde ROA

Beroepsgroepen, volgens SBC '92

98

Beknopte Bedrijfsclassificatie SBI '93

105

Uitgebreide Bedrijfsclassificatie SBI '93 



\section{Voorwoord}

Deze Statistische Bijlage bij het rapport De Overijsselse arbeidsmarkt 2003-2008 geeft een systematisch overzicht van de verwachte arbeidsmarktontwikkelingen en de actuele arbeidsmarktgegevens die ten grondslag liggen aan het hoofdrapport. Op basis van de in het kader van het project Regionale ArbeidsMarkT Informatiesysteem Overijssel (RATIO) gegenereerde en verzamelde kwantitatieve informatie wordt een zo volledig mogelijk beeld gegeven, verbijzonderd naar 13 bedrijfssectoren, 127 beroepsgroepen en 113 opleidingstypen. Het doel van RATIO is het ontwikkelen en actualiseren van een informatiesysteem dat een breed overzicht geeft van de huidige arbeidsmarktsituatie en de toekomstige arbeidsmarktontwikkelingen in de provincie Overijssel en de twee onderscheiden RPA-rayons (Regionale Platforms Arbeidsmarkt) IJssel Vecht en Twente. Uit dit overzicht komen de huidige en toekomstige discrepanties naar beroep en opleiding naar voren. Op basis van het informatiesysteem van RATIO kan door de provincie Overijssel en de verschillende arbeidsmarktparticipanten in de provincie beleid geformuleerd en uitgevoerd worden. Bovendien kan de informatie gebruikt worden in het kader van de studie- en beroepskeuzevoorlichting, bijvoorbeeld voor jongeren die hun opleidingskeuze moeten bepalen. Het hoofdrapport De Overijsselse arbeidsmarkt 2003-2008 geeft het kader aan waarin de tabellen in deze Statistische Bijlage moeten worden geplaatst. Voor de gebruikte terminologie wordt verwezen naar de Verklarende woordenlijst achter in het hoofdrapport.

Deze Statistische Bijlage bestaat uit vijf delen. In de eerste drie delen staat de actuele arbeidsmarktsituatie centraal. In het eerste deel wordt een beeld geschetst van de werkgelegenheidsstructuur in de provincie Overijssel. Er wordt achtereenvolgens informatie gepresenteerd over de persoons- en functiekenmerken van de werkzame beroepsbevolking in Overijssel naar bedrijfssector, beroepsgroep en opleidingstype (dan wel beroepssegment en opleidingssector). Hierbij wordt telkens ook een vergelijking gemaakt met het landelijke beeld. De arbeidsmarktgegevens met betrekking tot de werkzame en niet-werkzame bevolking in het eerste deel zijn afkomstig uit de Enquête Beroepsbevolking (EBB) van het Centraal Bureau voor de Statistiek (CBS).

Het tweede deel bevat gegevens over het aantal leerlingen en gediplomeerden in het voorbereidend en middelbaar beroepsonderwijs (VMBO en $\mathrm{MBO}$ ). Hiermee wordt een indruk verkregen van het potentiële actuele en toekomstige aanbod van schoolverlaters op de Overijsselse arbeidsmarkt. Van belang is echter op te merken dat een aanzienlijk deel van de schoolverlaters doorstroomt binnen de beroepskolom. De gegevens hebben betrekking op de kalenderjaren 2002 en 2003 en zijn uitgesplitst naar opleidingstype en geslacht. Bovendien zijn de aantallen leerlingen en gediplomeerden van het MBO uitgesplitst naar beroepsbegeleidende leerweg (BBL). De gegevens zijn gebaseerd op de aanlevering door de Overijsselse ROC's en $A O C$ in het kader van de Bekostigingstellingen van de Centrale Financiën Instellingen (Cfi) voor het Ministerie van OCenW en de Landbouwtellingen ${ }^{1}$ van STOAS voor het Ministerie van LNV.

In het derde deel staan de actuele discrepanties tussen vraag en aanbod op de arbeidsmarkt, alsmede de actuele arbeidsmarktsituatie van de MBO-schoolverlaters centraal. In dit derde deel wordt eerst aandacht geschonken aan de openstaande vacatures naar bedrijfssector en beroepssegment. Hierbij wordt niet alleen het aantal openstaande vacatures weergeven, maar ook de vacaturegraad en het percentage langdurig openstaande vacatures. Tevens wordt er informatie gepresenteerd over het aantal niet-werkende werkzoekenden en hun achtergrondkenmerken naar geslacht, leeftijd, zoekduur en bemiddelbaarheid. Verder wordt er informatie gegeven over de verhouding tussen vacatures en werkzoekenden (fase 1 en fase 2/3) per bedrijfssector en beroepssegment. In aansluiting hierop worden de aantallen openstaande vacatures en niet-werkende werkzoekenden met elkaar geconfronteerd. Dit maakt het mogelijk

1. Opgemerkt dient te worden dat de gegevens van de gediplomeerden in de landbouwopleidingen van het VMBO en het MBO in het kalenderjaar 2001 alleen betrekking hebben op de gediplomeerden die niet in het onderwijs doorstromen. 
de kwantitatieve en kwalitatieve discrepanties op de Overijsselse arbeidsmarkt in beeld te brengen. Hiervoor worden twee indicatoren gepresenteerd. De indicator voor de arbeidsmarktkrapte naar bedrijfssector, beroepssegment of opleidingssector geeft de verhouding weer tussen het aantal openstaande vacatures en het aantal direct bemiddelbare werkzoekenden (fase 1). Wanneer de indicator voor de arbeidsmarktkrapte groter is dan één, is er sprake van een tekort. Wanneer de indicator daarentegen kleiner is dan één, dan is er sprake van (enige) ruimte op het desbetreffende arbeidsmarktsegment. De knelpuntindicator geeft aan in hoeverre een tekort aan direct-inzetbaar aanbod een kwantitatief of een kwalitatief karakter heeft. De indicator geeft de verhouding weer tussen enerzijds het aantal openstaande vacatures dat niet door direct inzetbare werkzoekenden kan worden opgevuld en anderzijds het aantal niet-werkende werkzoekenden met een wat grotere afstand tot de arbeidsmarkt. Naarmate deze verhouding groter wordt, heeft het tekort een meer kwantitatief karakter. Het aantal niet-werkende werkzoekenden schiet in dit geval eenvoudigweg tekort om aan de openstaande vraag te voldoen. De gegevens over vacatures en niet-werkende werkzoekenden zijn afkomstig van het Centrum voor Werk en Inkomen (CWI Oost-Nederland). De informatie per opleidingssector kon door omstandigheden niet door het Centrum voor Werk en Inkomen worden samengesteld. Het derde deel eindigt met informatie over de actuele arbeidsmarktpositie van MBO-schoolverlaters op de Overijsselse arbeidsmarkt en is gebaseerd op gegevens uit het Schoolverlaters Informatie Systeem (SIS) van het ROA. Deze informatie geeft niet alleen de werkloosheid weer, maar ook bijvoorbeeld de mate waarin schoolverlaters onder hun niveau of buiten hun vakrichting werken. Daarbij wordt per opleidingssector een vergelijking gemaakt met de landelijke arbeidsmarktpositie van MBO-schoolverlaters.

De in deel vier gepresenteerde tabellen geven een beeld van de te verwachten toekomstige ontwikkelingen op de Overijsselse arbeidsmarkt naar beroepsgroep en opleidingstype. In deel vier wordt een overzicht wordt gegeven van de prognoses voor de middellange termijn (de periode 2003-2008). De prognoses binnen RATIO zijn (deels) gebaseerd op de uitkomsten van het landelijke model waarvan de uitkomsten door het ROA zijn gepresenteerd in De arbeidsmarkt naar opleiding en beroep tot 2008 (ROA-R-2002/8). Het Etil heeft de prognoses voor de werkgelegenheidsgroei per bedrijfssector aan het ROA geleverd. Bij het samenstellen van deze prognoses door Etil is mede gebruik gemaakt van de op dit moment meest recente sectorprognoses uit het Centraal Economisch Plan van het Centraal Planbureau.

De gepresenteerde prognoses hebben zowel betrekking op de vraagzijde als op de aanbodzijde van de arbeidsmarkt. Aan de vraagzijde van de arbeidsmarkt wordt een onderscheid gemaakt tussen de uitbreidingsvraag en de vervangingsvraag, die tezamen de baanopeningen voor nieuwkomers op de arbeidsmarkt vormen. De Indicator Toekomstige Arbeidsmarktperspectieven (ITA) geeft de verhouding tussen vraag en aanbod per opleidingstype weer. Daarbij moet worden bedacht dat een aanbodoverschot van mensen met een bepaalde opleidingsachtergrond of beroep niet per se tot werkloosheid van de betrokkenen hoeft te leiden. Een gebrekkige aansluiting tussen vraag en aanbod kan zich ook manifesteren in een hogere kans op werk buiten het eigen vakgebied of beneden het gevolgde opleidingsniveau, een lagere beloning, een grotere kans op een tijdelijk contract, etc. De Indicator Toekomstige Knelpunten in de Personeelsvoorziening (ITKP) en de Indicator Toekomstige Knelpunten in de Personeelsvoorziening naar Beroep (ITKB) bezien de implicaties van de verhouding tussen vraag en aanbod vanuit het gezichtspunt van de werkgever. Ook hierbij moet bedacht worden dat een aanbodtekort niet per se tot openstaande vacatures hoeft te leiden, maar ook aanpassingsprocessen op gang kan brengen.

De prognoses voor de perspectieven en knelpunten naar beroepsgroep hebben alleen betrekking op de elementaire, lagere en middelbare beroepen, terwijl de prognoses voor de perspectieven en knelpunten naar opleidingstype alleen betrekking hebben op het Basisonderwijs, de VMBO-opleidingen en de opleidingen op MBO-niveau. Bij de hogere beroepen en opleidingen is de instroom op de arbeidsmarkt van afgestudeerden veel moeilijker aan één bepaalde regio of 
provincie toe te schrijven. Voor de hogere beroepen en opleidingen worden alleen prognoses voor de uitbreidings- en vervangingsvraag en de daaruit resulterende baanopeningen gepresenteerd.

In deel vijf is ook informatie opgenomen over de structurele positie van opleidingen op de arbeidsmarkt. Het betreft hier de conjunctuurgevoeligheid van de werkgelegenheid en de uitwijkmogelijkheden van de schoolverlaters op de arbeidsmarkt. Deze indicatoren hebben tot doel het perspectief in een breder kader te plaatsen. De prognoses van vraag en aanbod zijn uiteraard aan onzekerheid onderhevig. Bovendien zal een schoolverlater doorgaans een lange tijd op de arbeidsmarkt vertoeven. De structurele kenmerken beogen daarom een indicatie te geven van de risico's die men op een bepaald arbeidsmarktsegment loopt. Zo geeft de conjunctuurgevoeligheid aan in welke mate de werkgelegenheid voor het desbetreffende opleidingstype aan schommelingen onderhevig is, terwijl de uitwijkmogelijkheden aangeven in welke mate de werkenden afhankelijk zijn van de werkgelegenheidsontwikkelingen in één beroepsgroep of juist uit kunnen wijken naar meerdere beroepsgroepen.

In de meeste tabellen wordt ook een kwalitatieve typering gegeven van de gepresenteerde informatie. Dit maakt het mogelijk de informatie voor een bepaalde sector, beroepsgroep of opleiding snel te interpreteren. Bij de actuele arbeidsmarktinformatie wordt tevens een indicatie gegeven van de trend in de afgelopen jaren. Bij de informatie over beroepsgroepen, opleidingstypen en bedrijfssectoren gaat het hierbij om de ontwikkeling in de periode 1998-2002. De informatie over de trendmatige ontwikkeling heeft meestal betrekking op de ontwikkeling van het aandeel van de desbetreffende categorie. Alleen bij de tabellen 1.1, 1.9 en 1.16 gaat het om de ontwikkeling van het aantal werkenden.

Om de robuustheid van de informatie uit de EBB te vergroten, hebben de gepresenteerde gegevens telkens betrekking op het gemiddelde van de jaren 2001 en 2002. Om de herkenbaarheid van individuele respondenten te voorkomen, heeft het CBS de restrictie gesteld dat bij het publiceren van tweejaarlijkse gemiddelden alleen cijfers over categorieën mogen worden gepresenteerd die betrekking hebben op tenminste 2.500 personen, of op een randtotaal van tenminste 15.000 personen. In deel drie heeft het ROA, in het licht van de betrouwbaarheid van de informatie, de aantallen openstaande vacatures en niet-werkende werkzoekenden afgerond op tientallen. Bovendien is er een ondergrens van 10 gehanteerd. In de delen vier en vijf is een ondergrens van 2.000 personen gehanteerd. Wanneer er in een beroepsgroep of opleidingstype minder dan 2.000 mensen werkzaam zijn, worden alleen kwalitatieve typeringen van de verwachte ontwikkelingen gepresenteerd.

De informatie naar bedrijfssector is gebaseerd op de Standaard Bedrijfsindeling 1993 (SBI'93) van het CBS. De informatie naar beroepsgroep is gebaseerd op de Standaard Beroepsclassificatie 1992 (SBC'92) van het CBS. Hierbij is de 3-digitcode van het CBS gebruikt, waarbij code 471 is uitgesplitst in Bakkers en slagers en Procesoperators. Bovendien is bij de elementaire beroepen een uitsplitsing gemaakt naar zes beroepsgroepen. Tevens is afgeweken van de door het CBS gehanteerde namen. In plaats daarvan worden kortere beroepsnamen gebruikt. Voor de informatie naar opleidingstype is door het ROA een eigen classificatie ontwikkeld waarin opleidingen geclusterd zijn die in hoge mate hetzelfde beroependomein kennen. Deze classificatie is overigens wel gekoppeld aan de Standaard Onderwijs Indeling (SOI) van het CBS. Achter in deze Statistische Bijlage is een overzicht opgenomen van de gehanteerde classificaties. Meer informatie over deze classificaties is opgenomen in de ROA-classificatiegids 2002. 

1 De werkgelegenheidstructuur in Overijssel 

Tabel 1.1

Aantal werkenden per bedrijfssector, Overijssel, gemiddelde 2001-2002

\begin{tabular}{|c|c|c|c|}
\hline Bedrijfssector & Aantal & $\begin{array}{l}\text { Overijssel } \\
\text { t.o.v. } \\
\text { Nederland }\end{array}$ & $\begin{array}{l}\text { Trend } \\
1998-2002\end{array}$ \\
\hline Landbouw en visserij & 15.500 & gemiddeld & dalend \\
\hline $\begin{array}{l}\text { Tuinbouw } \\
\text { Veehouderij } \\
\text { Akkerbouw, bosbouw en visserij }\end{array}$ & $\begin{array}{r}- \\
12.500 \\
-\end{array}$ & $\begin{array}{l}\text { erg laag } \\
\text { hoog } \\
\text { gemiddeld }\end{array}$ & $\begin{array}{l}\text { constant } \\
\text { constant } \\
\text { sterk dalend }\end{array}$ \\
\hline Voeding & 12.500 & hoog & constant \\
\hline $\begin{array}{l}\text { Vlees- en visverwerking } \\
\text { Overige voedingsproducten } \\
\text { Drank en tabaksproducten }\end{array}$ & $\begin{array}{l}5.000 \\
6.500\end{array}$ & $\begin{array}{l}\text { erg hoog } \\
\text { gemiddeld } \\
\text { laag }\end{array}$ & $\begin{array}{l}\text { constant } \\
\text { constant } \\
\text { sterk dalend }\end{array}$ \\
\hline Chemie & 9.000 & gemiddeld & constant \\
\hline $\begin{array}{l}\text { Basischemie } \\
\text { Eindproducten chemie } \\
\text { Kunststofverwerking }\end{array}$ & $\begin{array}{r}- \\
- \\
6.000\end{array}$ & $\begin{array}{l}\text { erg laag } \\
\text { laag } \\
\text { erg hoog }\end{array}$ & $\begin{array}{l}\text { sterk dalend } \\
\text { sterk dalend } \\
\text { constant }\end{array}$ \\
\hline Metaal en elektrotechniek & 32.500 & hoog & constant \\
\hline $\begin{array}{l}\text { Basismetaal } \\
\text { Metaalproducten } \\
\text { Machine-industrie } \\
\text { Elektrotechniek } \\
\text { Transportmiddelen }\end{array}$ & $\begin{array}{l}9.500 \\
9.500 \\
9.000 \\
4.000\end{array}$ & $\begin{array}{l}\text { erg laag } \\
\text { hoog } \\
\text { hoog } \\
\text { hoog } \\
\text { gemiddeld }\end{array}$ & $\begin{array}{l}\text { sterk dalend } \\
\text { constant } \\
\text { dalend } \\
\text { constant } \\
\text { stijgend }\end{array}$ \\
\hline Overige industrie & 34.500 & erg hoog & constant \\
\hline $\begin{array}{l}\text { Textiel } \\
\text { Hout- en bouwmaterialen } \\
\text { Papier } \\
\text { Grafische industrie }\end{array}$ & $\begin{array}{r}6.500 \\
18.000 \\
- \\
7.500\end{array}$ & $\begin{array}{l}\text { erg hoog } \\
\text { hoog } \\
\text { hoog } \\
\text { gemiddeld }\end{array}$ & $\begin{array}{l}\text { constant } \\
\text { constant } \\
\text { sterk stijgend } \\
\text { stijgend }\end{array}$ \\
\hline Energie & 4.000 & gemiddeld & constant \\
\hline Energie & 4.000 & gemiddeld & constant \\
\hline Bouw en onroerend goed & 44.000 & hoog & stijgend \\
\hline $\begin{array}{l}\text { Bouw } \\
\text { Exploitatie van onroerend goed }\end{array}$ & $\begin{array}{r}41.000 \\
3.000\end{array}$ & $\begin{array}{l}\text { hoog } \\
\text { laag }\end{array}$ & $\begin{array}{l}\text { stijgend } \\
\text { stijgend }\end{array}$ \\
\hline Handel en reparatie & 66.000 & gemiddeld & constant \\
\hline Handel en reparatie & 66.000 & gemiddeld & constant \\
\hline Transport en communicatie & 21.500 & laag & stijgend \\
\hline $\begin{array}{l}\text { Scheep- en luchtvaart } \\
\text { Weg- en railvervoer } \\
\text { Communicatie }\end{array}$ & $\begin{array}{r}14.500 \\
6.500\end{array}$ & $\begin{array}{l}\text { erg laag } \\
\text { gemiddeld } \\
\text { gemiddeld }\end{array}$ & $\begin{array}{l}\text { sterk stijgend } \\
\text { constant } \\
\text { stijgend }\end{array}$ \\
\hline Bank- en verzekeringswezen & 10.500 & erg laag & constant \\
\hline $\begin{array}{l}\text { Bankwezen } \\
\text { Verzekeringswezen }\end{array}$ & $\begin{array}{l}6.500 \\
4.500\end{array}$ & $\begin{array}{l}\text { laag } \\
\text { laag }\end{array}$ & $\begin{array}{l}\text { constant } \\
\text { constant }\end{array}$ \\
\hline
\end{tabular}


Tabel 1.1 (vervolg)

Aantal werkenden per bedrijfssector, Overijssel, gemiddelde 2001-2002

\begin{tabular}{|c|c|c|c|}
\hline Bedrijfssector & Aantal & $\begin{array}{l}\text { Overijssel } \\
\text { t.o.v. } \\
\text { Nederland }\end{array}$ & $\begin{array}{l}\text { Trend } \\
1998-2002\end{array}$ \\
\hline Horeca en zakelijke dienstverlening & 62.000 & laag & stijgend \\
\hline Horeca & 13.500 & gemiddeld & stijgend \\
\hline Zakelijke dienstverlening & 39.000 & laag & stijgend \\
\hline Overige commerciële dienstverlening & 9.500 & gemiddeld & constant \\
\hline Kwartaire diensten & 78.500 & gemiddeld & stijgend \\
\hline Gezondheidszorg & 71.500 & gemiddeld & stijgend \\
\hline Overige kwartaire diensten & 7.000 & laag & constant \\
\hline Overheid en onderwijs & 65.500 & gemiddeld & constant \\
\hline Onderwijs & 34.500 & gemiddeld & stijgend \\
\hline Overheid & 31.000 & gemiddeld & constant \\
\hline Totaal & 465.500 & - & constant \\
\hline
\end{tabular}

Bron: CBS/ROA 
Tabel 1.2

Belangrijkste opleidingsniveaus van de werkenden per bedrijfssector, Overijssel, gemiddelde 2001-2002

Bedrijfssector

\section{Landbouw en visserij}

Basisonderwijs

VMBO

8

HAVO/NWO/MBO

28

HBO

WO

Voeding

Basisonderwijs

VMBO

HAVO/VWO/MBO

WO

\section{Chemie}

Basisonderwijs

VMBO

$\mathrm{HAVO} / \mathrm{WWO} / \mathrm{MBO}$

HBO

WO

Metaal en elektrotechniek

Basisonderwijs

VMBO

HAVO/VWO/MBO

HBO

WO

\section{Overige industrie}

Basisonderwijs

VMBO

HAVO/VWO/MBO

$\mathrm{HBO}$

WO

\section{Energie}

Basisonderwijs

VMBO

HAVO/VWO/MBO

$\mathrm{HBO}$

WO

Bouw en onroerend goed

Basisonderwijs

VMBO

8

HAVO/VWO/MBO

$\mathrm{HBO}$ 
Tabel 1.2 (vervolg)

Belangrijkste opleidingsniveaus van de werkenden per bedrijfssector, Overijssel, gemiddelde 2001-2002

Bedrijfssector

Handel en reparatie

Basisonderwijs

VMBO

8

HAVO/NWO/MBO

$\mathrm{HBO}$

29

Transport en communicatie

Basisonderwijs

VMBO

HAVO/VWO/MBO

$\mathrm{HBO}$

WO

Bank- en verzekeringswezen

Basisonderwijs

VMBO

HAVO/VWO/MBO

$\mathrm{HBO}$

WO

Horeca en zakelijke dienstverlening

Basisonderwijs

VMBO

HAVO/VWO/MBO

$\mathrm{HBO}$

WO

\section{Kwartaire diensten}

Basisonderwijs

VMBO

HAVO/VWO/MBO

HBO

WO

Overheid en onderwijs

Basisonderwijs

VMBO

HAVO/VWO/MBO

HBO

WO

Totaal

Basisonderwijs

VMBO

HAVO/VWO/MBO

$\mathrm{HBO}$

WO 
Tabel 1.3

Percentage jongeren (15-29 jaar) per bedrijfssector, Overijssel, gemiddelde 2001-2002

\begin{tabular}{|c|c|c|c|c|}
\hline Bedrijfssector & $\%$ & Typering & $\begin{array}{l}\text { Overijssel } \\
\text { t.o.v. } \\
\text { Nederland }\end{array}$ & $\begin{array}{l}\text { Trend } \\
\text { 1998-2002 }\end{array}$ \\
\hline $\begin{array}{l}\text { Landbouw en visserij } \\
\text { Voeding } \\
\text { Chemie } \\
\text { Metaal en elektrotechniek } \\
\text { Overige industrie } \\
\text { Energie } \\
\text { Bouw en onroerend goed } \\
\text { Handel en reparatie } \\
\text { Transport en communicatie } \\
\text { Bank- en verzekeringswezen } \\
\text { Horeca en zakelijke dienstverlening } \\
\text { Kwartaire diensten } \\
\text { Overheid en onderwijs }\end{array}$ & $\begin{array}{r}20 \\
30 \\
- \\
22 \\
20 \\
- \\
30 \\
35 \\
31 \\
25 \\
34 \\
23 \\
18\end{array}$ & $\begin{array}{l}\text { gemiddeld } \\
\text { gemiddeld } \\
\text { laag } \\
\text { gemiddeld } \\
\text { laag } \\
\text { erg laag } \\
\text { gemiddeld } \\
\text { erg hoog } \\
\text { hoog } \\
\text { gemiddeld } \\
\text { hoog } \\
\text { gemiddeld } \\
\text { laag }\end{array}$ & $\begin{array}{l}\text { gemiddeld } \\
\text { hoog } \\
\text { laag } \\
\text { gemiddeld } \\
\text { erg hoog } \\
\text { hoog } \\
\text { hoog } \\
\text { gemiddeld } \\
\text { gemiddeld } \\
\text { erg laag } \\
\text { laag } \\
\text { gemiddeld } \\
\text { gemiddeld }\end{array}$ & $\begin{array}{l}\text { constant } \\
\text { constant } \\
- \\
\text { sterk dalend } \\
\text { dalend } \\
- \\
\text { dalend } \\
\text { constant } \\
\text { stijgend } \\
\text { dalend } \\
\text { dalend } \\
\text { dalend } \\
\text { constant }\end{array}$ \\
\hline Totaal & 26 & - & - & dalend \\
\hline
\end{tabular}

Bron: CBS/ROA 
Tabel 1.4

Percentage ouderen (50-64 jaar) per bedrijfssector, Overijssel, gemiddelde 2001-2002

\begin{tabular}{|c|c|c|c|c|}
\hline Bedrijfssector & $\%$ & Typering & $\begin{array}{l}\text { Overijssel } \\
\text { t.o.v. } \\
\text { Nederland }\end{array}$ & $\begin{array}{l}\text { Trend } \\
1998-2002\end{array}$ \\
\hline Landbouw en visserij & 28 & hoog & hoog & constant \\
\hline Voeding & - & erg laag & gemiddeld & - \\
\hline Chemie & - & gemiddeld & gemiddeld & - \\
\hline Metaal en elektrotechniek & 19 & gemiddeld & hoog & stijgend \\
\hline Overige industrie & 22 & hoog & hoog & constant \\
\hline Energie & - & erg hoog & erg hoog & - \\
\hline Bouw en onroerend goed & 17 & gemiddeld & gemiddeld & - \\
\hline Handel en reparatie & 17 & laag & gemiddeld & stijgend \\
\hline Transport en communicatie & 18 & gemiddeld & laag & sterk stijgend \\
\hline Bank- en verzekeringswezen & - & gemiddeld & laag & - \\
\hline Horeca en zakelijke dienstverlening & 16 & laag & laag & stijgend \\
\hline Kwartaire diensten & 19 & gemiddeld & gemiddeld & sterk stijgend \\
\hline Overheid en onderwijs & 27 & hoog & gemiddeld & constant \\
\hline Totaal & 20 & - & - & stijgend \\
\hline
\end{tabular}

Bron: CBS/ROA 
Tabel 1.5

Percentage vrouwen per bedrijfssector, Overijssel, gemiddelde 2001-2002

\begin{tabular}{|c|c|c|c|c|}
\hline Bedrijfssector & $\%$ & Typering & $\begin{array}{l}\text { Overijssel } \\
\text { t.o.v. } \\
\text { Nederland }\end{array}$ & $\begin{array}{l}\text { Trend } \\
\text { 1998-2002 }\end{array}$ \\
\hline Landbouw en visserij & 26 & gemiddeld & hoog & constant \\
\hline Voeding & 23 & gemiddeld & gemiddeld & dalend \\
\hline Chemie & - & laag & laag & - \\
\hline Metaal en elektrotechniek & 12 & laag & hoog & constant \\
\hline Overige industrie & 26 & gemiddeld & erg hoog & - \\
\hline Energie & - & laag & hoog & - \\
\hline Bouw en onroerend goed & 9 & erg laag & gemiddeld & constant \\
\hline Handel en reparatie & 41 & gemiddeld & gemiddeld & constant \\
\hline Transport en communicatie & 27 & gemiddeld & gemiddeld & stijgend \\
\hline Bank- en verzekeringswezen & 49 & hoog & erg laag & constant \\
\hline Horeca en zakelijke dienstverlening & 42 & hoog & laag & constant \\
\hline Kwartaire diensten & 74 & erg hoog & gemiddeld & constant \\
\hline Overheid en onderwijs & 44 & hoog & gemiddeld & constant \\
\hline Totaal & 39 & - & - & constant \\
\hline
\end{tabular}

Bron: CBS/ROA 
Tabel 1.6

Percentage flexibel werk per bedrijfssector, Overijssel, gemiddelde 2001-2002

\begin{tabular}{|c|c|c|c|c|}
\hline Bedrijfssector & $\%$ & Typering & $\begin{array}{l}\text { Overijssel } \\
\text { t.o.v. } \\
\text { Nederland }\end{array}$ & $\begin{array}{l}\text { Trend } \\
1998-2002\end{array}$ \\
\hline $\begin{array}{l}\text { Landbouw en visserij } \\
\text { Voeding } \\
\text { Chemie } \\
\text { Metaal en elektrotechniek } \\
\text { Overige industrie } \\
\text { Energie } \\
\text { Bouw en onroerend goed } \\
\text { Handel en reparatie } \\
\text { Transport en communicatie } \\
\text { Bank- en verzekeringswezen } \\
\text { Horeca en zakelijke dienstverlening } \\
\text { Kwartaire diensten } \\
\text { Overheid en onderwijs }\end{array}$ & $\begin{array}{r}- \\
- \\
- \\
5 \\
8 \\
- \\
3 \\
9 \\
11 \\
- \\
12 \\
8 \\
5\end{array}$ & $\begin{array}{l}\text { laag } \\
\text { hoog } \\
\text { gemiddeld } \\
\text { gemiddeld } \\
\text { gemiddeld } \\
\text { laag } \\
\text { erg laag } \\
\text { gemiddeld } \\
\text { hoog } \\
\text { gemiddeld } \\
\text { hoog } \\
\text { gemiddeld } \\
\text { laag }\end{array}$ & $\begin{array}{l}\text { erg laag } \\
\text { erg hoog } \\
\text { hoog } \\
\text { gemiddeld } \\
\text { hoog } \\
\text { laag } \\
\text { gemiddeld } \\
\text { gemiddeld } \\
\text { gemiddeld } \\
\text { laag } \\
\text { gemiddeld } \\
\text { gemiddeld } \\
\text { hoog }\end{array}$ & $\begin{array}{l}- \\
- \\
- \\
\text { constant } \\
- \\
- \\
\text { sterk dalend } \\
\text { sterk dalend } \\
\text { constant } \\
- \\
\text { dalend } \\
\text { dalend } \\
\text { sterk dalend }\end{array}$ \\
\hline Totaal & 8 & - & - & dalend \\
\hline
\end{tabular}

Bron: CBS/ROA 
Tabel 1.7

Percentage deeltijdwerk per bedrijfssector, Overijssel, gemiddelde 2001-2002

\begin{tabular}{|c|c|c|c|c|}
\hline Bedrijfssector & $\%$ & Typering & $\begin{array}{l}\text { Overijssel } \\
\text { t.o.v. } \\
\text { Nederland }\end{array}$ & $\begin{array}{l}\text { Trend } \\
1998-2002\end{array}$ \\
\hline Landbouw en visserij & 23 & gemiddeld & hoog & constant \\
\hline Voeding & - & laag & gemiddeld & - \\
\hline Chemie & - & erg laag & laag & - \\
\hline Metaal en elektrotechniek & 9 & laag & gemiddeld & constant \\
\hline Overige industrie & 19 & gemiddeld & hoog & stijgend \\
\hline Energie & - & gemiddeld & erg hoog & - \\
\hline Bouw en onroerend goed & 9 & laag & hoog & constant \\
\hline Handel en reparatie & 34 & hoog & gemiddeld & stijgend \\
\hline Transport en communicatie & 28 & gemiddeld & gemiddeld & sterk stijgend \\
\hline Bank- en verzekeringswezen & 32 & gemiddeld & erg laag & sterk stijgend \\
\hline Horeca en zakelijke dienstverlening & 36 & hoog & laag & stijgend \\
\hline Kwartaire diensten & 64 & erg hoog & gemiddeld & constant \\
\hline Overheid en onderwijs & 35 & hoog & gemiddeld & stijgend \\
\hline Totaal & 32 & - & - & stijgend \\
\hline
\end{tabular}

Bron: CBS/ROA 
Tabel 1.8

Percentage zelfstandigen per bedrijfssector, Overijssel, gemiddelde 2001-2002

\begin{tabular}{|c|c|c|c|c|}
\hline Bedrijfssector & $\%$ & Typering & $\begin{array}{l}\text { Overijssel } \\
\text { t.o.v. } \\
\text { Nederland }\end{array}$ & $\begin{array}{l}\text { Trend } \\
1998-2002\end{array}$ \\
\hline Landbouw en visserij & 71 & erg hoog & hoog & constant \\
\hline Voeding & - & gemiddeld & erg hoog & - \\
\hline Chemie & - & erg laag & erg laag & - \\
\hline Metaal en elektrotechniek & 3 & laag & gemiddeld & stijgend \\
\hline Overige industrie & 4 & gemiddeld & hoog & - \\
\hline Energie & - & - & - & - \\
\hline Bouw en onroerend goed & 13 & gemiddeld & gemiddeld & constant \\
\hline Handel en reparatie & 16 & hoog & hoog & constant \\
\hline Transport en communicatie & 3 & laag & laag & sterk dalend \\
\hline Bank- en verzekeringswezen & - & gemiddeld & laag & - \\
\hline Horeca en zakelijke dienstverlening & 16 & hoog & laag & - \\
\hline Kwartaire diensten & 7 & gemiddeld & gemiddeld & constant \\
\hline Overheid en onderwijs & 2 & laag & gemiddeld & constant \\
\hline Totaal & 11 & - & - & constant \\
\hline
\end{tabular}

Bron: CBS/ROA 
Tabel 1.9

Aantal werkenden per beroepssegment, Overijssel, gemiddelde 2001-2002

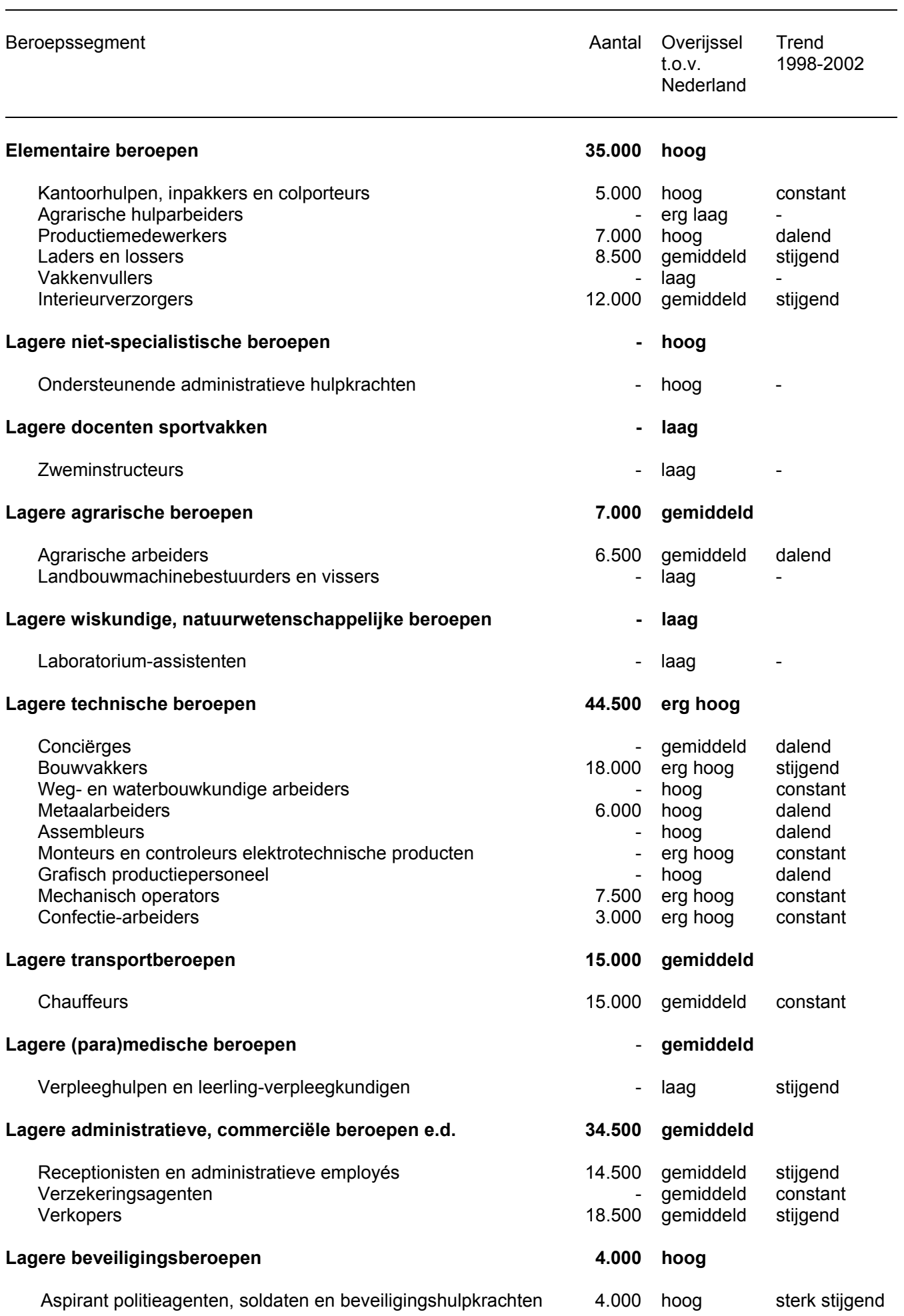


Tabel 1.9 (vervolg)

Aantal werkenden per beroepssegment, Overijssel, gemiddelde 2001-2002

\begin{tabular}{cc}
\hline Beroepssegment & Aantal Overijssel Trend \\
& t.o.v. \\
Nederland & \\
& \\
&
\end{tabular}

Lagere verzorgende beroepen

Hulpkrachten horeca en verzorging

Café- en snackbarhouders

\section{Middelbare docenten transport- en sportvakken}

Rij-instructeurs

Sportinstructeurs

Middelbare agrarische beroepen

Agrarische vakkrachten

Agrarische bedrijfshoofden

Middelbare wiskundige, natuurwetenschappelijke beroepen

Laboranten

\section{Middelbare technische beroepen}

Hoofden technische dienst

Weg- en waterbouwkundige vakkrachten

Bankwerkers en lassers

Monteurs

Elektronicamonteurs

Elektromonteurs

Grafische vakkrachten

Schoen- en kleermakers

Brandweerlieden

Procesoperators

Bakkers en slagers

\section{Middelbare transportberoepen e.d.}

Schippers en conducteurs

Administratieve transportemployés

Stewards

\section{Middelbare (para)medische beroepen}

Verplegenden en doktersassistenten

Apothekersassistenten en medisch laboranten

Medisch secretaresses

Ziekenverzorgenden

Middelbare administratieve, commerciële beroepen e.d.

Productieplanners

Programmeurs

Boekhouders en secretaresses

Commercieel employés

Winkeliers

Technisch-commercieel employés

\subsection{0 gemiddeld}

11.500 gemiddeld stijgend

- hoog

- gemiddeld

- gemiddeld stijgend

- gemiddeld dalend

11.500 erg hoog

- gemiddeld constant

11.000 erghoog dalend

- erg laag

- erg laag

58.000 erg hoog

- gemiddeld dalend

16.000 hoog constant

3.000 hoog constant

5.500 hoog dalend

16.000 hoog constant - gemiddeld -

7.500 hoog stijgend

3.000 hoog dalend

- hoog -

- gemiddeld dalend

3.500 gemiddeld dalend

- erg laag

- laag dalend

- laag stijgend

- erg laag

20.000 hoog

7.500 gemiddeld stijgend

3.000 gemiddeld stijgend

- gemiddeld constant

8.000 erg hoog sterk stijgend

63.500 gemiddeld

4.000 gemiddeld stijgend

4.500 laag stijgend

26.000 gemiddeld stijgend

17.500 gemiddeld constant

10.000 hoog constant

- hoog constant 
Tabel 1.9 (vervolg)

Aantal werkenden per beroepssegment, Overijssel, gemiddelde 2001-2002

\begin{tabular}{ll}
\hline Beroepssegment & Aantal Overijssel Trend \\
& t.o.v. \\
& Nederland \\
& \\
&
\end{tabular}

Middelbare juridische, bestuurlijke beveiligingsberoepen

Juridisch en fiscaal medewerkers

Politieagenten, onderofficieren en beveiligingsemployés

Middelbare taalkundige, culturele beroepen

Bibliotheekassistenten

Grafisch ontwerpers

Middelbare beroepen m.b.t. gedrag en maatschappij

Activiteitenbegeleiders en medewerkers arbeidsbemiddeling

Middelbare verzorgende beroepen e.d.

Verzorgend personeel

Bedrijfshoofden horeca

\section{Hogere pedagogische beroepen}

Docenten 2 e graads zonder specialisatie

Onderwijskundig medewerkers

Leraar basisonderwijs

Docenten exacte, medische en verzorgende vakken (2e graads)

Docenten landbouw en techniek (2e graads)

Docenten economisch-administratieve vakken (2e graads)

Docenten talen en expressie

Docenten sociale vakken (2e graads)

\section{Hogere landbouwkundige beroepen}

Milieuhygiënisten en agrarisch vertegenwoordigers

Hogere wiskundige, natuurwetenschappelijke beroepen

Technisch analisten

\section{Hogere technische beroepen}

Architecten en bouwkundig projectleiders

Weg- en waterbouwkundig ontwerpers en projectleiders

Bedrijfshoofden metaalbewerking

Werktuigbouwkundig ontwerpers en hoofden technische dienst

Technisch systeemanalisten

Elektrotechnisch ontwerpers en bedrijfshoofden

Procestechnologen

\section{Hogere transportberoepen}

Vliegers, scheepskapiteins en leidinggevenden transport

\section{Hogere (para)medische beroepen}

Therapeuten en verpleegkundigen

Medisch analisten
5.500 gemiddeld

- gemiddeld dalend

3.000 gemiddeld constant

2.500 hoog

- hoog

- gemiddeld -

5.500 hoog

5.500 gemiddeld stijgend

16.500 gemiddeld

14.500 hoog constant

- laag dalend

22.000 erg hoog

- erg hoog constant

- gemiddeld -

13.000 hoog stijgend

- gemiddeld constant

- hoog dalend

- erg hoog -

2.500 gemiddeld stijgend

- hoog stijgend

- hoog

- gemiddeld constant

- gemiddeld

- gemiddeld -

9.000 hoog

3.000 gemiddeld constant

- hoog

- erg hoog -

- gemiddeld stijgend

- laag

- gemiddeld -

- erg hoog .

- erg laag

- erg laag dalend

9.500 hoog

8.500 hoog stijgend - gemiddeld - 
Tabel 1.9 (vervolg)

Aantal werkenden per beroepssegment, Overijssel, gemiddelde 2001-2002

\begin{tabular}{cc}
\hline Beroepssegment & Aantal Overijssel Trend \\
& t.o.v. \\
Nederland & 1998-2002
\end{tabular}

Hogere administratieve, commerciële beroepen

Bedrijfshoofden

Organisatie-adviseurs

Systeemanalisten

Assistent accountants

Commercieel medewerkers

Technisch-bedrijfskundig medewerkers

Hogere juridische, bestuurlijke, beveiligingsberoepen

Juridisch, bestuurlijk medewerkers

Politie-inspecteurs en officieren

Hogere taalkundige, culturele beroepen

Tolken, vertalers en schrijvers

Bibliothecarissen

Kunstenaars

Hogere beroepen m.b.t. gedrag en maatschappij e.d.

Geestelijk verzorgers

Medewerkers sociaal-cultureel werk en personeel en arbeid Journalisten

Sociaal-wetenschappelijk medewerkers

\section{Hogere verzorgende beroepen}

Afdelingshoofden zorginstelling

Managers (HBO werk- en denkniveau)

Leidinggevenden

\section{Wetenschappelijke pedagogische beroepen}

Docent 1e graads zonder specialisatie

Onderwijskundigen en pedagogen

Docenten exacte, medische en verzorgende vakken (1e graads)

Docenten landbouw en techniek (1e graads)

Docenten economisch-administratieve vakken (1e graads)

Docenten letteren (1e graads)

Docenten sociale vakken (1e graads)

\section{Wetenschappelijke landbouwkundige beroepen}

Landbouwkundigen

Wetensch. wiskundige, natuurwetenschappelijke beroepen

Natuurwetenschappers

\section{Wetenschappelijke technische beroepen}

Werktuigbouwkundigen

Weg-en waterbouwkundigen

\subsection{0 laag}

$$
\begin{array}{rll}
2.500 & \text { laag } & \text { stijgend } \\
\text { - } & \text { erg laag } & \text { constant } \\
5.500 & \text { laag } & \text { stijgend } \\
4.500 & \text { laag } & \text { sterk dalend } \\
12.000 & \text { gemiddeld } & \text { constant } \\
\text { - laag } & \text { - } \\
\text { - } & \text { gemiddeld } \\
\text { - laag } & \text { dalend } \\
\text { - } & \text { gemiddeld } & \text { dalend } \\
3.000 & \text { laag } & \\
& & \\
\text { - } & \text { gemiddeld } & \text { - } \\
\text { - gemiddeld } & \text { - } \\
\text { - laag } & \text { constant }
\end{array}
$$

\subsection{0 gemiddeld}

- erg hoog -

6.500 gemiddeld stijgend

- erg laag

- laag stijgend

- laag

- laag dalend

3.000 gemiddeld

3.000 laag constant

4.500 gemiddeld

- gemiddeld dalend

- gemiddeld -

- laag constant

- erg hoog -

- erg laag

gemiddeld dalend

- laag constant

- laag

- laag

- gemiddeld

- gemiddeld -

2.500 laag

- gemiddeld stijgend

- erg laag dalend 
Tabel 1.9 (vervolg)

Aantal werkenden per beroepssegment, Overijssel, gemiddelde 2001-2002

\begin{tabular}{|c|c|c|c|}
\hline Beroepssegment & Aantal & $\begin{array}{l}\text { Overijssel } \\
\text { t.o.v. } \\
\text { Nederland }\end{array}$ & $\begin{array}{l}\text { Trend } \\
\text { 1998-2002 }\end{array}$ \\
\hline Wetenschappelijke technische beroepen (vervolg) & 2.500 & laag & \\
\hline $\begin{array}{l}\text { Elektrotechnici } \\
\text { Materiaalkundigen }\end{array}$ & - & $\begin{array}{l}\text { erg laag } \\
\text { gemiddeld }\end{array}$ & $\begin{array}{l}\text { stijgend } \\
\text { sterk dalend }\end{array}$ \\
\hline Wetenschappelijke (para)medische beroepen & 4.000 & gemiddeld & \\
\hline $\begin{array}{l}\text { Artsen } \\
\text { Apothekers }\end{array}$ & $\begin{array}{r}3.500 \\
-\end{array}$ & $\begin{array}{l}\text { gemiddeld } \\
\text { laag }\end{array}$ & $\begin{array}{l}\text { stijgend } \\
\text { constant }\end{array}$ \\
\hline $\begin{array}{l}\text { Wetenschappelijke economische, administratieve } \\
\text { beroepen }\end{array}$ & 4.500 & laag & \\
\hline $\begin{array}{l}\text { Economen } \\
\text { Organisatiedeskundigen } \\
\text { Informatici } \\
\text { Accountants }\end{array}$ & $\begin{array}{l}- \\
- \\
-\end{array}$ & $\begin{array}{l}\text { erg laag } \\
\text { erg laag } \\
\text { laag } \\
\text { gemiddeld }\end{array}$ & $\begin{array}{l}\text { constant } \\
- \\
- \\
\text { constant }\end{array}$ \\
\hline Wetenschappelijke juridische, bestuurlijke beroepen & 3.000 & laag & \\
\hline Juristen & 3.000 & laag & constant \\
\hline $\begin{array}{l}\text { Wetenschappelijke beroepen m.b.t. gedrag en } \\
\text { maatschappij }\end{array}$ & - & erg laag & \\
\hline $\begin{array}{l}\text { Geestelijken } \\
\text { Hoofden sociaal-cultureel werk en personeel en arbeid } \\
\text { Taalkundigen } \\
\text { Sociaal-wetenschappelijk onderzoekers }\end{array}$ & $\begin{array}{l}- \\
- \\
-\end{array}$ & $\begin{array}{l}\text { gemiddeld } \\
\text { gemiddeld } \\
\text { erg laag } \\
\text { erg laag }\end{array}$ & $\begin{array}{l}- \\
\text { dalend } \\
- \\
\text { dalend }\end{array}$ \\
\hline Managers (wetenschappelijk werk- en denkniveau) & 6.000 & gemiddeld & \\
\hline Managers & 6.000 & gemiddeld & stijgend \\
\hline Totaal & 465.500 & - & constant \\
\hline
\end{tabular}

Bron: CBS/ROA 
Tabel 1.10

Percentage jongeren (15-29 jaar) per beroepssegment, Overijssel, gemiddelde 2001-2002

\begin{tabular}{|c|c|c|c|c|}
\hline Beroepssegment & $\%$ & Typering & $\begin{array}{l}\text { Overijssel } \\
\text { t.o.v. } \\
\text { Nederland }\end{array}$ & $\begin{array}{l}\text { Trend } \\
1998-2002\end{array}$ \\
\hline Elementaire beroepen & 34 & hoog & gemiddeld & dalend \\
\hline Lagere niet-specialistische beroepen & - & hoog & gemiddeld & - \\
\hline Lagere docenten sportvakken & - & erg hoog & hoog & - \\
\hline Lagere agrarische beroepen & 35 & hoog & gemiddeld & constant \\
\hline Lagere wiskundige, natuurwetenschappelijke beroepen & - & erg laag & erg laag & - $\quad$ \\
\hline Lagere technische beroepen & 25 & gemiddeld & hoog & sterk dalend \\
\hline Lagere transportberoepen & 23 & gemiddeld & gemiddeld & - \\
\hline Lagere (para)medische beroepen & - & erg hoog & laag & - \\
\hline Lagere administratieve, commerciële beroepen e.d. & 40 & erg hoog & gemiddeld & constant \\
\hline Lagere beveiligingsberoepen & - & hoog & gemiddeld & \\
\hline Lagere verzorgende beroepen & 39 & hoog & gemiddeld & constant \\
\hline Middelbare docenten transport-, sportvakken & - & laag & erg laag & - \\
\hline Middelbare agrarische beroepen & - & laag & hoog & - \\
\hline Middelbare wiskundige, natuurwetenschappelijke beroepen & - & erg hoog & laag & - \\
\hline Middelbare technische beroepen & 25 & gemiddeld & hoog & constant \\
\hline Middelbare transportberoepen e.d. & - & gemiddeld & laag & - \\
\hline Middelbare (para)medische beroepen & 29 & hoog & hoog & - \\
\hline Middelbare administratieve, commerciële beroepen e.d. & 26 & gemiddeld & gemiddeld & dalend \\
\hline Middelbare juridische, bestuurlijke beveiligingsberoepen & & gemiddeld & gemiddeld & - \\
\hline Middelbare taalkundige, culturele beroepen & - & gemiddeld & gemiddeld & - \\
\hline Middelbare beroepen mbt. gedrag en maatschappij & - & hoog & hoog & - \\
\hline Middelbare verzorgende beroepen e.d. & 35 & hoog & gemiddeld & dalend \\
\hline Hogere pedagogische beroepen & 17 & laag & hoog & - \\
\hline Hogere landbouwkundige beroepen & - & gemiddeld & gemiddeld & - \\
\hline Hogere wiskundige, natuurwetenschappelijke beroepen & - & gemiddeld & gemiddeld & - \\
\hline Hogere technische beroepen & - & gemiddeld & gemiddeld & - \\
\hline Hogere transportberoepen & - & laag & laag & - \\
\hline Hogere (para)medische beroepen & - & gemiddeld & hoog & 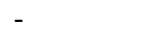 \\
\hline Hogere administratieve, commerciële beroepen & 18 & gemiddeld & laag & sterk dalend \\
\hline Hogere juridische, bestuurlijke, beveiligingsberoepen & - & laag & laag & - $\quad$ \\
\hline Hogere taalkundige, culturele beroepen & - & erg laag & laag & - \\
\hline Hogere beroepen mbt. gedrag en maatschappij e.d. & - & gemiddeld & gemiddeld & - \\
\hline Hogere verzorgende beroepen & - & & - & - \\
\hline Managers (HBO werk- en denkniveau) & - & laag & erg hoog & - \\
\hline Wetenschappelijke pedagogische beroepen & - & gemiddeld & erg hoog & - \\
\hline Wetenschappelijke landbouwkundige beroepen & - & erg laag & erg laag & - \\
\hline Wetensch. wiskundige, natuurwetenschappelijke beroepen & - & erg laag & erg laag & - \\
\hline Wetenschappelijke technische beroepen & - & gemiddeld & gemiddeld & - \\
\hline Wetenschappelijke (para)medische beroepen & - & gemiddeld & erg hoog & - \\
\hline Wetenschappelijke economische, administratieve beroepen & - & laag & laag & - \\
\hline Wetenschappelijke juridische, bestuurlijke beroepen & - & hoog & hoog & - \\
\hline Wetenschappelijke beroepen mbt. gedrag en maatschappij & - & laag & laag & - \\
\hline Managers (wetenschappelijk werk- en denkniveau) & - & laag & erg hoog & - \\
\hline Totaal & 26 & - & - & dalend \\
\hline
\end{tabular}

Bron: CBS/ROA 
Tabel 1.11

Percentage ouderen (50-64 jaar) per beroepssegment, Overijssel, gemiddelde 2001-2002

\begin{tabular}{|c|c|c|c|c|}
\hline Beroepssegment & $\%$ & Typering & $\begin{array}{l}\text { Overijssel } \\
\text { t.o.v. } \\
\text { Nederland }\end{array}$ & $\begin{array}{l}\text { Trend } \\
1998-2002\end{array}$ \\
\hline Elementaire beroepen & 18 & gemiddeld & gemiddeld & stijgend \\
\hline Lagere niet-specialistische beroepen & - & gemiddeld & erg hoog & - \\
\hline Lagere docenten sportvakken & - & erg hoog & erg hoog & - \\
\hline Lagere agrarische beroepen & - & gemiddeld & hoog & - \\
\hline Lagere wiskundige, natuurwetenschappelijke beroepen & - & erg hoog & gemiddeld & - \\
\hline Lagere technische beroepen & 18 & gemiddeld & hoog & constant \\
\hline Lagere transportberoepen & 26 & hoog & gemiddeld & sterk stijgend \\
\hline Lagere (para)medische beroepen & - & erg laag & laag & - \\
\hline Lagere administratieve, commerciële beroepen e.d. & 15 & laag & gemiddeld & - \\
\hline Lagere beveiligingsberoepen & - & laag & gemiddeld & - \\
\hline Lagere verzorgende beroepen & - & gemiddeld & gemiddeld & - \\
\hline Middelbare docenten transport-, sportvakken & - & laag & laag & - \\
\hline Middelbare agrarische beroepen & 37 & hoog & erg hoog & constant \\
\hline Middelbare wiskundige, natuurwetenschappelijke beroepen & - & erg laag & erg laag & - \\
\hline Middelbare technische beroepen & 21 & gemiddeld & hoog & - \\
\hline Middelbare transportberoepen e.d. & - & hoog & laag & - \\
\hline Middelbare (para)medische beroepen & 11 & laag & gemiddeld & stijgend \\
\hline Middelbare administratieve, commerciële beroepen e.d. & 18 & gemiddeld & gemiddeld & stijgend \\
\hline Middelbare juridische, bestuurlijke beveiligingsberoepen & - & gemiddeld & gemiddeld & - \\
\hline Middelbare taalkundige, culturele beroepen & - & gemiddeld & hoog & - \\
\hline Middelbare beroepen mbt. gedrag en maatschappij & - & laag & hoog & - \\
\hline Middelbare verzorgende beroepen e.d. & 16 & laag & gemiddeld & - \\
\hline Hogere pedagogische beroepen & 26 & hoog & hoog & constant \\
\hline Hogere landbouwkundige beroepen & - & hoog & erg hoog & - \\
\hline Hogere wiskundige, natuurwetenschappelijke beroepen & - & laag & gemiddeld & - \\
\hline Hogere technische beroepen & - & hoog & hoog & - \\
\hline Hogere transportberoepen & - & gemiddeld & laag & - \\
\hline Hogere (para)medische beroepen & - & gemiddeld & hoog & - \\
\hline Hogere administratieve, commerciële beroepen & 21 & gemiddeld & gemiddeld & constant \\
\hline Hogere juridische, bestuurlijke, beveiligingsberoepen & - & hoog & gemiddeld & - \\
\hline Hogere taalkundige, culturele beroepen & - & erg hoog & hoog & - \\
\hline Hogere beroepen mbt. gedrag en maatschappij e.d. & - & gemiddeld & gemiddeld & - \\
\hline Hogere verzorgende beroepen & - & erg laag & erg laag & - \\
\hline Managers (HBO werk- en denkniveau) & - & hoog & laag & - \\
\hline Wetenschappelijke pedagogische beroepen & - & erg hoog & gemiddeld & - \\
\hline Wetenschappelijke landbouwkundige beroepen & - & erg laag & erg laag & - \\
\hline Wetensch. wiskundige, natuurwetenschappelijke beroepen & - & gemiddeld & gemiddeld & - \\
\hline Wetenschappelijke technische beroepen & - & gemiddeld & gemiddeld & - \\
\hline Wetenschappelijke (para)medische beroepen & - & gemiddeld & laag & - \\
\hline Wetenschappelijke economische, administratieve beroepen & - & laag & laag & - \\
\hline Wetenschappelijke juridische, bestuurlijke beroepen & - & laag & laag & - \\
\hline Wetenschappelijke beroepen mbt. gedrag en maatschappij & - & gemiddeld & erg laag & - \\
\hline Managers (wetenschappelijk werk- en denkniveau) & - & hoog & laag & - \\
\hline Totaal & 20 & - & - & stijgend \\
\hline
\end{tabular}

Bron: CBS/ROA 
Tabel 1.12

Percentage vrouwen per beroepssegment, Overijssel, gemiddelde 2001-2002

\begin{tabular}{llll}
\hline Beroepssegment & \% Typering $\begin{array}{l}\text { Overijssel Trend } \\
\text { t.o.v. } \\
\text { Nederland }\end{array}$ & \\
& & & 1998-2002 \\
& & \\
& &
\end{tabular}

Elementaire beroepen

Lagere niet-specialistische beroepen

Lagere docenten sportvakken

Lagere agrarische beroepen

Lagere wiskundige, natuurwetenschappelijke beroepen

Lagere technische beroepen

Lagere transportberoepen

Lagere (para)medische beroepen

Lagere administratieve, commerciële beroepen e.d.

Lagere beveiligingsberoepen

Lagere verzorgende beroepen

Middelbare docenten transport-, sportvakken

Middelbare agrarische beroepen

Middelbare wiskundige, natuurwetenschappelijke beroepen

Middelbare technische beroepen

Middelbare transportberoepen e.d.

Middelbare (para)medische beroepen

Middelbare administratieve, commerciële beroepen e.d.

Middelbare juridische, bestuurlijke beveiligingsberoepen

Middelbare taalkundige, culturele beroepen

Middelbare beroepen mbt. gedrag en maatschappij

Middelbare verzorgende beroepen e.d.

Hogere pedagogische beroepen

Hogere landbouwkundige beroepen

Hogere wiskundige, natuurwetenschappelijke beroepen

Hogere technische beroepen

Hogere transportberoepen

Hogere (para)medische beroepen

Hogere administratieve, commerciële beroepen

Hogere juridische, bestuurlijke, beveiligingsberoepen

Hogere taalkundige, culturele beroepen

Hogere beroepen mbt. gedrag en maatschappij e.d.

Hogere verzorgende beroepen

Managers (HBO werk- en denkniveau)

Wetenschappelijke pedagogische beroepen

Wetenschappelijke landbouwkundige beroepen

Wetensch. wiskundige, natuurwetenschappelijke beroepen

Wetenschappelijke technische beroepen

Wetenschappelijke (para)medische beroepen

Wetenschappelijke economische, administratieve beroepen

Wetenschappelijke juridische, bestuurlijke beroepen

Wetenschappelijke beroepen mbt. gedrag en maatschappij

Managers (wetenschappelijk werk- en denkniveau)

Totaal
45 gemiddeld hoog constant

- gemiddeld gemiddeld -

- erg hoog gemiddeld -

- gemiddeld gemiddeld -

- erglaag erg laag -

10 laag erg hoog dalend

- laag gemiddeld -

- erg hoog gemiddeld -

75 hoog gemiddeld constant

- laag gemiddeld -

73 hoog gemiddeld constant

- gemiddeld gemiddeld -

29 gemiddeld erg hoog sterk stijgend

- hoog gemiddeld -

5 erg laag hoog constant

- laag erg laag -

88 erghoog hoog constant

47 gemiddeld gemiddeld constant

- gemiddeld gemiddeld -

- hoog erg hoog -

- hoog hoog constant

75 hoog hoog constant

62 hoog hoog stijgend

- laag gemiddeld -

- gemiddeld hoog

- laag hoog -

- gemiddeld erg hoog -

75 hoog hoog constant

27 gemiddeld laag constant

- gemiddeld laag -

- gemiddeld laag -

57 hoog gemiddeld constant

- erg hoog gemiddeld -

- laag laag

- gemiddeld laag

- erg laag erg laag -

- erg laag erg laag -

- laag laag

- gemiddeld laag

- laag laag

- gemiddeld gemiddeld -

- gemiddeld laag

- gemiddeld gemiddeld -

39 -

constant

Bron: CBS/ROA 
Tabel 1.13

Percentage flexibel werk per beroepssegment, Overijssel, gemiddelde 2001-2002

Beroepssegment
$\%$ Typering

$\begin{array}{lll}\% \text { Typering } & \text { Overijssel } & \text { Trend } \\ \text { t.o.v. } & 1998-2002 \\ & \text { Nederland }\end{array}$

Elementaire beroepen

Lagere niet-specialistische beroepen

Lagere docenten sportvakken

Lagere agrarische beroepen

Lagere wiskundige, natuurwetenschappelijke beroepen

Lagere technische beroepen

Lagere transportberoepen

Lagere (para)medische beroepen

Lagere administratieve, commerciële beroepen e.d.

Lagere beveiligingsberoepen

Lagere verzorgende beroepen

Middelbare docenten transport-, sportvakken

Middelbare agrarische beroepen

Middelbare wiskundige, natuurwetenschappelijke beroepen

Middelbare technische beroepen

Middelbare transportberoepen e.d.

Middelbare (para)medische beroepen

Middelbare administratieve, commerciële beroepen e.d.

Middelbare juridische, bestuurlijke beveiligingsberoepen

Middelbare taalkundige, culturele beroepen

Middelbare beroepen mbt. gedrag en maatschappij

Middelbare verzorgende beroepen e.d.

Hogere pedagogische beroepen

Hogere landbouwkundige beroepen

Hogere wiskundige, natuurwetenschappelijke beroepen

Hogere technische beroepen

Hogere transportberoepen

Hogere (para)medische beroepen

Hogere administratieve, commerciële beroepen

Hogere juridische, bestuurlijke, beveiligingsberoepen

Hogere taalkundige, culturele beroepen

Hogere beroepen mbt. gedrag en maatschappij e.d.

Hogere verzorgende beroepen

Managers (HBO werk- en denkniveau)

Wetenschappelijke pedagogische beroepen

Wetenschappelijke landbouwkundige beroepen

Wetensch. wiskundige, natuurwetenschappelijke beroepen

Wetenschappelijke technische beroepen

Wetenschappelijke (para)medische beroepen

Wetenschappelijke economische, administratieve beroepen

Wetenschappelijke juridische,bestuurlijke beroepen

Wetenschappelijke beroepen mbt. gedrag en maatschappij

Managers (wetenschappelijk werk- en denkniveau)

Totaal

Bron: CBS/ROA

Van flexibel werk is sprake bij uitzendkrachten, oproepkrachten, invalkrachten, contracten zonder een vast aantal arbeidsuren en indien geen vast dienstverband is overeengekomen.

\begin{tabular}{|c|c|c|c|}
\hline 21 & erg hoog & hoog & dalend \\
\hline- & erg hoog & gemiddeld & - \\
\hline- & erg laag & erg laag & - \\
\hline - & hoog & gemiddeld & - \\
\hline - & erg laag & erg laag & - \\
\hline 8 & gemiddeld & erg hoog & dalend \\
\hline - & hoog & gemiddeld & - \\
\hline - & hoog & hoog & - \\
\hline 15 & hoog & hoog & constant \\
\hline - & laag & laag & - \\
\hline - & erg hoog & gemiddeld & - \\
\hline & & & - \\
\hline- & hoog & hoog & - \\
\hline- & erg laag & erg laag & - \\
\hline - & erg hoog & gemiddeld & - \\
\hline 4 & gemiddeld & hoog & constant \\
\hline - & hoog & laag & - \\
\hline 5 & gemiddeld & gemiddeld & sterk dalend \\
\hline 6 & gemiddeld & gemiddeld & dalend \\
\hline- & laag & laag & - \\
\hline- & hoog & hoog & - \\
\hline- & hoog & hoog & - \\
\hline - & gemiddeld & gemiddeld & - \\
\hline 7 & gemiddeld & erg hoog & sterk dalend \\
\hline- & gemiddeld & erg hoog & - \\
\hline- & - & - & - \\
\hline- & gemiddeld & gemiddeld & - \\
\hline - & erg laag & erg laag & - \\
\hline- & gemiddeld & erg hoog & - \\
\hline 2 & laag & laag & sterk dalend \\
\hline- & - & - & - \\
\hline- & gemiddeld & laag & - \\
\hline - & gemiddeld & hoog & - \\
\hline- & - & - & - \\
\hline - & gemiddeld & gemiddeld & - \\
\hline- & erg laag & erg laag & - \\
\hline- & - & - & - \\
\hline- & - & - & - \\
\hline- & erg laag & erg laag & - \\
\hline- & laag & gemiddeld & - \\
\hline- & laag & gemiddeld & - \\
\hline- & gemiddeld & gemiddeld & - \\
\hline- & gemiddeld & gemiddeld & - \\
\hline- & laag & laag & - \\
\hline 8 & - & - & dalend \\
\hline
\end{tabular}


Tabel 1.14

Percentage deeltijdwerk per beroepssegment, Overijssel, gemiddelde 2001-2002

\begin{tabular}{|c|c|c|c|c|}
\hline Beroepssegment & $\%$ & Typering & $\begin{array}{l}\text { Overijssel } \\
\text { t.o.v. } \\
\text { Nederland }\end{array}$ & $\begin{array}{l}\text { Trend } \\
\text { 1998-2002 }\end{array}$ \\
\hline Elementaire beroepen & 47 & gemiddeld & hoog & stijgend \\
\hline Lagere niet-specialistische beroepen & - & erg hoog & erg hoog & - \\
\hline Lagere docenten sportvakken & - & erg hoog & gemiddeld & - \\
\hline Lagere agrarische beroepen & - & gemiddeld & gemiddeld & - \\
\hline Lagere wiskundige, natuurwetenschappelijke beroepen & - & & - & - \\
\hline Lagere technische beroepen & 12 & laag & hoog & constant \\
\hline Lagere transportberoepen & - & gemiddeld & gemiddeld & - \\
\hline Lagere (para)medische beroepen & - & erg hoog & gemiddeld & - \\
\hline Lagere administratieve, commerciële beroepen e.d. & 64 & hoog & gemiddeld & stijgend \\
\hline Lagere beveiligingsberoepen & - & erg laag & laag & \\
\hline Lagere verzorgende beroepen & 72 & hoog & gemiddeld & constant \\
\hline Middelbare docenten transport-, sportvakken & - & gemiddeld & laag & - \\
\hline Middelbare agrarische beroepen & - & gemiddeld & erg hoog & - \\
\hline Middelbare wiskundige, natuurwetenschappelijke beroepen & - & hoog & erg hoog & - \\
\hline Middelbare technische beroepen & 7 & erg laag & hoog & constant \\
\hline Middelbare transportberoepen e.d. & - & laag & laag & - \\
\hline Middelbare (para)medische beroepen & 70 & hoog & hoog & stijgend \\
\hline Middelbare administratieve, commerciële beroepen e.d. & 28 & gemiddeld & gemiddeld & stijgend \\
\hline Middelbare juridische, bestuurlijke beveiligingsberoepen & - & gemiddeld & gemiddeld & - \\
\hline Middelbare taalkundige, culturele beroepen & - & gemiddeld & erg hoog & - \\
\hline Middelbare beroepen mbt. gedrag en maatschappij & 59 & hoog & hoog & stijgend \\
\hline Middelbare verzorgende beroepen e.d. & 66 & hoog & hoog & constant \\
\hline Hogere pedagogische beroepen & 52 & hoog & hoog & sterk stijgend \\
\hline Hogere landbouwkundige beroepen & - & laag & hoog & - \\
\hline Hogere wiskundige, natuurwetenschappelijke beroepen & - & gemiddeld & gemiddeld & - \\
\hline Hogere technische beroepen & - & erg laag & gemiddeld & - \\
\hline Hogere transportberoepen & - & laag & gemiddeld & - \\
\hline Hogere (para)medische beroepen & 53 & hoog & gemiddeld & constant \\
\hline Hogere administratieve, commerciële beroepen & 16 & gemiddeld & laag & sterk stijgend \\
\hline Hogere juridische, bestuurlijke, beveiligingsberoepen & - & laag & erg laag & - \\
\hline Hogere taalkundige, culturele beroepen & - & gemiddeld & laag & - \\
\hline Hogere beroepen mbt. gedrag en maatschappij e.d. & 46 & gemiddeld & gemiddeld & constant \\
\hline Hogere verzorgende beroepen & - & erg hoog & gemiddeld & - \\
\hline Managers (HBO werk- en denkniveau) & - & laag & gemiddeld & - \\
\hline Wetenschappelijke pedagogische beroepen & - & gemiddeld & laag & - \\
\hline Wetenschappelijke landbouwkundige beroepen & - & hoog & hoog & - \\
\hline Wetensch. wiskundige, natuurwetenschappelijke beroepen & - & erg laag & erg laag & - \\
\hline Wetenschappelijke technische beroepen & - & laag & gemiddeld & - \\
\hline Wetenschappelijke (para)medische beroepen & - & gemiddeld & erg laag & - \\
\hline Wetenschappelijke economische, administratieve beroepen & - & laag & laag & - \\
\hline Wetenschappelijke juridische,bestuurlijke beroepen & - & gemiddeld & erg laag & - \\
\hline Wetenschappelijke beroepen mbt. gedrag en maatschappij & - & gemiddeld & laag & - \\
\hline Managers (wetenschappelijk werk- en denkniveau) & - & laag & laag & - \\
\hline Totaal & 32 & - & - & stijgend \\
\hline
\end{tabular}

Bron: CBS/ROA 
Tabel 1.15

Percentage zelfstandigen per beroepssegment, Overijssel, gemiddelde 2001-2002

\begin{tabular}{|c|c|c|c|c|}
\hline Beroepssegment & $\%$ & Typering & $\begin{array}{l}\text { Overijssel } \\
\text { t.o.v. } \\
\text { Nederland }\end{array}$ & $\begin{array}{l}\text { Trend } \\
1998-2002\end{array}$ \\
\hline Elementaire beroepen & 4 & laag & hoog & sterk stijgend \\
\hline Lagere niet-specialistische beroepen & - & hoog & erg hoog & - \\
\hline Lagere docenten sportvakken & - & & - & - \\
\hline Lagere agrarische beroepen & - & gemiddeld & gemiddeld & - \\
\hline Lagere technische beroepen & 7 & gemiddeld & gemiddeld & - \\
\hline Lagere transportberoepen & - & laag & laag & - \\
\hline Lagere (para)medische beroepen & - & erg laag & erg laag & - \\
\hline $\begin{array}{l}\text { Lagere administratieve, commerciële beroepen e.d. } \\
\text { Lagere beveiligingsberoepen }\end{array}$ & 3 & laag & gemiddeld & - \\
\hline Lagere verzorgende beroepen & - & gemiddeld & hoog & - \\
\hline Middelbare docenten transport-, sportvakken & - & erg hoog & gemiddeld & - \\
\hline Middelbare agrarische beroepen & 92 & erg hoog & erg hoog & constant \\
\hline Middelbare wiskundige, natuurwetenschappelijke beroepen & - & - & - & - \\
\hline Middelbare technische beroepen & 9 & gemiddeld & gemiddeld & - \\
\hline Middelbare transportberoepen e.d. & - & hoog & gemiddeld & - \\
\hline Middelbare (para)medische beroepen & 1 & laag & laag & sterk dalend \\
\hline Middelbare administratieve, commerciële beroepen e.d. & 9 & gemiddeld & gemiddeld & dalend \\
\hline Middelbare juridische, bestuurlijke beveiligingsberoepen & - & erg laag & laag & - \\
\hline Middelbare taalkundige, culturele beroepen & - & hoog & hoog & - \\
\hline Middelbare beroepen mbt. gedrag en maatschappij & - & erg laag & laag & - \\
\hline Middelbare verzorgende beroepen e.d. & 13 & gemiddeld & gemiddeld & - \\
\hline Hogere pedagogische beroepen & 3 & laag & hoog & sterk stijgend \\
\hline Hogere landbouwkundige beroepen & - & erg laag & erg laag & - \\
\hline Hogere wiskundige, natuurwetenschappelijke beroepen & - & & - & - \\
\hline Hogere technische beroepen & - & gemiddeld & gemiddeld & - \\
\hline Hogere transportberoepen & - & gemiddeld & hoog & - \\
\hline Hogere (para)medische beroepen & - & hoog & hoog & - \\
\hline Hogere administratieve, commerciële beroepen & 26 & hoog & gemiddeld & stijgend \\
\hline Hogere juridische, bestuurlijke, beveiligingsberoepen & - & laag & laag & - \\
\hline Hogere taalkundige, culturele beroepen & - & hoog & laag & - \\
\hline Hogere beroepen mbt. gedrag en maatschappij e.d. & - & gemiddeld & gemiddeld & - \\
\hline Hogere verzorgende beroepen & - & & & - \\
\hline Managers (HBO werk- en denkniveau) & - & hoog & hoog & - \\
\hline Wetenschappelijke pedagogische beroepen & - & laag & erg laag & - \\
\hline Wetenschappelijke landbouwkundige beroepen & - & erg hoog & erg hoog & - \\
\hline Wetensch. wiskundige, natuurwetenschappelijke beroepen & - & & - & - \\
\hline Wetenschappelijke technische beroepen & - & gemiddeld & laag & - \\
\hline Wetenschappelijke (para)medische beroepen & - & erg hoog & gemiddeld & - \\
\hline Wetenschappelijke economische, administratieve beroepen & - & gemiddeld & gemiddeld & - \\
\hline Wetenschappelijke juridische, bestuurlijke beroepen & - & gemiddeld & erg laag & - \\
\hline Wetenschappelijke beroepen mbt. gedrag en maatschappij & - & gemiddeld & gemiddeld & - \\
\hline Managers (wetenschappelijk werk- en denkniveau) & - & gemiddeld & erg hoog & - \\
\hline Totaal & 11 & - & - & constant \\
\hline
\end{tabular}

Bron: CBS/ROA 
Tabel 1.16

Aantal werkenden per opleidingstype, Overijssel, gemiddelde 2001-2002

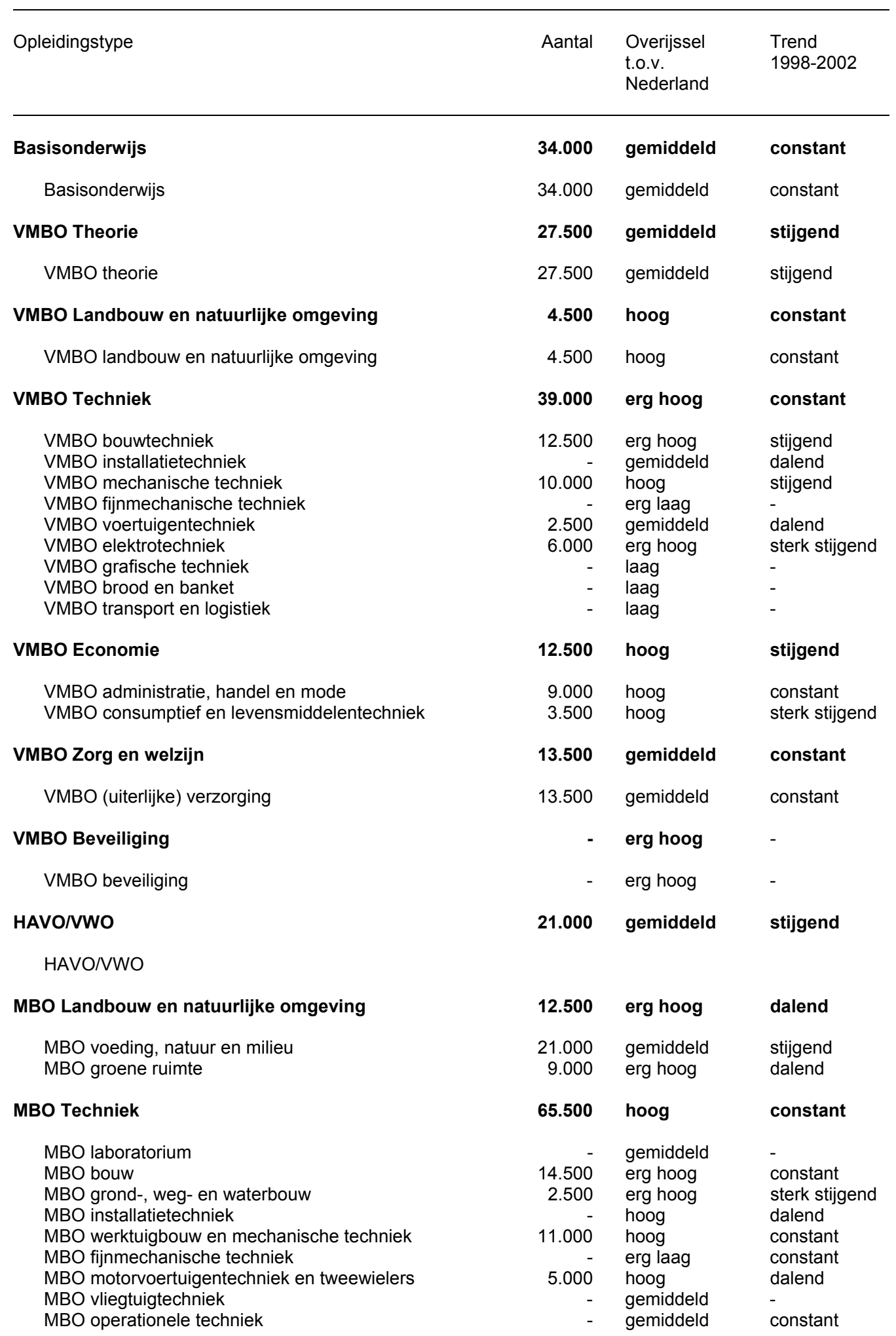


Tabel 1.16 (vervolg)

Aantal werkenden per opleidingstype, Overijssel, gemiddelde 2001-2002

\begin{tabular}{|c|c|c|c|}
\hline Opleidingstype & Aantal & $\begin{array}{l}\text { Overijssel } \\
\text { t.o.v. } \\
\text { Nederland }\end{array}$ & $\begin{array}{l}\text { Trend } \\
\text { 1998-2002 }\end{array}$ \\
\hline
\end{tabular}

MBO Techniek (vervolg)

MBO elektrotechniek

MBO grafische techniek

MBO procestechniek

MBO brood en banket

MBO levensmiddelentechniek/vleesverwerking

$\mathrm{MBO}$ vervoer

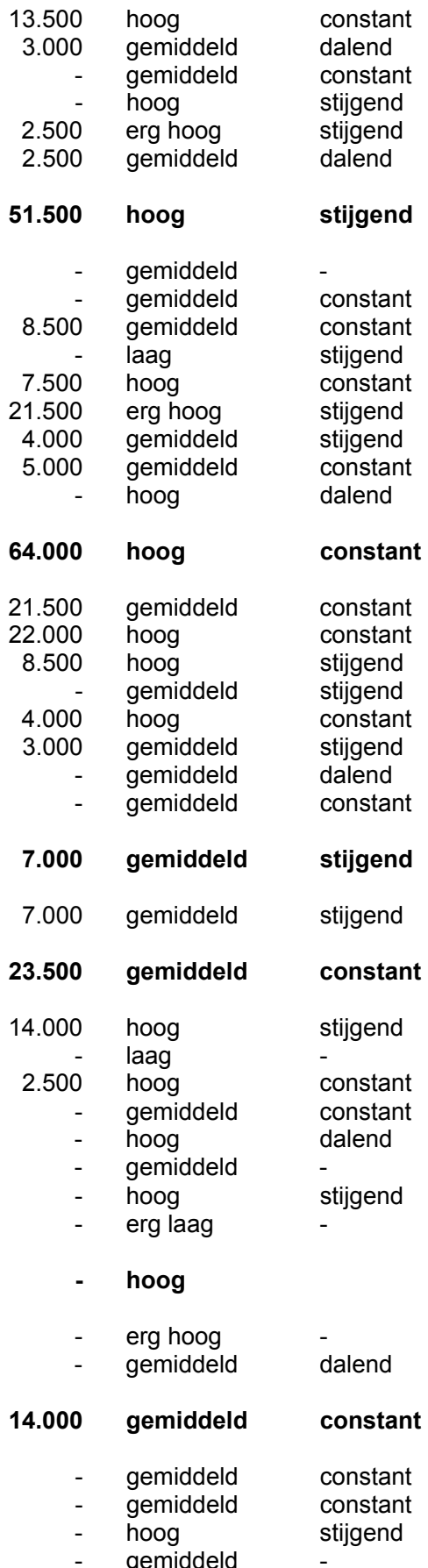

MBO apothekersassistent

$M B O$ verpleging

MBO gezondheidstechniek

MBO sociaal-pedagogisch en welzijn

$M B O$ verzorging

MBO uiterlijke verzorging

MBO horeca

MBO beweging en therapie

MBO Economie

MBO administratie en logistiek

MBO handel

MBO secretariaat

MBO toerisme en recreatie

MBO facilitaire dienstverlening

MBO ICT

MBO geld, bank en belastingen

$\mathrm{MBO}$ verzekeringswezen

MBO Openbare orde en veiligheid

MBO openbare orde en veiligheid

HBO Onderwijs en tolk en vertaler

HBO lerarenopleiding basisonderwijs

HBO lerarenopleiding talen

HBO lerarenopleiding natuur en techniek

HBO lerarenopleiding economie en maatschappij

HBO lerarenopleiding lichamelijke opvoeding

HBO lerarenopleiding medisch en verzorging

HBO lerarenopleiding expressie

$\mathrm{HBO}$ tolk en vertaler

\section{HBO Landbouw}

HBO landbouw en veeteelt

HBO milieukunde en levensmiddelentechnologie

\section{HBO Techniek}

HBO laboratorium

HBO bouwkunde

HBO civiele techniek

HBO werktuigbouwkunde

- $\quad$ gemiddeld 
Tabel 1.16 (vervolg)

Aantal werkenden per opleidingstype, Overijssel, gemiddelde 2001-2002

\begin{tabular}{lll}
\hline Opleidingstype & Aantal & Overijssel \\
& & t.o.v. \\
& Nederland & 1998-2002 \\
& & \\
\hline
\end{tabular}

\section{HBO Techniek (vervolg)}

HBO elektrotechniek

$\mathrm{HBO}$ informatica

$\mathrm{HBO}$ chemische technologie

HBO vervoer en logistiek

\section{HBO Paramedisch}

HBO verpleegkunde

HBO (fysio)therapie

$\mathrm{HBO}$ voeding

$\mathrm{HBO}$ radiologie

\section{HBO Economie}

HBO accountancy en bedrijfseconomie

HBO commerciële economie

HBO toerisme en recreatie

HBO recht en bestuur

$\mathrm{HBO}$ secretariaat

HBO bedrijfskunde

\section{HBO Sociaal-cultureel}

HBO communicatie en journalistiek

HBO maatschappelijk werk en hulpverlening

HBO personeel en arbeid

HBO bibliotheek en documentatie

\section{HBO Kunst}

HBO uitvoerende en beeldende kunsten

\section{HBO Openbare orde en veiligheid}

HBO openbare orde en veiligheid

WO Letteren en theologie

WO letteren

WO theologie

WO Landbouw en milieukunde

WO landbouw en milieukunde

\section{wo Techniek}

WO wiskunde en natuurwetenschappen

WO bouwkunde

WO civiele techniek

WO werktuigbouwkunde

WO elektrotechniek

WO informatica en bestuurlijke informatiekunde

\begin{tabular}{|c|c|c|}
\hline $\begin{array}{r}3.500 \\
2.500 \\
- \\
-\end{array}$ & $\begin{array}{l}\text { hoog } \\
\text { gemiddeld } \\
\text { gemiddeld } \\
\text { erg laag }\end{array}$ & $\begin{array}{l}\text { stijgend } \\
\text { constant } \\
\text { constant } \\
-\end{array}$ \\
\hline 8.500 & gemiddeld & constant \\
\hline $\begin{array}{r}4.000 \\
3.000 \\
- \\
-\end{array}$ & $\begin{array}{l}\text { gemiddeld } \\
\text { gemiddeld } \\
\text { erg laag } \\
\text { erg hoog }\end{array}$ & $\begin{array}{l}\text { constant } \\
\text { stijgend } \\
- \\
-\end{array}$ \\
\hline 17.500 & gemiddeld & stijgend \\
\hline $\begin{array}{r}4.000 \\
4.000 \\
- \\
- \\
- \\
6.000\end{array}$ & $\begin{array}{l}\text { gemiddeld } \\
\text { gemiddeld } \\
\text { laag } \\
\text { gemiddeld } \\
\text { laag } \\
\text { gemiddeld }\end{array}$ & $\begin{array}{l}\text { constant } \\
\text { stijgend } \\
- \\
\text { stijgend } \\
- \\
\text { sterk stijgend }\end{array}$ \\
\hline 10.500 & gemiddeld & stijgend \\
\hline $\begin{array}{r}7.000 \\
- \\
-\end{array}$ & $\begin{array}{l}\text { laag } \\
\text { hoog } \\
\text { laag } \\
\text { laag }\end{array}$ & $\begin{array}{l}\text { constant } \\
\text { stijgend } \\
\text { constant } \\
\text { - }\end{array}$ \\
\hline 2.500 & laag & constant \\
\hline 2.500 & $\begin{array}{l}\text { laag } \\
\text { laag }\end{array}$ & constant \\
\hline - & $\begin{array}{l}\text { laag } \\
\text { laag }\end{array}$ & - \\
\hline - & $\begin{array}{l}\text { laag } \\
\text { gemiddeld } \\
\text { hoog }\end{array}$ & - \\
\hline - & hoog & stijgend \\
\hline 5.000 & laag & dalend \\
\hline 2.500 & $\begin{array}{l}\text { laag } \\
\text { erg laag } \\
\text { laag } \\
\text { gemiddeld } \\
\text { laag } \\
\text { laag }\end{array}$ & $\begin{array}{l}\text { dalend } \\
\text { dalend } \\
\text { - } \\
\text { constant } \\
\text { - } \\
\text { stijgend }\end{array}$ \\
\hline
\end{tabular}


Tabel 1.16 (vervolg)

Aantal werkenden per opleidingstype, Overijssel, gemiddelde 2001-2002

\begin{tabular}{|c|c|c|c|}
\hline Opleidingstype & Aantal & $\begin{array}{l}\text { Overijssel } \\
\text { t.o.v. } \\
\text { Nederland }\end{array}$ & $\begin{array}{l}\text { Trend } \\
1998-2002\end{array}$ \\
\hline WO Medisch & 3.000 & laag & constant \\
\hline WO (dier)geneeskunde & 2.500 & laag & constant \\
\hline WO tandheelkunde & - & laag & - \\
\hline WO farmacie en medische biologie & - & erg laag & - \\
\hline WO Economie & 7.000 & laag & sterk stijgend \\
\hline WO econom(etr)ie & - & erg laag & stijgend \\
\hline WO bedrijfskunde & 2.500 & gemiddeld & sterk stijgend \\
\hline WO accountancy en belastingen & - & laag & stijgend \\
\hline WO rechten en bestuurskunde & 2.500 & laag & constant \\
\hline WO Sociaal-cultureel & 4.500 & laag & stijgend \\
\hline WO sociale wetenschappen & 3.500 & laag & stijgend \\
\hline WO Kunst & - & erg laag & - \\
\hline WO kunstwetenschappen & - & erg laag & - \\
\hline Totaal & 465.500 & - & - \\
\hline
\end{tabular}


Tabel 1.17

Arbeidsmarktpositie potentiële beroepsbevolking naar opleidingstype, Overijssel, gemiddelde 2001-2002

\begin{tabular}{lrrr}
\hline Opleidingstype & Werkzaam & Werkloos & $\begin{array}{r}\text { Niet- } \\
\text { participerend } \\
\%\end{array}$ \\
& $\%$ & $\%$ & Totaal \\
\hline
\end{tabular}

\section{Basisonderwijs}

Basisonderwijs

Basisonderwijs

VMBO

VMBO Theorie

VMBO theorie

VMBO Landbouw en natuurlijke omgeving

VMBO landbouw en natuurlijke omgeving

VMBO Techniek

VMBO bouwtechniek

VMBO installatietechniek

VMBO mechanische techniek

VMBO fijnmechanische techniek

VMBO voertuigentechniek

VMBO elektrotechniek

VMBO grafische techniek

VMBO brood en banket

VMBO transport en logistiek

VMBO Economie

VMBO administratie, handel en mode

VMBO consumptief en levensmiddelentechniek

VMBO Zorg en welzijn

VMBO (uiterlijke) verzorging

VMBO beveiliging

\section{HAVO/VWO, MBO}

VMBO Beveiliging

92.000

HAVO/VWO

HAVO/VWO

MBO Landbouw en natuurlijke omgeving $M B O$ voeding, natuur en milieu $\mathrm{MBO}$ groene ruimte

\section{MBO Techniek}

MBO laboratorium

MBO bouw

MBO grond-, weg- en waterbouw

MBO installatietechniek

MBO werktuigbouw en mechanische techniek

MBO fijnmechanische techniek

MBO motorvoertuigentechniek en tweewielers

MBO vliegtuigtechniek

MBO operationele techniek

MBO elektrotechniek

MBO grafische techniek

MBO procestechniek
15.000

11.500

3.500

7.500

3.000

16.500

4.000 
Tabel 1.17 (vervolg)

Arbeidsmarktpositie potentiële beroepsbevolking naar opleidingstype, Overijssel, gemiddelde 2001-2002

\begin{tabular}{lrrr}
\hline Opleidingstype & Werkzaam & Werkloos & $\begin{array}{r}\text { Niet- } \\
\text { participerend } \\
\%\end{array}$ \\
& $\%$ & $\%$ & Totaal
\end{tabular}

MBO Techniek (vervolg)

MBO brood en banke

MBO levensmiddelentechniek/vleesverwerking

MBO vervoer

MBO Dienstverlening en gezondheidszorg

MBO dokters-, tandarts- en dierenartsassistent

MBO apothekersassistent

$M B O$ verpleging

MBO gezondheidstechniek

MBO sociaal-pedagogisch en welzijn

$M B O$ verzorging

MBO uiterlijke verzorging

MBO horeca

MBO beweging en therapie

MBO Economie

MBO administratie en logistiek

MBO handel

MBO secretariaat

MBO toerisme en recreatie

MBO facilitaire dienstverlening

MBO ICT

MBO geld, bank en belastingen

$\mathrm{MBO}$ verzekeringswezen

MBO Openbare orde en veiligheid

MBO openbare orde en veiligheid

HBO

HBO Onderwijs en tolk en vertaler

HBO lerarenopleiding basisonderwijs

HBO lerarenopleiding talen

$\mathrm{HBO}$ lerarenopleiding natuur en techniek

HBO lerarenopleiding economie en maatschappij

HBO lerarenopleiding lichamelijke opvoeding

HBO lerarenopleiding medisch en verzorging

HBO lerarenopleiding expressie

HBO tolk en vertaler

HBO Landbouw

HBO landbouw en veeteelt

HBO milieukunde en levensmiddelentechnologie

HBO Techniek

HBO laboratorium

HBO bouwkunde

HBO civiele techniek

HBO werktuigbouwkunde

HBO elektrotechniek

HBO informatica

$\mathrm{HBO}$ chemische technologie

HBO vervoer en logistiek

HBO Paramedisch

$\mathrm{HBO}$ verpleegkunde

HBO (fysio)therapie 
Tabel 1.17 (vervolg)

Arbeidsmarktpositie potentiële beroepsbevolking naar opleidingstype, Overijssel, gemiddelde 2001-2002

\begin{tabular}{|c|c|c|c|c|}
\hline Opleidingstype & $\begin{array}{r}\text { Werkzaam } \\
\%\end{array}$ & $\begin{array}{r}\text { Werkloos } \\
\%\end{array}$ & $\begin{array}{r}\text { Niet- } \\
\text { participerend } \\
\%\end{array}$ & Totaal \\
\hline \multicolumn{5}{|l|}{ HBO Paramedisch (vervolg) } \\
\hline HBO voeding & - & - & - & \\
\hline HBO radiologie & - & - & - & - \\
\hline \multicolumn{5}{|l|}{ HBO Economie } \\
\hline HBO accountancy en bedrijfseconomie & 86 & - & - & 4.500 \\
\hline HBO commerciële economie & 90 & - & - & 4.500 \\
\hline HBO toerisme en recreatie & - & - & - & - \\
\hline HBO recht en bestuur & - & - & - & - \\
\hline HBO secretariaat & - & - & - & 2.500 \\
\hline HBO bedrijfskunde & 86 & - & - & 7.000 \\
\hline \multicolumn{5}{|l|}{ HBO Sociaal-cultureel } \\
\hline HBO communicatie en journalistiek & - & - & - & \\
\hline HBO maatschappelijk werk en hulpverlening & 78 & - & - & 8.500 \\
\hline HBO personeel en arbeid & - & - & - & \\
\hline HBO bibliotheek en documentatie & - & - & - & - \\
\hline \multicolumn{5}{|l|}{ HBO Kunst } \\
\hline HBO uitvoerende en beeldende kunsten & 66 & - & - & 4.400 \\
\hline \multicolumn{5}{|l|}{ HBO Openbare orde en veiligheid } \\
\hline HBO openbare orde en veiligheid & - & - & - & - \\
\hline \multicolumn{5}{|l|}{ wo } \\
\hline \multicolumn{5}{|l|}{ WO Letteren en theologie } \\
\hline WO letteren & - & - & - & \\
\hline WO theologie & - & - & - & - \\
\hline \multicolumn{5}{|l|}{ WO Landbouw en milieukunde } \\
\hline WO landbouw en milieukunde & - & - & - & - \\
\hline \multicolumn{5}{|l|}{ WO Techniek } \\
\hline WO wiskunde en natuurwetenschappen & - & - & - & 3.000 \\
\hline WO bouwkunde & - & - & - & - \\
\hline WO civiele techniek & - & - & - & - \\
\hline WO werktuigbouwkunde & - & - & - & - \\
\hline WO elektrotechniek & - & - & - & - \\
\hline WO informatica en bestuurlijke informatiekunde & - & - & - & - \\
\hline \multicolumn{5}{|l|}{ WO Medisch } \\
\hline WO (dier)geneeskunde & 88 & - & - & 3.000 \\
\hline WO tandheelkunde & - & - & - & - \\
\hline WO farmacie en medische biologie & - & - & - & - \\
\hline \multicolumn{5}{|l|}{ WO Economie } \\
\hline WO econom(etr)ie & - & - & - & \\
\hline WO bedrijfskunde & - & - & - & 2.500 \\
\hline WO accountancy en belastingen & - & - & - & \\
\hline WO rechten en bestuurskunde & 100 & - & - & 2.500 \\
\hline \multicolumn{5}{|l|}{ WO Sociaal-cultureel } \\
\hline WO sociale wetenschappen & 87 & - & - & 4.000 \\
\hline \multicolumn{5}{|l|}{ WO Kunst } \\
\hline WO Kunstwetenschappen & - & - & - & - \\
\hline Totaal & 64 & 2 & 34 & 726.500 \\
\hline
\end{tabular}

Bron CBS/ROA 
Tabel 1.18

Percentage jongeren (15-29 jaar) per opleidingssector, Overijssel, gemiddelde 2001-2002

\begin{tabular}{|c|c|c|c|c|}
\hline Opleidingssector & $\%$ & Typering & $\begin{array}{l}\text { Overijssel } \\
\text { t.o.v. } \\
\text { Nederland }\end{array}$ & $\begin{array}{l}\text { Trend } \\
\text { 1998-2002 }\end{array}$ \\
\hline Basisonderwijs & 18 & laag & gemiddeld & dalend \\
\hline VMBO theorie & 35 & erg hoog & gemiddeld & dalend \\
\hline VMBO landbouw en natuurlijke omgeving & - & gemiddeld & gemiddeld & - \\
\hline VMBO techniek & 25 & gemiddeld & hoog & - \\
\hline VMBO economie & 29 & hoog & hoog & dalend \\
\hline VMBO zorg en welzijn & - & laag & gemiddeld & - \\
\hline VMBO beveiliging & - & hoog & erg hoog & - \\
\hline HAVO/NWO & 48 & erg hoog & gemiddeld & constant \\
\hline MBO landbouw en natuurlijke omgeving & 30 & hoog & erg hoog & sterk stijgend \\
\hline MBO techniek & 26 & gemiddeld & hoog & dalend \\
\hline MBO dienstverlening en gezondheidszorg & 30 & hoog & hoog & dalend \\
\hline MBO economie & 30 & hoog & hoog & constant \\
\hline MBO openbare orde en veiligheid & - & laag & gemiddeld & - \\
\hline HBO onderwijs en tolk en vertaler & 16 & laag & hoog & - \\
\hline HBO landbouw & - & laag & laag & - \\
\hline HBO techniek & 26 & gemiddeld & hoog & constant \\
\hline HBO paramedisch & - & hoog & gemiddeld & \\
\hline HBO economie & 24 & gemiddeld & laag & sterk dalend \\
\hline HBO sociaal-cultureel & 24 & gemiddeld & gemiddeld & - \\
\hline HBO kunst & - & laag & laag & - \\
\hline HBO openbare orde en veiligheid & - & gemiddeld & erg hoog & - \\
\hline WO letteren en theologie & - & erg laag & erg laag & - \\
\hline WO landbouw en milieukunde & - & erg laag & erg laag & - \\
\hline WO techniek & - & hoog & gemiddeld & - \\
\hline WO medisch & - & gemiddeld & gemiddeld & - \\
\hline WO economie & - & gemiddeld & laag & - \\
\hline WO sociaal-cultureel & - & gemiddeld & gemiddeld & - \\
\hline WO kunst & - & erg laag & erg laag & - \\
\hline Totaal & 26 & - & - & dalend \\
\hline
\end{tabular}

Bron: CBS/ROA 
Tabel 1.19

Percentage ouderen (50-64) per opleidingssector, Overijssel, gemiddelde 2001-2002

\begin{tabular}{|c|c|c|c|c|}
\hline Opleidingssector & $\%$ & Typering & $\begin{array}{l}\text { Overijssel } \\
\text { t.o.v. } \\
\text { Nederland }\end{array}$ & $\begin{array}{l}\text { Trend } \\
1998-2002\end{array}$ \\
\hline Basisonderwijs & 35 & erg hoog & hoog & stijgend \\
\hline VMBO theorie & 19 & gemiddeld & gemiddeld & constant \\
\hline VMBO landbouw en natuurlijke omgeving & - & hoog & hoog & - \\
\hline VMBO techniek & 18 & gemiddeld & gemiddeld & constant \\
\hline VMBO economie & - & gemiddeld & hoog & - \\
\hline VMBO zorg en welzijn & 25 & gemiddeld & gemiddeld & constant \\
\hline VMBO beveiliging & - & laag & hoog & - \\
\hline HAVO/VWO & 6 & erg laag & laag & constant \\
\hline MBO landbouw en natuurlijke omgeving & - & gemiddeld & erg hoog & - \\
\hline MBO techniek & 22 & gemiddeld & hoog & stijgend \\
\hline MBO dienstverlening en gezondheidszorg & 13 & laag & gemiddeld & sterk stijgend \\
\hline MBO economie & 17 & gemiddeld & gemiddeld & constant \\
\hline MBO openbare orde en veiligheid & - & gemiddeld & hoog & - \\
\hline HBO onderwijs en tolk en vertaler & 26 & hoog & gemiddeld & constant \\
\hline HBO landbouw & - & laag & erg hoog & - \\
\hline HBO techniek & 19 & gemiddeld & gemiddeld & - \\
\hline HBO paramedisch & - & gemiddeld & hoog & - \\
\hline HBO economie & 14 & laag & gemiddeld & constant \\
\hline HBO sociaal-cultureel & - & laag & laag & - \\
\hline HBO kunst & - & hoog & gemiddeld & - \\
\hline HBO openbare orde en veiligheid & - & laag & erg laag & - \\
\hline WO letteren en theologie & - & erg hoog & gemiddeld & - \\
\hline WO landbouw en milieukunde & - & erg laag & laag & - \\
\hline WO techniek & - & hoog & laag & - \\
\hline WO medisch & - & hoog & gemiddeld & - \\
\hline WO economie & - & laag & laag & - \\
\hline WO sociaal-cultureel & - & hoog & laag & - \\
\hline WO kunst & - & - & - & - \\
\hline Totaal & 20 & - & - & stijgend \\
\hline
\end{tabular}

Bron: CBS/ROA 
Tabel 1.20

Percentage vrouwen per opleidingssector, Overijssel, gemiddelde 2001-2002

\begin{tabular}{|c|c|c|c|c|}
\hline Opleidingssector & $\%$ & Typering & $\begin{array}{l}\text { Overijssel } \\
\text { t.o.v. } \\
\text { Nederland }\end{array}$ & $\begin{array}{l}\text { Trend } \\
\text { 1998-2002 }\end{array}$ \\
\hline Basisonderwijs & 31 & gemiddeld & gemiddeld & stijgend \\
\hline VMBO theorie & 48 & hoog & gemiddeld & constant \\
\hline VMBO landbouw en natuurlijke omgeving & - & laag & hoog & - \\
\hline VMBO techniek & 0 & erg laag & laag & - \\
\hline VMBO economie & 43 & gemiddeld & hoog & constant \\
\hline VMBO zorg en welzijn & 95 & erg hoog & hoog & constant \\
\hline VMBO beveiliging & - & laag & gemiddeld & - \\
\hline HAVO/VWO & 40 & gemiddeld & gemiddeld & dalend \\
\hline MBO landbouw en natuurlijke omgeving & - & gemiddeld & erg hoog & - \\
\hline MBO techniek & 4 & erg laag & gemiddeld & constant \\
\hline MBO dienstverlening en gezondheidszorg & 85 & erg hoog & erg hoog & constant \\
\hline MBO economie & 47 & hoog & hoog & stijgend \\
\hline MBO openbare orde en veiligheid & - & laag & gemiddeld & - \\
\hline HBO onderwijs en tolk en vertaler & 63 & hoog & hoog & constant \\
\hline HBO landbouw & - & laag & laag & - \\
\hline HBO techniek & - & gemiddeld & hoog & - \\
\hline HBO paramedisch & 75 & erg hoog & hoog & constant \\
\hline HBO economie & 35 & gemiddeld & gemiddeld & constant \\
\hline HBO sociaal-cultureel & 64 & hoog & gemiddeld & constant \\
\hline HBO kunst & - & gemiddeld & laag & - \\
\hline HBO openbare orde en veiligheid & - & laag & erg hoog & - \\
\hline WO letteren en theologie & - & gemiddeld & laag & - \\
\hline WO landbouw en milieukunde & - & laag & laag & - \\
\hline WO techniek & - & laag & erg laag & - \\
\hline WO medisch & - & gemiddeld & laag & - \\
\hline WO economie & - & gemiddeld & laag & - \\
\hline WO sociaal-cultureel & 61 & hoog & gemiddeld & stijgend \\
\hline WO kunst & - & erg laag & erg laag & - \\
\hline Totaal & 39 & - & - & constant \\
\hline
\end{tabular}

Bron: CBS/ROA 
Tabel 1.21

Percentage flexibel werk per opleidingssector, Overijssel, gemiddelde 2001-2002

\begin{tabular}{|c|c|c|c|c|}
\hline Opleidingssector & $\%$ & Typering & $\begin{array}{l}\text { Overijssel } \\
\text { t.o.v. } \\
\text { Nederland }\end{array}$ & $\begin{array}{l}\text { Trend } \\
1998-2002\end{array}$ \\
\hline Basisonderwijs & 11 & hoog & gemiddeld & dalend \\
\hline VMBO theorie & 18 & hoog & gemiddeld & constant \\
\hline VMBO landbouw en natuurlijke omgeving & - & laag & gemiddeld & - \\
\hline VMBO techniek & 7 & gemiddeld & hoog & - \\
\hline VMBO economie & - & gemiddeld & hoog & - \\
\hline VMBO zorg en welzijn & - & hoog & hoog & - \\
\hline VMBO beveiliging & - & hoog & erg hoog & - \\
\hline HAVO/VWO & 23 & erg hoog & gemiddeld & - \\
\hline MBO landbouw en natuurlijke omgeving & - & gemiddeld & erg hoog & - \\
\hline MBO techniek & 3 & erg laag & gemiddeld & sterk dalend \\
\hline MBO dienstverlening en gezondheidszorg & 7 & gemiddeld & gemiddeld & sterk dalend \\
\hline MBO economie & 7 & gemiddeld & gemiddeld & sterk dalend \\
\hline MBO openbare orde en veiligheid & - & erg laag & gemiddeld & - \\
\hline HBO onderwijs en tolk en vertaler & 7 & gemiddeld & hoog & - \\
\hline HBO landbouw & - & laag & hoog & - \\
\hline HBO techniek & - & laag & laag & - \\
\hline HBO paramedisch & - & gemiddeld & hoog & - \\
\hline HBO economie & 3 & erg laag & laag & - \\
\hline HBO sociaal-cultureel & - & gemiddeld & gemiddeld & - \\
\hline HBO kunst & - & hoog & erg laag & - \\
\hline HBO openbare orde en veiligheid & - & - & - & - \\
\hline WO letteren en theologie & - & gemiddeld & laag & - \\
\hline WO landbouw en milieukunde & - & - & - & - \\
\hline WO techniek & - & laag & laag & - \\
\hline WO medisch & - & laag & erg laag & - \\
\hline WO economie & - & laag & laag & - \\
\hline WO sociaal-cultureel & - & gemiddeld & gemiddeld & - \\
\hline WO kunst & - & - & - & - \\
\hline Totaal & 8 & - & - & dalend \\
\hline
\end{tabular}

Bron: CBS/ROA

Van flexibel werk is sprake bij uitzendkrachten, oproepkrachten, invalkrachten, contracten zonder een vast aantal arbeidsuren en indien geen vast dienstverband is overeengekomen. 
Tabel 1.22

Percentage deeltijdwerk per opleidingssector, Overijssel, gemiddelde 2001-2002

\begin{tabular}{|c|c|c|c|c|}
\hline Opleidingssector & $\%$ & Typering & $\begin{array}{l}\text { Overijssel } \\
\text { t.o.v. } \\
\text { Nederland }\end{array}$ & $\begin{array}{l}\text { Trend } \\
1998-2002\end{array}$ \\
\hline Basisonderwijs & 32 & gemiddeld & gemiddeld & sterk stijgend \\
\hline VMBO theorie & 44 & gemiddeld & gemiddeld & stijgend \\
\hline VMBO landbouw en natuurlijke omgeving & - & laag & laag & - \\
\hline VMBO techniek & 9 & erg laag & erg hoog & constant \\
\hline VMBO economie & 39 & gemiddeld & hoog & constant \\
\hline VMBO zorg en welzijn & 77 & erg hoog & hoog & constant \\
\hline VMBO beveiliging & - & laag & gemiddeld & - \\
\hline HAVO/VWO & 45 & hoog & gemiddeld & stijgend \\
\hline MBO landbouw en natuurlijke omgeving & - & gemiddeld & erg hoog & - \\
\hline MBO techniek & 8 & erg laag & hoog & constant \\
\hline MBO dienstverlening en gezondheidszorg & 69 & erg hoog & erg hoog & stijgend \\
\hline MBO economie & 28 & gemiddeld & hoog & stijgend \\
\hline MBO openbare orde en veiligheid & - & erg laag & gemiddeld & - \\
\hline HBO onderwijs en tolk en vertaler & 51 & hoog & hoog & sterk stijgend \\
\hline HBO landbouw & - & laag & gemiddeld & - \\
\hline HBO techniek & - & gemiddeld & gemiddeld & - \\
\hline HBO paramedisch & 50 & hoog & gemiddeld & constant \\
\hline HBO economie & 17 & gemiddeld & laag & - \\
\hline HBO sociaal-cultureel & 56 & hoog & hoog & stijgend \\
\hline HBO kunst & - & hoog & gemiddeld & - \\
\hline HBO openbare orde en veiligheid & - & laag & laag & - \\
\hline WO letteren en theologie & - & hoog & laag & - \\
\hline WO landbouw en milieukunde & - & gemiddeld & gemiddeld & - \\
\hline WO techniek & - & laag & laag & - \\
\hline WO medisch & - & laag & erg laag & - \\
\hline WO economie & - & gemiddeld & laag & - \\
\hline WO sociaal-cultureel & - & gemiddeld & laag & - \\
\hline WO kunst & - & hoog & erg laag & - \\
\hline Totaal & 32 & - & - & stijgend \\
\hline
\end{tabular}

Bron: CBS/ROA 
Tabel 1.23

Percentage zelfstandigen per opleidingssector, Overijssel, gemiddelde 2001-2002

\begin{tabular}{|c|c|c|c|c|}
\hline Opleidingssector & $\%$ & Typering & $\begin{array}{l}\text { Overijssel } \\
\text { t.o.v. } \\
\text { Nederland }\end{array}$ & $\begin{array}{l}\text { Trend } \\
\text { 1998-2002 }\end{array}$ \\
\hline Basisonderwijs & 9 & gemiddeld & gemiddeld & constant \\
\hline VMBO theorie & 8 & laag & gemiddeld & - \\
\hline VMBO landbouw en natuurlijke omgeving & - & hoog & gemiddeld & - \\
\hline VMBO techniek & 7 & laag & hoog & constant \\
\hline VMBO economie & - & laag & gemiddeld & - \\
\hline VMBO zorg en welzijn & - & hoog & erg hoog & - \\
\hline VMBO beveiliging & - & - & - & - \\
\hline HAVO/NWO & 9 & gemiddeld & gemiddeld & constant \\
\hline MBO landbouw en natuurlijke omgeving & 39 & erg hoog & hoog & - \\
\hline MBO techniek & 9 & gemiddeld & hoog & constant \\
\hline MBO dienstverlening en gezondheidszorg & 7 & laag & gemiddeld & sterk dalend \\
\hline MBO economie & 14 & gemiddeld & hoog & constant \\
\hline MBO openbare orde en veiligheid & - & laag & hoog & - \\
\hline HBO onderwijs en tolk en vertaler & 5 & erg laag & gemiddeld & dalend \\
\hline HBO landbouw & - & hoog & erg hoog & - \\
\hline HBO techniek & - & gemiddeld & hoog & - \\
\hline HBO paramedisch & - & hoog & gemiddeld & - \\
\hline HBO economie & 9 & laag & gemiddeld & - \\
\hline HBO sociaal-cultureel & - & laag & laag & - \\
\hline HBO kunst & - & hoog & laag & - \\
\hline HBO openbare orde en veiligheid & - & gemiddeld & laag & - \\
\hline WO letteren en theologie & - & hoog & laag & - \\
\hline WO landbouw en milieukunde & - & hoog & erg hoog & - \\
\hline WO techniek & - & gemiddeld & gemiddeld & - \\
\hline WO medisch & - & erg hoog & hoog & - \\
\hline WO economie & - & gemiddeld & laag & - \\
\hline WO sociaal-cultureel & - & gemiddeld & laag & - \\
\hline WO kunst & - & erg hoog & laag & - \\
\hline Totaal & 11 & - & - & constant \\
\hline
\end{tabular}

Bron: CBS/ROA 
2 Leerlingen en gediplomeerden in Overijssel 

Tabel 2.1

Aantal leerlingen in het VMBO en MBO per opleidingstype, Overijssel, 2002 en 2003

\begin{tabular}{|c|c|c|c|}
\hline Opleidingstype & $\begin{array}{r}\text { Aantal } \\
2002\end{array}$ & $\begin{array}{r}\text { Aantal } \\
2003\end{array}$ & $\begin{array}{l}\text { Overijssel t.o.v. } \\
\text { Nederland } 2003\end{array}$ \\
\hline \multicolumn{4}{|l|}{ VMBO Theorie } \\
\hline VMBO theorie & 36.840 & 35.770 & gemiddeld \\
\hline \multicolumn{4}{|l|}{ VMBO Landbouw en natuurlijke omgeving } \\
\hline VMBO landbouw en natuurlijke omgeving & 610 & 660 & erg laag \\
\hline \multicolumn{4}{|l|}{ VMBO Techniek } \\
\hline VMBO bouwtechniek & 2.070 & 1.740 & hoog \\
\hline VMBO installatietechniek & 120 & 100 & gemiddeld \\
\hline VMBO mechanische techniek & 640 & 650 & gemiddeld \\
\hline VMBO fijnmechanische techniek & - & - & \\
\hline VMBO voertuigentechniek & 630 & 730 & gemiddeld \\
\hline VMBO elektrotechniek & 1.010 & 900 & gemiddeld \\
\hline VMBO grafische techniek & 140 & 150 & gemiddeld \\
\hline VMBO brood en banket & 20 & 10 & laag \\
\hline VMBO transport en logistiek & 130 & 130 & laag \\
\hline \multicolumn{4}{|l|}{ VMBO Economie } \\
\hline VMBO administratie, handel en mode & 4.070 & 3.670 & gemiddeld \\
\hline VMBO consumptief en levensmiddelentechniek & 560 & 530 & laag \\
\hline \multicolumn{4}{|l|}{ VMBO Zorg en welzijn } \\
\hline VMBO (uiterlijke) verzorging & 4.480 & 4.440 & hoog \\
\hline \multicolumn{4}{|l|}{ VMBO Beveiliging } \\
\hline VMBO beveiliging & 260 & 80 & erg laag \\
\hline \multicolumn{4}{|l|}{ HAVO/VWO } \\
\hline HAVO/VWO & 21.820 & 21.690 & laag \\
\hline \multicolumn{4}{|l|}{ MBO Landbouw } \\
\hline MBO voeding, natuur en milieu & 880 & 890 & laag \\
\hline MBO groene ruimte & 470 & 460 & laag \\
\hline \multicolumn{4}{|l|}{ MBO Techniek } \\
\hline MBO laboratorium & 170 & 160 & erg laag \\
\hline MBO bouw & 3.010 & 2.990 & erg hoog \\
\hline MBO grond-, weg- en waterbouw & 400 & 320 & hoog \\
\hline MBO installatietechniek & 720 & 640 & gemiddeld \\
\hline MBO werktuigbouw en mechanische techniek & 1.160 & 1.110 & gemiddeld \\
\hline MBO fijnmechanische techniek & 50 & 30 & erg laag \\
\hline MBO motorvoertuigentechniek en tweewielers & 1.190 & 1.290 & gemiddeld \\
\hline MBO vliegtuigtechniek & 100 & 90 & erg hoog \\
\hline MBO operationele techniek & 270 & 250 & laag \\
\hline MBO elektrotechniek & 2.070 & 1.870 & hoog \\
\hline MBO grafische techniek & 940 & 900 & gemiddeld \\
\hline MBO procestechniek & 130 & 120 & erg laag \\
\hline MBO brood en banket & 310 & 350 & hoog \\
\hline \multicolumn{4}{|l|}{ MBO levensmiddelentechniek/vleesverwerking } \\
\hline MBO vervoer & 740 & 780 & gemiddeld \\
\hline \multicolumn{4}{|l|}{ MBO Dienstverlening en gezondheidszorg } \\
\hline MBO dokters-, tandarts- en dierenartsassistent & 460 & 450 & hoog \\
\hline MBO apothekersassistent & 160 & 170 & laag \\
\hline MBO verpleging & 1.320 & 1.440 & gemiddeld \\
\hline MBO gezondheidstechniek & 140 & 90 & laag \\
\hline MBO sociaal-pedagogisch en welzijn & 3.920 & 4.180 & gemiddeld \\
\hline MBO verzorging & 3.240 & 3.380 & gemiddeld \\
\hline
\end{tabular}


Tabel 2.1 (vervolg)

Aantal leerlingen in het VMBO en MBO per opleidingstype, Overijssel, 2002 en 2003

\begin{tabular}{lrrl}
\hline Opleidingstype & Aantal & Aantal & Overijssel t.o.v. \\
& 2002 & 2003 & Nederland 2003 \\
& & & \\
\hline MBO Dienstverlening en gezondheidszorg (vervolg) & & & \\
MBO uiterlijke verzorging & 950 & 910 & laag \\
MBO horeca & 1.390 & 1.460 & gemiddeld \\
MBO beweging en therapie & 480 & 760 & gemiddeld \\
MBO Economie & & & \\
MBO administratie en logistiek & 5.150 & 4.170 & hoog \\
MBO handel & 5.000 & 5.110 & hoog \\
MBO secretariaat & 1.050 & 1.000 & gemiddeld \\
MBO toerisme en recreatie & 1.430 & 1.270 & hoog \\
MBO facilitaire dienstverlening & 0 & 60 & hoog \\
MBO ICT & 2.470 & 2.740 & erg hoog \\
MBO geld, bank en belastingen & 50 & - & - \\
MBO verzekeringswezen & 10 & - & - \\
MBO Openbare orde en veiligheid & & & \\
MBO openbare orde en veiligheid & 370 & 540 & gemiddeld \\
\hline
\end{tabular}


Tabel 2.2

Percentage leerlingen (BBL) in het MBO per opleidingstype, Overijssel, 2002 en 2003

\begin{tabular}{|c|c|c|c|}
\hline Opleidingstype & $\begin{array}{r}\% \\
2002\end{array}$ & $\begin{array}{r}\% \\
2003\end{array}$ & $\begin{array}{l}\text { Overijssel t.o.v. } \\
\text { Nederland } 2003\end{array}$ \\
\hline \multicolumn{4}{|l|}{ MBO Landbouw } \\
\hline MBO voeding, natuur en milieu & 20 & 22 & laag \\
\hline MBO groene ruimte & 55 & 53 & gemiddeld \\
\hline \multicolumn{4}{|l|}{ MBO Techniek } \\
\hline \multicolumn{4}{|l|}{ MBO laboratorium } \\
\hline MBO bouw & 64 & 61 & hoog \\
\hline MBO grond-, weg- en waterbouw & 72 & 80 & hoog \\
\hline MBO installatietechniek & 92 & 89 & gemiddeld \\
\hline MBO werktuigbouw en mechanische techniek & 45 & 43 & gemiddeld \\
\hline MBO fijnmechanische techniek & 18 & 15 & laag \\
\hline MBO motorvoertuigentechniek en tweewielers & 71 & 68 & gemiddeld \\
\hline MBO vliegtuigtechniek & 50 & 32 & hoog \\
\hline MBO operationele techniek & 100 & 100 & gemiddeld \\
\hline MBO elektrotechniek & 63 & 55 & hoog \\
\hline MBO grafische techniek & 14 & 10 & erg hoog \\
\hline MBO procestechniek & 85 & 97 & laag \\
\hline MBO brood en banket & 47 & 40 & gemiddeld \\
\hline MBO levensmiddelentechniek/vleesverwerking & - & - & - \\
\hline MBO vervoer & 42 & 40 & gemiddeld \\
\hline \multicolumn{4}{|l|}{ MBO Dienstverlening en gezondheidszorg } \\
\hline MBO dokters-, tandarts- en dierenartsassistent & - & - & - \\
\hline MBO apothekersassistent & - & 4 & erg laag \\
\hline MBO verpleging & 49 & 45 & gemiddeld \\
\hline MBO gezondheidstechniek & 100 & 69 & laag \\
\hline MBO sociaal-pedagogisch en welzijn & 16 & 20 & gemiddeld \\
\hline MBO verzorging & 47 & 46 & gemiddeld \\
\hline MBO uiterlijke verzorging & 48 & 44 & gemiddeld \\
\hline MBO horeca & 39 & 36 & gemiddeld \\
\hline MBO beweging en therapie & - & - & - \\
\hline \multicolumn{4}{|l|}{ MBO Economie } \\
\hline MBO administratie en logistiek & 28 & 19 & hoog \\
\hline MBO handel & 30 & 26 & gemiddeld \\
\hline MBO secretariaat & 6 & 6 & laag \\
\hline MBO toerisme en recreatie & 7 & 7 & hoog \\
\hline MBO facilitaire dienstverlening & 100 & 2 & erg laag \\
\hline MBO ICT & 3 & $4 \overline{1}$ & erg hoog \\
\hline MBO geld, bank en belastingen & - & - & - \\
\hline MBO verzekeringswezen & - & - & - \\
\hline \multicolumn{4}{|l|}{ MBO Openbare orde en veiligheid } \\
\hline MBO openbare orde en veiligheid & 6 & 13 & erg laag \\
\hline
\end{tabular}


Tabel 2.3

Percentage vrouwelijke leerlingen in het VMBO en MBO per opleidingstype, Overijssel, 2002 en 2003

\begin{tabular}{|c|c|c|c|}
\hline Opleidingstype & $\begin{array}{r}\% \\
2002\end{array}$ & $\begin{array}{r}\% \\
2003\end{array}$ & $\begin{array}{l}\text { Typering t.o.v. } \\
\text { Nederland } 2003\end{array}$ \\
\hline \multicolumn{4}{|l|}{ VMBO Theorie } \\
\hline VMBO theorie & 48 & 49 & gemiddeld \\
\hline \multicolumn{4}{|l|}{ VMBO Landbouw en natuurlijke omgeving } \\
\hline VMBO landbouw en natuurlijke omgeving & 33 & 37 & laag \\
\hline \multicolumn{4}{|l|}{ VMBO Techniek } \\
\hline VMBO bouwtechniek & 4 & 4 & gemiddeld \\
\hline VMBO installatietechniek & 0 & 1 & hoog \\
\hline VMBO mechanische techniek & 1 & 10 & erg hoog \\
\hline VMBO fijnmechanische techniek & - & - & - \\
\hline VMBO voertuigentechniek & 1 & 1 & erg laag \\
\hline VMBO elektrotechniek & 3 & 6 & erg hoog \\
\hline VMBO grafische techniek & 17 & 19 & laag \\
\hline VMBO brood en banket & 16 & 27 & gemiddeld \\
\hline VMBO transport en logistiek & 3 & 1 & erg laag \\
\hline \multicolumn{4}{|l|}{ VMBO Economie } \\
\hline VMBO administratie, handel en mode & 44 & 44 & gemiddeld \\
\hline VMBO consumptief en levensmiddelentechniek & 33 & 28 & laag \\
\hline \multicolumn{4}{|l|}{ VMBO Zorg en welzijn } \\
\hline VMBO (uiterlijke) verzorging & 91 & 89 & gemiddeld \\
\hline \multicolumn{4}{|l|}{ VMBO Beveiliging } \\
\hline VMBO beveiliging & 27 & 25 & hoog \\
\hline \multicolumn{4}{|l|}{ HAVO/VWO } \\
\hline HAVO/VWO & 54 & 54 & gemiddeld \\
\hline \multicolumn{4}{|l|}{ MBO Landbouw } \\
\hline MBO voeding, natuur en milieu & 61 & 63 & gemiddeld \\
\hline MBO groene ruimte & 5 & 4 & laag \\
\hline \multicolumn{4}{|l|}{ MBO Techniek } \\
\hline MBO laboratorium & 45 & 41 & gemiddeld \\
\hline MBO bouw & 9 & 10 & hoog \\
\hline MBO grond-, weg- en waterbouw & 0 & 0 & laag \\
\hline MBO installatietechniek & 1 & 0 & erg laag \\
\hline MBO werktuigbouw en mechanische techniek & 1 & 0 & erg laag \\
\hline MBO fijnmechanische techniek & 22 & 21 & erg laag \\
\hline MBO motorvoertuigentechniek en tweewielers & 0 & 1 & laag \\
\hline MBO vliegtuigtechniek & 1 & 3 & erg hoog \\
\hline MBO operationele techniek & 6 & 7 & hoog \\
\hline MBO elektrotechniek & 1 & 1 & laag \\
\hline MBO grafische techniek & 27 & 24 & laag \\
\hline MBO procestechniek & 1 & 2 & laag \\
\hline MBO brood en banket & 15 & 14 & laag \\
\hline MBO levensmiddelentechniek/vleesverwerking & - & - & - \\
\hline MBO vervoer & 18 & 20 & hoog \\
\hline \multicolumn{4}{|l|}{ MBO Dienstverlening en gezondheidszorg } \\
\hline MBO dokters-, tandarts- en dierenartsassistent & 100 & 99 & gemiddeld \\
\hline MBO apothekersassistent & 99 & 99 & gemiddeld \\
\hline MBO verpleging & 87 & 85 & gemiddeld \\
\hline MBO gezondheidstechniek & 57 & 44 & hoog \\
\hline MBO sociaal-pedagogisch en welzijn & 84 & 83 & gemiddeld \\
\hline
\end{tabular}


Tabel 2.3 (vervolg)

Percentage vrouwelijke leerlingen in het VMBO en MBO per opleidingstype, Overijssel, 2001 en 2002

\begin{tabular}{|c|c|c|c|}
\hline Opleidingstype & $\begin{array}{r}\% \\
2001\end{array}$ & $\begin{array}{r}\% \\
2002\end{array}$ & $\begin{array}{l}\text { Typering t.o.v. } \\
\text { Nederland } 2002\end{array}$ \\
\hline \multicolumn{4}{|c|}{ MBO Dienstverlening en gezondheidszorg (vervolg) } \\
\hline MBO verzorging & 93 & 93 & gemiddeld \\
\hline MBO uiterlijke verzorging & 99 & 99 & gemiddeld \\
\hline MBO horeca & 39 & 40 & gemiddeld \\
\hline MBO beweging en therapie & 37 & 34 & gemiddeld \\
\hline \multicolumn{4}{|l|}{ MBO Economie } \\
\hline MBO administratie en logistiek & 56 & 47 & hoog \\
\hline MBO handel & 54 & 54 & hoog \\
\hline MBO secretariaat & 96 & 97 & gemiddeld \\
\hline MBO toerisme en recreatie & 75 & 79 & gemiddeld \\
\hline MBO facilitaire dienstverlening & 0 & 45 & gemiddeld \\
\hline MBO ICT & 6 & 19 & erg hoog \\
\hline MBO geld, bank en belastingen & 50 & - & - \\
\hline MBO verzekeringswezen & 40 & - & - \\
\hline \multicolumn{4}{|l|}{ MBO Openbare orde en veiligheid } \\
\hline MBO openbare orde en veiligheid & 33 & 25 & hoog \\
\hline
\end{tabular}


Tabel 2.4

Aantal gediplomeerden in het VMBO en MBO per opleidingstype, Overijssel, 2002 en 2003

\begin{tabular}{|c|c|c|c|}
\hline Opleidingstype & $\begin{array}{r}\text { Aantal } \\
2002\end{array}$ & $\begin{array}{r}\text { Aantal } \\
2003\end{array}$ & $\begin{array}{l}\text { Overijssel t.o.v. } \\
\text { Nederland } 2003\end{array}$ \\
\hline \multicolumn{4}{|l|}{ VMBO Theorie } \\
\hline VMBO theorie & 4.060 & 2.760 & gemiddeld \\
\hline \multicolumn{4}{|l|}{ VMBO Landbouw en natuurlijke omgeving } \\
\hline VMBO landbouw en natuurlijke omgeving & 260 & 250 & erg laag \\
\hline \multicolumn{4}{|l|}{ VMBO Techniek } \\
\hline VMBO bouwtechniek & 770 & 820 & hoog \\
\hline VMBO installatietechniek & 60 & 20 & erg laag \\
\hline VMBO mechanische techniek & 380 & 270 & gemiddeld \\
\hline VMBO fijnmechanische techniek & - & - & - \\
\hline VMBO voertuigentechniek & 230 & 250 & laag \\
\hline VMBO elektrotechniek & 440 & 470 & hoog \\
\hline VMBO grafische techniek & 30 & 50 & laag \\
\hline VMBO brood en banket & 40 & 10 & gemiddeld \\
\hline VMBO transport en logistiek & 60 & 70 & gemiddeld \\
\hline \multicolumn{4}{|l|}{ VMBO Economie } \\
\hline VMBO administratie, handel en mode & 1.050 & 1.450 & gemiddeld \\
\hline VMBO consumptief en levensmiddelentechniek & 210 & 240 & laag \\
\hline \multicolumn{4}{|l|}{ VMBO Zorg en welzijn } \\
\hline VMBO (uiterlijke) verzorging & 1.500 & 1.960 & hoog \\
\hline \multicolumn{4}{|l|}{ VMBO Beveiliging } \\
\hline VMBO beveiliging & 380 & 170 & laag \\
\hline \multicolumn{4}{|l|}{ HAVO/VWO } \\
\hline HAVO/VWO & 4.730 & 4.580 & gemiddeld \\
\hline \multicolumn{4}{|l|}{ MBO Landbouw } \\
\hline MBO voeding, natuur en milieu & 170 & 180 & laag \\
\hline MBO groene ruimte & 140 & 110 & gemiddeld \\
\hline \multicolumn{4}{|l|}{ MBO Techniek } \\
\hline MBO laboratorium & 80 & 40 & laag \\
\hline MBO bouw & 1.110 & 1.020 & erg hoog \\
\hline MBO grond-, weg- en waterbouw & 200 & 160 & hoog \\
\hline MBO installatietechniek & 290 & 300 & hoog \\
\hline MBO werktuigbouw en mechanische techniek & 380 & 350 & gemiddeld \\
\hline MBO fijnmechanische techniek & 30 & 20 & erg laag \\
\hline MBO motorvoertuigentechniek en tweewielers & 410 & 370 & gemiddeld \\
\hline MBO vliegtuigtechniek & 10 & 10 & gemiddeld \\
\hline MBO operationele techniek & 70 & 40 & gemiddeld \\
\hline MBO elektrotechniek & 530 & 520 & hoog \\
\hline MBO grafische techniek & 260 & 220 & erg hoog \\
\hline MBO procestechniek & 30 & 20 & erg laag \\
\hline MBO brood en banket & 80 & 60 & gemiddeld \\
\hline \multicolumn{4}{|l|}{ MBO levensmiddelentechniek/vleesverwerking } \\
\hline MBO vervoer & 220 & 170 & laag \\
\hline \multicolumn{4}{|l|}{ MBO Dienstverlening en gezondheidszorg } \\
\hline MBO dokters-, tandarts- en dierenartsassistent & 100 & 160 & hoog \\
\hline MBO apothekersassistent & 60 & 50 & laag \\
\hline MBO verpleging & 370 & 340 & gemiddeld \\
\hline MBO gezondheidstechniek & 70 & 50 & gemiddeld \\
\hline MBO sociaal-pedagogisch en welzijn & 700 & 1.030 & gemiddeld \\
\hline $\mathrm{MBO}$ verzorging & 1.270 & 1.270 & gemiddeld \\
\hline
\end{tabular}


Tabel 2.4 (vervolg)

Aantal gediplomeerden in het VMBO en MBO per opleidingstype, Overijssel, 2002 en 2003

\begin{tabular}{lrrl}
\hline Opleidingstype & Aantal & Aantal & $\begin{array}{l}\text { Overijssel t.o.v. } \\
\text { Nederland 2003 }\end{array}$ \\
& 2002 & 2003 & \\
\hline MBO Dienstverlening en gezondheidszorg (vervolg) & & & \\
MBO uiterlijke verzorging & 320 & 330 & gemiddeld \\
MBO horeca & 370 & 390 & gemiddeld \\
MBO beweging en therapie & - & - & - \\
MBO Economie & & & \\
MBO administratie en logistiek & 1.040 & 780 & gemiddeld \\
MBO handel & 1.620 & 1.660 & hoog \\
MBO secretariaat & 300 & 260 & gemiddeld \\
MBO toerisme en recreatie & 280 & 290 & erg hoog \\
MBO facilitaire dienstverlening & 620 & 680 & hoog \\
MBO ICT & 120 & 30 & laag \\
MBO geld, bank en belastingen & 40 & 0 & erg laag \\
MBO verzekeringswezen & & & \\
MBO Openbare orde en veiligheid & 20 & 260 & erg hoog \\
MBO openbare orde en veiligheid & & & \\
\hline
\end{tabular}


Tabel 2.6

Percentage vrouwelijke gediplomeerden in het VMBO en MBO per opleidingstype, Overijssel, 2002 en 2003

\begin{tabular}{|c|c|c|c|}
\hline Opleidingstype & $\begin{array}{r}\% \\
2002\end{array}$ & $\begin{array}{r}\% \\
2003\end{array}$ & $\begin{array}{l}\text { Typering t.o.v. } \\
\text { Nederland } 2003\end{array}$ \\
\hline \multicolumn{4}{|l|}{ VMBO Theorie } \\
\hline VMBO theorie & 51 & 48 & gemiddeld \\
\hline \multicolumn{4}{|l|}{ VMBO Landbouw en natuurlijke omgeving } \\
\hline VMBO landbouw en natuurlijke omgeving & 32 & 31 & laag \\
\hline \multicolumn{4}{|l|}{ VMBO Techniek } \\
\hline VMBO bouwtechniek & 0 & 1 & laag \\
\hline VMBO installatietechniek & 0 & 0 & erg laag \\
\hline VMBO mechanische techniek & 0 & 1 & laag \\
\hline VMBO fijnmechanische techniek & - & - & - \\
\hline VMBO voertuigentechniek & 0 & 1 & hoog \\
\hline VMBO elektrotechniek & 2 & 1 & gemiddeld \\
\hline VMBO grafische techniek & 0 & 18 & laag \\
\hline VMBO brood en banket & 30 & 0 & erg laag \\
\hline VMBO transport en logistiek & 0 & 1 & laag \\
\hline \multicolumn{4}{|l|}{ VMBO Economie } \\
\hline VMBO administratie, handel en mode & 55 & 46 & gemiddeld \\
\hline VMBO consumptief en levensmiddelentechniek & 23 & 37 & gemiddeld \\
\hline \multicolumn{4}{|l|}{ VMBO Zorg en welzijn } \\
\hline VMBO (uiterlijke) verzorging & 91 & 91 & gemiddeld \\
\hline \multicolumn{4}{|l|}{ VMBO Beveiliging } \\
\hline VMBO beveiliging & 27 & 28 & hoog \\
\hline \multicolumn{4}{|l|}{ HAVONWWO } \\
\hline HAVO/VWO & 54 & 57 & hoog \\
\hline \multicolumn{4}{|l|}{ MBO Landbouw } \\
\hline MBO voeding, natuur en milieu & 53 & 56 & hoog \\
\hline MBO groene ruimte & 6 & 5 & laag \\
\hline \multicolumn{4}{|l|}{ MBO Techniek } \\
\hline MBO laboratorium & 48 & 55 & hoog \\
\hline MBO bouw & 6 & 5 & erg hoog \\
\hline MBO grond-, weg- en waterbouw & 0 & 1 & erg hoog \\
\hline MBO installatietechniek & 1 & 0 & laag \\
\hline MBO werktuigbouw en mechanische techniek & 1 & 2 & erg hoog \\
\hline MBO fijnmechanische techniek & 3 & 17 & laag \\
\hline MBO motorvoertuigentechniek en tweewielers & 1 & 0 & erg laag \\
\hline MBO vliegtuigtechniek & 0 & 0 & erg laag \\
\hline MBO operationele techniek & 12 & 10 & erg hoog \\
\hline MBO elektrotechniek & 1 & 1 & gemiddeld \\
\hline MBO grafische techniek & 30 & 27 & gemiddeld \\
\hline MBO procestechniek & 11 & 0 & erg laag \\
\hline MBO brood en banket & 17 & 23 & gemiddeld \\
\hline \multicolumn{4}{|l|}{ MBO levensmiddelentechniek/vleesverwerking } \\
\hline MBO vervoer & 8 & 14 & hoog \\
\hline \multicolumn{4}{|l|}{ MBO Dienstverlening en gezondheidszorg } \\
\hline MBO dokters-, tandarts- en dierenartsassistent & 100 & 100 & gemiddeld \\
\hline MBO apothekersassistent & 100 & 100 & hoog \\
\hline MBO verpleging & 87 & 90 & gemiddeld \\
\hline MBO gezondheidstechniek & 61 & 70 & erg hoog \\
\hline MBO sociaal-pedagogisch en welzijn & 87 & 87 & gemiddeld \\
\hline
\end{tabular}


Tabel 2.6 (vervolg)

Percentage vrouwelijke gediplomeerden in het VMBO en MBO per opleidingstype, Overijssel, 2002 en 2003

\begin{tabular}{lrrl}
\hline Opleidingstype & $\%$ & $\begin{array}{r}\% \\
\text { M }\end{array}$ & $\begin{array}{l}\text { Typering t.o.v. } \\
\text { Nederland 2003 }\end{array}$ \\
& 2002 & 2003 & \\
\hline MBO Dienstverlening en gezondheidszorg (vervolg) & & & \\
$\quad$ MBO verzorging & 93 & 94 & gemiddeld \\
MBO uiterlijke verzorging & 99 & 100 & gemiddeld \\
MBO horeca & 33 & 37 & gemiddeld \\
MBO beweging en therapie & - & - & - \\
MBO Economie & & & \\
MBO administratie en logistiek & 30 & 43 & gemiddeld \\
MBO handel & 55 & 52 & hoog \\
MBO secretariaat & 99 & 100 & gemiddeld \\
MBO toerisme en recreatie & 80 & 82 & gemiddeld \\
MBO facilitaire dienstverlening & - & - & - \\
MBO ICT & 4 & 3 & laag \\
MBO geld, bank en belastingen & 52 & 41 & gemiddeld \\
MBO verzekeringswezen & 58 & 50 & hoog \\
MBO Openbare orde en veiligheid & & & \\
MBO openbare orde en veiligheid & 47 & 36 & hoog \\
\hline
\end{tabular}


3 Actuele discrepanties op de Overijsselse arbeidsmarkt 

Tabel 3.1

Openstaande vacatures per bedrijfssector, Overijssel, april 2004

\begin{tabular}{|c|c|c|c|}
\hline \multirow[t]{2}{*}{ Bedrijfssector } & Aantal & $\begin{array}{r}\text { Vacature- } \\
\text { graad }\end{array}$ & Typering \\
\hline & \multicolumn{3}{|c|}{$\%$} \\
\hline Landbouw en visserij & 140 & 5 & laag \\
\hline Voeding & 400 & 41 & hoog \\
\hline Chemie & 40 & 4 & laag \\
\hline Metaal en elektrotechniek & 250 & 8 & gemiddeld \\
\hline Overige industrie & 190 & 6 & gemiddeld \\
\hline Energie & - & 2 & erg laag \\
\hline Bouw en onroerend goed & 640 & 15 & gemiddeld \\
\hline Handel en reparatie & 1.000 & 11 & gemiddeld \\
\hline Horeca en zakelijke dienstverlening & 290 & 11 & gemiddeld \\
\hline Transport en communicatie & 290 & 28 & hoog \\
\hline Bank- en verzekeringswezen & 3.740 & 46 & erg hoog \\
\hline Kwartaire diensten & 930 & 12 & gemiddeld \\
\hline Overheid en onderwijs & 590 & 10 & gemiddeld \\
\hline Totaal & 8.510 & 17 & - \\
\hline
\end{tabular}

Bron: CBS/CWI/Etil/ROA 
Tabel 3.2

Openstaande vacatures per beroepssegment, Overijssel, april 2004

\begin{tabular}{|c|c|c|c|}
\hline Beroepssegment & Aantal & $\begin{array}{r}\text { Vacature- } \\
\text { graad }\end{array}$ & Typering \\
\hline Elementaire beroepen & 890 & 23 & hoog \\
\hline Lagere niet-specialistische beroepen & - & - & - \\
\hline Lagere docenten sportvakken & - & - & - $\quad$ \\
\hline Lagere agrarische beroepen & 100 & 10 & gemiddeld \\
\hline Lagere wiskundige, natuurwetenschappelijke beroepen & - & - & - \\
\hline Lagere technische beroepen & 1.350 & 31 & hoog \\
\hline Lagere transportberoepen & 170 & 10 & laag \\
\hline Lagere (para)medische beroepen & - & - & - \\
\hline Lagere administratieve, commerciële beroepen e.d. & 660 & 16 & gemiddeld \\
\hline Lagere beveiligingsberoepen & 520 & 120 & erg hoog \\
\hline Lagere verzorgende beroepen & 300 & 19 & hoog \\
\hline Middelbare docenten transport-, sportvakken & 50 & 42 & erg hoog \\
\hline Middelbare agrarische beroepen & 20 & 1 & erg laag \\
\hline Middelbare wiskundige, natuurwetenschappelijke beroepen & - & - & - \\
\hline Middelbare technische beroepen & 1.170 & 20 & hoog \\
\hline Middelbare transportberoepen e.d. & 10 & 4 & laag \\
\hline Middelbare (para)medische beroepen & 150 & 7 & laag \\
\hline Middelbare administratieve, commerciële beroepen e.d. & 1.290 & 18 & gemiddeld \\
\hline Middelbare juridische, bestuurlijke, beveiligingsberoepen & - & - & - \\
\hline Middelbare taalkundige, culturele beroepen & 30 & 11 & gemiddeld \\
\hline Middelbare beroepen m.b.t. gedrag en maatschappij & 80 & 18 & gemiddeld \\
\hline Middelbare verzorgende beroepen e.d. & 340 & 19 & hoog \\
\hline Hogere pedagogische beroepen & 70 & 3 & erg laag \\
\hline Hogere landbouwkundige beroepen & 10 & 8 & laag \\
\hline Hogere wiskundige, natuurwetenschappelijke beroepen & - & - & \\
\hline Hogere technische beroepen & 320 & 31 & hoog \\
\hline Hogere transportberoepen & - & - & - \\
\hline Hogere (para)medische beroepen & 90 & 10 & laag \\
\hline Hogere administratieve, commerciële, economische beroepen & 430 & 15 & gemiddeld \\
\hline Hogere juridische, bestuurlijke, beveiligingsberoepen & 20 & 15 & gemiddeld \\
\hline Hogere taalkundige, culturele beroepen & 40 & 17 & gemiddeld \\
\hline Hogere beroepen mbt gedrag en maatschappij e.d. & 150 & 18 & gemiddeld \\
\hline Hogere verzorgende beroepen & 20 & 175 & erg hoog \\
\hline Managers (HBO werk- en denkniveau) e.d. & 50 & 14 & gemiddeld \\
\hline Wetenschappelijke pedagogische beroepen & - & - & - \\
\hline Wetenschappelijke landbouwkundige beroepen & - & - & - \\
\hline Wetenschappelijke wiskundige, natuurwetenschappelijke beroepen & - & - & - \\
\hline Wetenschappelijke technische beroepen & 60 & 27 & hoog \\
\hline Wetenschappelijke (para)medische beroepen e.d. & 20 & 5 & laag \\
\hline Wetenschappelijke economische, administratieve beroepen e.d. & - & - & - \\
\hline Wetenschappelijke, juridische, bestuurlijke beroepen & 30 & 11 & gemiddeld \\
\hline Wetenschappelijke beroepen m.b.t. gedrag en maatschappij e.d. & 20 & 10 & laag \\
\hline Managers (wetenschappelijke werk- en denkniveau) & - & 0 & erg laag \\
\hline Totaal & 8.510 & 17 & gemiddeld \\
\hline
\end{tabular}

Bron: CBS/CWI/Etil/ROA 
Tabel 3.3

Niet-werkende werkzoekenden per beroepssegment, Overijssel, april 2004

Lagere niet-specialistische beroepen $\quad 30$

Lagere docenten sportvakken $\quad 20$

$\begin{array}{lr}\text { Lagere agrarische beroepen } & 410\end{array}$

Lagere wiskundige, natuurwetenschappelijke beroepen $\quad 20$

$\begin{array}{ll}\text { Lagere technische beroepen } & 4.020\end{array}$

$\begin{array}{ll}\text { Lagere transportberoepen } & 1.990\end{array}$

Lagere (para)medische beroepen $\quad 10$

Lagere administratieve, commerciële beroepen e.d. $\quad 5.710$

Lagere beveiligingsberoepen $r .710$

$\begin{array}{lr}\text { Lagere verzorgende beroepen } & 1.940\end{array}$

Middelbare docenten transport-, sportvakken $\quad 130$

$\begin{array}{lr}\text { Middelbare agrarische beroepen } & 170\end{array}$

Middelbare wiskundige, natuurwetenschappelijke beroepen $\quad 50$

$\begin{array}{lr}\text { Middelbare technische beroepen } & 3.810\end{array}$

$\begin{array}{lr}\text { Middelbare transportberoepen e.d. } & 150\end{array}$

Middelbare (para)medische beroepen $\quad 450$

Middelbare administratieve, commerciële beroepen e.d. $\quad 5.570$

Middelbare juridische, bestuurlijke, beveiligingsberoepen $\quad 40$

$\begin{array}{ll}\text { Middelbare taalkundige, culturele beroepen } & 200\end{array}$

Middelbare beroepen m.b.t. gedrag en maatschappij $\quad 660$

$\begin{array}{lr}\text { Middelbare verzorgende beroepen e.d. } & 1.360\end{array}$

$\begin{array}{ll}\text { Hogere pedagogische beroepen } & 650\end{array}$

$\begin{array}{lr}\text { Hogere landbouwkundige beroepen } & 40\end{array}$

Hogere wiskundige, natuurwetenschappelijke beroepen $\quad 40$

$\begin{array}{ll}\text { Hogere technische beroepen } & 630\end{array}$

$\begin{array}{lr}\text { Hogere transportberoepen } & 20\end{array}$

$\begin{array}{lr}\text { Hogere (para)medische beroepen } & 150\end{array}$

Hogere administratieve, commerciële, economische beroepen $\quad 1.510$

$\begin{array}{lr}\text { Hogere juridische, bestuurlijke, beveiligingsberoepen } & 10\end{array}$

Hogere taalkundige, culturele beroepen $\quad 430$

Hogere beroepen m.b.t. gedrag en maatschappij e.d. $\quad 730$

$\begin{array}{lr}\text { Hogere verzorgende beroepen } & 60\end{array}$

$\begin{array}{lr}\text { Managers (HBO werk- en denkniveau) e.d. } & 180\end{array}$

$\begin{array}{lr}\text { Wetenschappelijke pedagogische beroepen } & 160\end{array}$

Wetenschappelijke landbouwkundige beroepen $\quad 30$

Wetenschappelijke wiskundige, natuurwetenschappelijke beroepen $\quad 50$

$\begin{array}{lr}\text { Wetenschappelijke technische beroepen } & 220\end{array}$

Wetenschappelijke (para)medische beroepen e.d. $\quad 80$

Wetenschappelijke economische, administratieve beroepen e.d. 200

$\begin{array}{ll}\text { Wetenschappelijke, juridische, bestuurlijke beroepen } & 140\end{array}$

$\begin{array}{ll}\text { Wetenschappelijke beroepen mbt gedrag en maatschappij e.d. } & 70\end{array}$

$\begin{array}{ll}\text { Managers (wetenschappelijke werk- en denkniveau) } & 90\end{array}$

Totaal $\quad 45.550$

Bron: CBS/CWI/Etil/ROA 
Tabel 3.4

Niet-werkende werkzoekenden per beroepssegment en bemiddelingsfase, Overijssel, april 2004

\begin{tabular}{|c|c|c|c|c|}
\hline Beroepssegment & $\begin{array}{r}\text { Fase } 1 \\
\%\end{array}$ & Typering & $\begin{array}{c}\text { Fase } \\
2+3 \\
\%\end{array}$ & Typering \\
\hline Elementaire beroepen & 17 & laag & 32 & laag \\
\hline Lagere niet-specialistische beroepen & 27 & gemiddeld & 40 & gemiddeld \\
\hline Lagere docenten sportvakken & 21 & gemiddeld & 38 & gemiddeld \\
\hline Lagere agrarische beroepen & 21 & gemiddeld & 24 & erg laag \\
\hline Lagere wiskundige, natuurwetenschappelijke beroepen & 17 & laag & 45 & hoog \\
\hline Lagere technische beroepen & 31 & hoog & 33 & laag \\
\hline Lagere transportberoepen & 23 & gemiddeld & 41 & gemiddeld \\
\hline Lagere (para)medische beroepen & 9 & erg laag & 73 & erg hoog \\
\hline Lagere administratieve, commerciële beroepen e.d. & 29 & hoog & 42 & gemiddeld \\
\hline Lagere beveiligingsberoepen & 20 & laag & 43 & gemiddeld \\
\hline Lagere verzorgende beroepen & 14 & erg laag & 32 & laag \\
\hline Middelbare docenten transport-, sportvakken & 24 & gemiddeld & 36 & laag \\
\hline Middelbare agrarische beroepen & 20 & gemiddeld & 24 & erg laag \\
\hline Middelbare wiskundige, natuurwetenschappelijke beroepen & 34 & erg hoog & 21 & erg laag \\
\hline Middelbare technische beroepen & 29 & hoog & 35 & laag \\
\hline Middelbare transportberoepen e.d. & 17 & laag & 25 & erg laag \\
\hline Middelbare (para)medische beroepen & 21 & gemiddeld & 44 & gemiddeld \\
\hline Middelbare administratieve, commerciële beroepen e.d. & 27 & gemiddeld & 42 & gemiddeld \\
\hline Middelbare juridische, bestuurlijke, beveiligingsberoepen & 27 & gemiddeld & 34 & laag \\
\hline Middelbare taalkundige, culturele beroepen & 25 & gemiddeld & 49 & hoog \\
\hline Middelbare beroepen m.b.t. gedrag en maatschappij & 25 & gemiddeld & 49 & hoog \\
\hline Middelbare verzorgende beroepen e.d. & 19 & laag & 38 & gemiddeld \\
\hline Hogere pedagogische beroepen & 15 & erg laag & 42 & gemiddeld \\
\hline Hogere landbouwkundige beroepen & 44 & erg hoog & 35 & laag \\
\hline Hogere wiskundige, natuurwetenschappelijke beroepen & 28 & gemiddeld & 55 & erg hoog \\
\hline Hogere technische beroepen & 31 & hoog & 44 & gemiddeld \\
\hline Hogere transportberoepen & 28 & hoog & 40 & gemiddeld \\
\hline Hogere (para)medische beroepen & 29 & hoog & 42 & gemiddeld \\
\hline Hogere administratieve, commerciële, economische beroepen & 31 & hoog & 45 & hoog \\
\hline Hogere juridische, bestuurlijke, beveiligingsberoepen & 36 & erg hoog & 47 & hoog \\
\hline Hogere taalkundige, culturele beroepen & 15 & laag & 30 & laag \\
\hline Hogere beroepen mbt gedrag en maatschappij e.d. & 30 & hoog & 43 & gemiddeld \\
\hline Hogere verzorgende beroepen & 27 & gemiddeld & 41 & gemiddeld \\
\hline Managers (HBO werk- en denkniveau) e.d. & 19 & laag & 41 & gemiddeld \\
\hline Wetenschappelijke pedagogische beroepen & 23 & gemiddeld & 51 & erg hoog \\
\hline Wetenschappelijke landbouwkundige beroepen & 17 & laag & 69 & erg hoog \\
\hline Wetenschappelijke wiskundige, natuurwetenschappelijke beroepen & 20 & gemiddeld & 36 & gemiddeld \\
\hline Wetenschappelijke technische beroepen & 27 & gemiddeld & 47 & hoog \\
\hline Wetenschappelijke (para)medische beroepen e.d. & 18 & laag & 44 & hoog \\
\hline Wetenschappelijke economische, administratieve beroepen e.d. & 25 & gemiddeld & 50 & hoog \\
\hline Wetenschappelijke, juridische, bestuurlijke beroepen & 36 & erg hoog & 43 & gemiddeld \\
\hline Wetenschappelijke beroepen m.b.t. gedrag en matschappij e.d. & 28 & hoog & 49 & hoog \\
\hline Managers (wetenschappelijke werk- en denkniveau) & 7 & erg laag & 26 & laag \\
\hline Totaal & 25 & - & 37 & \\
\hline
\end{tabular}

Bron: CBS/CWI/Etil/ROA 
Tabel 3.5

Kenmerken niet-werkende werkzoekenden per beroepssegment, Overijssel, april 2004

\begin{tabular}{|c|c|c|c|}
\hline Beroepssegment & $\begin{array}{r}\text { Vrouw } \\
\%\end{array}$ & $\begin{array}{r}\text { Jong } \\
(15-29) \\
\%\end{array}$ & $\begin{array}{r}\text { Oud } \\
(50-64) \\
\%\end{array}$ \\
\hline Elementaire beroepen & 47 & 30 & 21 \\
\hline Lagere niet-specialistische beroepen & 47 & 29 & 18 \\
\hline Lagere docenten sportvakken & 94 & 27 & 44 \\
\hline Lagere agrarische beroepen & 25 & 26 & 23 \\
\hline Lagere wiskundige, natuurwetenschappelijke beroepen & 53 & 24 & 13 \\
\hline Lagere technische beroepen & 10 & 26 & 28 \\
\hline Lagere transportberoepen & 10 & 18 & 30 \\
\hline Lagere (para)medische beroepen & 77 & 0 & 26 \\
\hline Lagere administratieve, commerciële beroepen e.d. & 85 & 35 & 19 \\
\hline Lagere beveiligingsberoepen & 23 & 35 & 20 \\
\hline Lagere verzorgende beroepen & 86 & 29 & 21 \\
\hline Middelbare docenten transport-, sportvakken & 33 & 25 & 29 \\
\hline Middelbare agrarische beroepen & 21 & 21 & 36 \\
\hline Middelbare wiskundige, natuurwetenschappelijke beroepen & 63 & 47 & 21 \\
\hline Middelbare technische beroepen & 13 & 19 & 33 \\
\hline Middelbare transportberoepen e.d. & 15 & 13 & 42 \\
\hline Middelbare (para)medische beroepen & 89 & 22 & 27 \\
\hline Middelbare administratieve, commerciële beroepen e.d. & 54 & 23 & 25 \\
\hline Middelbare juridische, bestuurlijke, beveiligingsberoepen & 43 & 32 & 18 \\
\hline Middelbare taalkundige, culturele beroepen & 44 & 24 & 24 \\
\hline Middelbare beroepen m.b.t. gedrag en maatschappij & 71 & 25 & 18 \\
\hline Middelbare verzorgende beroepen e.d. & 78 & 29 & 19 \\
\hline Hogere pedagogische beroepen & 61 & 9 & 40 \\
\hline Hogere landbouwkundige beroepen & 15 & 19 & 28 \\
\hline Hogere wiskundige, natuurwetenschappelijke beroepen & 55 & 26 & 11 \\
\hline Hogere technische beroepen & 10 & 14 & 37 \\
\hline Hogere transportberoepen & 8 & 34 & 23 \\
\hline Hogere (para)medische beroepen & 89 & 25 & 26 \\
\hline Hogere administratieve, commerciële, economische beroepen & 20 & 12 & 32 \\
\hline Hogere juridische, bestuurlijke, beveiligingsberoepen & 12 & 21 & 46 \\
\hline Hogere taalkundige, culturele beroepen & 49 & 12 & 33 \\
\hline Hogere beroepen mbt gedrag en maatschappij e.d. & 63 & 17 & 24 \\
\hline Hogere verzorgende beroepen & 63 & 16 & 42 \\
\hline Managers (HBO werk- en denkniveau) e.d. & 20 & 1 & 51 \\
\hline Wetenschappelijke pedagogische beroepen & 47 & 12 & 32 \\
\hline Wetenschappelijke landbouwkundige beroepen & 14 & 0 & 13 \\
\hline Wetenschappelijke wiskundige, natuurwetenschappelijke beroepen & 30 & 26 & 38 \\
\hline Wetenschappelijke technische beroepen & 10 & 13 & 35 \\
\hline Wetenschappelijke (para)medische beroepen e.d. & 50 & 8 & 37 \\
\hline Wetenschappelijke economische, administratieve beroepen e.d. & 19 & 10 & 37 \\
\hline Wetenschappelijke, juridische, bestuurlijke beroepen & 41 & 20 & 25 \\
\hline Wetenschappelijke beroepen m.b.t. gedrag en maatschappij e.d. & 60 & 19 & 32 \\
\hline Managers (wetenschappelijke werk- en denkniveau) & 11 & 1 & 78 \\
\hline Totaal & 47 & 25 & 25 \\
\hline
\end{tabular}

Bron: CBS/CWI/Etil/ROA 
Tabel 3.6

Discrepanties per bedrijfssector, Overijssel, april 2004

\begin{tabular}{lll}
\hline Bedrijfssector & Arbeidsmarktkrapte & Typering \\
\hline Landbouw en visserij & & \\
Voeding & 1.06 & hoog \\
Chemie & 0.99 & gemiddeld \\
Metaal en elektrotechniek & 0.16 & laag \\
Overige industrie & 0.35 & gemiddeld \\
Energie & 0.18 & laag \\
Bouw en onroerend goed & 0.07 & erg laag \\
Handel en reparatie & 0.59 & gemiddeld \\
Horeca en zakelijke dienstverlening & 0.50 & gemiddeld \\
Transport en communicatie & 0.45 & gemiddeld \\
Bank- en verzekeringswezen & 1.42 & hoog \\
Kwartaire diensten & 2.20 & erg hoog \\
Overheid en onderwijs & 0.77 & gemiddeld \\
& 0.66 & gemiddeld \\
Totaal & & \\
& & \\
\end{tabular}

Bron: CBS/CWI/Etil/ROA 
Tabel 3.7

Discrepanties per beroepssegment, Overijssel, april 2004

\begin{tabular}{|c|c|c|}
\hline Beroepssegment & Arbeidsmarktkrapte & Typering \\
\hline Elementaire beroepen & 0.41 & laag \\
\hline \multicolumn{3}{|l|}{ Lagere niet-specialistische beroepen } \\
\hline Lagere agrarische beroepen & 1.19 & hoog \\
\hline Lagere wiskundige, natuurwetenschappelijke beroepen & & \\
\hline Lagere technische beroepen & 1.10 & gemiddeld \\
\hline Lagere transportberoepen & 0.38 & laag \\
\hline \multicolumn{3}{|l|}{ Lagere (para)medische beroepen } \\
\hline Lagere administratieve, commerciële beroepen e.d. & 0.40 & laag \\
\hline Lagere beveiligingsberoepen & 9.20 & erg hoog \\
\hline Lagere verzorgende beroepen & 1.07 & gemiddeld \\
\hline Middelbare docenten transport-, sportvakken & 1.57 & hoog \\
\hline Middelbare agrarische beroepen & 0.64 & gemiddeld \\
\hline Middelbare wiskundige, natuurwetenschappelijke beroepen & 0.00 & erg laag \\
\hline Middelbare technische beroepen & 1.07 & gemiddeld \\
\hline Middelbare transportberoepen e.d. & 0.52 & laag \\
\hline Middelbare (para)medische beroepen & 1.61 & hoog \\
\hline Middelbare administratieve, commerciële beroepen e.d. & 0.85 & gemiddeld \\
\hline Middelbare juridische, bestuurlijke, beveiligingsberoepen & 0.27 & laag \\
\hline Middelbare taalkundige, culturele beroepen & 0.64 & gemiddeld \\
\hline Middelbare beroepen m.b.t. gedrag en maatschappij & 0.46 & laag \\
\hline Middelbare verzorgende beroepen e.d. & 1.31 & hoog \\
\hline Hogere pedagogische beroepen & 0.68 & gemiddeld \\
\hline Hogere landbouwkundige beroepen & 0.60 & laag \\
\hline Hogere wiskundige, natuurwetenschappelijke beroepen & 0.00 & erg laag \\
\hline Hogere technische beroepen & 1.63 & hoog \\
\hline \multicolumn{3}{|l|}{ Hogere transportberoepen } \\
\hline Hogere (para)medische beroepen & 2.20 & erg hoog \\
\hline \multicolumn{2}{|l|}{ Hogere juridische, bestuurlijke, beveiligingsberoepen } & gemiddeld \\
\hline Hogere taalkundige, culturele beroepen & 0.61 & laag \\
\hline Hogere beroepen mbt gedrag en maatschappij e.d. & 0.67 & gemiddeld \\
\hline Hogere verzorgende beroepen & 1.40 & hoog \\
\hline Managers (HBO werk- en denkniveau) e.d. & 1.53 & hoog \\
\hline \multicolumn{3}{|l|}{ Wetenschappelijke landbouwkundige beroepen } \\
\hline Wetenschappelijke technische beroepen & 1.03 & gemiddeld \\
\hline Wetenschappelijke (para)medische beroepen e.d. & 1.70 & erg hoog \\
\hline Wetenschappelijke economische, administratieve beroepen e.d. & 0.14 & erg laag \\
\hline Wetenschappelijke, juridische, bestuurlijke beroepen & 0.59 & laag \\
\hline Wetenschappelijke beroepen m.b.t. gedrag en maatschappij e.d. & 1.17 & gemiddeld \\
\hline \multicolumn{3}{|l|}{ Managers (wetenschappelijke werk- en denkniveau) } \\
\hline Totaal & 0.81 & gemiddeld \\
\hline
\end{tabular}

Bron: CBS/CWI/Etil/ROA 

4 De Overijsselse arbeidsmarkt tot 2008 

Tabel 4.1

Verwachte uitbreidingsvraag per bedrijfssector (als percentage van de werkgelegenheid), Overijssel, 2003-2008

\begin{tabular}{lll}
\hline Bedrijfssector & $\%$ & Typering
\end{tabular}

Landbouw en visserij

Voeding

$-10.6 \quad$ erg laag

Chemie

$-4.4 \quad$ laag

Metaal en elektrotechniek

-2.7 gemiddeld

Overige industrie

laag

Energie

$\begin{array}{ll}-9.5 & \text { laag } \\ -3.3 & \text { gemiddeld }\end{array}$

Bouw en onroerend goed

$\begin{array}{ll}-3.3 & \text { gemiddeld } \\ -0.5 & \end{array}$

Handel

Transport en communicatie

0.0 gemiddeld

Bank en verzekeringswezen

$\begin{aligned} 11.6 & \text { hoog } \\ 2.1 & \text { gemiddeld }\end{aligned}$

Horeca, reparatie en zak. diensten

$\begin{aligned}-9.7 & \text { laag } \\ 7.1 & \text { hoog }\end{aligned}$

Kwartaire diensten

Overheid en onderwijs

13.5 erg hoog

Totaal

Bron: ROA 
Tabel 4.2

Verwachte uitbreidingsvraag per beroepsgroep (als percentage van de werkgelegenheid), Overijssel, 20032008

Beroepsgroep

$\% \quad$ Typering

Leraar basisonderwijs

Docenten exacte, med. en verz. vakken $(2 e+3 e$ gr.)

Docenten exacte, med. en verz. vakken (1e gr.)

Docenten landbouw en techniek (2e en 3 e gr.)

Docenten landbouw en techniek (1e gr. en WO)

Docenten economisch-admin. vakken (2e en $3 \mathrm{e}$ gr.)

Docenten economisch-admin. vakken (1e gr.)

Docenten talen en expressie

Docenten letteren (1e gr. en WO)

Docenten sociale vakken (2e en $3 e$ gr.)

Docenten sociale vakken (1e gr.)

Docenten $2 e$ en $3 e$ graads zonder specialisatie

Docent 1 e graads zonder specialisatie

Onderwijskundig medewerkers

Onderwijskundigen en pedagogen

Rij-instructeurs

Zweminstructeurs

Sportinstructeurs

Tolken, vertalers en schrijvers

Bibliotheekassistenten

Bibliothecarissen

Grafisch ontwerpers

Kunstenaars

Geestelijk verzorgers

Geestelijken

Journalisten

Taalkundigen

Agrarische hulparbeiders

Agrarische arbeiders

Agrarische vakkrachten

Milieuhygiënisten en agrarisch vertegenwoordigers

Landbouwkundigen

Landbouwmachinebestuurders en vissers

Agrarische bedrijfshoofden

Productiemedewerkers

Laboratoriumassistenten

Laboranten

Technisch analisten

Natuurwetenschappers

Conciërges

Hoofden technische dienst

Werktuigbouwkundigen

Bouwvakkers

Aannemers en installateurs

Architecten en bouwkundig projectleiders

Weg- en waterbouwkundigen

Weg- en waterbouwkundige arbeiders

Weg- en waterbouwkundige vakkrachten

Weg- en waterbouwkundig ontwerpers en projectleiders

Metaalarbeiders

Bankwerkers en lassers

Bedrijfshoofden metaalbewerking

Assembleurs

Monteurs

Werktuigbouwk. ontwerpers en hoofden techn. dienst

10.8

asideld

hoog

- $\quad$ gemiddeld

- $\quad$ hoog

- laag

- $\quad$ gemiddeld

- $\quad$ hoog

8.3 gemiddeld

- $\quad$ laag

- $\quad$ gemiddeld

laag

gemiddeld

hoog

erg hoog

hoog

hoog

gemiddeld

erg hoog

gemiddeld

6.4 gemiddeld

Elektronicamonteurs

Monteurs en controleurs elektrotechn. producten

Elektromonteurs

Electrotechnisch ontwerpers en bedrijfshoofden

erg hoog

erg hoog

laag

laag

erg hoog

gemiddeld

gemiddeld

$-6.1 \quad$ laag

- $\quad$ erg laag

gemiddeld

gemiddeld

laag

laag

laag

erg hoog

erg hoog

hoog

hoog

hoog

erg laag

hoog

gemiddeld

gemiddeld

gemiddeld

erg hoog

gemiddeld

laag

gemiddeld

gemiddeld

2.7

laag

- laag

gemiddeld

$\begin{array}{ll}-9.3 & \text { erg laag } \\ -15.1 & \text { erg laag }\end{array}$

- $\quad$ gemiddeld

gemiddeld 
Tabel 4.2 (vervolg)

Verwachte uitbreidingsvraag per beroepsgroep (als percentage van de werkgelegenheid), Overijssel, 20032008

$\begin{array}{llll}\text { Beroepsgroep } & \% & \text { Typering }\end{array}$

Elektrotechnici

Grafisch productiepersoneel

Grafische vakkrachten

Mechanisch operators

Procesoperators

Procestechnologen

Materiaalkundigen

Confectie-arbeiders

Schoen- en kleermakers

Laders en lossers

Chauffeurs

Schippers en conducteurs

Vliegers, scheepskapiteins en leidinggevenden transport

Stewards

Verpleeghulpen en leerling-verpleegkundigen

Verplegenden en doktersassistenten

Therapeuten en verpleegkundigen

Artsen

Apothekersassistenten en medisch laboranten

Medisch analisten

Apothekers

Afdelingshoofden zorginstelling

Kantoorhulpen, inpakkers en colporteurs

Ondersteunende administratieve hulpkrachten

Bedrijfshoofden

Economen

Productieplanners

Organisatie-adviseurs

Organisatiedeskundigen

Receptionisten en administratieve employés

Boekhouders en secretaresses

Assistent accountants

Accountants

Verzekeringsagenten

Commercieel employés

Commercieel medewerkers

Technisch-commercieel employés

Technisch-bedrijfskundig medewerkers

Juridisch en fiscaal medewerkers

Juridisch, bestuurlijk medewerkers

Juristen

Administratieve transportemployés

Leidinggevenden

Managers

Medisch secretaresses

Programmeurs

Systeemanalisten

Informatici

Technisch systeemanalisten

Act.begeleiders en medew. arbeidsbemiddeling

Sociaal-cultureel werkers

Sociale raadslieden en hoofden personeelszaken

Sociaal-wetenschappelijk medewerkers

Sociaal-wetenschappelijk onderzoekers

Vakkenvullers

hoog

- $\quad$ gemiddeld

-14.8 erg laag

-1.9 laag

$-4.3 \quad$ laag

- $\quad$ erg laag

- $\quad$ gemiddeld

-1.7 laag

- laag

10.6 gemiddeld

-0.5 gemiddeld

- $\quad$ laag

- $\quad$ laag

- $\quad$ erg hoog

-1.9 laag

15.2 hoog

10.5 gemiddeld

7.9 gemiddeld

- hoog

- $\quad$ gemiddeld

- $\quad$ erg hoog

gemiddeld

- $\quad$ gemiddeld

3.3 gemiddeld

- erg laag

18.6 hoog

22.3 hoog

- erg hoog

$4.1 \quad$ gemiddeld

7.4 gemiddeld

0.3 gemiddeld

gemiddeld

-5.7 laag

2.4 gemiddeld

- $\quad$ erg laag

- laag

- $\quad$ hoog

- $\quad$ gemiddeld

$5.2 \quad$ gemiddeld

- $\quad$ gemiddeld

$0.5 \quad$ gemiddeld

$-0.9 \quad$ gemiddeld

- laag

19.9 hoog

27.7 erg hoog

- hoog

- $\quad$ erg laag

-12.9 erg laag

6 gemiddeld

- $\quad$ gemiddeld

- $\quad$ hoog

- hoog

Interieurverzorgers

12.3 hoog

4.9 gemiddeld

Verkopers

11.9 hoog

-10 erg laag 
Tabel 4.2 (vervolg)

Verwachte uitbreidingsvraag per beroepsgroep (als percentage van de werkgelegenheid), Overijssel, 20032008

Beroepsgroep

$\% \quad$ Typering

Hulpkrachten horeca en verzorging

Ziekenverzorgenden

Verzorgend personee

Café- en snackbarhouders

Bedrijfshoofden horeca

Bakkers en slagers

Asp. politie-agenten, soldaten en beveiligingshulpen

Agenten, onderofficieren en beveiligingsemployés

Politie-inspecteurs en officieren

Brandweerlieden

$\begin{aligned} 17.6 & \text { hoog } \\ 15.1 & \text { hoog } \\ 7.9 & \text { gemiddeld } \\ - & \text { laag } \\ 23 & \text { hoog } \\ - & \text { gemiddeld } \\ 9.6 & \text { gemiddeld } \\ 5.7 & \text { gemiddeld } \\ - & \text { laag } \\ - & \text { erg laag } \\ & \end{aligned}$

Totaal

Bron: ROA 
Tabel 4.3

Verwachte vervangingsvraag per beroepsgroep (als percentage van de werkgelegenheid), Overijssel, 20032008

Beroepsgroep

$\% \quad$ Typering

Leraar basisonderwijs

Docenten exacte, med. en verz. vakken $(2 e+3 e$ gr.)

Docenten exacte, med. en verz. vakken (1e gr.)

Docenten landbouw en techniek (2e en 3e gr.)

Docenten landbouw en techniek (1e gr. en WO)

Docenten economisch-admin. vakken (2e en $3 \mathrm{e}$ gr.)

Docenten economisch-admin. vakken (1e gr.)

Docenten talen en expressie

Docenten letteren (1e gr. en WO)

Docenten sociale vakken (2e en 3 e gr.)

Docenten sociale vakken (1e gr.)

Docenten 2e en $3 e$ graads zonder specialisatie

Docent 1 e graads zonder specialisatie

Onderwijskundig medewerkers

Onderwijskundigen en pedagogen

Rij-instructeurs

Zweminstructeurs

Sportinstructeurs

Tolken, vertalers en schrijvers

Bibliotheekassistenten

Bibliothecarissen

Grafisch ontwerpers

Kunstenaars

Geestelijk verzorgers

Geestelijken

Journalisten

Taalkundigen

Agrarische hulparbeiders

Agrarische arbeiders

Agrarische vakkrachten

Milieuhygiënisten en agrarisch vertegenwoordigers

Landbouwkundigen

Landbouwmachinebestuurders en vissers

Agrarische bedrijfshoofden

Productiemedewerkers

Laboratoriumassistenten

Laboranten

Technisch analisten

Natuurwetenschappers

Conciërges

Hoofden technische dienst

Werktuigbouwkundigen

Bouwvakkers

Aannemers en installateurs

17.5

hoog

erg hoog

- $\quad$ erg hoog

hoog

- $\quad$ erg hoog

- $\quad$ gemiddeld

$23.3 \quad$ hoog

- hoog

hoog

- hoog

- $\quad$ erg hoog

- $\quad$ laag

- hoog

laag

- $\quad$ erg hoog

- $\quad$ erg laag

- $\quad$ erg laag

- laag

14.2 laag

- $\quad$ erg laag

gemiddeld

erg hoog

erg hoog

- $\quad$ erg laag

- $\quad$ laag

- $\quad$ laag

$19.4 \quad$ gemiddeld

- $\quad$ gemiddeld

- $\quad$ gemiddeld

- hoog

- hoog

$17.7 \quad$ gemiddeld

14.6 laag

- hoog

- $\quad$ laag

- $\quad$ laag

gemiddeld

$29.9 \quad$ erg hoog

- $\quad$ gemiddeld

- $\quad$ hoog

Architecten en bouwkundig projectleiders

gemiddeld

gemiddeld

gemiddeld

Weg- en waterbouwkundigen

Weg- en waterbouwkundige arbeiders

Weg- en waterbouwkundige vakkrachten

Weg- en waterbouwkundig ontwerpers en projectleiders

Metaalarbeiders

Bankwerkers en lassers

Bedrijfshoofden metaalbewerking

Assembleurs

Monteurs

Werktuigbouwk. ontwerpers en hoofden techn. dienst

Elektronicamonteurs

Monteurs en controleurs elektrotechn. producten

Elektromonteurs
$20.2^{-}$

15.9

19.6

13.8

- $\quad$ gemiddeld

- $\quad$ hoog

16.1 gemiddeld

23.1 hoog

- $\quad$ gemiddeld

- $\quad$ gemiddeld

16.7 gemiddeld 
Tabel 4.3 (vervolg)

Verwachte vervangingsvraag per beroepsgroep (als percentage van de werkgelegenheid), Overijssel, 20032008

Beroepsgroep

$\% \quad$ Typering

Electrotechnisch ontwerpers en bedrijfshoofden

Elektrotechnici

Grafisch productiepersoneel

Grafische vakkrachten

hoog

Mechanisch operators

Procesoperators

Procestechnologen

Materiaalkundigen

Confectie-arbeiders

Schoen- en kleermakers

Laders en lossers

Chauffeurs

Schippers en conducteurs

Vliegers, scheepskapiteins en leidinggevenden transport

Stewards

Verpleeghulpen en leerling-verpleegkundigen

Verplegenden en doktersassistenten

Therapeuten en verpleegkundigen

Artsen

Apothekersassistenten en medisch laboranten

Medisch analisten

Apothekers

Afdelingshoofden zorginstelling

Kantoorhulpen, inpakkers en colporteurs

Ondersteunende administratieve hulpkrachten

Bedrijfshoofden

Economen

Productieplanners

Organisatie-adviseurs

Organisatiedeskundigen

Receptionisten en administratieve employés

Boekhouders en secretaresses

Assistent accountants

Accountants

Verzekeringsagenten

Commercieel employés

Commercieel medewerkers

Technisch-commercieel employés

Technisch-bedrijfskundig medewerkers

Juridisch en fiscaal medewerkers

Juridisch, bestuurlijk medewerkers

Juristen

Administratieve transportemployés

- laag

hoog

20 gemiddeld

20.4 gemiddeld

14.4 laag

- $\quad$ gemiddeld

- $\quad$ gemiddeld

23.8 hoog

- $\quad$ hoog

$9.3 \quad$ laag

13 laag

- $\quad$ hoog

- $\quad$ laag

- $\quad$ gemiddeld

16.4 gemiddeld

15.7 gemiddeld

21.2 hoog

16.6 gemiddeld

- $\quad$ gemiddeld

- $\quad$ gemiddeld

- $\quad$ gemiddeld

12.9 laag

- $\quad$ laag

13.4 laag

- $\quad$ erg laag

8.8 erg laag

12.7 laag

- hoog

7.9 erg laag

15.5 gemiddeld

- gemiddeld

- gemiddeld

12.3 laag

8.3 erg laag

- $\quad$ gemiddeld

- $\quad$ gemiddeld

- $\quad$ hoog

- $\quad$ hoog

13 laag

Leidinggevenden

28.3

Managers

Medisch secretaresses

Programmeurs

Systeemanalisten

Informatici

Technisch systeemanalisten

Act.begeleiders en medew. arbeidsbemiddeling

Sociaal-cultureel werkers

Sociale raadslieden en hoofden personeelszaken

Sociaal-wetenschappelijk medewerkers

Sociaal-wetenschappelijk onderzoekers

Vakkenvullers

gemiddeld

Interieurverzorgers

Verkopers

erg hoog

hoog

laag

$8.9 \quad$ laag

- $\quad$ erg laag

- laag

7.8 erg laag

16.6 gemiddeld

- $\quad$ gemiddeld

- $\quad$ gemiddeld

- $\quad$ gemiddeld

3.5 erg laag

15.1 gemiddeld

Winkeliers $\quad 14.8 \quad 1$ gemiddeld

64 
Tabel 4.3 (vervolg)

Verwachte vervangingsvraag per beroepsgroep (als percentage van de werkgelegenheid), Overijssel, 20032008

Beroepsgroep

$\% \quad$ Typering

Hulpkrachten horeca en verzorging

Ziekenverzorgenden

Verzorgend personee

Café- en snackbarhouders

Bedrijfshoofden horeca

Bakkers en slagers

Asp. politie-agenten, soldaten en beveiligingshulpen

Agenten, onderofficieren en beveiligingsemployés

Politie-inspecteurs en officieren

Brandweerlieden

$\begin{aligned} 19.8 & \text { gemiddeld } \\ 9.4 & \text { laag } \\ 15.9 & \text { gemiddeld } \\ - & \text { hoog } \\ 20.7 & \text { gemiddeld } \\ - & \text { gemiddeld } \\ 18.2 & \text { gemiddeld } \\ 30.6 & \text { erg hoog } \\ - & \text { erg hoog } \\ - & \text { erg laag }\end{aligned}$

Totaal

16.2

Bron: ROA 
Tabel 4.4

Verwachte baanopeningen per beroepsgroep (als percentage van de werkgelegenheid), Overijssel, 2003-2008

\begin{tabular}{|c|c|c|}
\hline Beroepsgroep & $\%$ & Typering \\
\hline Leraar basisonderwijs & 28.3 & gemiddeld \\
\hline Docenten exacte, med. en verz. vakken $(2 \mathrm{e}+3 \mathrm{e}$ gr. $)$ & - & hoog \\
\hline Docenten exacte, med. en verz. vakken (1e gr.) & - & hoog \\
\hline Docenten landbouw en techniek (2e en 3e gr.) & - & erg hoog \\
\hline Docenten landbouw en techniek (1e gr. en WO) & - & gemiddeld \\
\hline Docenten economisch-admin. vakken (2e en 3e gr.) & - & hoog \\
\hline Docenten economisch-admin. vakken (1e gr.) & - & hoog \\
\hline Docenten talen en expressie & 31.6 & hoog \\
\hline Docenten letteren (1e gr. en WO) & - & gemiddeld \\
\hline Docenten sociale vakken (2e en 3 e gr.) & - & gemiddeld \\
\hline Docenten sociale vakken (1e gr.) & - & gemiddeld \\
\hline Docenten $2 \mathrm{e}$ en $3 \mathrm{e}$ graads zonder specialisatie & - & hoog \\
\hline Docent 1 e graads zonder specialisatie & - & gemiddeld \\
\hline Onderwijskundig medewerkers & - & erg hoog \\
\hline Onderwijskundigen en pedagogen & - & gemiddeld \\
\hline Rij-instructeurs & - & hoog \\
\hline Zweminstructeurs & - & erg laag \\
\hline Sportinstructeurs & - & hoog \\
\hline Tolken, vertalers en schrijvers & - & gemiddeld \\
\hline Bibliotheekassistenten & 20.6 & gemiddeld \\
\hline Bibliothecarissen & - & \\
\hline Grafisch ontwerpers & - & hoog \\
\hline Kunstenaars & - & erg hoog \\
\hline Geestelijk verzorgers & - & erg hoog \\
\hline Geestelijken & - & hoog \\
\hline Journalisten & - & erg hoog \\
\hline Taalkundigen & - & gemiddeld \\
\hline Agrarische hulparbeiders & - & laag \\
\hline Agrarische arbeiders & 19.4 & laag \\
\hline Agrarische vakkrachten & - & laag \\
\hline Milieuhygiënisten en agrarisch vertegenwoordigers & - & gemiddeld \\
\hline Landbouwkundigen & - & gemiddeld \\
\hline Landbouwmachinebestuurders en vissers & - & gemiddeld \\
\hline Agrarische bedrijfshoofden & 17.7 & laag \\
\hline Productiemedewerkers & 14.6 & laag \\
\hline Laboratoriumassistenten & - & erg hoog \\
\hline Laboranten & - & erg hoog \\
\hline Technisch analisten & - & hoog \\
\hline Natuurwetenschappers & - & hoog \\
\hline Conciërges & 42.1 & hoog \\
\hline Hoofden technische dienst & - & gemiddeld \\
\hline Werktuigbouwkundigen & - & erg hoog \\
\hline Bouwvakkers & 25.6 & gemiddeld \\
\hline Aannemers en installateurs & 16.3 & laag \\
\hline Architecten en bouwkundig projectleiders & 20.8 & gemiddeld \\
\hline Weg- en waterbouwkundigen & - & erg hoog \\
\hline Weg- en waterbouwkundige arbeiders & 20.9 & gemiddeld \\
\hline Weg- en waterbouwkundige vakkrachten & 15.9 & laag \\
\hline Weg- en waterbouwkundig ontwerpers en projectleiders & - & laag \\
\hline Metaalarbeiders & 22.3 & gemiddeld \\
\hline Bankwerkers en lassers & 13.8 & erg laag \\
\hline Bedrijfshoofden metaalbewerking & - & laag \\
\hline Assembleurs & - & gemiddeld \\
\hline Monteurs & 16.1 & laag \\
\hline Werktuigbouwk. ontwerpers en hoofden techn. dienst & 23.1 & gemiddeld \\
\hline Elektronicamonteurs & - & laag \\
\hline Monteurs en controleurs elektrotechn. producten & - & gemiddeld \\
\hline Elektromonteurs & 16.7 & laag \\
\hline Electrotechnisch ontwerpers en bedrijfshoofden & - & gemiddeld \\
\hline Elektrotechnici & - & hoog \\
\hline
\end{tabular}


Tabel 4.4 (vervolg)

Verwachte baanopeningen per beroepsgroep (als percentage van de werkgelegenheid), Overijssel, 2003-2008

Beroepsgroep

$\% \quad$ Typering

Grafisch productiepersonee

Grafische vakkrachten
Mechanisch operators

Procesoperators

Procestechnologen

Materiaalkundigen

Confectie-arbeiders

Schoen- en kleermakers

Laders en lossers

Chauffeurs

Schippers en conducteurs

Vliegers, scheepskapiteins en leidinggevenden transport

Stewards

Verpleeghulpen en leerling-verpleegkundigen

Verplegenden en doktersassistenten

Therapeuten en verpleegkundigen

Artsen

Apothekersassistenten en medisch laboranten

Medisch analisten

Apothekers

Afdelingshoofden zorginstelling

Kantoorhulpen, inpakkers en colporteurs

Ondersteunende administratieve hulpkrachten

Bedrijfshoofden

Economen

Productieplanners

Organisatie-adviseurs

Organisatiedeskundigen

Receptionisten en administratieve employés

Boekhouders en secretaresses

Assistent accountants

Accountants

Verzekeringsagenten

Commercieel employés

Commercieel medewerkers

Technisch-commercieel employés

Technisch-bedrijfskundig medewerkers

Juridisch en fiscaal medewerkers

Juridisch, bestuurlijk medewerkers

Juristen

Administratieve transportemployés

Leidinggevenden

Managers

Medisch secretaresses

Programmeurs

Systeemanalisten

Informatici

Technisch systeemanalisten

Act.begeleiders en medew. arbeidsbemiddeling

Sociaal-cultureel werkers

Sociale raadslieden en hoofden personeelszaken

Sociaal-wetenschappelijk medewerkers

Sociaal-wetenschappelijk onderzoekers

Vakkenvullers

Interieurverzorgers

Verkopers

Winkeliers

Hulpkrachten horeca en verzorging

Ziekenverzorgenden

Verzorgend personeel
20

gemiddeld

gemiddeld

gemiddeld

erg laag

$\begin{aligned} 14.4 & \text { erg laad } \\ - & \text { laag }\end{aligned}$

gemiddeld

23.8 gemiddeld

gemiddeld

laag

13 erg laag

gemiddeld

erg laag

erg hoog

laag

hoog

hoog

gemiddeld

hoog

gemiddeld

erg hoog

15.7 laag

- $\quad$ erg laag

16.7 laag

- $\quad$ erg laag

gemiddeld

hoog

erg hoog

gemiddeld

laag

laag

gemiddeld

gemiddeld

12.3

10.7

erg laag

erg laag

laag

laag

hoog

gemiddeld

laag

laag

gemiddeld

gemiddeld

erg laag

gemiddeld

hoog

gemiddeld

erg laag

erg laag

gemiddeld

gemiddeld

hoog

hoog

laag

gemiddeld

gemiddeld

laag

hoog

gemiddeld

gemiddeld 
Tabel 4.4 (vervolg)

Verwachte baanopeningen per beroepsgroep (als percentage van de werkgelegenheid), Overijssel, 2003-2008

Beroepsgroep

$\% \quad$ Typering

Café- en snackbarhouders

Bedrijfshoofden horeca

Bakkers en slagers

Asp. politie-agenten, soldaten en beveiligingshulpen

Agenten, onderofficieren en beveiligingsemployés

Politie-inspecteurs en officieren

Brandweerlieden

gemiddeld

$43.7 \quad$ hoog

- $\quad$ gemiddeld

$27.8 \quad$ gemiddeld

36.3 hoog

gemiddeld

- $\quad$ erg laag

Totaal

22.5

Bron: ROA 
Tabel 4.5

Indicator Toekomstige knelpunten in de personeelsvoorziening per Beroep (ITKB) per beroepsgroep, Overijssel, 2003-2008 (alleen elementaire, lagere en middelbare beroepen)

Beroepsgroep

ITKB Typering

Rij-instructeurs

Zweminstructeurs

Sportinstructeurs

Bibliotheekassistenten

Grafisch ontwerpers

Agrarische hulparbeiders

Agrarische arbeiders

Agrarische vakkrachten

Landbouwmachinebestuurders en vissers

Agrarische bedrijfshoofden

Productiemedewerkers

Laboratoriumassistenten

Laboranten

Conciërges

Hoofden technische dienst

Bouwvakkers

Aannemers en installateurs

Weg- en waterbouwkundige arbeiders

Weg- en waterbouwkundige vakkrachten

Metaalarbeiders

Bankwerkers en lassers

Assembleurs

Monteurs

Elektronicamonteurs

Monteurs en controleurs elektrotechn. producten

Elektromonteurs

Grafisch productiepersoneel

Grafische vakkrachten

Mechanisch operators

Procesoperators

Confectie-arbeiders

Schoen- en kleermakers

Laders en lossers

Chauffeurs

Schippers en conducteurs

Stewards

Verpleeghulpen en leerling-verpleegkundigen

Verplegenden en doktersassistenten

Apothekersassistenten en medisch laboranten

Kantoorhulpen, inpakkers en colporteurs

Ondersteunende administratieve hulpkrachten

Productieplanners

Receptionisten en administratieve employés

Boekhouders en secretaresses

Verzekeringsagenten

Commercieel employés

Technisch-commercieel employés

Juridisch en fiscaal medewerkers

Administratieve transportemployés

Medisch secretaresses

Programmeurs

Act.begeleiders en medew. arbeidsbemiddeling

Vakkenvullers

Interieurverzorgers

geen

- vrijwel geen

- $\quad$ vrijwel geen

- vrijwel geen

- vrijwel geen

- geen

0.98 geen

- vrijwel geen

- geen

0.97 vrijwel geen

0.92 enige

- vrijwel geen

- groot

- geen

- zeer groot

0.95 vrijwel geen

0.84 zeer groot

- vrijwel geen

0.91 groot

0.95 vrijwel geen

0.84 zeer groot

- vrijwel geen

0.91 groot

- zeer groot

- groot

0.92 enige

groot

0.94 vrijwel geen

0.95 vrijwel geen

0.93 vrijwel geen

0.98 geen

- geen

0.96 vrijwel geen

0.96 vrijwel geen

- vrijwel geen

- zeer groot

- geen

0.94 vrijwel geen

0.86 zeer groot

0.94 vrijwel geen

- geen

0.92 groot

0.96 vrijwel geen

0.96 vrijwel geen

- vrijwel geen

0.93 enige

- vrijwel geen

- $\quad$ vrijwel geen

- vrijwel geen

- vrijwel geen

0.94 vrijwel geen

0.95 vrijwel geen

- geen

0.98 geen 
Tabel 4.5 (vervolg)

Indicator Toekomstige Knelpunten in de personeelsvoorziening per Beroep (ITKB) per beroepsgroep, Overijssel, 2003-2008 (alleen elementaire, lagere en middelbare beroepen)

\begin{tabular}{lrc}
\hline Beroepsgroep & ITKB & Typering \\
\hline Verkopers & & \\
Winkeliers & 0.97 & vrijwel geen \\
Hulpkrachten horeca en verzorging & 0.97 & vrijwel geen \\
Ziekenverzorgenden & $0.96 \quad$ vrijwel geen \\
Verzorgend personeel & 0.97 & vrijwel geen \\
Café- en snackbarhouders & 0.95 & vrijwel geen \\
Bedrijfshoofden horeca & - & vrijwel geen \\
Bakkers en slagers & - & zeer groot \\
Asp. politie-agenten, soldaten en beveiligingshulpen & - & vrijwel geen \\
Agenten, onderofficieren en beveiligingsemployés & $0.92 \quad$ groot \\
Brandweerlieden & 0.89 groot \\
& - & enige
\end{tabular}

Bron: ROA 
Tabel 4.6

Verwachte uitbreidingsvraag per opleidingstype (als percentage van de werkgelegenheid), Overijssel, 20032008

$\begin{array}{lll}\text { Opleidingstype } & \% \quad \text { Typering }\end{array}$

Basisonderwijs

erg laag

VMBO theorie

5.2 gemiddeld

VMBO landbouw en natuurlijke omgeving

29.7

$-0.5$

VMBO installatietechniek

VMBO mechanische techniek

VMBO fijnmechanische techniek

VMBO voertuigentechniek

VMBO elektrotechniek

VMBO grafische techniek

VMBO brood en banket

VMBO transport en logistiek

VMBO administratie, handel en mode

VMBO consumptief en levensmiddelentechniek

VMBO (uiterlijke) verzorging

VMBO beveiliging

\section{HAVO/VWO}

MBO voeding, natuur en milieu

MBO groene ruimte

MBO laboratorium

MBO bouw

MBO grond-, weg- en waterbouw

MBO installatietechniek

MBO werktuigbouw en mechanische techniek

MBO fijnmechanische techniek

MBO motorvoertuigentechniek en tweewielers

MBO vliegtuigtechniek

MBO operationele techniek

MBO elektrotechniek

MBO grafische techniek

MBO procestechniek

MBO brood en banket

MBO levensmiddelentechniek/vleesverwerking

MBO vervoer

MBO dokters-, tandarts- en dierenartsassistent

MBO apothekersassistent

MBO verpleging

MBO gezondheidstechniek

MBO sociaal-pedagogisch en welzijn

$\mathrm{MBO}$ verzorging

MBO uiterlijke verzorging

MBO horeca

MBO beweging en therapie

MBO administratie en logistiek

MBO handel

MBO secretariaat

MBO toerisme en recreatie

MBO facilitaire dienstverlening

MBO ICT

MBO geld, bank en belastingen

MBO verzekeringswezen

MBO openbare orde en veiligheid

$-16$.

$-16.4 \quad$ laag

- erg laag

-31.3 erg laag

-6.9 laag

- $\quad$ erg laag

1.7 erg laag

-1.7 laag

12.1 gemiddeld

-25.1 erg laag

2.6 gemiddeld

- hoog

$15.2 \operatorname{hoog}$

$5.4 \quad$ gemiddeld

8.8 gemiddeld

- hoog

8.9 gemiddeld

-2 laag

-1.2 gemiddeld

-7.8 laag

- erg laag

1.3 gemiddeld

-3 laag

-17.9 laag

- gemiddeld

- laag

9 gemiddeld

14.8 hoog

- gemiddeld

- hoog

12.9 hoog

- hoog

10.2 gemiddeld

-1.9 laag

14.6 hoog

25.7 erg hoog

- gemiddeld

3.2 gemiddeld

-2.8 laag

7.1 gemiddeld

- gemiddeld

-3.1 laag

3.6 gemiddeld

- laag

- $\quad$ erg laag

1.3 gemiddeld

HBO lerarenopleiding basisonderwijs

HBO lerarenopleiding talen

12 gemiddeld

- laag 
Tabel 4.6 (vervolg)

Verwachte uitbreidingsvraag per opleidingstype (als percentage van de werkgelegenheid), Overijssel, 20032008

Opleidingstype

HBO lerarenopleiding natuur en techniek HBO lerarenopleiding economie en maatschappij HBO lerarenopleiding lichamelijke opvoeding HBO lerarenopleiding medisch en verzorging HBO lerarenopleiding expressie $\mathrm{HBO}$ tolk en vertaler

$\mathrm{HBO}$ landbouw en veeteelt

HBO milieukunde en levensmiddelentechnologie

HBO laboratorium

HBO bouwkunde

HBO civiele techniek

$\mathrm{HBO}$ werktuigbouwkunde

HBO elektrotechniek

HBO informatica

HBO chemische technologie

$\mathrm{HBO}$ vervoer en logistiek

$\mathrm{HBO}$ verpleegkunde

HBO (fysio)therapie

$\mathrm{HBO}$ voeding

$\mathrm{HBO}$ radiologie

HBO accountancy en bedrijfseconomie

HBO commerciële economie

HBO toerisme en recreatie

$\mathrm{HBO}$ recht en bestuur

$\mathrm{HBO}$ secretariaat

HBO bedrijfskunde

HBO communicatie en journalistiek

HBO maatschappelijk werk en hulpverlening

HBO personeelswerk

HBO bibliotheek en documentatie

HBO uitvoerende en beeldende kunsten

$\mathrm{HBO}$ openbare orde en veiligheid

$\% \quad$ Typering

WO letteren

WO theologie

WO landbouw en milieukunde

WO wiskunde en natuurwetenschappen

WO bouwkunde

WO civiele techniek

WO werktuigbouwkunde

WO elektrotechniek

WO informatica en bestuurlijke informatiekunde

WO (dier)geneeskunde

WO tandheelkunde

WO farmacie en medische biologie

WO econom(etr)ie

WO bedrijfskunde

WO accountancy en belastingen

WO rechten en bestuurskunde

WO sociale wetenschappen

WO kunstwetenschappen

\begin{tabular}{|c|c|}
\hline $\begin{array}{r}5.5 \\
13.1\end{array}$ & $\begin{array}{l}\text { gemiddeld } \\
\text { hoog }\end{array}$ \\
\hline- & gemiddeld \\
\hline- & hoog \\
\hline - & gemiddeld \\
\hline - & erg hoog \\
\hline- & hoog \\
\hline - & gemiddeld \\
\hline-0.4 & gemiddeld \\
\hline-2.5 & laag \\
\hline- & laag \\
\hline-12 & laag \\
\hline-0.5 & gemiddeld \\
\hline 17 & hoog \\
\hline - & gemiddeld \\
\hline - & erg laag \\
\hline 22.7 & hoog \\
\hline 23.3 & hoog \\
\hline - & - \\
\hline - & hoog \\
\hline-2.1 & laag \\
\hline 5.2 & gemiddeld \\
\hline - & hoog \\
\hline - & hoog \\
\hline - & gemiddeld \\
\hline 4.4 & gemiddeld \\
\hline - & erg hoog \\
\hline 3.5 & gemiddeld \\
\hline - & laag \\
\hline - & erg hoog \\
\hline 15.9 & hoog \\
\hline 5.5 & gemiddeld \\
\hline - & hoog \\
\hline- & laag \\
\hline - & gemiddeld \\
\hline 3.4 & gemiddeld \\
\hline - & erg hoog \\
\hline - & gemiddeld \\
\hline- & gemiddeld \\
\hline - & gemiddeld \\
\hline - & erg hoog \\
\hline 9.4 & gemiddeld \\
\hline - & erg hoog \\
\hline - & hoog \\
\hline - & erg hoog \\
\hline 10.9 & gemiddeld \\
\hline - & hoog \\
\hline 6 & gemiddeld \\
\hline 23.4 & erg hoog \\
\hline - & erg hoog \\
\hline 4.1 & - \\
\hline
\end{tabular}

Totaal

Bron: ROA 
Tabel 4.7

Verwachte vervangingsvraag per opleidingstype (als percentage van de werkgelegenheid), Overijssel, 20032008

$\begin{array}{lll}\text { Opleidingstype } & \% & \text { Typering }\end{array}$

Basisonderwijs

VMBO theorie

VMBO landbouw en natuurlijke omgeving

VMBO bouwtechniek

VMBO installatietechniek

VMBO mechanische techniek

VMBO fijnmechanische techniek

VMBO voertuigentechniek

VMBO elektrotechniek

VMBO grafische techniek

VMBO brood en banket

VMBO transport en logistiek

VMBO administratie, handel en mode

VMBO consumptief en levensmiddelentechniek

VMBO (uiterlijke) verzorging

VMBO beveiliging

\section{HAVO/VWO}

MBO voeding, natuur en milieu

MBO groene ruimte

MBO laboratorium

MBO bouw

MBO grond-, weg- en waterbouw

MBO installatietechniek

MBO werktuigbouw en mechanische techniek

MBO fijnmechanische techniek

MBO motorvoertuigentechniek en tweewielers

MBO vliegtuigtechniek

MBO operationele techniek

MBO elektrotechniek

MBO grafische techniek

MBO procestechniek

MBO brood en banket

MBO levensmiddelentechniek/vleesverwerking

MBO vervoer

MBO dokters-, tandarts- en dierenartsassistent

MBO apothekersassistent

$\mathrm{MBO}$ verpleging

MBO gezondheidstechniek

MBO sociaal-pedagogisch en welzijn

$M B O$ verzorging

MBO uiterlijke verzorging

MBO horeca

MBO beweging en therapie

MBO administratie en logistiek

MBO handel

MBO secretariaat

MBO toerisme en recreatie

MBO facilitaire dienstverlening

MBO ICT

MBO geld, bank en belastingen

MBO verzekeringswezen

MBO openbare orde en veiligheid

HBO lerarenopleiding basisonderwijs

HBO lerarenopleiding talen
26.5

hoog

25.6 hoog

19 gemiddeld

27.7 hoog

- $\quad$ hoog

29.9 erg hoog

- hoog

40.5 erg hoog

30.6 erg hoog

erg hoog

erg hoog

15.7 gemiddeld

25.2 hoog

29.6 erg hoog

21.8 hoog

- gemiddeld

16.6 gemiddeld

17.4 gemiddeld

19.8 gemiddeld

- $\quad$ gemiddeld

18.9 gemiddeld

17.1 gemiddeld

21.6 hoog

22.5 hoog

- laag

19.6 gemiddeld

erg hoog

hoog

20.2 gemiddeld

20.6 gemiddeld

erg laag

gemiddeld

$17.6 \quad$ gemiddeld

18.4 gemiddeld

- $\quad$ laag

gemiddeld

$20.1 \quad$ gemiddeld

- laag

13.5 laag

16 gemiddeld

17.7 gemiddeld

23.5 hoog

- $\quad$ gemiddeld

18.9 gemiddeld

21.2 hoog

13.2 laag

- hoog

20.9 gemiddeld

18.7 gemiddeld

- gemiddeld

hoog

27.4 hoog

18.3 gemiddeld

- hoog 
Tabel 4.7 (vervolg)

Verwachte vervangingsvraag per opleidingstype (als percentage van de werkgelegenheid), Overijssel, 20032008

Opleidingstype

$\% \quad$ Typering

HBO lerarenopleiding natuur en techniek

HBO lerarenopleiding economie en maatschappij

HBO lerarenopleiding lichamelijke opvoeding

$\mathrm{HBO}$ lerarenopleiding medisch en verzorging

HBO lerarenopleiding expressie

$\mathrm{HBO}$ tolk en vertaler

HBO landbouw en veeteelt

HBO milieukunde en levensmiddelentechnologie

HBO laboratorium

HBO bouwkunde

HBO civiele techniek

$\mathrm{HBO}$ werktuigbouwkunde

$\begin{array}{ll}3.8 & \text { laag } \\ 28.5 & \text { erg }\end{array}$

28.5 erg hoog

- $\quad$ laag

- $\quad$ laag

- $\quad$ erg hoog

- $\quad$ gemiddeld

- $\quad$ erg laag

- laag

HBO elektrotechniek

$24.7 \quad$ hoog

18.4 gemiddeld

HBO informatica

HBO chemische technologie

$\mathrm{HBO}$ vervoer en logistiek

$\mathrm{HBO}$ verpleegkunde

HBO (fysio)therapie

$\mathrm{HBO}$ voeding

$\mathrm{HBO}$ radiologie

HBO accountancy en bedrijfseconomie

HBO commerciële economie

$\mathrm{HBO}$ toerisme en recreatie

$\mathrm{HBO}$ recht en bestuur

$\mathrm{HBO}$ secretariaat

HBO bedrijfskunde

HBO communicatie en journalistiek

HBO maatschappelijk werk en hulpverlening

HBO personeelswerk

HBO bibliotheek en documentatie

HBO uitvoerende en beeldende kunsten

$\mathrm{HBO}$ openbare orde en veiligheid

18.5

18.7

hoog

gemiddeld

1.3 laag

gemiddeld

laag

8.8 erg laag

19.4 gemiddeld

- $\quad$ -

- $\quad$ gemiddeld

16.6 gemiddeld

$9 \quad$ laag

- $\quad$ erg laag

- gemiddeld

- $\quad$ hoog

$11.5 \quad$ laag

- $\quad$ laag

18.4 gemiddeld

- $\quad$ hoog

- laag

WO letteren

WO theologie

WO landbouw en milieukunde

WO wiskunde en natuurwetenschappen

WO bouwkunde

WO civiele techniek

WO werktuigbouwkunde

WO elektrotechniek

WO informatica en bestuurlijke informatiekunde

WO (dier)geneeskunde

WO tandheelkunde

WO farmacie en medische biologie

WO econom(etr)ie

WO bedrijfskunde

WO accountancy en belastingen

WO rechten en bestuurskunde

$17.7 \quad$ gemiddeld

- $\quad$ erg hoog

WO sociale wetenschappen

gemiddeld

WO kunstwetenschappen

laag

- $\quad$ laag

19.2 gemiddeld

- $\quad$ laag

- $\quad$ erg laag

- $\quad$ erg laag

- $\quad$ laag

$24.1 \quad$ erg laag

- $\quad$ laag

- $\quad$ erg laag

- laag

3.8 erg laag

- gemiddeld

18.7 gemiddeld

20.9 gemiddeld

- $\quad$ erg laag

Totaal

20.3

Bron: ROA 
Tabel 4.8

Verwachte baanopeningen per opleidingstype (als percentage van de werkgelegenheid), Overijssel, 2003-2008

\begin{tabular}{|c|c|c|}
\hline Opleidingstype & $\%$ & Typering \\
\hline Basisonderwijs & 26.5 & gemiddeld \\
\hline VMBO theorie & 30.9 & gemiddeld \\
\hline VMBO landbouw en natuurlijke omgeving & 19.0 & laag \\
\hline VMBO bouwtechniek & 27.7 & gemiddeld \\
\hline VMBO installatietechniek & - & gemiddeld \\
\hline VMBO mechanische techniek & 29.9 & gemiddeld \\
\hline VMBO fijnmechanische techniek & - & gemiddeld \\
\hline VMBO voertuigentechniek & 40.5 & hoog \\
\hline VMBO elektrotechniek & 30.6 & gemiddeld \\
\hline VMBO grafische techniek & - & hoog \\
\hline VMBO brood en banket & - & gemiddeld \\
\hline VMBO transport en logistiek & 15.7 & erg laag \\
\hline VMBO administratie, handel en mode & 37.3 & hoog \\
\hline VMBO consumptief en levensmiddelentechniek & 29.6 & gemiddeld \\
\hline VMBO (uiterlijke) verzorging & 24.4 & gemiddeld \\
\hline VMBO beveiliging & & hoog \\
\hline HAVO/VWO & 31.8 & hoog \\
\hline MBO voeding, natuur en milieu & 22.8 & gemiddeld \\
\hline MBO groene ruimte & 28.6 & gemiddeld \\
\hline MBO laboratorium & - & hoog \\
\hline MBO bouw & 27.8 & gemiddeld \\
\hline MBO grond-, weg- en waterbouw & 17.1 & laag \\
\hline MBO installatietechniek & 21.6 & gemiddeld \\
\hline MBO werktuigbouw en mechanische techniek & 22.5 & gemiddeld \\
\hline MBO fijnmechanische techniek & - & erg laag \\
\hline MBO motorvoertuigentechniek en tweewielers & 21.0 & laag \\
\hline MBO vliegtuigtechniek & - & hoog \\
\hline MBO operationele techniek & - & gemiddeld \\
\hline MBO elektrotechniek & 20.2 & laag \\
\hline MBO grafische techniek & 20.6 & laag \\
\hline MBO procestechniek & - & laag \\
\hline MBO brood en banket & - & laag \\
\hline MBO levensmiddelentechniek/vleesverwerking & 26.6 & gemiddeld \\
\hline MBO vervoer & 33.2 & hoog \\
\hline MBO dokters-, tandarts- en dierenartsassistent & - & gemiddeld \\
\hline MBO apothekersassistent & - & hoog \\
\hline MBO verpleging & 33.0 & hoog \\
\hline MBO gezondheidstechniek & - & hoog \\
\hline MBO sociaal-pedagogisch en welzijn & 23.8 & gemiddeld \\
\hline MBO verzorging & 16.0 & laag \\
\hline MBO uiterlijke verzorging & 32.4 & hoog \\
\hline MBO horeca & 49.2 & erg hoog \\
\hline MBO beweging en therapie & - & gemiddeld \\
\hline MBO administratie en logistiek & 22.2 & gemiddeld \\
\hline MBO handel & 21.2 & laag \\
\hline MBO secretariaat & 20.3 & laag \\
\hline MBO toerisme en recreatie & - & gemiddeld \\
\hline MBO facilitaire dienstverlening & 20.9 & laag \\
\hline MBO ICT & 22.3 & gemiddeld \\
\hline MBO geld, bank en belastingen & - & laag \\
\hline MBO verzekeringswezen & - & gemiddeld \\
\hline MBO openbare orde en veiligheid & 28.7 & gemiddeld \\
\hline HBO lerarenopleiding basisonderwijs & 30.3 & gemiddeld \\
\hline HBO lerarenopleiding talen & - & gemiddeld \\
\hline HBO lerarenopleiding natuur en techniek & 19.3 & laag \\
\hline
\end{tabular}


Tabel 4.8 (vervolg)

Verwachte baanopeningen per opleidingstype (als percentage van de werkgelegenheid), Overijssel, 2003-2008

\begin{tabular}{|c|c|c|}
\hline Opleidingstype & $\%$ & Typering \\
\hline HBO lerarenopleiding economie en maatschappij & 41.6 & erg hoog \\
\hline HBO lerarenopleiding lichamelijke opvoeding & - & laag \\
\hline HBO lerarenopleiding medisch en verzorging & - & hoog \\
\hline HBO lerarenopleiding expressie & - & gemiddeld \\
\hline HBO tolk en vertaler & - & erg hoog \\
\hline HBO landbouw en veeteelt & - & gemiddeld \\
\hline HBO milieukunde en levensmiddelentechnologie & - & erg laag \\
\hline HBO laboratorium & 24.7 & gemiddeld \\
\hline HBO bouwkunde & 18.4 & laag \\
\hline HBO civiele techniek & - & gemiddeld \\
\hline HBO werktuigbouwkunde & 18.5 & laag \\
\hline HBO elektrotechniek & 18.7 & laag \\
\hline HBO informatica & 28.3 & gemiddeld \\
\hline HBO chemische technologie & - & laag \\
\hline HBO vervoer en logistiek & - & erg laag \\
\hline HBO verpleegkunde & 31.6 & hoog \\
\hline HBO (fysio)therapie & 42.7 & erg hoog \\
\hline $\mathrm{HBO}$ voeding & - & - \\
\hline HBO radiologie & - & gemiddeld \\
\hline HBO accountancy en bedrijfseconomie & 16.6 & laag \\
\hline HBO commerciële economie & 14.2 & erg laag \\
\hline HBO toerisme en recreatie & - & gemiddeld \\
\hline HBO recht en bestuur & - & hoog \\
\hline HBO secretariaat & - & gemiddeld \\
\hline HBO bedrijfskunde & 15.9 & erg laag \\
\hline HBO communicatie en journalistiek & - & erg hoog \\
\hline HBO maatschappelijk werk en hulpverlening & 21.9 & gemiddeld \\
\hline HBO personeelswerk & - & gemiddeld \\
\hline HBO bibliotheek en documentatie & - & erg hoog \\
\hline HBO uitvoerende en beeldende kunsten & 33.6 & hoog \\
\hline HBO openbare orde en veiligheid & - & hoog \\
\hline WO letteren & - & hoog \\
\hline WO theologie & - & erg laag \\
\hline WO landbouw en milieukunde & - & laag \\
\hline WO wiskunde en natuurwetenschappen & 22.6 & gemiddeld \\
\hline WO bouwkunde & - & hoog \\
\hline WO civiele techniek & - & laag \\
\hline WO werktuigbouwkunde & - & erg laag \\
\hline WO elektrotechniek & - & erg laag \\
\hline WO informatica en bestuurlijke informatiekunde & - & hoog \\
\hline WO (dier)geneeskunde & 33.4 & hoog \\
\hline WO tandheelkunde & - & erg hoog \\
\hline WO farmacie en medische biologie & - & gemiddeld \\
\hline WO econom(etr)ie & - & erg hoog \\
\hline WO bedrijfskunde & 14.7 & erg laag \\
\hline WO accountancy en belastingen & - & gemiddeld \\
\hline WO rechten en bestuurskunde & 24.8 & gemiddeld \\
\hline WO sociale wetenschappen & 44.3 & erg hoog \\
\hline WO kunstwetenschappen & - & erg hoog \\
\hline Totaal & 29.1 & - \\
\hline
\end{tabular}

Bron: ROA 
Tabel 4.9

Verwachte arbeidsmarktinstroom van schoolverlaters per opleidingstype (als percentage van de werkgelegenheid), Overijssel, 2003-2008 (alleen lagere en middelbare opleidingen)

\begin{tabular}{|c|c|c|}
\hline Opleidingstype & $\%$ & Typering \\
\hline Basisonderwijs & 23.8 & gemiddeld \\
\hline VMBO theorie & 23.1 & gemiddeld \\
\hline VMBO landbouw en natuurlijke omgeving & 31.1 & hoog \\
\hline VMBO bouwtechniek & 26.0 & gemiddeld \\
\hline VMBO installatietechniek & - & hoog \\
\hline VMBO mechanische techniek & 23.2 & gemiddeld \\
\hline VMBO fijnmechanische techniek & - & hoog \\
\hline VMBO voertuigentechniek & 27.3 & gemiddeld \\
\hline VMBO elektrotechniek & - & erg laag \\
\hline VMBO grafische techniek & - & hoog \\
\hline VMBO brood en banket & - & laag \\
\hline VMBO transport en logistiek & 41.7 & erg hoog \\
\hline VMBO administratie, handel en mode & 50.1 & erg hoog \\
\hline VMBO consumptief en levensmiddelentechniek & 31.5 & hoog \\
\hline VMBO (uiterlijke) verzorging & - & erg hoog \\
\hline HAVO/VWO & 36.8 & hoog \\
\hline MBO voeding, natuur en milieu & 19.1 & gemiddeld \\
\hline MBO groene ruimte & 28.7 & hoog \\
\hline MBO laboratorium & - & laag \\
\hline MBO bouw & 16.5 & gemiddeld \\
\hline MBO grond-, weg- en waterbouw & 16.1 & gemiddeld \\
\hline MBO installatietechniek & - & hoog \\
\hline MBO werktuigbouw en mechanische techniek & 9.4 & laag \\
\hline MBO fijnmechanische techniek & - & gemiddeld \\
\hline MBO motorvoertuigentechniek en tweewielers & 32.4 & hoog \\
\hline MBO vliegtuigtechniek & - & laag \\
\hline MBO operationele techniek & - & erg hoog \\
\hline MBO elektrotechniek & 15.6 & gemiddeld \\
\hline MBO grafische techniek & - & gemiddeld \\
\hline MBO procestechniek & - & erg laag \\
\hline MBO brood en banket & - & gemiddeld \\
\hline MBO levensmiddelentechniek/vleesverwerking & - & laag \\
\hline MBO vervoer & 35.4 & hoog \\
\hline MBO dokters-, tandarts- en dierenartsassistent & - & gemiddeld \\
\hline MBO apothekersassistent & - & gemiddeld \\
\hline MBO verpleging & 21.0 & gemiddeld \\
\hline MBO gezondheidstechniek & - & erg laag \\
\hline MBO sociaal-pedagogisch en welzijn & 52.7 & erg hoog \\
\hline MBO verzorging & 27.3 & gemiddeld \\
\hline MBO uiterlijke verzorging & 18.6 & gemiddeld \\
\hline MBO horeca & 38.0 & hoog \\
\hline MBO beweging en therapie & - & laag \\
\hline MBO administratie en logistiek & 13.7 & laag \\
\hline MBO handel & 27.3 & gemiddeld \\
\hline MBO secretariaat & 17.2 & gemiddeld \\
\hline MBO toerisme en recreatie & - & hoog \\
\hline MBO facilitaire dienstverlening & 39.4 & hoog \\
\hline MBO ICT & 42.3 & erg hoog \\
\hline MBO geld, bank en belastingen & - & laag \\
\hline MBO verzekeringswezen & - & erg hoog \\
\hline MBO openbare orde en veiligheid & 13.1 & laag \\
\hline Totaal (inclusief hogere en wetenschappelijke opleidingen) & 23.3 & - \\
\hline
\end{tabular}

Bron: ROA 
Tabel 4.10

Indicator Toekomstperspectieven op de arbeidsmarkt voor schoolverlaters (ITA) en Indicator Toekomstige Knelpunten in de Personeelsvoorziening (ITKP) per opleidingstype, Overijssel, 2003-2008 (alleen lagere en middelbare opleidingen)

\begin{tabular}{|c|c|c|c|c|}
\hline Opleidingstype & ITA & Typering & ITKP & Typering \\
\hline Basisonderwijs & 1.01 & redelijk & 1.2 & geen \\
\hline VMBO theorie & 0.97 & goed & 0.97 & groot \\
\hline VMBO landbouw en natuurlijke omgeving & 1.11 & matig & 1.47 & geen \\
\hline VMBO bouwtechniek & 1.00 & goed & 1.00 & groot \\
\hline VMBO installatietechniek & & redelijk & & vrijwel geen \\
\hline VMBO mechanische techniek & 0.98 & goed & 1.12 & vrijwel geen \\
\hline VMBO fijnmechanische techniek & & zeer goed & & vrijwel geen \\
\hline VMBO motorvoertuigentechniek & 1.00 & goed & 1.28 & geen \\
\hline VMBO elektrotechniek & 0.98 & goed & 1.03 & enige \\
\hline VMBO grafische techniek & & zeer goed & & vrijwel geen \\
\hline VMBO brood en banket & & matig & & geen \\
\hline VMBO horeca en levensmiddelentechniek & 1.04 & redelijk & 1.06 & vrijwel geen \\
\hline VMBO vervoer & 1.06 & matig & 1.06 & vrijwel geen \\
\hline VMBO administratie, handel en textiel & 1.17 & slecht & 1.45 & geen \\
\hline VMBO verzorging & 1.08 & matig & 1.08 & vrijwel geen \\
\hline VMBO beveiliging & & slecht & & geen \\
\hline HAVO/VWO & 1.06 & matig & 1.06 & vrijwel geen \\
\hline MBO voeding, natuur en milieu & 0.99 & goed & 0.99 & groot \\
\hline MBO groene ruimte & 1.01 & redelijk & 1.01 & enige \\
\hline MBO laboratorium & & goed & & groot \\
\hline MBO bouw & 0.92 & goed & 0.92 & groot \\
\hline MBO grond-, weg- en waterbouw & 1.03 & redelijk & 1.04 & enige \\
\hline MBO installatietechniek & 1.09 & matig & 1.10 & vrijwel geen \\
\hline MBO werktuigbouw en mechanische techniek & 0.92 & goed & 0.98 & groot \\
\hline MBO fijnmechanische techniek & & matig & & geen \\
\hline MBO motorvoertuigentechniek en tweewielers & 1.14 & matig & 1.14 & vrijwel geen \\
\hline MBO vliegtuigtechniek & & zeer goed & & groot \\
\hline MBO operationele techniek & & slecht & & geen \\
\hline MBO elektrotechniek & 0.99 & goed & 1.01 & enige \\
\hline MBO grafische techniek & 1.08 & matig & 1.27 & geen \\
\hline MBO procestechniek & & goed & & groot \\
\hline MBO brood en banket & & redelijk & & vrijwel geen \\
\hline MBO levensmiddelentechniek/vleesverwerking & 0.89 & goed & 0.89 & groot \\
\hline MBO vervoer & 1.04 & redelijk & 1.04 & enige \\
\hline MBO dokters-, tandarts- en dierenartsassistent & & redelijk & & enige \\
\hline MBO apothekersassistent & & zeer goed & & zeer groot \\
\hline MBO verpleging & 0.94 & goed & 0.94 & groot \\
\hline MBO gezondheidstechniek & & zeer goed & & zeer groot \\
\hline MBO sociaal-pedagogisch en welzijn & 1.26 & slecht & 1.26 & geen \\
\hline $\mathrm{MBO}$ verzorging & 1.12 & matig & 1.14 & vrijwel geen \\
\hline MBO uiterlijke verzorging & 0.93 & goed & 0.93 & groot \\
\hline MBO horeca & 0.94 & goed & 0.94 & groot \\
\hline MBO beweging en therapie & & goed & & groot \\
\hline MBO administratie en logistiek & 0.96 & goed & 0.96 & groot \\
\hline MBO handel & 1.06 & matig & 1.09 & vrijwel geen \\
\hline MBO secretariaat & 1.00 & goed & 1.00 & groot \\
\hline MBO toerisme en recreatie & & redelijk & & enige \\
\hline MBO facilitaire dienstverlening & 1.16 & slecht & 1.19 & geen \\
\hline MBO ICT & 1.18 & slecht & 1.18 & geen \\
\hline MBO geld, bank en belastingen & & redelijk & & geen \\
\hline MBO verzekeringswezen & & slecht & & geen \\
\hline MBO openbare orde en veiligheid & 0.89 & goed & 0.89 & groot \\
\hline
\end{tabular}

Bron: ROA 
Tabel 4.11

Conjunctuurgevoeligheid per opleidingstype

Opleidingstype

Conjunctuur-

gevoeligheid

Typering

BASISONDERWIJS

Basisonderwijs

0.82 gemiddeld

VMBO

VMBO Theorie

VMBO theorie

$0.74 \quad$ laag

VMBO Landbouw en natuurlijke omgeving

VMBO landbouw en natuurlijke omgeving

gemiddeld

VMBO Techniek

VMBO bouwtechniek

VMBO installatietechniek

VMBO mechanische techniek

gemiddeld

VMBO fijnmechanische techniek

gemiddeld

VMBO voertuigentechniek

0.79

0.76

VMBO elektrotechniek

0.86

VMBO grafische techniek

VMBO brood en banket

0.72

VMBO transport en logistiek

gemiddeld

gemiddeld

gemiddeld

hoog

laag

laag

VMBO Economie

VMBO administratie, handel en mode

laag

VMBO consumptief en levensmiddelentechniek

gemiddeld

VMBO Zorg en welzijn

VMBO (uiterlijke) verzorging

gemiddeld

VMBO Beveiliging

VMBO beveiliging

0.57

erg laag

\section{HAVO/VWO, MBO}

\section{HAVO/VWO}

HAVO/VWO

laag

MBO Landbouw en natuurlijke omgeving

$M B O$ voeding, natuur en milieu

MBO groene ruimte

MBO Techniek

MBO laboratorium

MBO bouw

MBO grond-, weg- en waterbouw

MBO installatietechniek

MBO werktuigbouw en mechanische techniek

MBO fijnmechanische techniek

MBO motorvoertuigentechniek en tweewielers

MBO vliegtuigtechniek

MBO operationele techniek

MBO elektrotechniek

MBO grafische techniek

0.98

MBO procestechniek

MBO brood en banket

MBO levensmiddelentechniek/ vleesverwerking

hoog

gemiddeld

laag

laag

laag

laag

gemiddeld

gemiddeld

hoog

gemiddeld

gemiddeld

gemiddeld

hoog 
Tabel 4.11 (vervolg)

Conjunctuurgevoeligheid per opleidingstype

Opleidingstype

Conjunctuur-

Typering

gevoeligheid

MBO Dienstverlening en gezondheidszorg

MBO dokters-, tandarts- en dierenartsassistent

MBO apothekersassistent

$M B O$ verpleging

MBO gezondheidstechniek

MBO sociaal-pedagogisch en welzijn

$M B O$ verzorging

MBO uiterlijke verzorging

MBO horeca

MBO beweging en therapie

1.15 erg hoog

0.66 laag

1.12 erg hoog

0.66 laag

0.81 gemiddeld

1.05 hoog

0.95 hoog

0.97 hoog

MBO Economie

MBO administratie en logistiek $\quad 0.68$

MBO handel $\quad 0.79$

MBO secretariaat $\quad 0.65$

MBO toerisme en recreatie $\quad 0.68$

MBO facilitaire dienstverlening $\quad 0.79$

MBO ICT $\quad 0.65$

MBO geld, bank en belastingen $\quad 0.74$

$\begin{array}{ll}\text { MBO verzekeringswezen } & 0.70\end{array}$

erg laag

$M B O$ Openbare orde en veiligheid

MBO openbare orde en veiligheid

$0.70 \quad$ laag

HBO

HBO Onderwijs en tolk en vertaler

HBO lerarenopleiding basisonderwijs $\quad 0.59$

HBO lerarenopleiding talen $\quad 0.74$

HBO lerarenopleiding natuur en techniek $\quad 0.74$

HBO lerarenopleiding economie en maatschappij 0.73

HBO lerarenopleiding lichamelijke opvoeding 0.57

HBO lerarenopleiding medisch en verzorging $\quad 0.76$

HBO lerarenopleiding expressie $\quad 0.77$

HBO tolk en vertaler 0.79

laag

gemiddeld

laag

laag

gemiddeld

erg laag

gemiddeld

laag

HBO Landbouw

$\mathrm{HBO}$ landbouw en veeteelt

$0.80 \quad$ gemiddeld

HBO milieukunde en levensmiddelentechnologie

0.91 hoog

HBO Techniek

HBO laboratorium

HBO bouwkunde

HBO civiele techniek

$\mathrm{HBO}$ werktuigbouwkunde

0.66

0.96

1.13

0.79

0.78

HBO elektrotechniek

0.85

HBO informatica

0.87

HBO chemische technologie

0.72

erg laag

gemiddeld

laag

laag

erg laag

gemiddeld gemiddeld

HBO vervoer en logistiek

laag

hoog

erg hoog

gemiddeld

gemiddeld

gemiddeld

gemiddeld

HBO Paramedisch

$\mathrm{HBO}$ verpleegkunde

0.71

laag

(fysio)therapie

0.59

laag

$\mathrm{HBO}$ voeding

$\mathrm{HBO}$ radiologie

erg laag

erg laag

0.62 erg laag 
Tabel 4.11 (vervolg)

Conjunctuurgevoeligheid per opleidingstype

Opleidingstype

Conjunctuur-

Typering

gevoeligheid

\author{
HBO Economie \\ HBO accountancy en bedrijfseconomie \\ HBO commerciële economie \\ $\mathrm{HBO}$ toerisme en recreatie \\ HBO recht en bestuur \\ HBO secretariaat \\ HBO bedrijfskunde \\ HBO Sociaal-cultureel \\ HBO communicatie en journalistiek \\ HBO maatschappelijk werk en hulpverlening \\ HBO personeel en arbeid \\ HBO bibliotheek en documentatie \\ HBO Kunst \\ HBO uitvoerende en beeldende kunsten \\ HBO Openbare orde en veiligheid \\ $\mathrm{HBO}$ openbare orde en veiligheid
}

$0.88 \quad$ gemiddeld

0.85

0.75

0.92

0.73

gemiddeld

hoog

laag

gemiddeld

0.97 hoog

0.88 gemiddeld

gemiddeld

$0.89 \quad$ gemiddeld

0.76

gemiddeld

wo

WO Letteren en theologie

WO letteren

WO theologie

1.09 erg hoog

0.65 erg laag

WO Landbouw en milieukunde

WO landbouw en milieukunde

1.01 hoog

WO Techniek

WO wiskunde en natuurwetenschappen

WO bouwkunde

WO civiele techniek

WO werktuigbouwkunde

WO elektrotechniek

WO informatica en bestuurlijke informatiekunde

0.94

0.96

0.98

0.94

0.94

1.13

(a)

WO Medisch

WO (dier)geneeskunde

WO tandheelkunde

WO farmacie en medische biologie

$\begin{array}{ll}0.46 & \text { erg laag } \\ 0.40 & \text { erg laag }\end{array}$

0.77 gemiddeld

WO Economie

WO econom(etr)ie

WO bedrijfskunde

WO accountancy en belastingen

WO rechten en bestuurskunde

1.08 erg hoog

1.05 erg hoog

1.41 erg hoog

1.29 erg hoog

WO Sociaal-cultureel

WO sociale wetenschappen

1.11 erg hoog

WO Kunst

WO kunstwetenschappen

$0.86 \quad$ gemiddeld 
Tabel 4.12

Uitwijkmogelijkheden naar verschillende beroepsgroepen per opleidingstype, Overijssel, gemiddelde 2001-2002

Opleidingstype

Spreidings-

Typering

index

BASISONDERWIJS

Basisonderwijs

21.10 erg hoog

VMBO

VMBO Theorie

VMBO theorie

erg hoog

VMBO Landbouw en natuurlijke omgeving

VMBO landbouw en natuurlijke omgeving

gemiddeld

VMBO Techniek

VMBO bouwtechniek

VMBO installatietechniek

VMBO mechanische techniek

VMBO fijnmechanische techniek

VMBO voertuigentechniek

VMBO elektrotechniek

VMBO grafische techniek

VMBO brood en banket

VMBO transport en logistiek

5.50

11.59

9.35

8.02

13.03

11.56

14.68

2.33

laag

gemiddeld

hoog

gemiddeld

gemiddeld

hoog

hoog

hoog

VMBO Economie

VMBO administratie, handel en mode

16.10

erg laag

VMBO consumptief en levensmiddelentechniek

14.28

hoog

VMBO Zorg en welzijn

VMBO (uiterlijke) verzorging

gemiddeld

VMBO Beveiliging

VMBO beveiliging

laag

\section{HAVO/VWO, MBO}

\section{HAVONWO \\ HAVO/VWO}

erg hoog

MBO Landbouw en natuurlijke omgeving

$\mathrm{MBO}$ voeding, natuur en milieu

$\mathrm{MBO}$ groene ruimte

MBO Techniek

MBO laboratorium

MBO bouw

laag

MBO grond-, weg- en waterbouw

MBO installatietechniek

MBO werktuigbouw en mechanische techniek

MBO fijnmechanische techniek

8.62

3.95

MBO motorvoertuigentechniek en tweewielers

MBO vliegtuigtechniek

MBO operationele techniek

5.60

MBO elektrotechniek

MBO grafische techniek

8.13

MBO procestechniek

3.85

MBO brood en banket

MBO levensmiddelentechniek/ vleesverwerking 
Tabel 4.12 (vervolg)

Uitwijkmogelijkheden naar verschillende beroepsgroepen per opleidingstype, Overijssel, gemiddelde 2001-2002

Opleidingstype

Spreidings-

Typering

index

MBO Dienstverlening en gezondheidszorg

MBO dokters-, tandarts- en dierenartsassistent

MBO apothekersassistent

2.55 erg laag

$\mathrm{MBO}$ verpleging

1.75

3.48

MBO gezondheidstechniek

1.99

MBO sociaal-pedagogisch en welzijn

10.27

$M B O$ verzorging

7.12

MBO uiterlijke verzorging

3.12

9.73

MBO horeca

9.73
8.74

erg laag

MBO beweging en therapie

laag

erg laag

gemiddeld

gemiddeld

laag

gemiddeld

gemiddeld

MBO Economie

MBO administratie en logistiek

MBO handel $\quad 15.75$

MBO secretariaat

15.75
3.47

3.47

MBO toerisme en recreatie

5.93
19.07

$\mathrm{MBO}$ facilitaire dienstverlening

MBO ICT

4.99

MBO geld, bank en belastingen

6.75

$\mathrm{MBO}$ verzekeringswezen

3.62

gemiddeld

hoog

laag

gemiddeld

erg hoog

laag

gemiddeld

laag

MBO Openbare orde en veiligheid

$\mathrm{MBO}$ openbare orde en veiligheid

gemiddeld

HBO

HBO Onderwijs en tolk en vertaler

HBO lerarenopleiding basisonderwijs $\quad 2.06$

HBO lerarenopleiding talen $\quad 4.42$

HBO lerarenopleiding natuur en techniek

HBO lerarenopleiding economie en maatschappij

HBO lerarenopleiding lichamelijke opvoeding 3.24

HBO lerarenopleiding medisch en verzorging

HBO lerarenopleiding expressie $\quad 7.07$

HBO tolk en vertaler 11.83

erg laag

laag

gemiddeld

erg hoog

laag

gemiddeld

gemiddeld

hoog

HBO Landbouw

$\mathrm{HBO}$ landbouw en veeteelt

8.87

HBO milieukunde en levensmiddelentechnologie

gemiddeld

HBO Techniek

$\mathrm{HBO}$ laboratorium

HBO bouwkunde

10.65

4.76

HBO civiele techniek

7.88

$\mathrm{HBO}$ werktuigbouwkunde

13.53

HBO elektrotechniek

11.42

HBO informatica

2.50

HBO chemische technologie

10.75

$\mathrm{HBO}$ vervoer en logistiek

hoog

HBO Paramedisch

$\mathrm{HBO}$ verpleegkunde

HBO (fysio)therapie

$\mathrm{HBO}$ voeding

$\mathrm{HBO}$ radiologie

$\begin{array}{ll}3.70 & \text { laag } \\ 1.98 & \text { erg laag } \\ 5.20 & \text { gemiddeld } \\ 2.37 & \text { erg laag }\end{array}$


Tabel 4.12 (vervolg)

Uitwijkmogelijkheden naar verschillende beroepsgroepen per opleidingstype, Overijssel, gemiddelde 2001-2002

$\begin{array}{lrl}\text { Opleidingstype } & \begin{array}{c}\text { Spreidings- } \\ \text { index }\end{array} & \text { Typering }\end{array}$

HBO Economie

HBO accountancy en bedrijfseconomie

HBO commerciële economie $\quad 5.24$

HBO toerisme en recreatie

HBO recht en bestuur

HBO secretariaat $\quad 5.52$

$\begin{array}{ll}\text { HBO bedrijfskunde } & 20.06\end{array}$

gemiddeld

gemiddeld

gemiddeld

hoog

gemiddeld

erg hoog

HBO Sociaal-cultureel

HBO communicatie en journalistiek

7.23

HBO maatschappelijk werk en hulpverlening

5.67

HBO personeel en arbeid

HBO bibliotheek en documentatie

gemiddeld

gemiddeld

HBO Kunst

HBO uitvoerende en beeldende kunsten

6.69 gemiddeld

HBO Openbare orde en veiligheid

HBO openbare orde en veiligheid

gemiddeld

Wo

WO Letteren en theologie

WO letteren

WO theologie

15.05 hoog

$3.94 \quad$ laag

WO Landbouw en milieukunde

WO landbouw en milieukunde

$19.32 \quad$ erg hoog

WO Techniek

WO wiskunde en natuurwetenschappen $\quad 16.86$ hoog

2.34 erg laag

WO civiele techniek

6.44 gemiddeld

WO werktuigbouwkunde

$\begin{aligned} 11.39 & \text { gemiddeld } \\ 9.64 & \text { gemiddeld }\end{aligned}$

WO elektrotechniek

WO informatica en bestuurlijke informatiekunde

4.53 laag

WO Medisch

WO (dier)geneeskunde

WO tandheelkunde

1.27 erg laag

WO farmacie en medische biologie

1.12 erg laag

WO Economie

WO econom(etr)ie

WO bedrijfskunde

4.57 laag

WO accountancy en belastingen

12.78 hoog

WO rechten en bestuurskunde

hoog

4.37 laag

3.44 laag

WO Sociaal-cultureel

WO sociale wetenschappen

14.30 hoog

WO Kunst

WO kunstwetenschappen

13.09

hoog 
Tabel 4.13

Substitutiemogelijkheden tussen mensen met uiteenlopende opleidingsachtergronden per beroepsgroep, Overijssel, gemiddelde 2001-2002

\begin{tabular}{lcc}
\hline Opleidingstype & $\begin{array}{c}\text { Spreidings- } \\
\text { index }\end{array}$ & Typering \\
\hline
\end{tabular}

\section{PEDAGOGISCHE BEROEPEN}

Leraar basisonderwijs

Docenten exacte, medische en verzorgende vakken (2e graads) 6.76 gemiddeld Docenten exacte, medische en verzorgende vakken (1e graads) 3.02

Docenten landbouw en techniek (2e graads)

Docenten landbouw en techniek (1e graads)

erg laag

Docenten economisch-administratieve vakken (2e graads)

laag

gemiddeld

Docenten economisch-administratieve vakken (1e graads) 6.22

Docenten talen en expressie

Docenten letteren (1e graads) 3.97

Docenten sociale vakken (2e graads)

Docenten sociale vakken (1e graads)

Docenten 2e graads zonder specialisatie

Docent 1e graads zonder specialisatie $\quad 6.16$

Onderwijskundig medewerkers $\quad 15.59$

Onderwijskundigen en pedagogen $\quad 8.72$

Rij-instructeurs

Zweminstructeurs $\quad 6.74$

$\begin{array}{ll}\text { Sportinstructeurs } & 7.82\end{array}$

gemiddeld

gemiddeld

laag

laag

laag

erg laag

gemiddeld

gemiddeld

hoog

gemiddeld

laag

gemiddeld

gemiddeld

\section{CULTURELE BEROEPEN}

$\begin{array}{lr}\text { Tolken, vertalers en schrijvers } & 7.38\end{array}$

Bibliotheekassistenten $\quad 13.39$

Bibliothecarissen $\quad 3.07$

Grafisch ontwerpers $\quad 5.29$

Kunstenaars $\quad 5.62$

Geestelijk verzorgers $\quad 1.89$

Geestelijken $\quad 1.35$

$\begin{array}{ll}\text { Journalisten } & 7.77\end{array}$

Taalkundigen $\quad 6.26$

gemiddeld

hoog

erg laag

laag

laag

erg laag

erg laag

gemiddeld

gemiddeld

\section{AGRARISCHE BEROEPEN}

Agrarische hulparbeiders

Agrarische arbeiders

Agrarische vakkrachten

Milieuhygiënisten en agrarisch vertegenwoordigers $\quad 11.3$

Landbouwkundigen

Landbouwmachinebestuurders en vissers

Agrarische bedrijfshoofden

TECHNISCHE, AMBACHTS- EN INDUSTRIEBEROEPEN

Productiemedewerkers

Laboratorium-assistenten

Laboranten

Technisch analisten

Natuurwetenschappers

Conciërges

Hoofden technische dienst

Werktuigbouwkundigen

Bouwvakkers

Aannemers en installateurs 
Tabel 4.13 (vervolg)

Substitutiemogelijkheden tussen mensen met uiteenlopende opleidingsachtergronden per beroepsgroep, Overijssel, gemiddelde 2001-2002

\begin{tabular}{lrr}
\hline Opleidingstype & $\begin{array}{r}\text { Spreidings- } \\
\text { index }\end{array}$ & Typering \\
\hline
\end{tabular}

Weg- en waterbouwkundige arbeiders

6.93

gemiddeld

Weg- en waterbouwkundige vakkrachten

11.58

hoog

Weg- en waterbouwkundig ontwerpers en projectleiders

5.72

Metaalarbeiders

laag

Bankwerkers en lassers

7.8

iddeld

Bedrijfshoofden metaalbewerking $\quad 14.29$

Assembleurs $\quad 10.56$

Monteurs $\quad 12.71$

Werktuigbouwkundig ontwerpers en hoofden technische dienst $\quad 8.81$

Elektronicamonteurs $\quad 4.73$

Monteurs en controleurs elektrotechnische producten $\quad 7.29$

Elektromonteurs

Elektrotechnisch ontwerpers en bedrijfshoofden $\quad 5.1$

Elektrotechnici 6.3

Grafisch productiepersoneel $\quad 6.44$

Grafische vakkrachten $\quad 5.95$

Mechanisch operators $\quad 9.87$

Procesoperators 13.66

$\begin{array}{ll}\text { Procestechnologen } & 17.18\end{array}$

Materiaalkundigen $\quad 9.89$

$\begin{array}{ll}\text { Confectie-arbeiders } & 7.41\end{array}$

Schoen- en kleermakers $\quad 6.45$

gemiddeld

hoog

gemiddeld

hoog

gemiddeld

laag

gemiddeld

laag

laag

gemiddeld

gemiddeld

laag

gemiddeld

hoog

erg hoog

gemiddeld

gemiddeld

TRANSPORT BEROEPEN

Laders en lossers $\quad 11.88$

12.75

$\begin{array}{lr}\text { Schippers en conducteurs } & 9.36 \\ \text { Vliegers, scheepskapiteins en leidinggevenden transport } & 8.14\end{array}$

Stewards

hoog

hoog

gemiddeld

gemiddeld

\section{MEDISCHE EN PARAMEDISCHE BEROEPEN}

Verpleeghulpen en leerling-verpleegkundigen

Verplegenden en doktersassistenten

Therapeuten en verpleegkundigen

Apothekersassistenten en medisch laboranten

Medisch analisten

Apothekers

11.23

gemiddeld

Afdelingshoofden zorginstelling

gemiddeld

erg laag

gemiddeld

erg laag

gemiddeld

laag

erg laag

hoog

\section{ECONOMISCH-ADMINISTRATIEVE BEROEPEN}

Kantoorhulpen, inpakkers en colporteurs

Ondersteunende administratieve hulpkrachten

Bedrijfshoofden

laag

Economen

8.09

Productieplanners

Organisatie-adviseurs

Organisatiedeskundigen

Receptionisten en administratieve employés

Boekhouders en secretaresses

11.81

Assistent accountants

Accountants

Verzekeringsagenten

Commercieel employés 
Tabel 4.13 (vervolg)

Substitutiemogelijkheden tussen mensen met uiteenlopende opleidingsachtergronden per beroepsgroep, Overijssel, gemiddelde 2001-2002

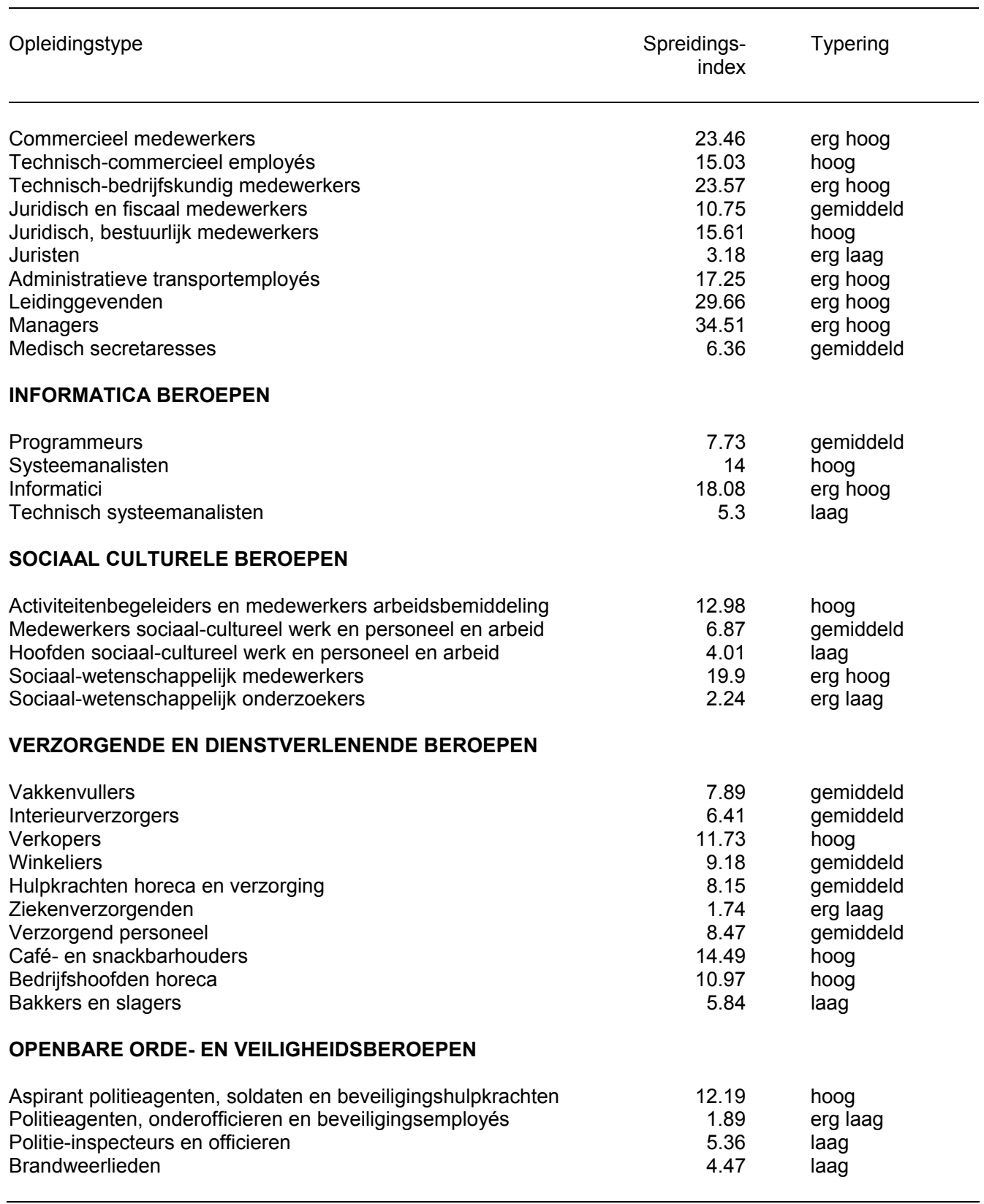





\section{$5 \quad$ Classificaties}



Overzicht van opleidingstypen

Opleidingsniveau

Opleidingscategorie

$\mathrm{Nr}$ Opleidingstype sol

Basisonderwijs

001 Basisonderwijs

00000-20199

VMBO, VMBO theorie

VMBO theorie

$002 \quad$ VMBO theorie

30100-30199

VMBO Landbouw en natuurlijke omgeving

003 VMBO landbouw en natuurlijke omgeving

$30637,32100-32999$

VMBO Techniek

VMBO bouwtechniek

VMBO installatietechniek

VMBO mechanische techniek

VMBO fijnmechanische techniek

VMBO voertuigentechniek

VMBO elektrotechniek

VMBO grafische techniek

VMBO brood en banket

VMBO transport en logistiek

VMBO techniek overig

$33610-33615,33617-33629$

33616

$33631,33633,33638$

33635

33641

33650-33659

33660-33669

33676

34100-34399

33100-33199, 33642-33649,

33670-33672, 33674-33675

33678-33684, 33686-33699

VMBO Economie

014 VMBO administratie, handel en textiel

33673, 33685, 36110-36699

015 VMBO consumptief en levensmiddelentechniek

$33677,34430,38140,38340$

VMBO Verzorging

016 VMBO (uiterlijke) verzorging

$30667,30671,35100-35499$,

37100-37199, 38100-38139,

$38180-38199,38330$

VMBO Openbare orde en veiligheid

$017 \quad$ VMBO beveiliging

39100-39399

VMBO Overig

VMBO overig

$30690,31100-31199,31610$,

$38430,38600-38699$,

39800-39999

\section{MBO, HAVO/VWO}

HAVO/VWO

019 HAVONWO

40100-40199

MBO Landbouw en natuurlijke omgeving

020 MBO voeding, natuur en milieu

42110-42129, 42150-42169

42188-42199, 42220-42999

MBO groene ruimte

$42130,42175,42183$

MBO Techniek

MBO laboratorium

43100-43199, 45210-45219

MBO bouw

MBO grond-, weg- en waterbouw

$43611-43615,43618-43619$

$43811-43815,43818-43819$

43623-43625, 43823-43825

025 MBO installatietechniek

43616, 43816 


\section{Overzicht van opleidingstypen (vervolg)}

Opleidingsniveau

Opleidingscategorie

Nr. Opleidingstype

$\mathrm{SOl}$

$026 \mathrm{MBO}$ werktuigbouw \& mechanische techniek

42210, 43631, 43633,

43638, 43643, 43647-43648,

$43833,43838,43843$

43847-43848,

44231, 44250-44299

027 MBO fijnmechanische techniek

$43635,43835,45280$

028 MBO motorvoertuigentechniek en tweewielers

$43641,43649,43841$

MBO vliegtuigtechniek

MBO operationele techniek

43645

MBO elektrotechniek

43646

MBO grafische techniek

$43650-43659,43850-43859$

43660-43669, 43867-43869

$43674,43675,43678,43679$

$43874,43875,43878,43879$

MBO brood en banket

43676,43876

MBO levensmiddelentechniek

vleesverwerking

43677,43877

40657, 44100-44199, 44210,

44238-44241, 44248,

44300-44999

$43671-43673,43682$,

MBO techniek overig

43688-43699, 43888-43999

MBO Dienstverlening en gezondheidszorg

MBO dokters-, tandarts- en dierenartsassistent

MBO apothekersassistent

$45118,45138,45160$

45220

$\mathrm{MBO}$ verpleging

45120, 45380,

45230-45239

47100-47199

MBO sociaal-pedagogisch en welzijn

41610, 45430, 45480, 48110-48129,

$48180-48199,48320$

48130,48330

48140,48340

40667, 45140-45159,

45161-45179, 45181-45199,

$45240-45249,45410,45900$

MBO Economie

$047 \quad \mathrm{MBO}$ administratie en logistiek

$46110,46133,46138,46141$

46148, 46180-46199,

$46600-46629,46690$

$43617,43685,43817,43885$

$46143,46150-46159,46280$

$45180,45310,46131$

MBO secretariaat

MBO toerisme en recreatie

MBO facilitaire dienstverlening

46142

$46120-46129,46220$

46135

46145,46630

MBO geld, bank en belastingen

$\mathrm{MBO}$ verzekeringswezen

46146

MBO Openbare orde en veiligheid

055 MBO openbare orde en veiligheid

49100-49799

MBO Overig

MBO overig

40617-40656, 40658,

40670-40699,

41110-41199, 46240

48400-48699, 49800-49999 


\section{Overzicht van opleidingstypen (vervolg)}

Opleidingsniveau

Opleidingscategorie

Nr. Opleidingstype

SOI

HBO

HBO Onderwijs en tolk en vertaler

057 HBO lerarenopleiding basisonderwijs

HBO lerarenopleiding talen

50690-50699,

$60611-60617,60692$

$50620-50625,50628,50629$

60620-60625, 60628, 60629,

$70621-70625,70628,70629$

50630-50659, 60630-60659,

70630-70635

060 HBO lerarenopleiding economie en maatschappij 50626, 50627, 50660-50666,

$57181,60626,60627,60660-60666,70626$,

$70627,70660-70666$

061 HBO lerarenopleiding lichamelijke opvoeding

50667,60667

HBO lerarenopleiding medisch en verzorging

$50670-50679,60670-60679$

HBO lerarenopleiding expressie

$50680-50689,60680-60689,70680-70689$

$064 \quad \mathrm{HBO}$ tolk en vertaler

$51100-51199$

HBO Landbouw

$065 \quad \mathrm{HBO}$ landbouw en veeteelt

52110,52158

HBO milieukunde en levensmiddelentechnologie 52128-52130, 52171-52299, 52900, 53677, 53678

HBO Techniek

$\mathrm{HBO}$ laboratorium

HBO bouwkunde

HBO civiele techniek

HBO werktuigbouwkunde

HBO elektrotechniek

HBO informatica

$\mathrm{HBO}$ chemische technologie

HBO vervoer en logistiek

HBO Paramedisch

$\mathrm{HBO}$ verpleegkunde

HBO (fysio)therapie

HBO voeding

$\mathrm{HBO}$ radiologie

HBO paramedisch overig

$53140,53149,53160,55210,55220$

$53610-53619,53810-53819$

$53620-53629,53820-53829$

53631-53649, 53830-53849

53110-53139, 53150, 53170-53190, 53650-53651,

$53653-53655,53682,53683$

53652,56135

$53670-53676$

$54100-54999$

55120,55380

$55140-55149,55151,55153,55180,55238$

55420,58180

$55241-55243$

55110-55119, 55130-55133, 55160, 55190-55199 $55231,55248,55280,55480$

HBO Economie

080 HBO accountancy en bedriffseconomie

$081 \mathrm{HBO}$ commerciële economie

082 HBO toerisme en recreatie

083 HBO recht en bestuur

084 HBO secretariaat

HBO bedrijfskunde

$56110,56133,56138,56210,56240,56249$,

56630

$56143-56180$

56142

$56611-56629,56690$

55310,56131

$52310,52350,52380,56120,56220$

HBO Sociaal-cultureel

HBO communicatie en journalistiek

56141,57120

HBO maatschappelijk werk en hulpverlening

HBO personeelswerk

$51610,57111,57115-57119,57188-57199$

57113

57130

$57141,57143,57145-57165$ 


\section{Overzicht van opleidingstypen (vervolg)}

Opleidingsniveau

Opleidingscategorie

Nr. Opleidingstype

SOI

HBO Kunst

091 HBO uitvoerende en beeldende kunsten

$58610-58640,58680-58699,68610$

HBO Openbare orde en veiligheid

092

$\mathrm{HBO}$ openbare orde en veiligheid

$59100-59499$

HBO Overig

HBO overig

$53685-53699,53868,53885$,

53900,56190-56199,

$58110-58125,58190,58340,58900-58999$,

WO

59900-59999

WO Letteren en theologie

094 WO letteren

095 WO theologie

WO Landbouw en milieukunde

096 WO landbouw en milieukunde

61100-61199, 71100-71199

61610,71610

62110-62130, 62158, 62170-62180, 62182-62189, 62200-62999, 72175

WO Techniek

097 WO wiskunde en natuurwetenschappen

63110-63199, 63631, 63670-63688, 73110-73199,

73674,73675

$63613-63618,63818,73618$

WO bouwkunde

WO civiele techniek

WO werktuigbouwkunde

$63623-63625,73623$

62181, 63643-63649,

73645-73648

63650-63651, 63653-63659, 72181, 73650-73651 $73653-73659$

WO elektrotechniek

$63652,66135,73652,76135$

WO Medisch

WO (dier)geneeskunde

WO tandheelkunde

WO farmacie en medische biologie

WO Economie

WO econom(etr)ie

WO bedrijfskunde

WO accountancy en belastingen

WO rechten en bestuurskunde

$65111,65160,75111,75160$

65131,75131

65200-65299, 75200-75299

$66110,66141-66219,66221-66240,76110$,

$76141-76219$

$66120,66220,76120$

$66133,66630,76133,76630$

$66118,66610-66629$

66631-66699, 76118, 76610-76629

WO Sociaal-cultureel

110 WO sociale wetenschappen

65148, 65180-65199, 67120, 67130, 67141-

$67188,68110,68180,75148,75151,75180$,

$77130,77141-77188$

67110-67119, 67190, 77113

WO Kunst

112 WO kunstwetenschappen

WO Overig

68640

$63690,63900,65380,65480,65900,68690$,

69150-69999

Noot: De classificatie die gehanteerd wordt in hoofdstuk 1 van deze Statistische Bijlage wijkt op twee punten licht af van de indeling die hier wordt weergegeven. Het opleidingstype MBO fijnmechanische techniek en laboratium is in hoofdstuk 1 uitgesplitst in MBO Laboratium en MBO fijnmechanische techniek. In plaats van het opleidingstype MBO verpleging en verzorging worden in hoofdstuk 1 twee opleidingstypen - $M B O$ verzorging en $M B O$ verpleging - onderscheiden. 
Beroepsgroepen, volgorde ROA

ROA-beroepsklasse

ROA-nr. SBC ROA-beroepsgroep

\section{PEDAGOGISCHE BEROEPEN}

623 Leraar basisonderwijs

625 Docenten exacte, medische en verzorgende vakken (2e graads)

825 Docenten exacte, medische en verzorgende vakken (1e graads)

626 Docenten landbouw en techniek (2e graads)

826 Docenten landbouw en techniek (1e graads)

631 Docenten economisch-administratieve vakken (2e graads)

831 Docenten economisch-administratieve vakken (1e graads)

633 Docenten talen en expressie

833 Docenten letteren (1e graads)

634 Docenten sociale vakken (2e graads)

834 Docenten sociale vakken (1e graads)

621 Docenten 2 e graads zonder specialisatie

821 Docent 1e graads zonder specialisatie

622 Onderwijskundig medewerkers

822 Onderwijskundigen en pedagogen

427 Rij-instructeurs

234 Zweminstructeurs

434 Sportinstructeurs

\section{CULTURELE BEROEPEN}

$\begin{array}{lll}19 & 752 & \text { Tolken, vertalers en schrijvers } \\ 20 & 553 & \text { Bibliotheekassistenten } \\ 21 & 753 & \text { Bibliothecarissen } \\ 22 & 554 & \text { Grafisch ontwerpers } \\ 23 & 754 & \text { Kunstenaars } \\ 24 & 762 & \text { Geestelijk verzorgers } \\ 25 & 962 & \text { Geestelijken } \\ 26 & 764 & \text { Journalisten } \\ 27 & 964 & \text { Taalkundigen }\end{array}$

\section{AGRARISCHE BEROEPEN}

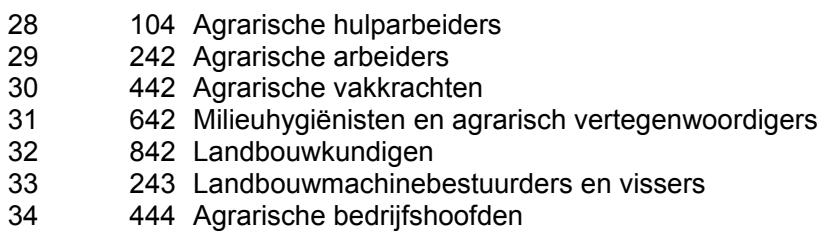

\section{TECHNISCHE, AMBACHTS- EN INDUSTRIEBEROEPEN}

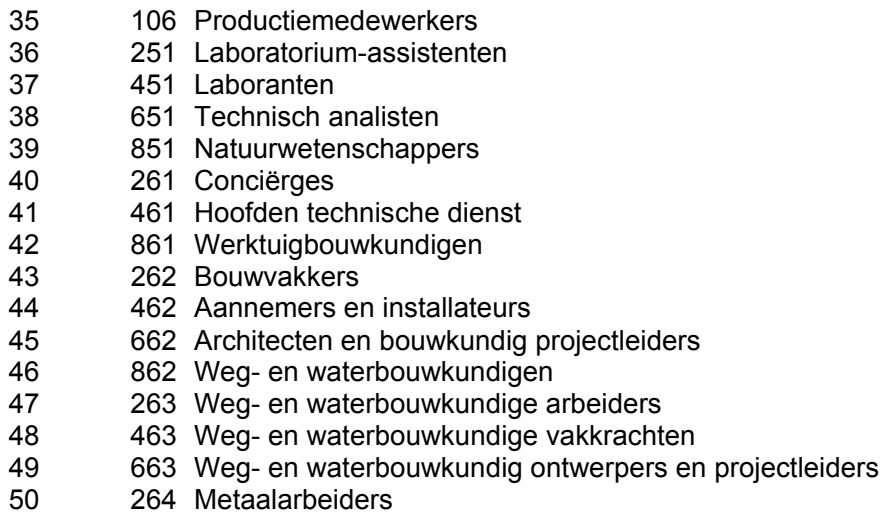




\section{Beroepsgroepen, volgorde ROA (vervolg)}

ROA-beroepsklasse

ROA-nr. SBC ROA-beroepsgroep

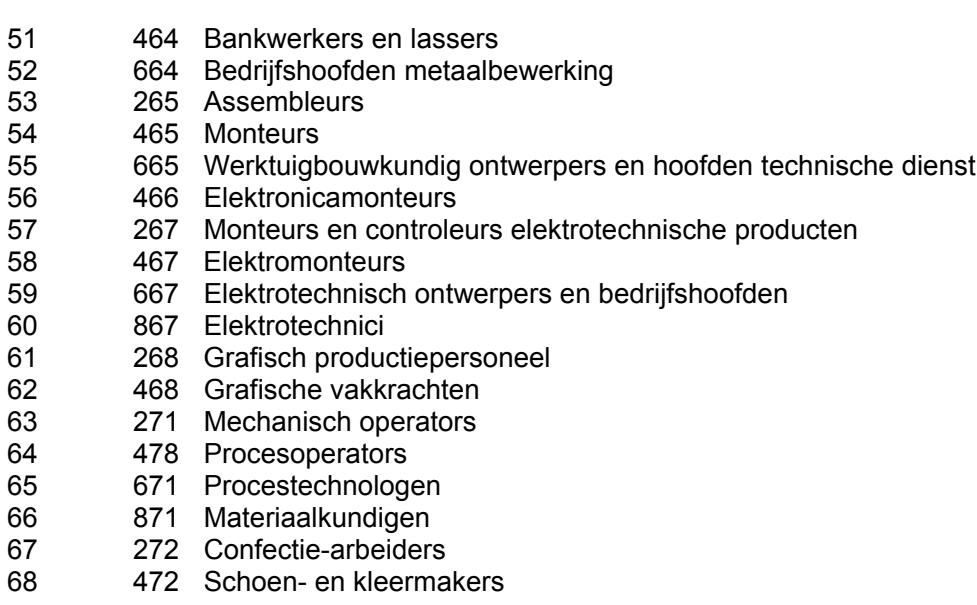

\section{TRANSPORTBEROEPEN}

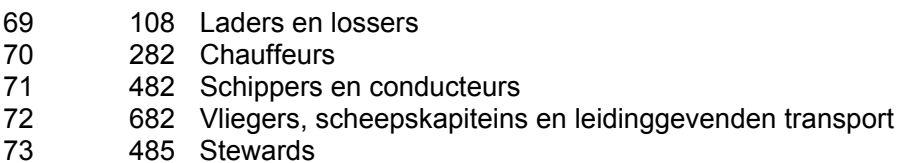

\section{MEDISCHE EN PARAMEDISCHE BEROEPEN}

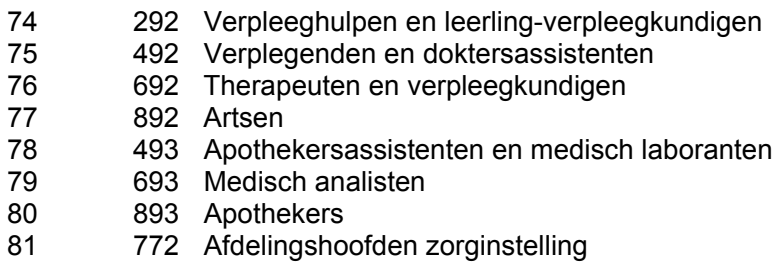

\section{ECONOMISCH-ADMINISTRATIEVE BEROEPEN}

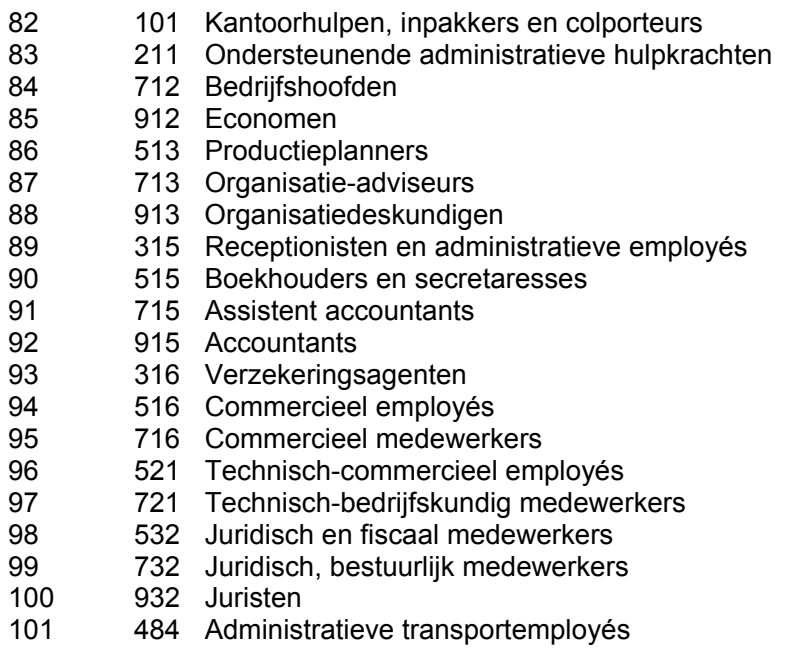


Beroepsgroepen, volgorde ROA (vervolg)

ROA-beroepsklasse

ROA-nr. SBC ROA-beroepsgroep

\begin{tabular}{lll}
\hline 102 & 788 & Leidinggevenden \\
103 & 988 & Managers \\
104 & 494 & Medisch secretaresses
\end{tabular}

\section{INFORMATICA BEROEPEN}

$\begin{array}{lll}105 & 514 & \text { Programmeurs } \\ 106 & 714 & \text { Systeemanalisten } \\ 107 & 914 & \text { Informatici } \\ 108 & 666 & \text { Technisch systeemanalisten }\end{array}$

\section{SOCIAAL-CULTURELE BEROEPEN}

109563 Activiteitenbegeleiders en medewerkers arbeidsbemiddeling

110763 Medewerkers sociaal-cultureel werk en personeel en arbeid

111963 Hoofden sociaal-cultureel werk en personeel en arbeid

112765 Sociaal-wetenschappelijk medewerkers

113965 Sociaal-wetenschappelijk onderzoekers

\section{VERZORGENDE EN DIENSTVERLENENDE BEROEPEN}

$\begin{array}{lll}114 & 112 & \text { Vakkenvullers } \\ 115 & 117 & \text { Interieurverzorgers } \\ 116 & 317 & \text { Verkopers } \\ 117 & 517 & \text { Winkeliers } \\ 118 & 372 & \text { Hulpkrachten horeca en verzorging } \\ 119 & 495 & \text { Ziekenverzorgenden } \\ 120 & 572 & \text { Verzorgend personeel } \\ 121 & 373 & \text { Café- en snackbarhouders } \\ 122 & 573 & \text { Bedrijfshoofden horeca } \\ 123 & 479 & \text { Bakkers en slagers }\end{array}$

\section{OPENBARE ORDE- EN VEILIGHEIDSBEROEPEN}

124342 Aspirant politieagenten, soldaten en beveiligingshulpkrachten

125542 Politieagenten, onderofficieren en beveiligingsemployés

126742 Politie-inspecteurs en officieren

127473 Brandweerlieden 
Beroepsgroepen, volgens SBC '92

$\begin{array}{lll}\text { Nr. } & \text { SBC Beroepsklasse Beroepsgroep (CBS-naam) Beroepsgroep (ROA-naam) }\end{array}$

$\begin{aligned} & \text { ELEMENTAIRE BEROEPEN } \\ 101 & \text { Algemene elementaire beroepen } \\ 104 & \text { Elementaire agrarische beroepen } \\ 106 & \text { Elementaire technische beroepen } \\ 108 & \text { Elementaire transportberoepen } \\ 112 & \text { Elementaire administratieve, commerciële beroepen } \\ 117 & \text { Elementaire verzorgende beroepen } \\ & \\ \mathbf{2 1} & \text { LAGERE NIET-SPECIALISTISCHE BEROEPEN } \\ 211 & \text { Lagere niet-specialistische beroepen }\end{aligned}$

\section{LAGERE DOCENTEN SPORTVAKKEN}

Lagere docenten sportvakken

\section{LAGERE AGRARISCHE BEROEPEN}

242 Lagere algemeen agrarische beroepen

$243 \quad$ Lagere technisch-agrarische beroepen

\section{LAGERE WISKUNDIGE, NATUURWETENSCHAPPELIJKE BEROEPEN}

251 Lagere wiskundige, natuurwetenschappelijke beroepen

\section{LAGERE TECHNISCHE BEROEPEN}

261 Lagere technische beroepen (ongeacht specialisatie)

$262 \quad$ Lagere bouwkundige beroepen

263 Lagere weg-en waterbouwkundige beroepen

264 Lagere metaalkundige beroepen

265 Lagere werktuigbouwkundige beroepen

267 Lagere elektrotechnische beroepen

268 Lagere grafische beroepen

$271 \quad$ Lagere procestechnische beroepen

$272 \quad$ Lagere technische beroepen NEG

\section{LAGERE TRANSPORTBEROEPEN}

282 Lagere algemene transportberoepen
Kantoorhulpen, inpakkers en colporteurs

Agrarische hulparbeiders

Productiemedewerkers

Laders en lossers

Vakkenvullers

Interieurverzorgers

Ondersteunende administratieve hulpkrachten

Zweminstructeurs

Agrarische arbeiders

Landbouwmachinebestuurders en vissers

Laboratorium-assistenten

Conciërges

Bouwvakkers

Weg- en waterbouwkundige arbeiders

Metaalarbeiders

Assembleurs

Monteurs en controleurs elektrotechnische producten

Grafisch productiepersoneel

Mechanisch operators

Confectie-arbeiders

Chauffeurs 
Beroepsgroepen, volgens SBC '92 (vervolg)

\begin{tabular}{|c|c|c|}
\hline Nr. & SBC Beroepsklasse Beroepsgroep (CBS-naam) & Beroepsgroep (ROA-naam) \\
\hline 29 & LAGERE (PARA)MEDISCHE BEROEPEN & \\
\hline 292 & Lagere (para)medische beroepen & Verpleeghulpen en leerling-verpleegkundigen \\
\hline 31 & LAGERE ADMINISTRATIEVE, COMMERCIËLE BEROEPEN ED & \\
\hline 315 & Lagere administratieve beroepen & Receptionisten en administratieve employés \\
\hline 316 & Lagere (technisch-)commerciële beroepen & Verzekeringsagenten \\
\hline 317 & Lagere verkoopberoepen & Verkopers \\
\hline 33 & LAGERE BEVEILIGINGSBEROEPEN & \\
\hline 342 & Lagere beveiligingsberoepen & Aspirant politieagenten, soldaten en beveiligingshulpkrachten \\
\hline 37 & LAGERE VERZORGENDE BEROEPEN & \\
\hline 372 & Lagere algemeen verzorgende beroepen e.d. & Hulpkrachten horeca en verzorging \\
\hline 373 & Lagere commercieel-verzorgende beroepen & Café- en snackbarhouders \\
\hline 42 & MIDDELBARE DOCENTEN TRANSPORT-, SPORTVAKKEN & \\
\hline 427 & Middelbare docenten transportvakken & Rij-instructeurs \\
\hline 434 & Middelbare docenten sportvakken & Sportinstructeurs \\
\hline 44 & MIDDELBARE AGRARISCHE BEROEPEN & \\
\hline 442 & Middelbare (technisch-) agrarische beroepen & Agrarische vakkrachten \\
\hline 444 & Middelbare commercieel-agrarische beroepen & Agrarische bedrijfshoofden \\
\hline 45 & MIDDELBARE WISKUNDIGE, NATUURWETENSCHAPPELIJKE BEROEPEN & \\
\hline 451 & Middelbare wiskundige, natuurwetenschappelijke beroepen & Laboranten \\
\hline 46 & MIDDELBARE TECHNISCHE BEROEPEN & \\
\hline 461 & Middelbare technische beroepen (ongeacht specialisatie) & Hoofden technische dienst \\
\hline 462 & Middelbare bouwkundige beroepen & Aannemers en installateurs \\
\hline 463 & Middelbare weg- en waterbouwkundige beroepen & Weg- en waterbouwkundige vakkrachten \\
\hline 464 & Middelbare metaalkundige beroepen & Bankwerkers en lassers \\
\hline 465 & Middelbare werktuigbouwkundige beroepen e.d. & Monteurs \\
\hline 466 & Middelbare elektrotechnische beroepen (automatisering e.d.) & Elektronicamonteurs \\
\hline
\end{tabular}


Beroepsgroepen, volgens SBC '92 (vervolg)

Nr. $\quad$ SBC Beroepsklasse Beroepsgroep (CBS-naam)

Beroepsgroep (ROA-naam)

Middelbare elektrotechnische beroepen (excl. automatisering)

Middelbare grafische beroepen e.d.

Middelbare procestechnische beroepen

Middelbare procestechnische beroepen

Middelbare technische beroepen NEG

Middelbare technische beveiligingsberoepen

\section{MIDDELBARE TRANSPORTBEROEPEN ED}

Middelbare algemene transportberoepen

Middelbare economisch-administratieve transportberoepen

Middelbare verzorgende transportberoepen

\section{MIDDELBARE (PARA)MEDISCHE BEROEPEN}

Middelbare algemene (para)medische beroepen

Middelbare technisch-(para)medische beroepen

Middelbare economisch-administratieve (para)medische beroepen

Middelbare verzorgend-(para)medische beroepen

\section{COMMERCIELE BEROEPEN ED}

Middelbare bedrijfskundige beroepen

Middelbare administratieve beroepen (automatisering e.d)

Middelbare administratieve beroepen (excl. automatiering)

Middelbare commerciële beroepen

Middelbare verkoopberoepen

Middelbare technisch-, wiskundig-, commerciële, administratieve beroepen

\section{Elektromonteurs}

Grafische vakkrachten

Procesoperators

Bakkers en slagers

Schoen- en kleermakers

Brandweerlieden

Schippers en conducteurs

Administratieve transportemployés

Stewards

Verplegenden en doktersassistenten

Apothekersassistenten en medisch laboranten

Medisch secretaresses

Ziekenverzorgenden

Productieplanners

Programmeurs

Boekhouders en secretaresses

Commercieel employés

Winkeliers

Technisch-commercieel employés

MIDDELBARE JURIDISCHE, BESTUURLIJKE BEVEILIGINGSBEROEPEN

Middelbare juridische, bestuurlijke beroepen

Middelbare beveiligingsberoepen

Juridisch en fiscaal medewerkers

Politieagenten, onderofficieren en beveiligingsemployés

MIDDELBARE TAALKUNDIGE, CULTURELE BEROEPEN

Middelbare taalkundige beroepen e.d.

Bibliotheekassistenten

Grafisch ontwerpers 
Beroepsgroepen, volgens SBC '92 (vervolg)

56 MIDDELBARE BEROEPEN M.B.T. GEDRAG EN MAATSCHAPPIJ

563 Middelbare sociaal-maatschappelijke beroepen e.d.

\section{MIDDELBARE VERZORGENDE BEROEPEN ED.}

Middelbare algemeen verzorgende beroepen

573 Middelbare commercieel-verzorgende beroepen e.d.

\section{HOGERE PEDAGOGISCHE BEROEPEN}

621 Hogere pedagogische beroepen (ongeacht specialisatie)

622 Hogere onderwijskundige, pedagogische beroepen

623 Docenten basisonderwijs, algemeen vormende vakken

625 Docenten exacte, (para)medische, verzorgende vakken $\left(2^{\mathrm{e}}\right.$ en $3^{\mathrm{e}} \mathrm{gr}$ )

626 Docenten agrarische, technische, transportvakken $\left(2^{\mathrm{e}}\right.$ en $3^{\mathrm{e}} \mathrm{gr}$. $)$

631 Docenten economische, administratieve, juridische vakken $\left(2^{\mathrm{e}}\right.$ en $3^{\mathrm{e}} \mathrm{gr}$.)

633 Docenten taalkundige, culturele vakken e.d.

634 Docenten sociale, psychologische vakken ( $2^{\mathrm{e}}$ en $3^{\mathrm{e}} \mathrm{gr}$.)

\section{HOGERE LANDBOUWKUNDIGE BEROEPEN}

$642 \quad$ Hogere landbouwkundige beroepen

\section{HOGERE WISKUNDIGE, NATUURWETENSCHAPPELIJKE BEROEPEN}

651 Hogere wiskundige, natuurwetenschappelijke beroepen

66 HOGERE TECHNISCHE BEROEPEN

662 Hogere bouwkundigen, technische

beveiligingsberoepen

Hogere weg-en waterbouwkundige

Hogere metaalkundige beroepen

Hogere werktuigbouwkundige beroepen e.d.

Hogere elektrotechnische beroepen (automatisering e.d.)

Hogere elektrotechnische beroepen (excl. Automatisering)

Hogere procestechnische beroepen e.d.
Activiteitenbegeleiders en medewerkers arbeidsbemiddeling

Verzorgend personeel

Bedrijfshoofden

Docenten $2^{\mathrm{e}}$ en $3^{\mathrm{e}}$ graads zonder specialisatie

Onderwijskundig medewerkers

Leraar basisonderwijs

Docenten exacte, medische en verzorgende vakken $\left(2^{\mathrm{e}} \mathrm{gr}\right.$.

Docenten landbouw en techniek $\left(2^{\mathrm{e}} \mathrm{gr}\right.$. $)$

Docenten economisch-administratieve vakken $\left(2^{\mathrm{e}} \mathrm{gr}\right.$.

Docenten talen en expressie

Docenten sociale vakken $\left(2^{\mathrm{e}} \mathrm{gr}\right.$.

Milieuhygiënisten en agrarisch vertegenwoordigers

Technisch analisten

Architecten en bouwkundig projectleiders

Weg- en waterbouwkundig ontwerpers en projectleiders

Bedrijfshoofden metaalbewerking

Werktuigbouwkundig ontwerpers en hoofden technische dienst

Technisch systeemanalisten

Elektrotechnisch ontwerpers en bedrijfshoofden

Procestechnologen 
Beroepsgroepen, volgens SBC '92 (vervolg)

\section{HOGERE TRANSPORTBEROEPEN}

682 Hogere transportberoepen (excl. Technisch)

\section{HOGERE (PARA)MEDISCHE BEROEPEN}

692 Hogere algemene, verzorgende (para)medische beroepen

693 Hogere technisch-(para)medische beroepen

71 HOGERE ADMINISTRATIEVE, COMMERCIËLE, ECONOMISCHE BEROEPEN

\section{Hogere algemeen economische beroepen}

713 Hogere bedrijfskundige beroepen e.d.

714 Hogere administratieve beroepen (automatisering e.d.)

715 Hogere administratieve beroepen (excl. Automatisering)

$716 \quad$ Hogere commerciële beroepen e.d.

721 Hogere technisch-, wiskundig-commerciële, administratieve beroepen

73 HOGERE JURIDISCHE, BESTUURLIJKE, BEVEILIGINGSBEROEPEN

732 Hogere juridische, bestuurlijke beroepen

$742 \quad$ Hogere algemene beveiligingsberoepen

\section{HOGERE TAALKUNDIGE, CULTURELE BEROEPEN}

752 Hogere taalkundige beroepen

753 Hogere bibliotheek- documentatieberoepen

$754 \quad$ Hogere kunstzinnige beroepen

76

762

763

764

77

772

Hogere beroepen in de journalistiek

Hogere sociaal-wetenschappelijke beroepen e.d.

HOGERE VERZORGENDE BEROEPEN

Hogere verzorgende beroepen
Vliegers, scheepskapiteins en leidinggevenden transport

Therapeuten en verpleegkundigen

Medisch analisten

Bedrijfshoofden

Organisatie-adviseurs

Systeemanaliste

Assistent accountants

Commercieel medewerkers

Technisch-bedrijfskundig medewerkers

Juridisch, bestuurlijk medewerkers

Politie-inspecteurs en officieren

Tolken, vertalers en schrijvers

Bibliothecarissen

Kunstenaars

Geestelijk verzorgers

Sociaal-cultureel werkers

Journalisten

Sociaal-wetenschappelijk medewerkers

Afdelingshoofden zorginstelling 
Beroepsgroepen, volgens SBC '92 (vervolg)

78 MANAGERS (HBO WERK- EN DENKNIVEAU) ED.

788 Managers (HBO werk- en denkniveau) e.d.

\section{WETENSCHAPPELIJKE PEDAGOGISCHE BEROEPEN}

Wetenschappelijke pedagogische beroepen (ongeacht specialisatie)

822 Wetenschappelijke onderwijskundige, pedagogische beroepen

825 Docenten exacte, (para)medische, verzorgende vakken $\left(1^{\mathrm{e}} \mathrm{gr}\right.$. en WO)

826 Docenten agrarische, technische, transportvakken $\left(1^{\mathrm{e}} \mathrm{gr}\right.$. en WO

831 Docenten economische, administratieve, juridische vakken $\left(1^{\mathrm{e}} \mathrm{gr}\right.$. en WO

Docenten taalkundige, culturele vakken $\left(1^{\mathrm{e}} \mathrm{gr}\right.$. en WO

834 Docenten sociale, psychologische vakken $\left(1^{\mathrm{e}} \mathrm{gr}\right.$. en WO

\section{WETENSCHAPPELIJKE LANDBOUWKUNDIGE BEROEPEN}

842 Wetenschappelijke landbouwkundige beroepen

85 WETENSCH. WISKUNDIGE, NATUURWETENSCHAPPELIJKE BEROEPEN

851 Wetenschappelijke wiskundige, natuurwetenschappelijke beroepen

\section{IJKE TECHNISCHE BEROEPEN}

861 Wetenschappelijke technische (ongeacht specialisatie), beroepen

862 Wetenschappelijke (weg- en waterbouw-)bouwkundige beroepen e.d.

867 Wetenschappelijke elektrotechnische beroepen

871 Wetenschappelijke materiaalkundige, procestechnische beroepen e.d.

89 WETENSCHAPPELIJKE (PARA)MEDISCHE BEROEPEN ED.

892 Wetenschappelijke (para)medische beroepen (excl. technisch)

893 Wetenschappelijke technisch (para)medische beroepen

91 WETENSCHAPPELIJKE ECONOMISCHE, ADMINISTRATIEVE BEROEPEN ED.

912 Wetenschappelijke algemeen-economische, commerciële beroepen e.d.

913 Wetenschappelijke (technisch-) bedrijfskundige, wiskundig-economische beroepen

$914 \quad$ Wetenschappelijke administratieve beroepen (automatisering e.d.)

915 Wetenschappelijke administratieve beroepen (excl. automatisering
Leidinggevenden

Docent $1^{\mathrm{e}}$ graads zonder specialisatie

Onderwijskundigen en pedagogen

Docenten exacte, medische en verzorgende vakken $\left(1^{\mathrm{e}} \mathrm{gr}\right.$.

Docenten landbouw en techniek $\left(1^{\mathrm{e}} \mathrm{gr}\right.$.)

Docenten economisch-administratieve vakken $\left(1^{\mathrm{e}} \mathrm{gr}\right.$.

Docenten letteren $\left(1^{\mathrm{e}} \mathrm{gr}\right.$ )

Docenten sociale vakken $\left(1^{\mathrm{e}} \mathrm{gr}\right.$.

Landbouwkundigen

Natuurwetenschappers

Werktuigbouwkundigen

(Weg- en water)bouwkundigen

Elektrotechnici

Materiaalkundigen

Artsen

Apothekers

\section{Economen}

Orgnisatiedeskundigen

Informatici

Accountants 


\section{Beroepsgroepen, volgens SBC '92 (vervolg)}

Nr. $\quad$ SBC Beroepsklasse Beroepsgroep (CBS-naam)

Beroepsgroep (ROA-naam)

93 WETENSCHAPPELIJKE JURIDISCHE, BESTUURLIJKE BEROEPEN

932 Wetenschappelijke juridische, bestuurlijke

Juristen

96 WETENSCHAPPELIJKE BEROEPEN M.B.T. GEDRAG EN MAATSCHAPPIJ

Wetenschappelijke theologische beroepen

Wetenschappelijke sociaal-maatschappelijke beroepen

Wetenschappelije journalistieke, talkundige, culturele beroepen

Wetenschappelijke sociaal-wetenschappelijke beroepen

Sociale raadslieden en hoofden personeelszaken

Taalkundigen

Sociaal-wetenschappelijk onderzoekers

MANAGERS (WETENSCHAPPELIJK WERK- EN DENKNIVEAU)

Managers (wetenschappelijk werk- en denkniveau) 


\section{Beknopte Bedrijfsclassificatie SBI '93}

Nr. Bedrijfssector

SBI '93

01000-02999, 05000-05999

15000-16999

24000-25999

27000-36099, 36200-36599, 36700-36999

17000-22999, 26000-26999, 36100-36199, 36600-36699

10000-11999, 14000-14999,

23000-23999, 40000-41999,

45000-45999, 70000-70999

50000-50402, 50500-54999

60000-64999

$65000-67999$

55000-55999, 71000-72999

74000-74999, 90000-90999,

92400-92799, 93000-95999,

73000-73999, 85000-85999,

91000-91999, 92001-92399,

75000-75999, 80000-80999

99000-99500 


\section{Uitgebreide Bedrijfsclassificatie SBI '93}

\begin{tabular}{|c|c|c|}
\hline $\mathrm{Nr}$. & Bedrijfssector & SBI '93 \\
\hline 1. & Tuinbouw & 01120-01199 \\
\hline 2. & Veehouderij & $01200-01599$ \\
\hline 3. & Akkerbouw, bosbouw en visserij & $\begin{array}{l}\text { 00001-01119, 02001-02999, } \\
05000-05999\end{array}$ \\
\hline 4. & Vlees- en visverwerking & $15000-15299$ \\
\hline 5. & Overige voedingsproducten & $15300-15899$ \\
\hline 6. & Drank en tabaksproducten & $15900-16999$ \\
\hline 7. & Basischemie & $24000-24199$ \\
\hline 8. & Eindproducten chemie & $24200-24999$ \\
\hline 9. & Kunststofverwerking & $25000-25999$ \\
\hline 10. & Basismetaal & $27000-27999$ \\
\hline 11. & Metaalproducten & $\begin{array}{l}28000-28999,36000-36099 \\
36200-36599,36700-36999\end{array}$ \\
\hline 12. & Machine-industrie & $29000-29999$ \\
\hline 13. & Elektrotechniek & $30000-33999$ \\
\hline 14. & Transportmiddelen & $34000-35999$ \\
\hline 15. & Textiel & $17000-19999$ \\
\hline 16. & Hout- en bouwmaterialen & $\begin{array}{l}20010-20999,26000-26999 \\
36100-36199,36600-36699\end{array}$ \\
\hline 17. & Papier & $21000-21999$ \\
\hline 18. & Grafische industrie & $22001-22999$ \\
\hline 19. & Energie & $\begin{array}{l}10000-11999,14000-14999 \\
23000-23999,40000-41999\end{array}$ \\
\hline 20. & Bouw & $45000-45999$ \\
\hline 21. & Exploitatie van onroerend goed & $70000-70999$ \\
\hline 22. & Handel en reparatie & $50000-50402,50500-52999$ \\
\hline 23. & Scheep- en luchtvaart & $61000-62999$ \\
\hline 24. & Weg- en railvervoer & $60000-60999,63000-63999$ \\
\hline 25. & Communicatie & $64000-64999$ \\
\hline 26. & Bankwezen & $65000-65999,67000-67199$ \\
\hline 27. & Verzekeringswezen & $66000-66999,67200-67999$ \\
\hline 28. & Horeca & $55000-55999$ \\
\hline 29. & Zakelijke dienstverlening & $71000-72999,74000-74999$ \\
\hline 30. & Overige commerciële dienstverlening & $\begin{array}{l}90000-90999,92400-92799 \\
93000-95999\end{array}$ \\
\hline 31. & Gezondheidszorg & $85000-85999$ \\
\hline 32. & Overige kwartaire diensten & $\begin{array}{l}\text { 73000-73999, } 91000-91999 \\
92001-92399\end{array}$ \\
\hline 33. & Onderwijs & $80000-80999$ \\
\hline 34. & Overheid & $75000-75999,99000-99500$ \\
\hline
\end{tabular}




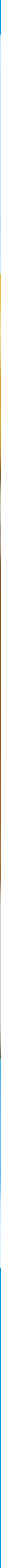

